UNIVERSIDADE DE SÃO PAULO

FACULDADE DE FILOSOFIA, LETRAS E CIÊNCIAS HUMANAS DEPARTAMENTO DE LETRAS CLÁSSICAS E VERNÁCULAS PROGRAMA DE PÓS-GRADUAÇÃO EM LETRAS CLÁSSICAS

ROBERTO FERNANDES DE NARDI

\title{
AS TETRALOGIAS DE ANTIFONTE: TRADUÇÃO E COMENTÁRIOS
}

Versão Corrigida

São Paulo

2015 
UNIVERSIDADE DE SÃO PAULO

FACULDADE DE FILOSOFIA, LETRAS E CIÊNCIAS HUMANAS

DEPARTAMENTO DE LETRAS CLÁSSICAS E VERNÁCULAS

PROGRAMA DE PÓS-GRADUAÇÃO EM LETRAS CLÁSSICAS

\section{AS TETRALOGIAS DE ANTIFONTE: \\ TRADUÇÃO E COMENTÁRIOS}

Versão Corrigida

ROBERTO FERNANDES DE NARDI

Dissertação apresentada ao Programa de Pós-

Graduação em Letras Clássicas do Departamento de Letras Clássicas e Vernáculas da Faculdade de Filosofia, Letras e Ciências Humanas da Universidade de São Paulo, para obtenção do título de mestre em Letras Clássicas.

Orientador: Prof. Dr. Adriano Machado Ribeiro

São Paulo

2015 


\section{AGRADECIMENTOS}

Ao Prof. Dr. Adriano Machado Ribeiro, pela orientação desde os tempos de Iniciação Científica.

Ao Prof. Dr. Daniel Rossi Nunes Lopes (FFLCH/USP) e ao Prof. Dr. Marcos Martinho dos Santos (FFLCH/USP), que compuseram a banca de qualificação desta dissertação, pelos comentários e opiniões.

Ao Prof. Dr. Marcelo Pimenta Marques (FAFICH/UFMG) e à Profa. Dra. Josiane Teixeira Martinez (EFLCH/UNIFESP), que compuseram a banca de defesa da dissertação, pelas observações e sugestões.

À CAPES, pela bolsa concedida.

A Laura, pelo apoio e a quem dedico parte desta dissertação. 


\title{
RESUMO
}

Esta dissertação traduz e comenta as Tetralogias de Antifonte. Trata-se dos três discursos que lidam com casos hipotéticos de homicídio compostos na segunda metade do século V a.C. e que são caracterizados como exercícios argumentativos. Para isso, tal pesquisa foi dividida em três partes: (i) um capítulo com a exposição de algumas informações acerca do autor e da obra; (ii) a apresentação de uma edição atualizada seguida de uma tradução completa dos três discursos; e (iii) os comentários referentes a cada um deles.

Palavras-chave: Antifonte; Tetralogias; exercícios argumentativos.

\begin{abstract}
This study aimed to translate and comment the Tetralogies of Antiphon, which consists of three speeches of hypothetical homicide cases. The speeches were written in second half of the fifth century BC. They consist of exercices in argumentation. The study was divided into three parts: (i) the chapter presenting the author and his work; (ii) an up-to-date edition and a complete translation of the three speeches; and (iii) the commentaries concerning each one of them.
\end{abstract}

Key-words: Antiphon; Tetralogies; argumentative exercices. 


\section{SUMÁRIO}

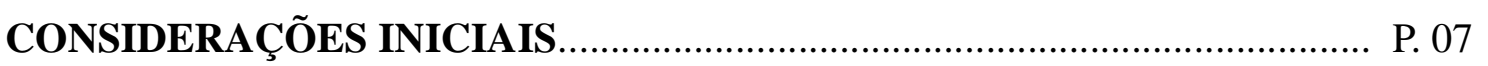

1. SOBRE AS TETRALOGIAS DE ANTIFONTE..................................... p. 10

1.1 Sobre a identidade de Antifonte ..................................................... p. 11

1.2 $\mathrm{O}$ ordenamento jurídico em casos de homicídio na Atenas do século $\mathrm{V}$

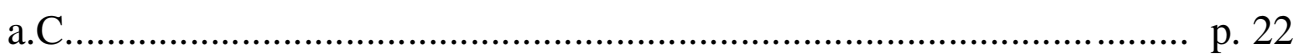

1.3 As antilogias e as Tetralogias.............................................................. p. 37

1.4 Sobre a elocução das Tetralogias........................................................... p. 43

1.5 Sobre a edição grega................................................................... p. 56

2. TEXTOS, TRADUÇÕES E NOTAS DAS TETRALOGIAS ....................... p. 58

2.1 Texto, tradução e notas da Tetralogia I................................................. p. 58

2.2 Texto, tradução e notas da Tetralogia II............................................... p. 79

2.3 Texto, tradução e notas da Tetralogia III............................................ p. 96

3. COMENTÁRIOS DAS TETRALOGIAS ............................................... p. 111

3.1 Comentário da Tetralogia I............................................................ p. 111

3.1.1 Da disposição dos discursos................................................... p. 112

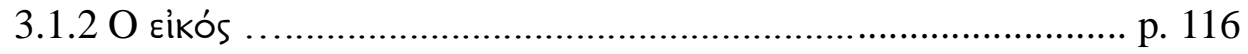

3.1.3 O miasma …...................................................................... p. 133

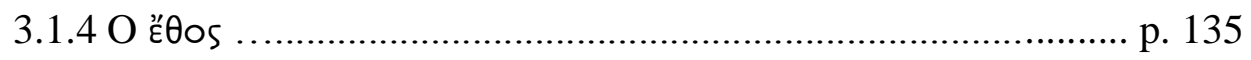

3.2 Comentário da Tetralogia II......................................................... p. 136

3.2.1 Da disposição dos discursos ........................................... p. 136

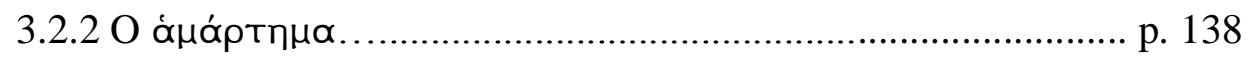

3.2.3 A intenção, a causa e a responsabilidade ............................. p. 143

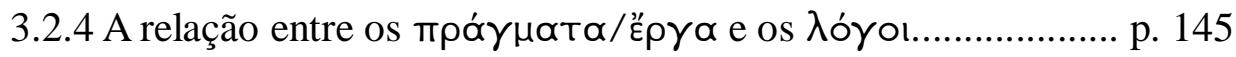

3.2.5 O miasma ..................................................................... p. 154 
3.3 Comentário da Tetralogia III............................................................ p. 156

3.3.1 Da disposição dos discursos ................................................. p. 157

3.3.2 A intenção, a causa e a responsabilidade................................. p. 159

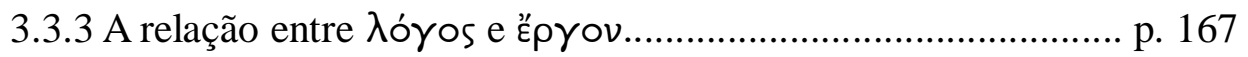

3.3.4 A relação entre vómos e qúoı (............................................... p. 168

3.3.5 O miasma …................................................................ p. 175

REFERÊNCIAS BIBLIOGRÁFICAS.................................................. p. 177 


\section{CONSIDERAÇÕES INICIAIS}

Das obras atribuídas a Antifonte, as Tetralogias têm sua importância atestada por estarem entre as primeiras composições em prosa ática, por documentarem a evolução da prática argumentativa em Atenas, e por ilustrarem, mediante uma série de exemplos ou modelos de discursos, exercícios argumentativos do século V a.C. Tal obra fornece uma demonstração de argumentos opostos em três casos hipotéticos de homicídio.

O propósito das Tetralogias, contudo, não é claro. Frequentemente são tratadas como composições voltadas para a prática e demonstração, cuja audiência seria um público de oradores ou futuros oradores ${ }^{1}$. Mas também poderiam ser vistas, sobretudo, como especulações acerca de assuntos importantes da segunda metade do século $\mathrm{V}$ a.C. e, nesse sentido, seriam direcionadas a uma audiência mais específica, cidadãos cultos da pólis, da qual bem poderiam haver oradores e futuros oradores ${ }^{2}$. Ainda que não se descarte a utilidade desses exercícios para uma ampla variedade de situações relacionadas à vida pública, é difícil acreditar que as Tetralogias - quanto aos seus argumentos - tenham sido úteis na construção de discursos para serem apresentados na assembleia e, principalmente, nos tribunais, e tido um valor prático no sentido de fornecer um apoio no planejamento de um discurso forense ou servir como modelo de defesa ou de acusação em um caso efetivo. Isso porque Antifonte, nas Tetralogias, embora reproduza a estrutura e alguns procedimentos dos discursos forenses, modela um cenário de tribunal ou um mundo forense hipotético, com situações específicas - e

\footnotetext{
${ }^{1}$ Dobson acredita que as Tetralogias estão situadas no limite entre a prática e a teoria e que seriam exercícios compostos para casos imaginários de homicídio. Esses modelos de discursos, segundo o autor, dariam uma clara ideia das linhas sobre as quais cada um dos lados em uma disputa judicial deveria sustentar em um tribunal (DOBSON, 1919, s.p.). Kennedy defende que as Tetralogias foram compostas para servirem como modelos de técnicas eficazes de oratória judicial e que são exemplos de uma forma de instrução retórica que floresceu em Atenas. Questiona, contudo, se o professor simplesmente dava exemplos de tratamento eficaz que seu aluno memorizaria ou imitaria, ou se acompanharia seus discursos-modelos com comentários críticos como um professor moderno seria apto a fazer (KENNEDY, 1980, pp. 26-8). Thomas Cole sugere que elas são um antigo texto de prática e demonstração, um modelo de discurso dedicado a um tipo de assunto que provavelmente seria utilizado em discussões no âmbito político e judicial, e que teria uma grande variedade de utilidades. (COLE, 1991, p. 75).

${ }^{2}$ Louis Gernet entende que as Tetralogias são exercícios de escola compostos por um sofista, pois apresentam algumas características (concepção, ordem, detalhes das lições e dos temas) bem conhecidas da "retórica dos sofistas" (GERNET, 1954, p.16). Carawan ressalta o valor prático (modelos de discursos compostos para a demonstração prática) e teórico (especulações abstratas sobre alguns assuntos importantes) das Tetralogias (CARAWAN, 1993, p. 235). Gagarin diz que elas apresentam casos fictícios, construídos por um autor de tal modo a demonstrar ou ensaiar argumentos que ele estaria interessado em explorar (GAGARIN, 1994, p. 52). G. R. E. Lloyd sugere que as Tetralogias são discursos artificiais sobre casos imaginários de tribunal que serviriam como modelos a serem imitados em ocasiões da vida real (LLOYD, 1999, p. 80).
} 
em grande medida divergentes da prática do direito ateniense do século V a.C. - que lhe permitem elaborar argumentos e explorar assuntos de seu interesse, aparentemente para um público seleto, os atenienses cultos.

Dada, sobretudo, a grande complexidade de elocução das Tetralogias e os tipos de argumentos nelas trabalhados, reforça-se a tese de que sejam textos para a prática de uma habilidade argumentativa de seu autor e aventa-se a possibilidade de terem sido compostas para a leitura, o estudo, a discussão e, talvez, para a imitação, caracterizandose, desse modo, como textos de importante valor como prática pedagógica e discursiva.

Dito isso, a presente dissertação de mestrado visa analisar as Tetralogias a partir de sua tradução. Tal estudo basicamente se desenvolve em três capítulos: (i) exposição de algumas informações que julgamos relevantes acerca do autor e da obra; (ii) tradução das Tetralogias a partir de uma edição mais atualizada; e (iii) comentários referentes a cada um dos discursos que a constituem.

O primeiro capítulo desta pesquisa divide-se em cinco partes e tem caráter introdutório. Na primeira parte, mais específica, discorre-se brevemente acerca da questão tradicional que envolve a identidade de Antifonte, a saber: se há ou não a distinção entre um, dois ou mais autores homônimos com base em testemunhos antigos e em divergências tanto acerca das teses apresentadas nos textos, quanto aos aspectos lexicais e de elocução presentes nas obras atribuídas a este único Antifonte. As demais partes são mais técnicas e voltadas para um melhor entendimento da obra. A segunda lida com o ordenamento jurídico nos casos de homicídio na Atenas do século $\mathrm{V}$ a.C., haja vista o caráter forense, ainda que hipotético, das Tetralogias e o assunto abordado em cada uma delas. Para isso, pretende-se apresentar de modo resumido alguns aspectos do sistema legal ateniense (organização dos tribunais e procedimentos dos litigantes) de modo a compreender os discursos aqui traduzidos e comentados. A terceira parte tem como pressuposto que tais exercícios argumentativos são compostos de modo a constituírem pares de discursos opostos, antilogias, e que ilustram exemplarmente uma prática argumentativa comum no período. A quarta parte faz um levantamento dos elementos de elocução utilizados por Antifonte para a elaboração da sua prosa. E, finalmente, a quinta parte indica a edição que serviu de base para a tradução e os critérios das notas.

Os dois últimos capítulos tratam do objetivo principal da pesquisa: a tradução e os comentários acerca desta. O segundo capítulo traz a tradução das três Tetralogias. 
Para isso, foi adotado o texto estabelecido por Michael Gagarin para a coleção Cambridge Greek and Latin Classics.

O terceiro capítulo divide-se em três partes e restringe-se aos comentários das traduções, preocupando-se em analisar a disposição e os argumentos dos discursos. A primeira parte comenta a Tetralogia I, discurso que lida com um caso em que os fatos estão em disputa; estas circunstâncias possibilitam a Antifonte desenvolver, sobretudo, argumentos baseados no Eíkós, quase como um tópico que serve de base para a construção dos discursos no século V a.C. A segunda parte visa comentar a Tetralogia II, em que os fatos são claros mas a causa e a responsabilidade estão em questão; tal cenário possibilita a Antifonte elaborar uma interessante discussão envolvendo 入óyos e Épyov, um tópico relevante do período. A terceira parte lida com a Tetralogia III e analisa um cenário semelhante à da Tetralogia II, em que os fatos não estão em disputa, e que ecoa alguns aspectos desenvolvidos nos dois primeiros discursos, mas inserindo outros tópicos do pensamento e da argumentação do século $\mathrm{V}$ a.C. tal como a relação vónos e qúois. 


\section{SOBRE AS TETRALOGIAS DE ANTIFONTE}

\subsection{Sobre a identidade de Antifonte}

Antifonte nasceu e morreu em Atenas no século V a.C. Proveniente de Ramnunte, um dêmos de Atenas, teria nascido por volta de 480 a.C.. Foi um dos líderes de um grupo de aristocratas denominado os "Quatrocentos”, que, por meio de um golpe, instaurou em 411 a.C. um curto governo oligárquico e pró-espartano, substituindo o regime democrático de então. Esse novo governo logo chegou ao fim. Quase todos os seus líderes foram para o exílio, mas Antifonte permaneceu em Atenas onde foi julgado, condenado e executado por traição em 411 a.C.

Os eventos em torno da instauração e queda do governo dos "Quatrocentos" são descritos por Tucídides no livro 8 da Historia da Guerra do Peloponeso. Durante esse relato, um pequeno retrato de Antifonte é fornecido:

8.68. O autor daquelas propostas ${ }^{3}$ foi Pisandro, que em tudo era declaradamente o adversário mais fervoroso da democracia, mas quem planejou todo o esquema e o levou àquele resultado, tendo se ocupado do assunto durante muito tempo, foi Antifonte, um homem que, entre os atenienses de seu tempo, não era inferior a nenhum outro em qualidade (ápєtń), e foi o melhor em conceber e dizer aquilo que pensava. Embora não comparecesse à assembleia nem participasse de qualquer debate público, ao menos voluntariamente, Antifonte era visto com desconfiança pela multidão por causa de sua extrema habilidade em discursar ( $\delta \varepsilon ı$ ótms). Ninguém, contudo, era mais capaz do que ele de prestar auxílio àqueles que se envolviam em uma disputa, quer nos tribunais, quer na assembleia, quem quer que lhe pedisse conselhos. Quando mais tarde os "Quatrocentos" foram depostos pelo povo e estavam sendo tratados rudemente por eles e Antifonte foi acusado por conta disso (porque contribuiu para instaurar o regime oligárquico), pareceu-me ter feito a melhor defesa em um caso capital ${ }^{4}$.

\footnotetext{
${ }^{3}$ Tucídides se refere às propostas apresentadas na assembleia em Colonos que, entre outras coisas, defendia a extinção dos poderes de todos os magistrados em exercício, a abolição dos salários para os cargos públicos e a escolha de cinco homens para comporem o Conselho pritaneu, que, por sua vez, escolheriam cem cidadãos atenienses; cada um desses cidadãos escolheria outros três, constituindo-se, assim, os quatrocentos que se reuniriam no Conselho e governariam com plenos poderes.

${ }^{4}$ Tradução minha.
} 
Ainda que sucinta, depreende-se dessa passagem algumas informações específicas sobre Antifonte. A descrição, primeiro, refere-se a um homem com qualidades, notável por sua inteligência e habilidade em falar, que gerava desconfiança na multidão. Certamente essa primeira descrição poderia facilmente associar Antifonte a outros pensadores do período designados, posteriormente e talvez imprecisamente, como "sofistas", 5 , visto que tradicionalmente a habilidade em falar, ou o falar bem

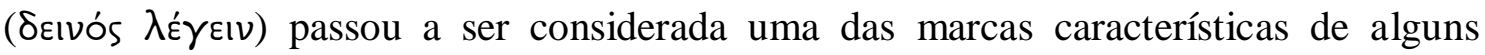
pensadores do século V a.C. chamados de "sofistas"6. A reputação na habilidade em

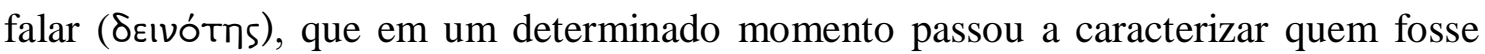
"perito em discurso e argumentação" (GUTHRIE, 1995, p. 35), poderia facilmente ser vista com suspeita por um público sem essa perícia, que se tornou uma qualificação depreciativa $^{7}$, embora inicialmente não fosse. Curiosamente, mesmo não comparecendo nos tribunais e na assembleia, supondo-se que Antifonte não expunha frequentemente a sua habilidade em público, ainda assim era visto com desconfiança em razão disso.

A descrição também reforça a competência de Antifonte em prestar auxílios àqueles que necessitavam de conselhos em assuntos referentes ao tribunal e à assembleia. Nada acerca de uma atividade ou ofício de escritor de discursos (logógrafo) é explicitado no parágrafo. De fato, Antifonte é considerado pela tradição ${ }^{8}$ o primeiro a deixar discursos escritos e o primeiro logógrafo. Mas, além de Tucídides nada declarar nessa passagem, é difícil saber se Antifonte foi realmente o primeiro a escrever e a compor discursos para outros apresentarem como se fossem seus, visto que, como lembra Edwards ${ }^{9}$, essa tradição pode ser apenas uma conjectura, originada da ausência de discursos compostos antes dele. Pode-se deduzir dessa passagem apenas que, mesmo não discursando na assembleia nem no tribunal, ele teria se interessado por assuntos

\footnotetext{
${ }^{5}$ A designação "Sofista" seria imprecisa fundamentalmente por não haver um grupo particular de indivíduos com um pensamento comum e com atividades comuns, mas sim pensadores (Protágoras, Górgias, Hípias, Pródico, Trasímaco, Crítias, Antifonte etc.) com uma variedade de teorias, práticas, interesses e ideologias, e que seria insuficiente, para uma unificação, o interesse comum entre eles pelo $\lambda$ óyos, pela persuasão e pela educação, como sugere Schiappa (SCHIAPPA, 1999, p. 56).

${ }^{6}$ No Protágoras de Platão (312 c-d), por exemplo, ao ser indagado por Sócrates sobre o que consistiria a sabedoria dos sofistas, Hipócrates diz primeiro que um sofista "é alguém cheio de sabedoria" e, acrescenta, após nova indagação de Sócrates, que sua sabedoria consiste em "ensinar a falar bem". Nesse

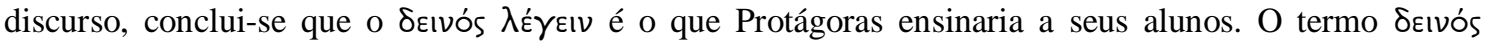
etimologicamente carregaria o sentido de qualquer coisa "terrível" ou "temerosa", sugerindo "algo estranho, incompreensível, misterioso" (GUTHRIE, 1995, p. 35). Curiosamente, na Apologia de Sócrates, em 17b, Sócrates é acusado, dentre outras coisas, de ser hábil em falar.

${ }^{7}$ Cf. Aristófanes, As Nuvens (vv. 331; 360; 1111)

${ }^{8}$ Cf. Pseudo-Plutarco, Vidas dos dez oradores (1).

${ }^{9}$ EDWARDS, 2000, p. 238
} 
públicos e assuntos legais, tendo em vista que prestava assistência àqueles que se envolviam em disputas públicas. No mais, nada é dito sobre o fato de escrever discursos para outros memorizarem e apresentarem em tribunais. Sobre a informação de Tucídides de que Antifonte não participava diretamente da vida pública, sabe-se que o único discurso de que se tem notícia que o próprio Antifonte pronunciou em um tribunal foi justamente o Sobre a Revolução de 411 a.C., sua defesa contra a acusação pública de traição, que na opinião de Tucídides foi a melhor pronunciada até então. Ainda que a qualidade desse discurso seja ressaltada, Antifonte não saiu vitorioso, sendo condenado e executado em 411 a.C. O retrato apresentado por Tucídides, portanto, é breve e em nenhum momento Antifonte é definido com a alcunha de "orador", "sofista" ou mesmo "escritor de discursos".

Informações adicionais sobre a vida de Antifonte também poderiam ser inferidas das obras existentes do autor, completas ou em estado fragmentário. Um dos três discursos forenses, Sobre o assassinato de Herodes (5), provavelmente do período entre 420 a.C. e 411 a.C., apresenta a defesa de um cidadão de Mitilene. E além dele, Antifonte compôs discursos para os Líndios (frgs. 25-33 Thalheim) e Samotrácios (frgs. 49-56 Thalheim) a respeito de seus tributos. Isso poderia indicar que Antifonte escreveu discursos para outras cidades gregas, não apenas para Atenas. Logo, teria viajado e tido conexões mais amplas, como sugere Gagarin ${ }^{10}$, sendo possivelmente simpático às causas de aliados atenienses. As Tetralogias, por sua vez, caracterizadas como exercícios argumentativos elaborados por volta de 430 a.C., poderiam sinalizar um autor interessado nos tópicos importantes do pensamento e da argumentação do período.

Com relação às obras atribuídas a Antifonte, sabe-se por Pseudo-Plutarco, na Vida dos Dez Oradores, que, no século I d.C., sessenta títulos formavam um corpus dos trabalhos atribuídos ao autor, dos quais vinte e cinco foram considerados apócrifos por Cecílio. Os seis discursos completos que sobreviveram provavelmente representavam os primeiros seis discursos em um antigo corpus. Três discursos (1, 5 e 6), cuja autenticidade não é colocada em dúvida, foram escritos para casos de tribunais - Contra a madrasta, por envenenamento (1), Sobre o assassinato de Herodes (5) e Sobre o

\footnotetext{
10 "Vários discursos perdidos foram escritos para outras cidades gregas e um discurso que sobreviveu (Ant. 5) diz respeito à defesa de um cidadão de Mitilene; isso sugere que Antifonte viajou e teve conexões mais amplas" (GAGARIN, 1997, p. 4).
} 
Coreuta (6) - e três formam as Tetralogias $\left(2,3\right.$ e 4) ${ }^{11}$. Atualmente temos vinte títulos de outros trabalhos atribuídos a Antifonte, dentre eles o fragmento do discurso de defesa de Antifonte Sobre a Revolução e os fragmentos dos três trabalhos que o aproximam de temas considerados sofísticos: Sobre a Verdade, Sobre a Concórdia e Político.

Além de Tucídides, a outra evidência contemporânea da vida de Antifonte está contida nas Memoráveis (1.6.1-15) de Xenofonte. Em uma passagem, Xenofonte mostra Sócrates dialogando com um Antifonte denominado "sofista" (Tòv бoфıotñv). Nessa discussão fictícia, Antifonte é retratado como querendo tomar os discípulos de Sócrates, que estavam presentes no momento do diálogo. Em três momentos dessa conversa, Antifonte explicitamente ressalta que a pobreza de Sócrates não seria um bom modelo de imitação para seus discípulos; que o ensino gratuito de Sócrates poderia ser reflexo de um ensino sem valor; e que Sócrates não poderia ensinar aos outros a arte da política se ele mesmo não se engajava na política que dizia conhecer. Embora Xenofonte não deixe explícito, esses três momentos poderiam sugerir, respectivamente, que Antifonte, pelo modo como argumenta, possuiria a riqueza que falta a Sócrates; que cobraria pelo ensino; e que se envolveria com política.

No diálogo fictício de Xenofonte, esse retrato de Antifonte não seria, de todo modo, inconsistente com o relato de Tucídides e mesmo com a única menção de Platão a Antifonte, o ramnúsio, em Menexeno (236 a) como alguém que ensina retórica (’́nторıкń). No retrato de Xenofonte, insinua-se uma participação, ainda que indiretamente, na vida pública; no platônico, embora "professor de retórica" seja uma identificação problemática, como se verá, parece estar subtendido não somente uma

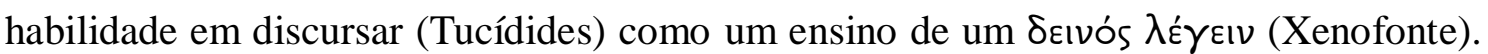
Além do mais, se o epíteto ooфıotńs pode favorecer a identificação de um "sofista", evidências antigas sugerem que o termo ooфıotńs era utilizado amplamente nos séculos V e IV a.C. e, antes de Platão, podia ser empregado como quase sinônimo de ooфós, como atesta Heródoto no livro I das Histórias, ao mencionar "Pitágoras, Sólon e os

\footnotetext{
${ }^{11}$ Dover defende, a partir de evidências linguísticas, que dois pontos firmes na cronologia dos discursos de Antifonte são a data do Sobre o Coreuta (6) em 419/8 a.C. e a defesa de Antifonte Sobre a Revolução em 411 a.C. O discurso Sobre o assassinato de Herodes (5) teria sido composto entre esses dois. O discurso Contra a madrasta por envenenamento (1) é visto por alguns como um discurso mais antigo de Antifonte, mas Dover não está certo disso, acreditando que foi escrito depois de Sobre o Coreuta (6) e antes de Sobre o assassinato de Herodes (5). E quanto às Tetralogias (2,3 e 4), não há concordância sobre sua data, mas a presença do que ele denomina como fenômenos linguísticos ausentes nos discursos de tribunal atestariam talvez a antiguidade dos discursos hipotéticos de Antifonte. (DOVER, 1950, pp. 44$60)$.
} 
fundadores do culto dionisíaco" (GUTHRIE, 1995, p. 32). Assim, não seria estranho que oopıotńs fosse aplicado a Antifonte como foi aplicado por Ésquines a Sócrates (1.173), nem se tal designação fosse utilizada para poetas, oradores e logógrafos ${ }^{12}$, como de fato o era ${ }^{13}$. Com efeito, não haveria evidência para sustentar que o Antifonte "sofista", mencionado por Xenofonte, não possa ser o mesmo Antifonte de Ramnunte. Agrega-se a este, apenas uma cobrança pelo ensino e uma riqueza ${ }^{14}$. Curiosamente, com exceção de Pródico, que é mencionado com o epíteto de “o sábio" (ö ooфós) (2.1.21), todos os pensadores tradicionalmente denominados por "sofistas" citados nas Memoráveis são identificados geralmente pela sua cidade de origem. Gagarin sugere três hipóteses para essa identificação de Antifonte como "sofista" ${ }^{15}$ : ou os assuntos tratados por Antifonte são assuntos naturalmente tratados por Sócrates com os sofistas; ou a designação "sofista" pode ser uma tentativa de Xenofonte de prejudicar, perante seus leitores, a imagem de Antifonte; ou serviria para distinguir esse Antifonte de Ramnunte de outros de mesmo nome, visto que "Antifonte" seria um nome comum na Grécia.

Quando outro Antifonte, que não o ramnúsio, é mencionado em fontes antigas, geralmente especifica-se com algum epíteto esse outro autor, como o faz Aristóteles na Retórica (II 6, 1385a8-13) ao designar um Antifonte, “o poeta”, morto por Dionísio no século IV a.C. Entretanto, ao tratar do Antifonte de Ramnunte na Constituição Ateniense $(32,1-2)^{16}$ e na Ética a Eudemo (III 5, 1232b 4-10), utiliza apenas "Antifonte", sem especificações adicionais ${ }^{17}$. Ademais, Aristóteles designa por "Antifonte", também sem outras especificações, o Antifonte que Gagarin acredita ser o de Ramnunte ${ }^{18}$, que trata do problema da quadratura do círculo pelo método da exaustão (Física 185a e DK

\footnotetext{
${ }^{12}$ GAGARIN, 2002, p.9

${ }^{13}$ Schiappa destaca os estudos de Kerferd (The First Sophists, 1950) e Lloyd (The Revolution of Wisdom, 1987) para reforçar que a denominação "sofista" era aplicada a uma grande variedade de pessoas (Prometeu, Homero, Hesíodo, Sólon, Tales, Pitágoras, Anaxágoras, Empédocles, Zenão, Platão, Sócrates e Isócrates) que se ocupavam de atividades díspares, incluindo a de poetas, músicos e rapsodos, adivinhos e videntes, e uma variedade de "homens sábios", como filósofos, matemáticos e políticos. (SCHIAPPA, 1999, p.51)

${ }^{14}$ A condição de bem nascido de Antifonte também será lembrada em Constituição Ateniense (32.1-2) de Aristóteles.

${ }^{15}$ GAGARIN, 2002, p.42

16 Trabalho atribuído a Aristóteles, talvez escrito por algum aluno seu, em que é possível encontrar informações relevantes sobre os sistemas legal e político da Atenas clássica.

${ }^{17} \mathrm{Na}$ Constituição Ateniense (32.1-2), por exemplo, na parte reservada aos "Quatrocentos", Aristóteles menciona que os maiores instigadores dessa oligarquia foram Pisandro, Antifonte e Teramenes, que eram bem nascidos e tinham a reputação de homens inteligentes e de julgamento justo. Essas informações não contradizem as apresentadas por Tucídides.

${ }^{18}$ ANTIPHON, 1997, p.6
} 
87B13), e que teorizou sobre a natureza das coisas, dedicando-se a problemas físicos e astronômicos (Física 193a e fragmento B8, 26, 28, 32).

Outros autores, como Demóstenes (18.132) e Dinarco (1.63), também mencionam um Antifonte que foi executado durante a luta contra Filipe da Macedônia. Porém, o contexto deixa claro que não se trata do ramnúsio. O mesmo ocorre com Xenofonte, na Helênica (2.3.40), quando menciona o Antifonte assassinado pelos “Trinta" em 404/403.

Assim, com exceção de Xenofonte, nas Memoráveis, que adicionou o epíteto, as demais fontes contemporâneas, quando mencionam um Antifonte do período clássico, ora é o poeta, designado como tal ou pelo contexto ou, ainda, acrescentando o título de uma de suas peças depois do nome, ora é um Antifonte sem uma designação especial, apenas "Antifonte". Se a identificação do autor como oopıotŕs em seu sentido amplo de бoфós seria condizente com os retratos de Tucídides e de Aristóteles, e mais apropriado para descrever alguém como Antifonte, a identificação do autor como “orador", não o seria, pois, durante esse período, a palavra "orador" ( utilizada apenas para cidadãos que apresentassem discursos em público, para aqueles que tomavam a palavra no tribunal ou na assembleia, não comportando o sentido encontrado posteriormente em Górgias (449a3), de quem possuiria o conhecimento técnico de retórica e seria capaz de ensiná-la a outros. Se Antifonte não pode ser

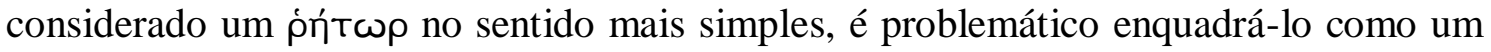
ṕńtwp no sentido platônico, pois tal sentido implica o ensino de uma arte conceitualizada ou um domínio específico de teorização. Se ooфıotńs condiz com o

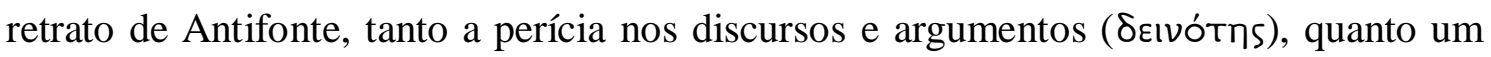

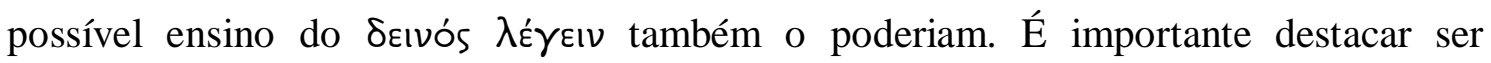
bastante difícil, como observa Gagarin ${ }^{19}$, que alguém empregasse um termo como бoфıoтńs para distinguir um pensador importante da Atenas do século V a.C., chamado Antifonte, de um homônimo do mesmo período e também de Atenas, descrito por Tucídides. Com efeito, a partir dessas poucas referências, não haveria uma evidência muito forte para se concluir que não sejam a mesma pessoa o Antifonte "Tòv бoфıotŕv" de Xenofonte (um ooфós), o Antifonte de Platão (não um ṕńtwp no sentido platônico,

\footnotetext{
19 "Portanto, parece impossível que Xenofonte ou qualquer outra pessoa no período pudesse usar бoфıotńs para distinguir um intelectual do século V a.C. chamado Antifonte do logógrafo Antifonte descrito por Tucídides" (ANTIPHON, 1997, p. 6).
} 


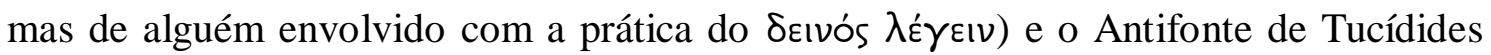

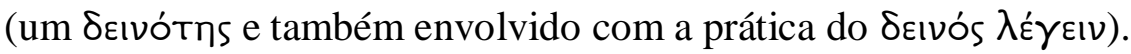

Ainda na antiguidade, gerou-se, no entanto, uma controvérsia envolvendo a identidade do autor: o Antifonte de Ramnunte, tratado equivocadamente pela alcunha de "orador" por causa da composição de discursos de tribunal, seria o mesmo que escreveu os textos considerados "sofísticos" (Sobre a Verdade, Sobre a Concórdia e Político) e identificado como um "sofista"? A origem disso se deve principalmente ao acréscimo da especificação de Xenofonte ao nome do autor, em comparação com a ausência de uma em Tucídides. A discussão remonta a Hermógenes (século II d. C.), o primeiro comentador de que temos notícia, como fonte direta, a distinguir dois Antifontes. Em Sobre os gêneros [de composição literária] (De Ideis 2.11 [A.2 DK/ A.2 U/ T2 P]), alertando para o fato de que o gramático Dídimo (século I a.C.) já o havia feito com base na diferença de elocução e de assunto das obras, Hermógenes defendeu também a distinção entre um Antifonte orador, "cujos discursos tratam de homicídio ou são do gênero deliberativo ou semelhantes a esses" (ANTIFONTE, 2008, p.7) e um Antifonte "dito adivinho e intérprete de sonhos" (Ibid., 7), autor de Sobre a Verdade, Sobre a Concórdia e o Político. Embora deixe claro que ambos argumentam como sofistas (oï

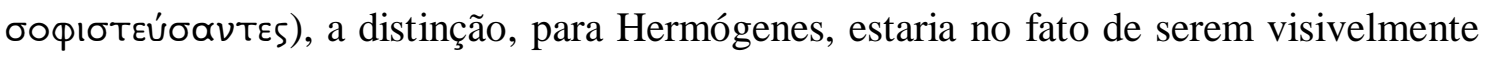

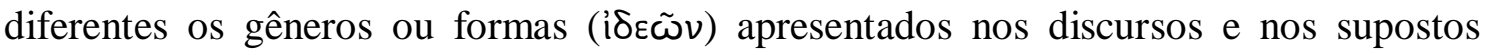
tratados. Mas, por causa da informação presente em Menexeno de Platão, "e de outros" (Ibid., p. 7), Hermógenes não está tão convencido de tal separação, podendo mesmo ter havido um só Antifonte, que utilizou gêneros diferentes nessas obras.

Como observado por Gagarin ${ }^{20}$, essa visão dos gêneros ou das formas diferentes entre os trabalhos de "orador" e de "sofista", que excluiriam um único autor, em momento algum aparece difundida na antiguidade. Muito pelo contrário, os trabalhos eram inseridos em um mesmo corpus e eram atribuídos simplesmente a um "Antifonte". Entretanto, a separação hoje cristalizada teria sido operada sobre as listas de obras fornecidas por Hermógenes. No mais, as várias facetas de Antifonte, que se depreendem dos retratos mencionados acima, poderiam de fato sugerir mais de um autor de mesmo nome e comentadores posteriores passaram a se referir a Antifonte enfatizando uma ou várias de suas atividades. Àquelas indicadas por Tucídides, Xenofonte, Platão e

\footnotetext{
${ }^{20}$ Gagarin alerta para o fato de não ter havido na antiguidade uma separação entre dois autores chamados Antifonte e que os trabalhos considerados retóricos e sofísticos, segundo ele, estariam em um mesmo corpus atribuído simplesmente a um Antifonte (ANTIPHON, 1997, p.5).
} 
Aristóteles, acrescentaram-se as atividades de poeta, seja trágico, seja épico, provavelmente de outro Antifonte, e a de adivinho e intérprete de sonhos.

Pseudo-Plutarco, por exemplo, na Vida dos Dez Oradores (1), ao lidar com um Antifonte - nascido no dêmos de Ramnunte, filho de Sófilo - atribui a ele atividades díspares como a elaboração de tragédias e a composição de uma Arte de Não Sofrer, que consistiria em uma técnica de defesa contra a dor "como existe para os doentes a terapia dos médicos" (ANTIFONTE, 2008, p. 35). Ademais, esse Antifonte, conforme retratado por Pseudo-Plutarco, hesitou em se dedicar à política, divergiu de Sócrates em um debate, e escreveu discursos para cidadãos que os encomendavam. Misturam-se, assim, informações sobre o Antifonte (de Ramnunte) condenado e executado em 411 a.C. com outro Antifonte (o poeta) executado pelos Trinta no século IV a.C. Mas, em última instância, o Antifonte de Tucídides e de Xenofonte é apresentado por Pseudo-Plutarco como a mesma pessoa, desempenhando, porém, várias outras atividades. Em conformidade com essa visão, o Suda (léxico 1, 245, 21-28) oferece uma passagem que apresenta um Antifonte exercendo atividades múltiplas: "Antifonte, ateniense, adivinho, poeta épico e sofista. Era também chamado de 'cozinheiro de discursos"' (Ibid., p. 29), além de intérprete de sonhos e autor de uma obra intitulada Acerca da Interpretação dos Sonhos.

Outros testemunhos seguem a mesma tendência. O de Diógenes Laércio (2.46), por exemplo, que evoca o que diz Aristóteles no livro III da Poética, parece confirmar Xenofonte, nas Memoráveis, ao reforçar certa rivalidade de Antifonte com Sócrates. Diógenes Laércio, contudo, designa-o como "o adivinho" (ó тератобкóтоos). Uma fonte anônima, em Vida de Antifonte (5-7), descreve um Antifonte distante da política e amante do dinheiro, que, em Corinto, criou um estabelecimento em que dava conselhos aos que sofriam de tristeza. Não obtendo muito dinheiro, passou a compor tragédias. Mais tarde, passou a se dedicar à retórica. Filóstrato, em Vidas dos Sofistas (1.15), descreve um Antifonte eloquente, "altamente persuasivo" (Ibid., p. 39), autor de uma técnica de defesa contra a dor. Outros testemunhos, como o de Luciano, em Histórias Verdadeiras (2, 33) e o de Pseudo-Calístenes, em História de Alexandre o Grande, ressaltam apenas a atividade de intérprete de sonhos. 
Com base, então, nos comentários díspares a respeito do autor e na separação inicial proposta por Hermógenes, há muito já se discutia a hipótese de que um orador ${ }^{21}$ chamado Antifonte, autor de discursos hipotéticos e de tribunal, e um autor homônimo tratado como sofista, deveriam ser separados. Aventou-se ainda a possibilidade de um terceiro: o adivinho e intérprete de sonhos. Desde o século XVI, com Aldo Manuzio (Veneza, 1513) e Henri Estienne (Paris, 1575), começaram a ser editadas as obras de Antifonte "orador", a quem a tradição, desde então, trataria de diferenciar do sofista. A repartição antiga, portanto, explicaria a repartição moderna das obras remanescentes em edições distintas. Desde a descoberta no século XX de vários fragmentos de papiro do Sobre a Verdade, ganhou força a posição que defendia a separação entre os supostos autores diferentes e as controvérsias envolvendo a identidade de Antifonte tornaram-se matéria de inúmeras discussões acadêmicas. Nesse texto, o seu autor aparentemente insinua uma visão igualitária da sociedade e defende a obediência às necessidades da

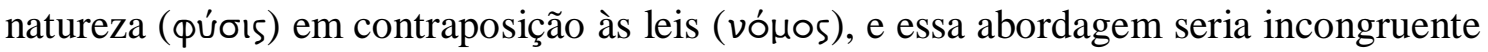
com a posição de um aristocrata identificado com um regime oligárquico.

Para alguns estudiosos modernos, como Louis Gernet e Gilbert RomeyerDherbey - seja com base em testemunhos antigos, seja pelas particularidades lexicais, conceituais e de elocução - seria evidente a separação. Romeyer-Dherbey, a partir da constatação do posicionamento político-ideológico de cada um, firma-se na hipótese separatista: "Um consensus parece bem fundamentado para os distinguir" (ROMEYERDHERBEY, 1986, p. 91). Para o estudioso, o orador, autor dos discursos para tribunal, “é um aristocrata, politicamente comprometido na oligarquia dos 'Quatrocentos', em que era um dos mais acérrimos adversários da democracia" (Ibid., p. 91). Quanto ao sofista, certamente com base nos fragmentos do Sobre a Verdade, tratar-se-ia de "um adepto da democracia, que denuncia os preconceitos nobiliárquicos e exalta o igualitarismo ao ponto de se opor à clivagem tradicional entre gregos e bárbaros” (Ibid., p. 91).

Já Gernet, na introdução de seu Antiphon (1954) ${ }^{22}$, não só nega que seja o mesmo homem o Antifonte orador e o Antifonte sofista, como também contesta a autenticidade das Tetralogias, por considerá-las, entre outras coisas, extremamente

\footnotetext{
${ }^{21}$ Como visto acima, no sentido primeiro de orador público ou de alguém que se dedica à prática do discurso

${ }^{22}$ ANTIPHON, 1954, p. 16
} 
sofísticas $^{23}$, visto que os aspectos presentes nestes discursos - a concepção, a ordem, os temas dos discursos - seriam comuns à "retórica dos sofistas"24.

Quanto aos estudiosos sensíveis à possibilidade de identidade entre os dois Antifonte, como Bárbara Cassin, J.S.Morrison, Fernanda Decleva-Caizzi e Michael Gagarin, parece ser evidente, baseando-se nos mesmos dados, a tese de um único autor. Bárbara Cassin em seu L'Effet Sophistique (1995), na introdução de sua tradução do texto Sobre a Verdade, apesar de assegurar que esta é uma questão em debate, defende haver um só Antifonte, mesmo que seja dupla a atividade ${ }^{25}$. Para ela, tanto o autor das Tetralogias, como o autor do tratado "sofístico" Sobre a Verdade e dos textos do Sobre a Concórdia, segundo suas palavras, não são outros que o "Antifonte real" ${ }^{26}$. Morrison, por sua vez, de acordo com essa hipótese unitarista, sustenta a fragilidade do argumento da elocução como forma de critério para o estabelecimento da distinção, visto que tal distinção, conforme visto acima, não existiria antes do gramático Dídimo, no momento em que justamente as obras coexistiam. Por isso mesmo, tal discriminação seria arbitrária. Além disso, para Morrison, seria natural a diferença na elocução de um escritor que teria lidado com discursos e tratados e isso em um período considerável de tempo. Em concordância com essa posição unitarista, Fernanda Decleva-Caizzi não só defende tal tese na introdução de seu Antiphontis Tetralogiae (1969), como também sustenta a possibilidade de relações entre as obras. Embora diga que é prudente manter certa incerteza sobre um fato não completamente claro, o autor das Tetralogias, o "orador" e o "sofista" são uma mesma pessoa ${ }^{27}$. Guthrie, por sua vez, em sua obra Os Sofista, é cuidadoso com relação ao assunto e ressalta uma informação, já apresentada acima, segundo a qual as referências a respeito de um "Antifonte Sofista" "não bastam para distinguir um sofista de um orador, uma vez que nos tempos antigos a palavra бoфıotńs se aplicaria igualmente a ambos" (GUTHRIE, 1995, p. 265). Por fim, quanto a Gagarin, cujo raciocínio é exposto em Antiphon, the speeches (1997) e em Antiphon, the Athenian. Oratory, Law, and Justice in the Age of the Sophists (2002), não haveria uma evidência muito forte para concluir que o "orador" e o "sofista" não são a mesma pessoa.

\footnotetext{
${ }^{23}$ ANTIPHON, 1954, p. 16

${ }^{24}$ Ibid., p. 16

${ }^{25}$ CASSIN, 1995, pp. 273-74

${ }^{26}$ Ibid., p. 116

${ }^{27}$ ANTIPHONTIS, 1969, p. 83
} 
Em se prosseguindo o exame dos lados contrários na polêmica sobre a questão da identidade de Antifonte, poderá ser confirmada ainda a falta de um consenso entre os estudiosos, pois diante da ausência de fortes evidências, não há provas conclusivas para o assunto. Parece bastante razoável, contudo, aceitar Antifonte como o autor tanto dos discursos para tribunal e para casos hipotéticos de homicídio como dos fragmentos do papiro que constituiriam os tratados sofísticos. Parece mais questionável, por certo, a atribuição ao autor da atividade de poeta como declarado por Pseudo-Plutarco. No mais, com relação às particularidades biográficas, as principais referências antigas - Tucídides, Xenofonte, Platão e Aristóteles -, parecem, de algum modo, se referir a um ateniense comprometido com a oligarquia dos "Quatrocentos" e reconhecido, sobretudo, pela reputação na habilidade em falar. As referências posteriores, com efeito, acabaram por acrescentar outras facetas a esse Antifonte, como a de adivinho e intérprete de sonhos, não sendo improvável que durante sua longa vida viesse a desempenhar não só estas como outras atividades.

Do ponto de vista das obras, é possível, como sugere Gagarin $^{28}$, que ainda na antiguidade elas de fato tenham sido inseridas em um mesmo corpus e tenham sido atribuídas simplesmente a um "Antifonte". Não parece, então, incongruente - como não parece ter sido entre os seus contemporâneos - que um autor, em um determinado momento, tivesse elaborado exercícios argumentativos sob a forma de discursos de tribunal e trabalhado neles tópicos importantes do período, como o faz nas Tetralogias; que tivesse composto discursos para serem efetivamente apresentados por outros em um tribunal, caso dos três discursos forenses; e que em algum momento de sua vida tivesse investigado, em um trabalho como o Sobre a Verdade, um assunto que teria sido importante na segunda metade do século $\mathrm{V}$ a.C. e que tradicionalmente passou a ser considerado de grande interesse dos "sofistas": a relação entre qúoıs e vónos.

As diferenças de elocução entre os trabalhos poderiam ser explicadas tendo em vista as épocas diferentes em que foram compostos, os diferentes propósitos de cada um deles e as diferentes audiências às quais foram dirigidos. As Tetralogias (c. 430 a.C.), talvez a composição mais antiga da prosa ática, possuem uma maior complexidade tanto no que diz respeito à elocução quanto aos argumentos nelas apresentados; tudo indica terem sido escritas não para a apresentação oral, mas com vista à leitura, à discussão e ao estudo por parte de uma audiência seleta - possivelmente uma audiência ateniense

\footnotetext{
${ }^{28}$ Cf. nota 20
} 
mais culta. Por outro lado, os discursos para tribunal, compostos entre 419 e 411, teriam sido elaborados em uma linguagem condizente com a apresentação oral em um tribunal ateniense, sem a complexidade sintática e as experimentações encontradas nas Tetralogias; foram compostos para outros apresentarem como seus e a audiência desses discursos era um júri de tribunal composto de cidadãos da pólis. Já em Sobre a Verdade (como também em Sobre a Concórdia e Político), composto em dialeto ático talvez no final do século $\mathrm{V}$ a.C., o interesse do autor possivelmente fosse o de oferecer a uma audiência específica - alunos ou outros pensadores - uma discussão acerca de um tópico importante no pensamento da época.

Por fim, quanto às diferenças conceituais, também utilizadas para discriminar os autores, não é possível afirmar que nas Tetralogias e no Sobre a Verdade Antifonte está declarando a sua própria opinião ou exibindo suas habilidades discursivas ao desenvolver exercícios argumentativos, no caso da primeira, ou propondo um problema que ele pretende investigar, no caso da segunda. Nas Tetralogias, Antifonte parece, sobretudo, interessado em colocar toda a ênfase na argumentação de assuntos específicos de seu interesse, a ponto de elaborar discursos para cada um dos três casos de homicídio, de modo a parecer o mais imparcial possível, ou seja, sem aparentemente favorecer um ou outro litigante, ou defender de maneira explícita um ou outro lado. Quanto aos discursos forenses, um logógrafo que escreve discursos para seus clientes não necessariamente expressa suas opiniões nesses discursos, como no caso de elogiar as leis em um discurso que será apresentado por alguém precisamente diante de um júri. E, finalmente, é difícil afirmar categoricamente que o autor em Sobre a Verdade faz uma defesa incondicional da фúoıs, até porque seu caráter fragmentário dificulta maiores conclusões - acredita-se que uma exposição sobre o vómos semelhante à apresentada sobre a qúois estaria na parte perdida do papiro; e, convém lembrar, como o próprio autor afirma em uma passagem do texto, que ele está lidando com problemas que ele se propõe investigar.

No mais, a importância dessa questão para o presente trabalho é notada se a abordagem acerca da identidade do autor for acompanhada do estudo dos textos, complementando-os. Isso é o que se pretende fazer adiante. 


\subsection{O ordenamento jurídico nos casos de homicídio na Atenas do século $\mathrm{V}$} a.C. ${ }^{29}$

Para entender as Tetralogias, em particular, pode ser útil, antes, destacar os elementos do ordenamento jurídico de Atenas na segunda metade do século V a.C. no que tange aos casos de homicídio. Para isso, as explicações de M. Gagarin (Speeches from Athenian Law, 2011), C. Carey (Trials from Classical Athens. 2001), A. Harrison (The Law of Athens, Procedure, 1971), A. Boegehold (The Lawcourts of Athens, 1997) e D. MacDowell (The Law in Classical Athens, 1991) parecem-nos bastante pertinentes. Em primeiro lugar, o sistema legal ateniense teria sido caracterizado por uma quase completa ausência de profissionalização ${ }^{30}$. Assim como em outras áreas do governo ateniense no século V a.C., não havia um cargo profissional, na medida em que todas as funções na democracia, com exceção dos estrategos (espécie de comandantes militares), eram escolhidas por sorteio por períodos não renováveis de um ano ${ }^{31}$. Assim, embora os cidadãos exercessem funções na administração da pólis em algum momento de sua vida, nenhum deles servia continuadamente para além do tempo estipulado para essa função. No mais, a participação no sistema legal - e político - restringia-se aos cidadãos atenienses, logo, aos indivíduos adultos (com mais de 30 anos) ${ }^{32}$ do sexo masculino. Essa restrição aplicava-se tanto à ocupação dos cargos públicos, quanto às votações da assembleia e para servir em um júri de um tribunal ${ }^{33}$. Além disso, em uma democracia direta como a ateniense era o próprio cidadão quem denunciava e se apresentava nos tribunais. Assim, no sistema legal ateniense, por exemplo, os casos eram apresentados para serem julgados não por cidadãos com alguma posição especial na cidade ou por “especialistas" (um perito em assuntos legais), mas por um quadro de cidadãos comuns

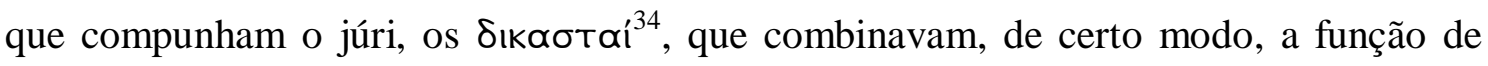
juízes e jurados nos sistemas legais modernos. Fato este que estaria entre as maiores

\footnotetext{
${ }^{29}$ No início de seu artigo Trials from Classical Athens (2001), Christoph Carey enfatiza que, de todos os Estados gregos, Atenas no período clássico (século $\mathrm{V}$ e IV a.C.), é aquele pelo qual temos mais informações sobre o sistema legal da Grécia antiga. Mas, segundo o autor, o problema é que, mesmo para Atenas, essas informações são escassas, o que, em última instância, dificulta uma descrição mais precisa do ordenamento jurídico ateniense (CAREY, 2001, p. 2).

${ }^{30}$ ANTIPHON, 1997, p. 9

${ }^{31}$ GAGARIN, 2011, pp. 5-6

${ }^{32}$ De acordo com Carey, antes de 451/0, um cidadão era um homem, adulto, filho de pai ateniense e mãe livre. Depois de 451/0, era aquele cujos pais fossem ambos atenienses (CAREY, 2001, p. 6)

${ }^{33}$ GAGARIN, 2011, p. 6

${ }^{34}$ CAREY, 2001, pp. 5-6
} 
contribuições para o estabelecimento da democracia em Atenas e para a administração da justiça, visto que um número limitado de cidadãos comuns representavam todos os cidadãos $^{35}$.

Nos tribunais, muitos julgamentos eram realizados diante de um júri de 201 a 501 cidadãos, chegando a atingir 1501 em casos importantes ${ }^{36}$. Os litigantes apresentavam cada um o seu caso em um discurso sem interrupção e com um limite de tempo específico. Um caso não poderia durar mais do que um dia e o tempo dos discursos era regulado por uma clepsidra (relógio d' água), a fim de assegurar igualdade para as partes. O primeiro discurso era destinado à acusação. A este, seguia-se o da defesa. Em seus discursos, os litigantes podiam apresentar as evidências através das declarações da testemunha, das leis, dos contratos, do testamento e de outros documentos. Em casos privados, a clepsidra parava para isso. Além disso, em contraste com um caso público, um segundo discurso era permitido para cada uma das partes em um caso privado. Encerrado os discursos, o júri decidia pela maioria dos votos. O litigante com maioria dos votos vencia a disputa. As penalidades eram geralmente multas monetárias. Os litigantes, porém, podiam propor outras formas de punição, como a pena de morte ${ }^{37}$.

Em Atenas, um procedimento legal era chamado de Síkn (ação judicial).

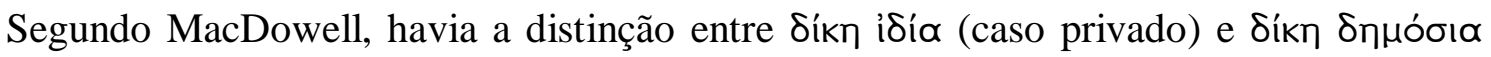
$(\text { caso público })^{38}$. Enquanto a primeira dizia respeito às ofensas contra particulares, a segunda dizia respeito aos casos em que uma ofensa ou uma disputa afetava a pólis como um todo. Naquela, apenas a vítima ou seus parentes podiam trazer uma acusação. $\mathrm{Na}$ outra, qualquer cidadão que quisesse tinha o direito de acusar.

MacDowell, em sua obra The Law in Classical Athens, ao tratar dos tipos de casos existentes na Atenas clássica, menciona que um tipo especial de caso privado era a $\delta ı \alpha \delta ı k \propto \sigma i ́ \alpha$, quando o caso envolvia um direito (p. ex., solicitar uma herança) ou uma obrigação (p. ex., ser um trierarca) ${ }^{39}$ e a disputa ocorria entre duas ou mais pessoas. Não havia acusador ou defensor, pois todos os requerentes estavam em condições iguais.

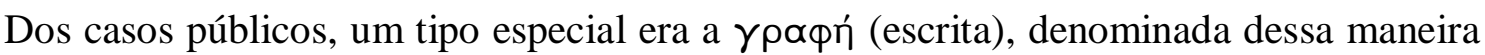

\footnotetext{
${ }^{35}$ MACDOWELL, 1991, p. 34

${ }^{36}$ GAGARIN, 2011, p. 9.

${ }^{37}$ Ibid., p. 10

${ }^{38}$ MACDOWELL, 1991, p.57

${ }^{39}$ Ibid., p. 58
} 
pois em sua origem era o único tipo de caso em que a acusação tinha que ser posta por escrito. A tradição atribui a Sólon o nome e o procedimento. Além da ypaqń, MacDowell elenca os diferentes nomes dados para casos públicos e seus aspectos distintivos. Todas essas variedades são apresentadas por MacDowell em um capítulo

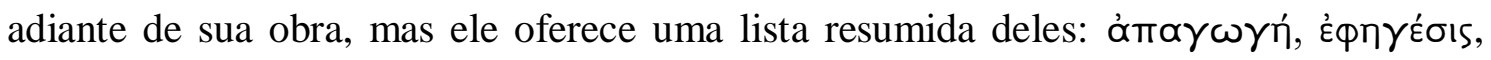

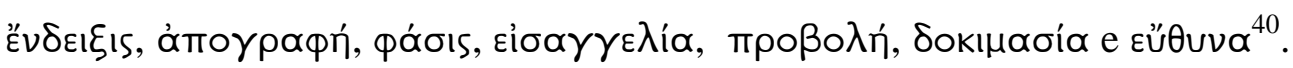

MacDowell afirma que um caso envolvendo homicídio (סíkn 申óvou) não se enquadraria em um caso privado em um sentido estrito ${ }^{41}$, visto que o assassino naturalmente não podia ser acusado pela vítima, que estava morta; mas também não se enquadraria em um caso público como a ypapŕ ou as outras variedades. MacDowell sugere que os atenienses do século V a.C. acreditavam que as leis para Síkn фóvou, conservadas praticamente sem alterações durante o período clássico, tinham sido instituídas por Drácon (ou eram ainda mais antigas). A Constituição Ateniense (7.1), por exemplo, nos informa que as primeiras leis escritas por Drácon, o primeiro legislador ateniense, em torno de 620 a.C., foram substituídas por Sólon em torno de 590 a.C., com exceção das leis de homicídio. Antifonte, no início de um de seus discursos para tribunal, o Sobre o Coreuta, ressalta a beleza e a sacralidade das leis de homicídio afirmando que são melhores que as demais por causa de sua antiguidade - "as mais antigas nesta terra" (6.2) - e de sua inalterabilidade - " são sempre as mesmas em relação aos casos idênticos, o que é o maior indício de que as leis foram bem-feitas, pois o tempo e a experiência ensinam aos homens sobre as que não o foram" $(6.2)^{42}$. Christoph Carey sugere que a antiguidade dessas leis elaboradas por Drácon e a relutância em alterá-las refletiria o conservadorismo ateniense em matéria de religião, visto que o homicídio contamina o assassino e todos aqueles que entram em contato com ele ${ }^{43}$. Harrison também acredita que, por razões religiosas, os antepassados dos atenienses do período clássico tinham sido extremamente conservadores com relação às leis de homicídio ${ }^{44}$.

A partir da inscrição sobre pedra em estado mutilado da lei de Drácon a respeito de homicídio, e de outras evidências, como os discursos de oradores e a Constituição

\footnotetext{
${ }^{40}$ MACDOWELL, 1991, p. 58

${ }^{41}$ Ibid., p. 59

${ }^{42}$ Tradução minha.

${ }^{43}$ CAREY, 2001, p. 26

${ }^{44}$ HARRISON, 1971, p. 35
} 
Ateniense, podem-se reconstruir alguns aspectos da lei, ainda que detalhes gerem controvérsias. Com efeito, na ausência de relatos narrativos circunstanciais, as reconstruções do sistema de tribunais de homicídio, no âmbito dos discursos, ficaram restritas aos três discursos de tribunal de Antifonte (1, 5 e 6) e aos três de Lísias, Sobre o assassinato de Eratóstenes (1), Contra Eratóstenes (12) e Contra Agoratos (13), e às três Tetralogias, também de Antifonte, que são, contudo, discursos para casos hipotéticos e que não foram elaborados para serem efetivamente apresentados e julgados em um tribunal.

O julgamento de homicídio, quanto ao procedimento legal, seria distinto de várias maneiras dos outros casos. Primeiramente, a acusação de homicídio devia ser feita por alguém próximo da vítima (parente ou amigo) por meio de uma petição privada contra o suposto assassino. O parente fazia, na ágora, uma proclamação pública nomeando o assassino e apresentando o caso ao Basileu ${ }^{45}$ (um dos nove arcontes ou chefes magistrados), que supervisionava os assuntos religiosos e se encarregava dos casos de homicídio. O Basileu fazia um anúncio formal instruindo o acusado a se afastar dos lugares públicos (como a ágora, onde estavam localizados os tribunais comuns) exceto o tribunal específico onde seria julgado - e dos lugares sagrados (como os templos) e, naturalmente, a se abster de várias atividades sociais e religiosas. $\mathrm{O}$ propósito dessa privação temporária de direitos civis talvez fosse o de evitar que o assassino, por ser impuro, contaminasse a cidade inteira ou, como sugere MacDowell, que essa exclusão da vida pública servisse para deter futuros assassinos ${ }^{46}$. $\mathrm{O}$ acusado, contudo, não era preso. O Basileu realizava, então, três audiências preliminares ( $\pi \rho \circ \delta ı к \alpha \sigma i ́ \alpha ı)$, cada uma em um mês distinto. Nelas era apresentado o esboço geral dos argumentos a serem apresentados no julgamento e as testemunhas eram ouvidas ${ }^{47}$. MacDowell sugere que nesses pré-julgamentos, sobre os quais de fato pouco se sabe exceto que discursos eram feitos pela acusação e pela defesa, o objetivo provavelmente era o de fornecer informações necessárias ao Basileu para que ele pudesse decidir o tribunal onde os casos seriam julgados ${ }^{48}$. A necessidade de três audiências preliminares

\footnotetext{
${ }^{45}$ Segundo Loomis, a função de Basileu, ou rei, era um resquício dos reis da Atenas pré-histórica. No tempo de Drácon, o Basileu era eleito anualmente por voto e suas obrigações principais eram religiosas. Suas obrigações legais, tal como lidar com casos de homicídio, derivaria de seus deveres religiosos, tendo-se em vista o caráter religioso do crime de sangue (a contaminação do estado). (LOOMIS,1972, p. 86)

${ }^{46}$ MACDOWELL, 1991, p. 111

${ }^{47}$ ANTIPHON, 1997, p. 12

${ }^{48}$ MACDOWELL, 1991, p. 118
} 
poderia ser explicada por causa da gravidade do crime envolvendo homicídio e, por isso, bastante tempo seria importante para acalmar as partes e fazê-las refletir se o julgamento de fato deveria seguir adiante ${ }^{49}$. O julgamento propriamente dito acontecia no quarto mês e era ouvido por um dos tribunais especiais de acordo com a acusação, a resposta da defesa e outras circunstâncias ${ }^{50}$. Com o mesmo propósito de evitar a contaminação pelo contato com quem estivesse poluído, os julgamentos eram realizados sempre ao ar livre.

Em número de cinco, os tribunais de homicídio eram separados e distintos um do outro. Esses tribunais funcionariam à parte dos tribunais populares (ou heliásticos). Alan Boegehold, em The Lawcourts of Athens - Sites, Buildings, Equipament, Procedure and Testimonia (1997), explica que o termo "tribunais de homicídio" não seria o modo mais preciso de se referir a esse sistema de procedimento judicial, pois, nesses tribunais, não eram ouvidos somente julgamentos resultantes de uma morte, mas também outros tipos de casos, como, por exemplo, acusações de incêndio premeditado, envenenamento, ferimento e conspiração ${ }^{51}$. Mas a nomenclatura "tribunal de homicídio", ressalta Boegehold, era utilizada pelos atenienses no século $\mathrm{V}$ e IV a. $\mathrm{C}^{52}$.

Os cinco tribunais de homicídio recebiam os nomes do lugar ou da estrutura em cuja área os Sıkaotaí permaneciam e julgavam ${ }^{53}$. O Areópago julgava casos de homicídio intencional $^{54}$, o Paládio, casos de homicídio não intencional, conspiração

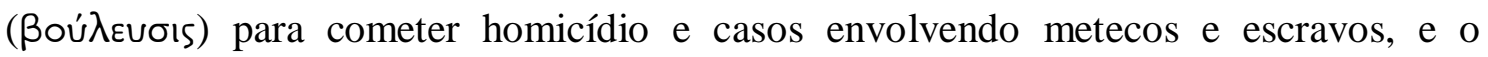
Delfínio, casos em que a lei exime o assassino de culpa por se admitir homicídios em legítima defesa. Exemplos de um caso para cada um desses três tribunais são fornecidos pela oratória: Antifonte, em Contra a Madrasta por envenenamento (1), apresenta um caso julgado no Areópago e, em Sobre o Coreuta (6), um caso julgado no Paládio; Lísias, em Sobre o Assassinato de Eratóstenes (1), apresenta um caso julgado no Delfínio. Além desses três tribunais, a Constituição Ateniense (57.3) indica outros dois tribunais de homicídio usados para casos especiais: o Pritaneu era reservado aos casos em que o assassinato era cometido por uma pessoa desconhecida, por um animal ou por

\footnotetext{
${ }^{49}$ MACDOWELL, 1991, p. 118

${ }^{50}$ GAGARIN, 2002, p. 136

${ }^{51}$ BOEGEHOLD, 1997, p. 43

${ }^{52}$ Ibid., p. 43

${ }^{53}$ Ibid., p. 43

${ }^{54}$ Após 462 a jurisdição do aristocrático Conselho do Areópago, o mais antigo dos tribunais, passou a se restringir a casos de homicídio e alguns casos religiosos (GAGARIN, 2011, p. 9).
} 
um objeto inanimado; e o Freato era reservado aos casos em que o assassino já estava no exílio; não podendo entrar na ática para participar do julgamento, permanecia em um

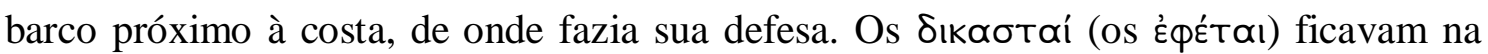
praia.

O júri de tribunais de homicídio era diferente do júri dos outros tribunais. $\mathrm{O}$ Areópago, por exemplo, o mais importante tribunal de homicídio, era composto por exarcontes, cidadãos com mais experiência legal e administrativa ${ }^{55}$. O Paládio e o Delfínio, assim como os outros dois tribunais de homicídio, eram comandados pelos 51 Éфétå, homens com mais de 50 anos escolhidos por sorteio, selecionados, talvez, dos membros do Areópago ${ }^{56}$.

De acordo com Gagarin ${ }^{57}$, um julgamento de homicídio (סíkn фóvou), por sua associação com a religião, diferia de outros casos quanto ao procedimento. Os litigantes faziam juramentos solenes e extensivos, a fim de que a verdade fosse falada. Incluía-se também um juramento de todas as testemunhas. Depois disso, cada lado discursava. Primeiro a acusação, seguido do discurso da defesa. Um segundo discurso de réplica, então, era pronunciado por cada uma das partes. Terminados os discursos, os juízes votavam imediatamente. Havia a possibilidade de o defensor optar pelo exílio antes do pronunciamento de seu segundo discurso. Nesse caso, o segundo discurso da defesa era apresentado por um parente ou amigo do acusado. A família da vítima, se concordasse, poderia autorizar a volta do assassino. Gagarin acredita que tais autorizações envolveriam frequentemente acordos financeiros ${ }^{58}$. Nos casos de homicídio intencional ou premeditado a punição era a morte e a propriedade do condenado era confiscada. Nos casos de homicídio não intencional, a pena era o exílio por um tempo limitado, talvez um ano. E para os casos em que a defesa alega homicídio em legítima defesa ou justificado, caso os juízes concordem, não há punição para o acusado; caso não concordem, o homicídio se converte em homicídio intencional e a pena será a morte. Se um homem, sentenciado ao exílio por homicídio, fosse encontrado em território ateniense, podia ser morto sem que o agente dessa ação fosse punido por isso.

Alguns dos tipos de homicídios justificáveis não sujeitos à punição diziam respeito à disputa atlética (p. ex., boxe ou luta livre), no caso de alguém matar

\footnotetext{
${ }^{55}$ CAREY, 2001, p. 27

${ }^{56}$ Ibid., p. 27

${ }^{57}$ GAGARIN, 2002, p. 135

${ }^{58}$ Ibid., p. 135
} 
acidentalmente seu adversário; ou à morte acidental de um soldado por seu companheiro em uma situação de guerra; ou à morte de um paciente enquanto estivesse sob cuidados médicos, estando o médico livre de culpa. Era ainda permitido matar em casos em que um homem fosse atacado por outro e se defendesse de seu agressor, desde que ficasse provado que o agressor, e não ele, atacou primeiro; ou quando um homem flagrasse sua esposa, mãe, irmã, filha ou concubina em um ato sexual com outro homem; ou quando um salteador realizasse uma emboscada em uma estrada ou tentasse roubar uma propriedade ou qualquer um que praticasse um roubo à noite. Nesses casos específicos, de acordo com as Leis (865 a), de Platão, a Constituição Ateniense (57.3), e uma passagem no discurso Contra Aristócrates (23.53) de Demóstenes, era permitido matar.

Sobre a necessidade de purificação, ela teria sido uma exigência para situações poluidoras como nos casos de crimes envolvendo derramamento de sangue. A explicação dada por MacDowell para os crimes de sangue é que, fossem eles intencionais ou não-intencionais, tivessem eles sido cometidos por alguma pessoa ou ocorridos por alguma circunstância externa, esse tipo de crime implicava na retirada de uma vida antes do tempo devido, e que, portanto, o morto deveria ser compensado com a punição de seu assassino ${ }^{59}$. A vingança, então, era uma exigência da família por ter sofrido injustamente ao ter um parente assassinado antes da hora. Uma vez que o assassino era visto como uma fonte de contaminação (miasma) capaz de se propagar e contaminar toda a cidade, a purificação, além da vingança, era a outra exigência desse tipo de crime ${ }^{60}$. O assassino ou aquele que era acusado de assassinato, enquanto não fosse julgado, deveria ficar impedido de entrar nos lugares públicos e religiosos, a fim de não contaminar outras pessoas. Pelo mesmo motivo, os julgamentos eram realizados em locais abertos. Por causa da seriedade desse crime, ficaria a cargo dos membros da família, e não de qualquer um $^{61}$, acusar o responsável. Por razões religiosas práticas, portanto, era necessário que ações legais fossem tomadas contra o culpado pelo homicídio.

A obra de Robert Parker (Miasma. Pollution and purification in Early Greek Religion, 1996) é um estudo mais adequado para a melhor compreensão da purificação e da contaminação na Grécia antiga. Em linhas gerais, o estudo explica que para algumas cidades gregas dos séculos VI e V a.C., dentre as quais Atenas, toda contaminação

\footnotetext{
${ }^{59}$ MACDOWELL, 1991, p. 110

${ }^{60}$ Vale lembrar que todo miasma era considerado contagioso e uma ameaça a pólis.

${ }^{61}$ MACDOWELL, 1991, p. 110
} 
(miasma) era considerada contagiosa e uma ameaça para a pólis, e havia a necessidade de rituais de purificação. Nascimento e morte eram considerados os dois eventos naturais poluidores frequentemente mencionados por fontes gregas ${ }^{62}$; por serem repugnantes aos deuses, deviam ser mantidos longe dos lugares sagrados ${ }^{63}$. Embora possa ter envolvido mais do que isso, Parker acentua que a exclusão dos templos das pessoas contaminadas é a única consequência atestada ${ }^{64}$. O nascimento e a morte deviam ser vistos pelos gregos como duas fontes de poluições similares, pois são constantemente mencionados juntos. No primeiro caso, tanto a gravidez quanto o parto eram considerados situações poluidoras e o lugar onde o nascimento ocorria ficava temporariamente contaminado. No segundo, o lugar da morte, o corpo do morto, seus parentes e as pessoas que tocavam no corpo também ficavam temporariamente contaminados. A contaminação referente à morte variava, quanto à intensidade, de acordo com a circunstância da morte. Se ela resultasse, por exemplo, de um assassinato ou de um suicídio, a contaminação era mais grave do que se tivesse ocorrido de outra forma. Parker explica que tanto o nascimento quanto a morte são momentos de transição para a sociedade em que alguns membros são incorporados e outros são perdidos ${ }^{65}$. Apesar de serem eventos naturais, representam igualmente violações da ordem: o morto ou a pessoa agonizante e a mulher grávida eram vistos como tendo perdido o controle de seus próprios corpos e o grupo social deveria se afastar enquanto mudanças cruciais não fossem operadas sobre eles. Os ritos de passagem poderiam ser vistos como o restabelecimento do controle e o medo da contaminação seria um produto do desejo de ordem e controle por parte de algumas cidades gregas.

Parker explica também que a crença grega nessas situações poluidoras teria uma aplicação especial: o papel de separar deuses e homens ${ }^{66}$. No mundo grego do século $\mathrm{V}$ a.C., o perigo real parece apenas ocorrer se os deuses são expostos a essas poluições naturais, ou seja, se estas poluições não são mantidas longe dos templos. Ao banir o nascimento e a morte dos lugares sagrados, os gregos, de acordo com Parker ${ }^{67}$, estariam enfatizando, sobretudo, a enorme distância que separa a natureza divina e a humana.

\footnotetext{
${ }^{62}$ As fontes apresentadas por Parker são algumas tragédias, como Antígona e Ájax de Sófocles, Hipólito, Suplicantes e Ifigênia em Tauros de Eurípides, a lei catártica de Cirene e a lei de Iulis de Quéos, estas últimas em estado fragmentário.

${ }^{63}$ PARKER, 1996, p. 33

${ }^{64}$ Ibid., p. 53

${ }^{65}$ Ibid., p. 63

${ }^{66}$ Ibid., p. 65

${ }^{67}$ Ibid., p. 66
} 
A ênfase na importância da poluição da morte seria um dos aspectos distintivos entre Homero e o século V a.C. Embora Parker enfatize que haja em Homero conexão entre morte e poluição enquanto uma mancha concreta, não haveria evidência do miasma afetando os vivos. Decleva-Caizzi também enfatiza que, em Homero, a impureza é de caráter material, físico, e pode ser extirpada com ablução ${ }^{68}$. Como também observa Gagarin ${ }^{69}$, os assassinos, por exemplo, não são retratados na épica homérica como contaminados, embora não seja possível afirmar que isso refletisse a crença comum dos gregos do século VIII. Já no período clássico seriam frequentes nas

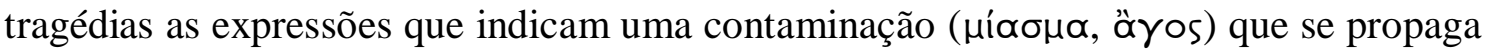
do assassino infectado para os lugares onde ele vive e sobre as pessoas com quem entra em contato. Nas tragédias, contudo, as situações geralmente apresentadas dizem respeito a um assassinato entre membros de uma mesma família e, portanto, envolvendo laços consanguíneos.

Curiosamente, o miasma teria papel relativamente menor em discursos de tribunal que lidam precisamente com casos de homicídio. Mesmo as leis de Drácon e Sólon, ao menos do que foi conservado, não mencionam nada sobre a impureza do assassino. Apesar de ressaltar a necessidade de um ritual de purificação em casos de assassinato justificável ou em legítima defesa, Gagarin ${ }^{70}$, por exemplo, não teria encontrado evidências de que o miasma fosse um aspecto significativo da lei de homicídio ateniense ${ }^{71}$. Não estaria presente, por exemplo, em um discurso como o Contra Agoratos (ca.399) de Lísias, acerca de um homicídio premeditado. No âmbito dos discursos que foram efetivamente apresentados em um tribunal e que chegaram até nós, apenas dois litigantes apelam diretamente ao assunto: em Sobre o assassinato de Herodes (5.82-84) de Antifonte, e em Contra Eratóstenes (12.99) de Lísias. Está ausente, contudo, do Contra a madrasta, por envenenamento [1], um discurso de acusação que lida justamente com um homicídio familiar, o tipo específico retratado nas tragédias. Essa ausência poderia indicar o papel relativamente menor do miasma na lei de homicídio ateniense no período clássico. Sealey, em The Tetralogies Adscribed to Antiphon (1984), também observa que, dos discursos que chegaram até nós que lidam com casos de homicídio (Antifonte 1, 5 e 6; Lísias 1, 12 e 13), referências ao miasma

\footnotetext{
${ }^{68}$ ANTIPHONTIS, 1969, pp. 25-6

${ }^{69}$ ANTIPHON, 1997, pp. 22-3

${ }^{70}$ Ibid., pp. 22-3

${ }^{71}$ Ibid., pp. 22-3
} 
não estão totalmente ausentes, mas são $\operatorname{raras}^{72}$. Assim como Gagarin, cita, como exemplo, a fala da acusação em Sobre o assassinato de Herodes (5.11) de Antifonte, que, primeiramente, lembra aos juízes que, para casos de homicídio, o julgamento deve ocorrer ao ar livre para que o assassino, que tem mãos impuras, não contamine os que estão no mesmo recinto. Mais à frente, em 5.82, diz que os homens que têm mãos impuras ou algum outro miasma arruínam consigo também os que viajam no mesmo barco. Sealey também cita a fala da acusação em Contra Eratóstenes (12.99) de Lísias, em que os "Trinta Tiranos" contaminaram templos ao adentrar neles. Essas, segundo o estudioso, seriam as únicas passagens de que se tem notícia em que há referências ao miasma em discursos de tribunal que foram efetivamente apresentados.

Em contrapartida, a crença do miasma decorrente do crime de sangue contaminando o assassino e que, enquanto não seja realizada a purificação devida, este deve ser excluído da sociedade, está presente de modo detalhado nas Tetralogias e nas Leis de Platão.

Nos textos de Antifonte, esse assunto parece ser um dos temas centrais, haja vista que está em quase todos os proêmios e epílogos dos três discursos. Neles, contudo, o miasma decorrente do crime de sangue é mostrado como atingindo o assassino aparentemente a visão tradicional -, mas também, possivelmente, os acusadores, se falham em sua acusação, e os juízes, se condenam um inocente ou absolvem o culpado. Além disso, reforça-se que a cidade inteira estará sujeita à contaminação caso o assassino não seja punido. Nas Tetralogias, de um modo geral, a acusação vai fundamentar seus argumentos na necessidade de vingança e de purificação da cidade, enquanto a defesa vai se concentrar na necessidade de se evitar uma nova contaminação resultante da execução de um inocente. Antifonte, contudo, não se interessa apenas pelo miasma decorrente do homicídio e pelos espíritos vingativos decorrentes desse crime que são encontrados nos discursos de tribunal acima mencionados -, mas também parece interessado em estabelecer um fundamento ou crença religiosa mais elaborada do miasma a ponto de, na opinião de alguns estudiosos ${ }^{73}$, divergir, sobretudo nesse sentido, da prática do direito ateniense, como atestariam os discursos existentes sobre casos de homicídios.

\footnotetext{
${ }^{72}$ SEALEY, 1984, p. 74

${ }^{73}$ Ibid., p. 74
} 
Nas Tetralogias, a crença de que o sangue da vítima impregna as mãos de seu assassino e que, enquanto não forem limpas, este deve ser excluído da pólis, a fim de não contaminá-la, não parece ser, contudo, a norma. É comum Antifonte, nas Tetralogias, substituir a mancha de sangue pela cólera da vítima ou o espírito vingativo

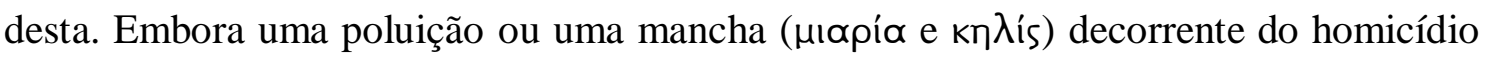
sejam mencionadas nas Tetralogias I e II, o recorrente nos três discursos é uma menção ao espírito vingativo do morto e à cólera dos espíritos infernais que agem em nome do morto: uma cólera que se propaga como miasma. Esse não só se configura em uma espécie de maldição - é a contaminação que o assassino espalha em torno de si, contaminando os lugares e as pessoas - mas também é identificado com a cólera da vítima, que exige vingança. Essa coexistência entre miasma e cólera do morto não seria estranha, pois, como observa Parker $^{74}$, essa correlação estaria implícita nos ritos de purificação, na medida em que à limpeza do sangue segue-se o apaziguamento da cólera.

Analisando, então, as Tetralogias, pode-se notar que o morto, para Antifonte, é троотро́тঞıs até que a vingança seja obtida. Ao menos nas Tetralogias, троотро́таıо significaria o espírito vingativo da vítima. Se os juízes falham, absolvendo o culpado, o espírito do morto que deseja vingança não se voltará contra o acusado, mas contra os que equivocadamente julgaram o caso. Como Decleva-Caizzi explica $^{75}$, a cólera do morto se personifica, assumindo figura autônoma, transformando-

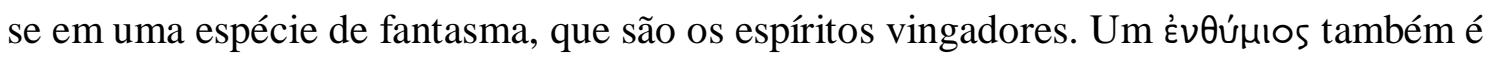
deixado aos juízes pelo morto. Em Heródoto (História, VIII, 54, 8) e em Tucídides

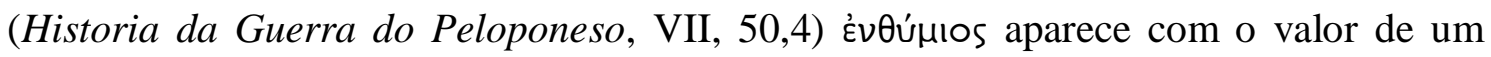
"peso" ou uma "preocupação" que atormenta aquele que não vingou uma vítima de crime de sangue. Esse sentido parece se adequar ao encontrado nas Tetralogias.

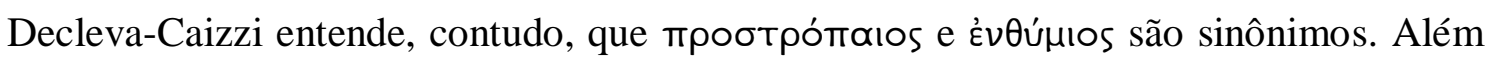
disso, outro termo importante é à $\lambda$ ıtńpıos, seres sobrenaturais, um equivalente à тробтро́тঞıьos, encontrado nas Tetralogias como os espíritos infernais que recaem sobre os assassinos de um inocente.

Essa identificação entre miasma e espíritos coléricos estaria confinada às Tetralogias e à tragédia. Evidências linguísticas presentes nesses textos e na oratória

\footnotetext{
${ }^{74}$ SEALEY, 1984, p. 107

${ }^{75}$ ANTIPHONTIS, 1969 , p. 28
} 
forense, na história e na comédia reforçariam, de acordo com Parker ${ }^{76}$, essa visão. Em linhas gerais, ele explica que um termo importante como тробтрóтঞı́s é usado de um modo nas Tetralogias $(2.3 .10,3.4 .9,4.1 .4,4.2 .8,4.4 .10)$ e de outro em Ésquilo (Agamêmnon, v. 1587; Coéforas, v. 287; Eumênides, vv. 41, 176, 234, 237, 445), com sentidos específicos em cada caso: o próprio morto em sua cólera ou seus espíritos vingativos, nas Tetralogias; o próprio assassino contaminado ou o sangue contaminado da vítima, nas tragédias. Outro termo importante como ádııńpıos, teria, tanto nas Tetralogias quanto nas tragédias, o sentido de seres sobrenaturais, ao contrário do encontrado em outros textos de outros gêneros, cujo sentido está relacionado a seres humanos contaminados. Parker sugere que essa atmosfera carregada de seres sobrenaturais nas Tetralogias e, sobretudo, em Ésquilo entre os tragediógrafos, talvez seja reflexo da antiguidade dessas composições ou, então, represente, ainda que de forma exagerada, a estrutura fundamental da crença popular do período ${ }^{77}$. O fato de uma crença semelhante a esta apresentada nas Tetralogias não ser referida pelos oradores subsequentes, ao menos de forma tão elaborada, não deve ser tomada, na opinião de Decleva-Caizzi ${ }^{78}$, como a prova de que esses discursos são a expressão de uma religiosidade supersticiosa isolada.

Outro texto que ilustra em detalhe o miasma decorrente de um homicídio é a obra As Leis de Platão. Nela, há uma passagem (866a-b - 871b-c) em que se afirma que o acusador que falha em acusar também traz para si o miasma, embora os juízes não sejam apresentados como estando sujeitos a uma possível punição, como sugerem as Tetralogias. No livro IX de As Leis, considerado o último trabalho de Platão, a personagem denominada Ateniense menciona que alguns tipos de homicídio implicam o assassino tornar-se um miasma, caso este se recuse a seguir a lei e frequente todos os lugares sagrados que frequentou o morto, aproximando-se dos altares e realizando sacrifícios com mãos impuras, além de se recusar a cumprir os períodos de exílio (866ab). O parente mais próximo, então, deve processar o assassino por homicídio. Caso não o faça, o miasma será transferido para ele "visto que a vítima desviará para ele suas reclamações pela fatalidade que se abateu sobre ela" (PLATÃO, 1999, p. 374). Dessa maneira, como nas Tetralogias, o miasma também recai sobre aquele que fracassa ao acusar o assassino de um parente. Outro caso semelhante é apresentado mais a frente em

\footnotetext{
${ }^{76}$ PARKER, 1996, p. 108

${ }^{77}$ Ibid., p. 108

${ }^{78}$ ANTIPHONTIS, 1969, p. 30
} 
871 b-c quando o Ateniense enfatiza que todo aquele que, deliberadamente, mas de modo injusto, matar com as próprias mãos qualquer integrante da cidade será impedido de comparecer nas assembleias legais e não deverá contaminar "com sua presença os templos, a ágora, os portos ou qualquer outro lugar de reunião" (PLATÃO, 1999, p. 380). Ele será advertido pela lei. No caso do parente mais próximo ser incapaz de processá-lo, recairá sobre este "a mácula e a ira dos deuses" (Ibid., p. 380).

Gagarin, contudo, não acredita que, em um julgamento em tribunal de Atenas, um litigante dedicaria tanto tempo sobre o assunto como ocorre com os oponentes em todas as três Tetralogias $^{79}$ e que provavelmente um argumento do miasma, segundo o estudioso, seria descabido em um discurso de tribunal. Na visão de Gagarin, deve-se entender o miasma nas Tetralogias não como um aspecto da lei ou da religião, mas como um material para a argumentação forense, visto que não interfere em outras considerações, no caso, nas argumentações nucleares do caso ${ }^{80}$. Opinião semelhante tem Andreas Bendlin. Em seu artigo Purity and Pollution $(2007)^{81}$, ele defende que a imagem do miasma do homicida contaminando a cidade até que o acusado seja julgado e condenado não deve ser interpretada como refletindo diretamente práticas e normas legais. Tal uso nesses discursos hipotéticos de Antifonte, que Bendlin considera exercícios de tribunal, serve como um meio retórico cujo objetivo é manipular - embora exageradamente - os sentimentos e emoções de um hipotético júri ateniense ${ }^{82}$.

Se, por um lado, as informações contidas nas Leis de Platão e na Constituição Ateniense, bem como nos discursos de tribunal de Antifonte e de Lísias para casos envolvendo crimes de sangue, nos ajudam, em alguma medida, a entender um pouco mais o sistema de tribunais de homicídio e a reconstruir alguns aspectos da lei de homicídio, por outro, com relação às Tetralogias, há uma dificuldade em se encontrar nelas informações pertinentes para um melhor entendimento do ordenamento jurídico para casos de homicídio na Atenas do século V a.C., pois uma análise dos textos sugere que não haveria, por parte de seu autor, uma preocupação em elaborar julgamentos em tribunais, mas exemplos de argumentos sob a forma de discursos forenses.

\footnotetext{
${ }^{79}$ ANTIPHON, 1997, p.8

${ }^{80}$ Ibid., p. 23

${ }^{81}$ Como a obra de Robert Parker, o artigo de Andreas Bendlin, contido em The Blackwell Companion to Greek Religion (2007), é outro estudo bastante útil para a compreensão da purificação e poluição na Grécia antiga.

${ }^{82}$ BENDLIN, 2007, p. 185
} 
Do ponto de vista da prática do direito ateniense, as Tetralogias - três grupos de quatro discursos envolvendo aquele que acusa e aquele que defende - possuiriam, ao menos à primeira vista, estruturas discursivas compatíveis com ela. Além da réplica da acusação e da defesa, Antifonte emprega um procedimento do direito ateniense no século V a.C., que é aquela possibilidade do exílio por parte do acusado antes de pronunciar o seu segundo discurso (4.4.1). Além disso, em todas as três Tetralogias, os litigantes são um parente ou amigo da vítima e o alegado assassino. Nos casos em que o litigante, no caso o réu, não pode fazer a própria defesa por ser ainda um jovem, como na Tetralogia II, ela é feita por um parente, em conformidade com a prática legal ateniense. Uma primeira divergência, contudo, diz respeito ao tempo dedicado ao primeiro discurso. Decleva-Caizzi ressalta que, em uma situação de tribunal, geralmente os primeiros discursos eram mais longos do que os pronunciados pela réplica ${ }^{83}$. Nas Tetralogias, Antifonte respeita, na maior parte do tempo, um equilíbrio entre os discursos dos litigantes. E quando isso não ocorre, como na Tetralogia II, o desequilíbrio favorece a defesa. Ao contrário de um tribunal ateniense, nas Tetralogias os testemunhos estão relativamente ausentes e as narrativas são omitidas ou reduzidas ao essencial, permitindo ao autor se concentrar nos argumentos. O proêmio e o epílogo são cuidadosamente modelados e neles é trabalhada uma versão mais elaborada da crença religiosa do miasma. Mesmo a formulação de uma lei proibindo homicídio justo e injusto apresentada por Antifonte, na Tetralogia II e III, aparece como uma regra do código legal ateniense.

Dada, então, a própria natureza das Tetralogias - exercícios argumentativos e não discursos de tribunal -, haveria uma dificuldade de adequá-las ao direito ateniense, principalmente no que diz respeito a qual tribunal pertence cada um dos casos contidos em cada um dos discursos hipotéticos de Antifonte. Como sustenta Decleva-Caizzi ${ }^{84}$, eles não correspondem sequer à tríplice divisão tradicional do direito ático em casos de థóvos Ékoúolos (homicídio intencional), фóvos åkoúolos (homicídio não-intencional) e

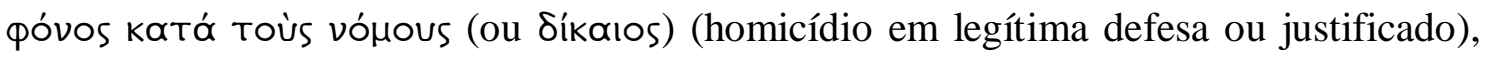
de competência, respectivamente, do Areópago, do Paládio e do Delfínio. Se a Tetralogia II, de certo modo, poderia se adequar ao esquema tradicional, o mesmo não ocorreria com as demais. No mais, o próprio título e subtítulo que antecipam os

\footnotetext{
${ }^{83}$ ANTIPHONTIS, 1969, pp.11-2

${ }^{84}$ Ibid., p. 12
} 


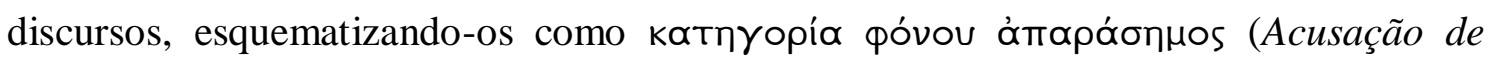

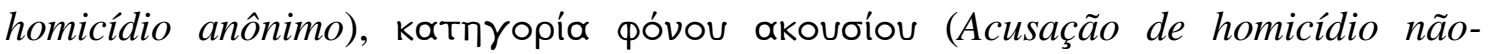

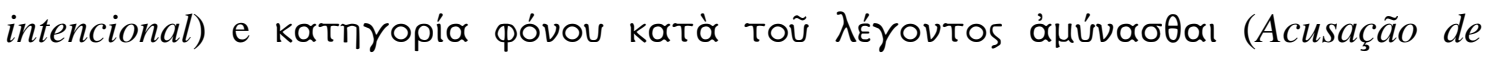
Homicídio contra alguém que diz se defender), são obras de um gramático posterior e

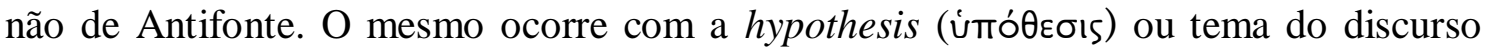
(uma introdução aos casos), escrita por algum estudioso antigo, mas não por Antifonte. De acordo com essa hypothesis, o "estado de causa" ou a "tese em disputa" da

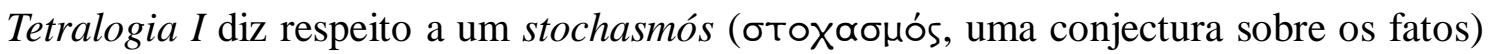

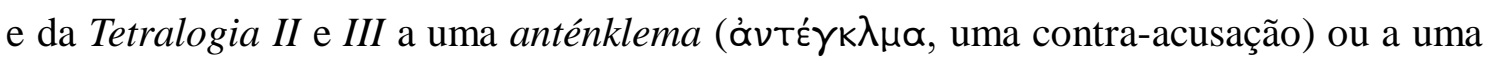

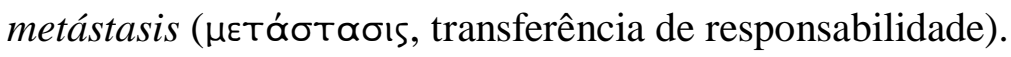

Embora a divisão sistemática das staseis ou "teses em disputa" (otóoøı; lat. status) seja um produto da análise retórica do século II a.C., o autor das Tetralogias parece sugerir à sua audiência uma divisão básica das teses como "questões de fato" e “questões de lei” ou "de definição legal”, divisão essa que seria justamente a base da teoria da stasis e que desempenhou um importante papel na teoria retórica helenística e romana ${ }^{85}$. Antifonte, na Tetralogia II, por exemplo, elabora um caso em que os fatos

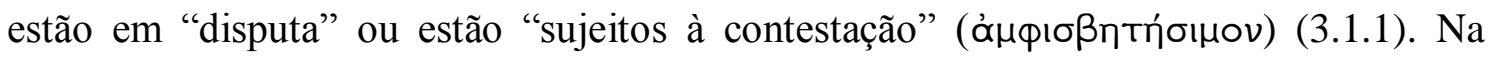
opinião de Gagarin ${ }^{86}$, tanto Antifonte quanto Górgias teriam compreendido a distinção básica apresentada posteriormente na Retórica (I.13.9-10, 1373b38-74a17) de Aristóteles entre os casos em que os fatos estão em disputa e os casos em que os fatos são admitidos, mas a defesa nega haver um crime. Na Defesa de Palamedes, Górgias compõe um discurso para um caso em que algo teria ocorrido ou não: Palamedes

\footnotetext{
${ }^{85}$ Embora haja evidência de uma teoria da stasis na Retórica de Aristóteles, o desenvolvimento de um procedimento formal seria encontrado nos escritos de Hermágoras (século II a.C.), cujo tratamento da stasis teria refletido em muitos autores posteriores de retórica gregos e latinos. Apesar de nada ter sobrevivido desses escritos, sua teoria retórica pôde ser reconstruída graças a autores como Cícero, Quintiliano e Hermógenes.

Utilizando a definição de Michael Carter (Stasis and kairos: Principles of social construction in Classical Rhetoric, 1988), a stasis era um método pelo qual se identificava a área em desacordo, o ponto a ser argumentado, o assunto sobre o qual um caso se articulava (CARTER, 1988, p. 98). Quanto à formulação das classes e subclasses da teoria de Hermágoras, a explicação de Kennedy é bastante clara. De acordo com ele, as "questões políticas", isto é, as questões que envolviam os cidadãos, eram divididas em duas classes: thésis (uma controvérsia que não envolvia indivíduos específicos ou definidos) e hypóthesis (uma controvérsia específica envolvendo indivíduos nomeados e ocasiões definidas). A hypóthesis, por sua vez, era subdividida em questões de fato ou de justiça (quaestiones rationales) e questões de lei (quaestiones legales). Era em sua análise acerca da hypóthesis que Hermágoras estabelecia as linhas básicas da teoria da stasis, (as teses em disputa ou os estados de causa de diferentes casos). Quatro eram as staseis usadas por ele: stochasmós (a conjectura dos fatos), hóros (a definição), katà symbebekós ou poiótes (contingência ou qualidade) e metálepsis (objeção). Cada uma das quatro staseis, por sua vez, era dividida em outras subclasses.

${ }^{86}$ ANTIPHON, 1997, p. 122.
} 
cometeu, ou não, uma traição contra os gregos em favor dos troianos? Na Tetralogia I, Antifonte apresenta um caso em que os fatos estão em disputa e a questão colocada é se o réu realizou a ação de que é acusado. Por outro lado, no Elogio de Helena, Górgias compõe um discurso em que os fatos são aceitos, mas sua interpretação está em disputa. Na Tetralogia II, o caso é modelado de modo que também haja concordância de ambos

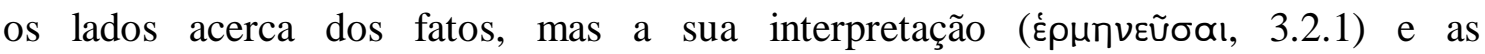
consequências legais estão em disputa: a questão é se o réu seria responsável legal pela morte de um garoto. Na Tetralogia III, apesar de vários assuntos serem levantados, dentre os quais a interpretação, em alguma medida, dos fatos, o principal assunto é o da justificação de uma ação: a alegação do acusado de ter agido em legítima defesa.

Do ponto de vista do sistema legal ateniense do século V a.C., as Tetralogias, portanto, parecem acrescentar poucas informações importantes para um melhor entendimento dele. Um consenso em torno desses discursos de Antifonte é o de serem exercícios escolares ou argumentativos que, reproduzindo, em alguma medida, a prática do direito ateniense do período, ilustram diferentes tipos de argumentos em possíveis casos de homicídio. Os casos legais neles trabalhados se aproximariam de algum modo da "tese em disputa" (stasis). Nesses exercícios, Antifonte não precisaria se preocupar com os detalhes de uma lei, embora o contexto legal fosse geralmente consistente com a lei ateniense. Ao não se preocupar em elaborar casos de homicídios possíveis para tribunal, Antifonte poderia colocar toda a ênfase na argumentação de assuntos específicos de seu interesse, muitos dos quais tópicos importantes do pensamento e da argumentação do século V a.C. Questiona-se, contudo, se foram compostos com o intuito de exibir as habilidades argumentativas e intelectuais do autor para uma audiência pública ou privada e/ou de instruir jovens na prática da argumentação, não apenas forense.

\subsection{As antilogias e as Tetralogias}

Outro aspecto importante para o estudo das Tetralogias é observar que são

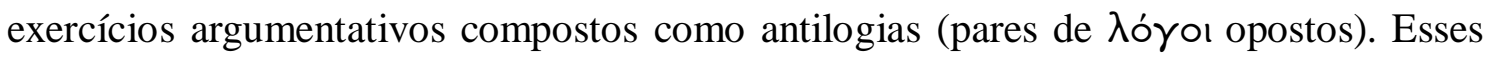
$\lambda$ $\lambda$ yoı (no caso, “discursos") são pronunciados como se apresentados por litigantes em um tribunal, utilizando-se, em alguma medida, da legislação de homicídio e do 
procedimento legal atenienses, a exemplo da apresentação em tribunal estruturada em dois discursos iniciais de acusação e defesa e suas respectivas réplicas, configurando-se tetralogias.

Em cada uma das Tetralogias parece claro que o autor busca demonstrar como um mesmo assunto pode ser explorado exaustivamente pelos discursos dos supostos adversários em uma determinada contenda. Essa composição mediante $\lambda o ́ \gamma o$ (em seu sentido mais amplo de "discursos", "argumentos", "raciocínios") contrários sobre um mesmo assunto teria sido uma prática comum de argumentação sobretudo no século $\mathrm{V}$ a.C. e seria reflexo de uma pólis, como a ateniense, em que a apresentação pública e os debates frequentemente se realizavam sob a forma de disputa. Embora procedimentos como a performance oral já estivessem presentes na poesia pelo menos desde o período homérico ${ }^{87}$, a Atenas do século V a.C., por suas condições políticas, teria fortalecido, em grande medida, práticas ou atividades relativas ao discursar (inclusive pela atuação nela de estrangeiros que a ela chegavam como embaixadores, casos de Protágoras e Górgias). Pois a vida pública em uma democracia como a ateniense exigia falar e debater em tribunais e, sobretudo, na assembleia. Ou seja, era permitido a todos os cidadãos falar na assembleia e no tribunal. No período de Péricles, Atenas havia se tornado um centro da Hélade. Nesse contexto, surgem novas maneiras de pensar, em grande medida associadas a pensadores que foram denominados, especialmente e posteriormente por Platão, de "Sofistas". A prática do discursar adquiriu novos contornos, como é o caso da exploração de novos procedimentos de argumentação com um propósito diverso do meramente discursar em uma assembleia ou em um tribunal, voltado menos para um uso prático no sentido de um treinamento para falar em público.

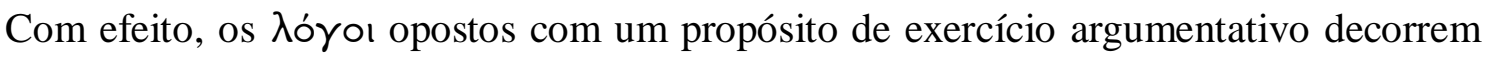
dessa nova modalidade discursiva.

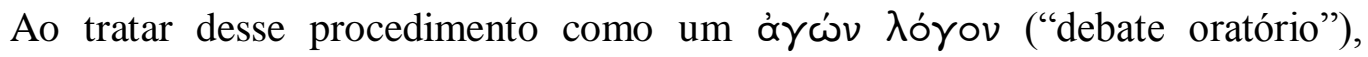
Romilly ressalta que esse era uma tendência generalizada no século V a.C., e "que ocorria quase por toda parte" (ROMILLY, 1998, p. 117). A disputa jurídica e política seria a forma mais simples desse procedimento, mas "todos os gêneros literários o praticam" (Ibid., p. 117), conforme alega a autora. De fato, a tradição política e os debates de tribunal operavam como uma disputa entre dois lados opostos envolvendo normalmente um par de discursos (algumas vezes dois pares, no caso dos tribunais de

${ }^{87}$ WORTHINGTON, 2007, p. 255 
homicídio). Mas é possível observar que, já nos séculos VI e V a.C., alguns pensadores lidavam com vários tipos de pares opostos, em uma mostra de que já havia a prática na cultura grega como um todo do pensamento estruturado em termos de contrários ${ }^{88}$. É importante ressaltar também que mesmo o ơyćv trágico e cômico muitas vezes opunha argumentos contrários, e cenas de debate eram bastante comuns não somente na tragédia e na comédia, mas também na poesia épica. Gagarin, por exemplo, acredita que, a partir da segunda metade do século V a.C., a prática de compor pares de discursos, deixando de se limitar ao âmbito legal ou semilegal, começou a ser usada também para uma prática argumentativa ${ }^{89}$. Essa mudança é geralmente atribuída a Protágoras.

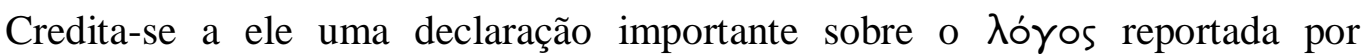
Diógenes Laércio referindo-se a um fragmento que destaca ser ele "o primeiro a dizer

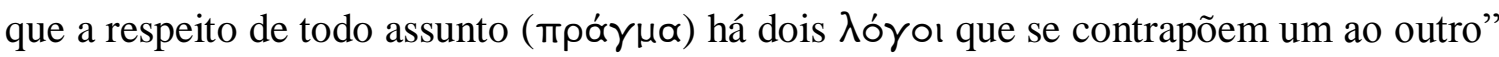

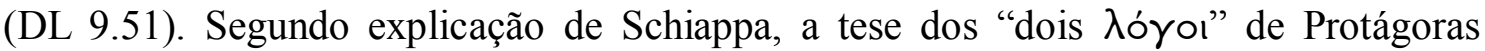
seria uma extensão da teorização contemporânea sobre a natureza das "coisas" entendendo a natureza a partir dos "opostos" possível tratado de Protágoras supostamente denominado Antilogiae, cujo tema principal seria precisamente o dos $\lambda$ óyoı opostos, acredita-se ${ }^{91}$ que se tratava de um conjunto de pares de argumentos opostos sobre vários assuntos. Gagarin sugere que daí resultaram algumas composições de pares de discursos apresentando diferentes lados de um mesmo assunto com fins mais teóricos, uma forma de composição que se denominou exatamente de Antilogiae ${ }^{92}$.

As Tetralogias de Antifonte e os Dissoi Logoi (ou Duplos Discursos), um texto anônimo incompleto (ca. 400 a.C.), seriam exemplos completos de $\lambda$ óyoı opostos do século V a.C. Nas Tetralogias, acusação e defesa, no âmbito do discurso de tribunal, discursam por duas vezes cada uma e de maneira intercalada, implicando em sua estrutura algo como um julgamento ateniense. A importância dessa obra de Antifonte se justifica pois trata-se do único caso conhecido em que há dois pares de discursos que se contrapõem. Nos Dissoi Logoi, um autor apresenta argumentos a favor e contra várias

\footnotetext{
${ }^{88}$ No estudo de Kirk, Raven e Schofield sobre os filósofos pré-socráticos, cogita-se que é em Anaximandro que "se encontra, pela primeira vez, o conceito de substâncias naturais contrárias (conceito que reaparece em Heráclito, Parmênides, Empédocles, Anaxágoras e, certamente, nos pitagóricos desde Alcméon)" (KIRK, RAVEN, SCHOFIELD, 1994, p. 119)

${ }^{89}$ GAGARIN, 2002, p. 24

${ }^{90}$ SCHIAPPA, 1999, p. 79.

${ }^{91}$ GAGARIN, 2002, p. 22

${ }^{92}$ GAGARIN, 2001, p. 282
} 
proposições (bom e mau; justo e injusto; belo e feio; verdadeiro e falso). Além desses dois textos, haveria uma passagem nas Memoráveis (2.1.21-34) em que Xenofonte apresenta uma versão do trabalho de Pródico em que duas mulheres, Virtude e Vício, a fim de atrair Héracles para o seu modo de vida, fornecem discursos opostos. O debate entre Cleon e Diódoto (a antilogia dos Mitilenos) na História da Guerra do Peloponeso de Tucídides também seria composto em pares. No estudo História e Razão em Tucídides (1998), Romilly ressalta outras séries de antilogias espalhadas pela obra de Tucídides: o debate entre Cleon e Diódoto no livro III; o debate entre os plateenses e os tebanos (III, 53-67); os corcireus e os corintios (I, 32-43); e os discursos entre Hermócrates e Eufemos (VI, 76-87); Hermócrates e Atenágoras (VI, 33-40); e Nícias e Alcibíades (VI, 9-18). Todos são pares de discursos reforçando também o apreço de Tucídides por esse procedimento.

Em seu artigo Did the sophists aim to persuade? (2001), Gagarin insere outros trabalhos dos séculos V e IV a.C. na categoria daquilo que ele considera " $\lambda$ ó $\gamma$ o sofísticos" compostos na forma de antilogia. Ao lado das Tetralogias e dos Dissoi Logoi, ele acrescenta o único par de discursos de Antístenes, Ájax e Odisseu ${ }^{93}$. Provavelmente escritos do começo do século IV a.C., neles o autor explora uma questão trazida da tradição mítica a fim de inserir a modalidade de discurso própria de seu tempo. De fato, Antístenes apresenta diferentes lados de um mesmo assunto: a célebre disputa sobre as armas de Aquiles.

Juntamente com as Tetralogias e os Dissoi Logoi, também o par de discursos de Antístenes aplicaria explicitamente os $\lambda o ́ \gamma o$ opostos. Além desses textos, essa prática argumentativa, segundo o próprio Gagarin, poderia ser encontrado implicitamente em outros importantes discursos contemporâneos às Tetralogias. Em Defesa de Palamedes e Elogio de Helena de Górgias, por exemplo, é possível encontrar o caráter agonístico

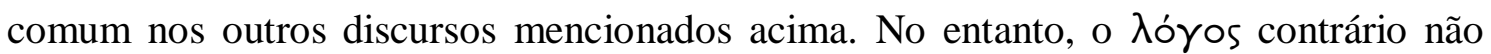
ocorre, ou, ao menos, ocorre apenas de maneira implícita, tendo-se em vista a tradição poética e mítica aos quais se referem. Gagarin justifica a inserção dos dois discursos de

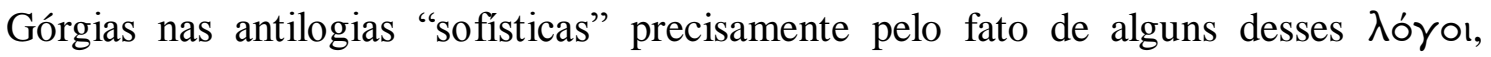
mesmo não sendo compostos em pares, serem modelos de composição agonística como parte implícita de uma antilogia ${ }^{94}$. No Elogio de Helena, Górgias contesta a culpa de

\footnotetext{
${ }^{93}$ GAGARIN, 2001, p. 282

${ }^{94}$ Ibid., p 283
} 
Helena - a versão tradicional do mito - partindo da narrativa tradicional dos poetas sobre o rapto de Helena. Em Defesa de Palamedes, a apologia deste pressupõe a acusação de Odisseu contra Palamedes conhecida graças à certa tradição poética. Nos

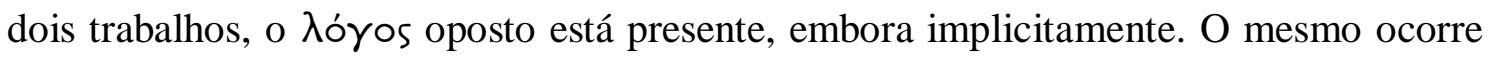
com o Odisseu de Alcidamante, um discurso do século IV a.C., que trabalha uma versão do discurso de Odisseu contra Palamedes. Essa versão provavelmente foi uma resposta à versão de Górgias na Defesa de Palamedes, com o qual ele seria comparado, na medida em que Alcidamante apresenta justamente uma acusação para o julgamento de Palamedes.

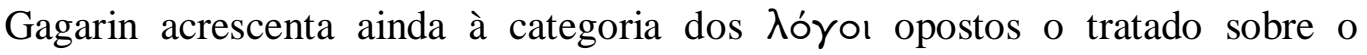
governo de Atenas tecnicamente chamado de Constituição de Atenas, atribuído a Xenofonte, mas que provavelmente seria de um autor anônimo comumente denominado de $O$ Velho Oligarca. O tratado pertenceria ao debate do século V a.C. acerca dos méritos relativos às diferentes constituições e talvez tenha sido um exercício que, à maneira dos Dissoi Logoi, necessitou da avaliação dos prós e dos contras ${ }^{95}$. Os dois relatos tradicionalmente atribuídos aos supostos inventores da retórica, Tísias e Córax, também são inseridos nessa categoria. Um é o exemplo encontrado na Retórica (II, 1402 a18-21) de Aristóteles da luta entre um homem fraco e um homem forte. O homem fraco argumenta que não seria plausível que ele, em razão de sua fraqueza, agredisse um homem forte. $\mathrm{O}$ homem forte contesta esse argumento com outro contrário, segundo o qual não seria plausível que ele, um homem forte, agredisse um homem fraco, pois a suspeita do crime imediatamente recairia sobre ele; por ser plausível que ele

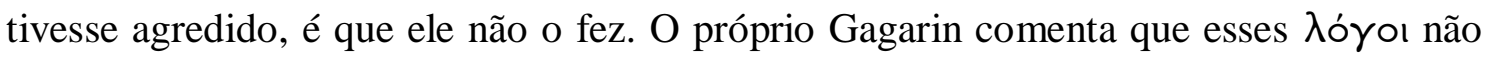
são considerados um par de argumentos opostos ${ }^{96}$. Entretanto, trata-se de dois argumentos opostos entre si e que lidam com um assunto em comum. O outro relato é a história, provavelmente apócrifa ${ }^{97}$, segundo a qual Tísias, discípulo de Córax, se recusou a pagar por sua instrução após receber as aulas de Córax. O caso teria sido levado ao tribunal onde Tísias teria argumentado que se vencesse o caso, de acordo com o veredito ele não pagaria pela instrução, mas se perdesse seria a prova clara de que os ensinamentos de Córax não teriam valor, logo, não deveriam ser pagos. Córax, então, teria argumentado exatamente com um $\lambda$ óyos oposto: se ele vencesse o caso, de acordo

\footnotetext{
${ }^{95}$ GAGARIN, WOODRUFF, 1995, p. 133.

${ }^{96}$ GAGARIN, 2001, p. 283

${ }^{97}$ SCHIAPPA, 1999, p. 5
} 
com o veredito, receberia por sua instrução, mas, se perdesse, ficaria claramente provado que seus ensinamentos têm valor. Logo, Tísias deveria pagar por eles. De acordo com Gagarin ${ }^{98}$, trata-se de uma antilogia em que os dois $\lambda$ óyoı são exatamente sobre o mesmo assunto, mas opostos entre si. Se o segundo relato é possivelmente uma anedota, o primeiro talvez tenha feito parte de uma coleção de modelos de discursos que lidam com posições favoráveis e contrárias ( $\lambda$ óyo contrários) sobre um determinado assunto, talvez para uso em processos judiciais.

Com efeito, todos esses discursos e argumentos mencionados acima parecem ilustrar bem a prática argumentativa das antilogias utilizada no século V a.C. Nesses textos não parece haver, à primeira vista, o objetivo de persuadir uma audiência de uma

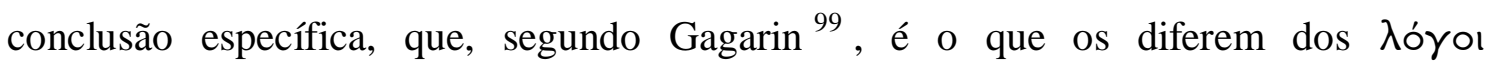
apresentados nos tribunais ou na assembleia. Parecem, antes, serem explorados com fins pedagógicos para uma prática argumentativa, possivelmente exercícios voltados a uma audiência específica, talvez uma audiência seleta e culta ${ }^{100}$. Isso faz sentido se se observar que, no geral, o lado vitorioso do debate não é indicado, nem que um dos dois argumentos apresentados é melhor ou pior do que o outro. Nas Tetralogias, por exemplo, o veredito final não é dado. Nos Dissoi Logoi, os argumentos opostos são apenas justapostos e não são comentados ${ }^{101}$. Mesmo no Elogio de Helena, Górgias aparentemente tem por objetivo menos persuadir uma audiência da inocência de Helena do que apresentar suas habilidades do ponto de vista da elocução e argumentação. Igualmente para o par de discursos de Antístenes e o discurso de Alcidamante. Um dado interessante é que, primeiro, essas antilogias são compostas para situações hipotéticas em que o autor não reivindica alguma decisão ou veredito em favor de um dos dois

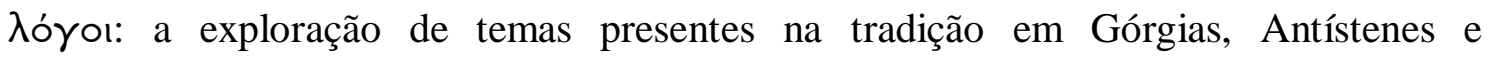
Alcidamante; o cenário forense hipotético em Antifonte; a argumentação nos Dissoi

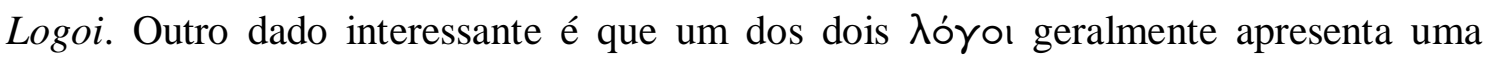
visão tradicional de um assunto, enquanto o outro explora um raciocínio novo e sofisticado, como por exemplo, os argumentos contrários das proposições apresentadas nos Dissoi Logoi; os discursos de defesa das Tetralogias; os discursos de Górgias. No

\footnotetext{
${ }^{98}$ GAGARIN, 2001, p. 283

${ }^{99}$ Ibid., p. 284

${ }^{100}$ Gagarin, por exemplo, acredita que o público das Tetralogias era composto por uma audiência letrada, possivelmente intelectuais de Atenas e de outras cidades, não apenas jovens em busca de uma educação (GAGARIN, 2002, pp. 105 e 133).

${ }^{101}$ GAGARIN, 2002, p. 31
} 
mais, nesses pares de $\lambda$ ó $\gamma o$, a ênfase parece recair sobre os argumentos neles trabalhados. E antes de pretenderem persuadir uma audiência, visto que são exercícios argumentativos, seriam compostos, como sugere Gagarin ${ }^{102}$, talvez com o intuito de entreter, ensinar, provocar ou deslumbrar essa própria audiência.

\subsection{Sobre a elocução nas Tetralogias.}

Se se pode confiar na data de composição das Tetralogias e se podem ser atribuídas a Antifonte, esses discursos teriam sido elaborados durante o estágio de formação da prosa ática, por um autor apresentado pela tradição como o primeiro dos oradores áticos e considerado, pelos textos e comentários que chegaram até nós, o primeiro ateniense a escrever textos nesta nova modalidade do discurso.

Duas informações são importantes para um melhor entendimento das Tetralogias. $\mathrm{Na}$ metade do século $\mathrm{V}$ a.C., o jônio era o dialeto comum a pensadores, seja em prosa, seja em verso, como Anaximandro e Anaxímenes; Xenófanes e Parmênides; Heráclito, Demócrito e Anaxágoras. A prosa jônica também era representada por Heródoto; pelos escritos médicos contidos no corpus hipocrático; por trabalhos atualmente perdidos de alguns sofistas, como Protágoras. Falar, então, de prosa grega significava falar de prosa jônica. Além dela, o drama ático, representado principalmente pelas peças trágicas de Ésquilo e de Sófocles, era, sobretudo nas falas das personagens contidas nos episódios, outro importante modelo de uso na época. E acredita-se que tanto esse ático do drama e o jônio da prosa devem ter influenciado, de algum modo, as Tetralogias.

Esses dois aspectos, mais o fato de Antifonte escrever em um período em que a prosa ática está sendo modelada, poderiam justificar, talvez, a utilização de novos efeitos de elocução nas Tetralogias e explicar as variações relativas ao dialeto, à morfologia e à sintaxe encontradas nesses discursos específicos.

A fim de melhor compreender as Tetralogias, é pertinente apresentar alguns dos principais elementos que constituem a elocução da prosa de Antifonte nesta obra, e que o tornaram notório, assim como Tucídides, pela densidade e concisão. Em primeiro lugar, procuramos apresentar alguns dos vocábulos jônicos utilizados pelo autor ao longo de seus três discursos. Em um segundo momento, apresentamos palavras e

${ }^{102}$ GAGARIN, 2002, p. 31 
construções comuns à poesia empregadas por Antifonte, bem como o seu apreço pela formação de novos vocábulos. Em um terceiro momento, lidamos com a estrutura das frases, caracterizadas pela antítese e paralelismos. Por último, tratamos de dois elementos utilizados em grande quantidade pelo autor: a perífrase e o particípio.

\section{Dialeto jônico:}

A influência do dialeto jônico pode ser percebida pela quantidade de expressões e palavras jônicas presente nas Tetralogias. Em geral, são palavras jurídicas, cujos significados são raros em Ático na época de Antifonte. A saber:

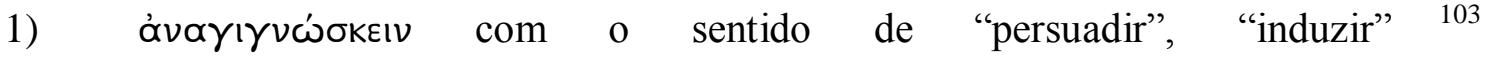

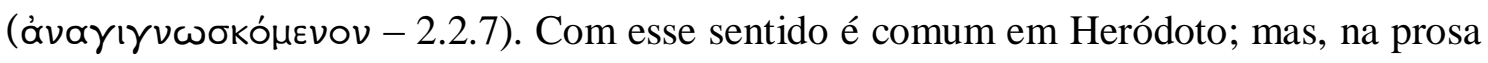
ática, somente nas Tetralogias.

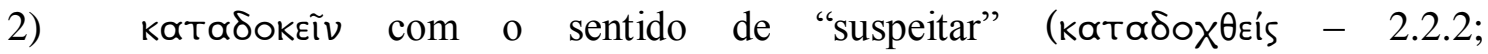

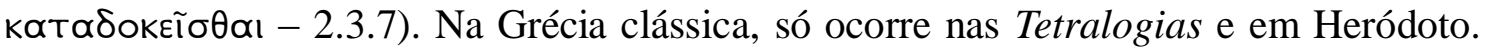

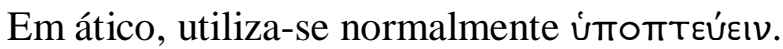

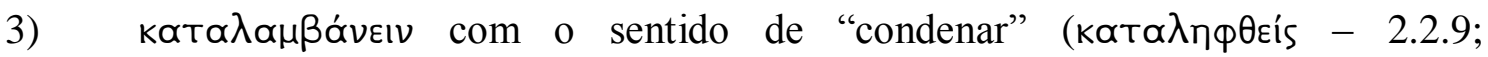

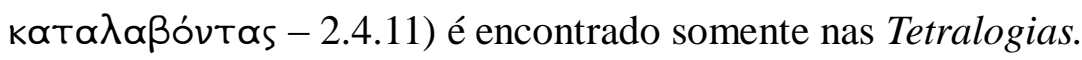

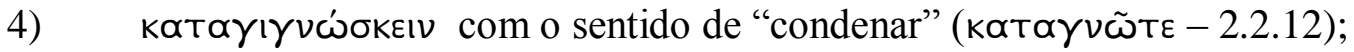

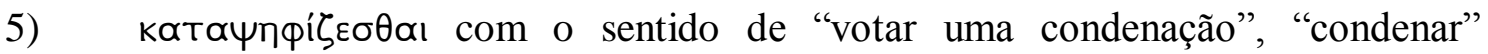

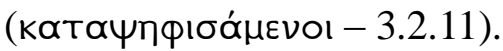

Há exemplos de palavras jônicas e do uso da poesia como:

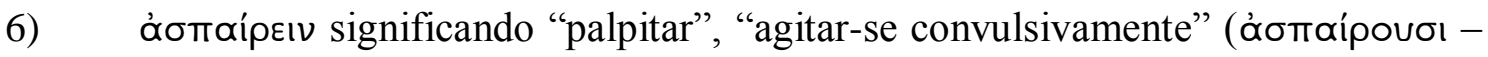
2.4.5). Um verbo também presente em Heródoto;

7) Eủoías: "bom tempo", "calmaria" (2.2.1);

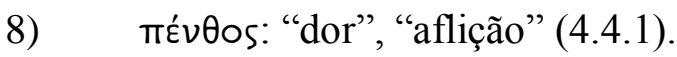

Ou, então, o uso de formas raras em ático, frequentes em Heródoto, como:

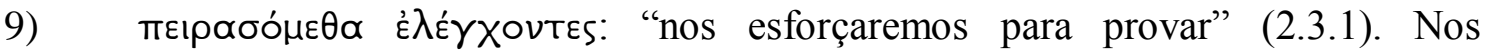
oradores, um infinitivo frequentemente segue тєıра́о $\mu a ̊$. Heródoto usa particípio, como aqui.

${ }^{103}$ Para o estudo lexical utilizamos, sobretudo, os dicionários de A.Bailly (grego-francês) e de LiddellScott (grego-inglês). 


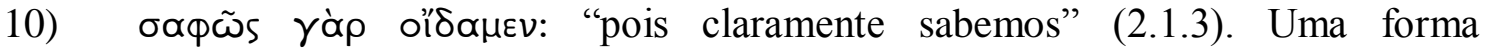
aparentemente jônica, encontrada também em Heródoto $(2.17,4.46,7.214,9.60)$ e em trabalhos hipocráticos. No período, seria pouco comum em ático. $\mathrm{O}$ comum seria $\mathrm{o}$

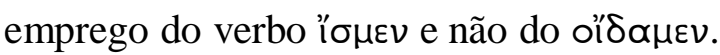

Dover, no artigo The Chronology of Antiphon's Speeches (1950), em que tenta estabelecer a cronologia dos discursos de Antifonte, sugere que, se as Tetralogias são autênticas, o emprego de palavras do dialeto jônico deveria ser um uso deliberado por parte de um ateniense que teria optado de modo consciente por palavras jônicas específicas ${ }^{104}$. A identificação, contudo, de uma palavra como sendo jônica nem sempre é segura. Gagarin ${ }^{105}$ e Decleva-Caizzi ${ }^{106}$ alertam, por exemplo, em suas respectivas

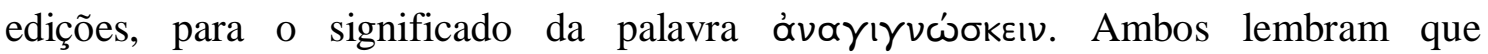
Harpócrates, no século II d.C., faz referências também a um texto de Iseu em que é encontrada a mesma palavra com o sentido de "persuadir". Por isso, não se pode dizer que esse sentido é apenas jônico. Talvez possa acontecer o mesmo com outras palavras. Apesar dessa dificuldade, o uso de palavras e formas jônicas não seria incomum no ambiente culto de Atenas, do qual faria parte Antifonte. Assim como não seria incomum Antifonte recorrer a palavras e formas encontradas em Heródoto e ser influenciado por ele.

\section{Vocabulário}

\section{Vocabulário da poesia:}

Por outro lado, certas palavras e construções empregadas nas Tetralogias podem ser identificadas como sendo exclusiva ou principalmente da poesia, muitas das quais comuns ao drama ático, outras emprestadas da épica. Mas assim como com relação ao uso de palavras jônicas, os comentadores dizem que a classificação dos termos como sendo próprias da poesia não é fácil de estabelecer. Não seria incomum, por exemplo, o uso de palavras emprestadas da Ilíada e da Odisseia, se, como afirma Cucuel ${ }^{107}$ em seu estudo sobre a linguagem e a elocução de Antifonte, toda a literatura grega procede de Homero. Entretanto, o que procuramos fazer, seguindo Cucuel, foi assinalar nas

\footnotetext{
${ }^{104}$ DOVER, 1950, p. 50.

${ }^{105}$ ANTIPHON, 1997, p. 132

${ }^{106}$ ANTIPHONTIS, 1969, pp. 184-85

${ }^{107}$ CUCUEL, 1886, p. 23
} 
Tetralogias certo número de palavras e expressões empregadas geralmente por poetas, mostrando que Antifonte não só não evitava como utilizava, em grande medida, essas expressões e construções para ornar sua elocução nesse estágio inicial da prosa ática. $O$ mesmo valendo para várias palavras importantes nas Tetralogias, que são provavelmente jônicas. Gagarin sugere que a incorporação desses modelos retirados da poesia por parte de Antifonte poderia ser um esforço consciente para dar a sua prosa, segundo ele, um tom mais artístico ${ }^{108} \mathrm{ou}$, em outras palavras, mais elevado; poderia ser uma escolha do autor e não uma necessidade, uma vez que outras palavras já existentes poderiam facilmente servir ${ }^{109}$.

Alguns exemplos mais evidentes são elencados abaixo:

1) Toıvท́: "punição" (2.1.3). Um termo arcaico cujo significado seria "vingança de sangue", "retaliação pela morte" ou "punição pelo crime de sangue", presente na Ilíada $9.633 ; 13.659 ; 14.483 ; 18.498$;

2) övarvov: "impuro" (2.1.10). Cf. Sófocle, Éd. Rei, v. 822; Éd. Col. v.944;

3) ớwpí: "hora avançada", "muito tarde” (2.2.5). Cf. Ésquilo, Eum. v. 957;

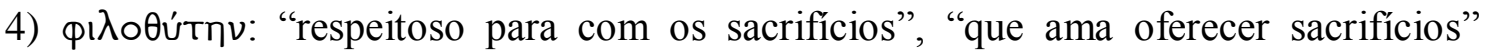
(2.2.12) Cf. Aristófanes, Vesp. v. 82; Ésquilo, Sept., v. 179;

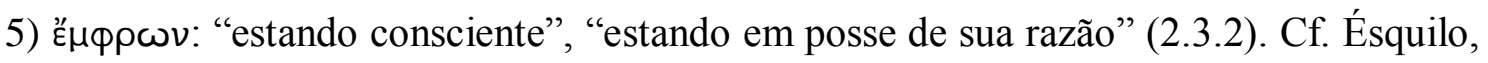
Prom., v. 848; Sófocles, Ant. v. 1237;

6) проотротая́ous: "espíritos vingadores" (2.3.10). Trata-se do "espírito de vingança do morto", a vítima não vingada que retorna para se vingar. Em prosa, ocorrem nas Tetralogias e em Ésquines (2.158). Cf. Ésquilo, Coéf. v. 269;

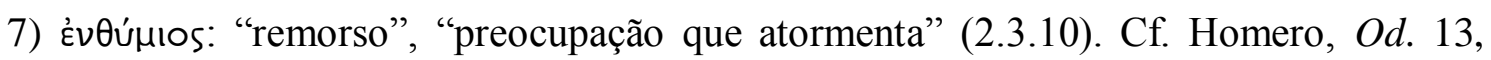
421; Sófocles, Tr. v.109; Éd. Rei, v. 739;

8) äonnos: "indiscernível”, "desconhecido", “obscuro" (2.4.8). Cf. Sófocles, Ant. v. 1209 ;

9) ớwpos: "prematura", "intempestiva" (3.1.2 e 3.2.12). Cf. Sófocles, Eum. v. 957;

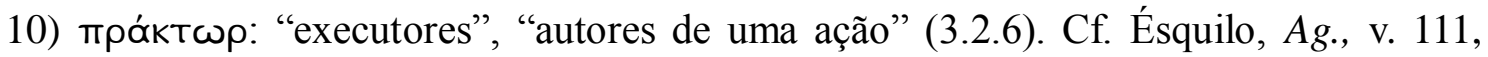
Eum., v. 319, Supl., v. 647; Sófocles, Tr. vv. 251 e 861, El. v. 953;

\footnotetext{
108 ANTIPHON, 1997, p. 25

${ }^{109}$ É importante ressaltar, contudo, que talvez o uso de um vocabulário específico, como esse comum à poesia, seja utilizado por Antifonte em razão do assunto por ele tratado. Por exemplo, ao lidar com o assunto do miasma, parece natural que o autor faça uso de termos e expressões a ele relacionados, tal

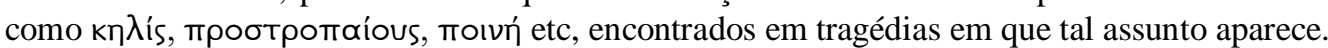




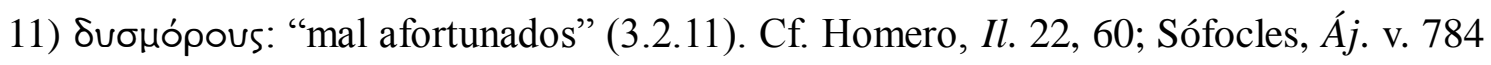
e Éd. Col. v. 1109;

12) vท́mıs: "menino" (3.2.11). Cf. Homero, Il. vv. 2, 136; 5, 480; 9, 440;

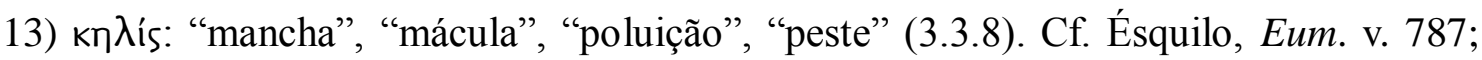

Sófocles, Éd. Rei. v. 833 e 1384, Éd. Col. v. 1134.;

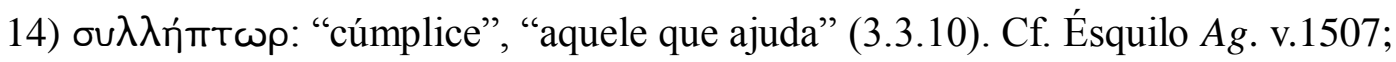

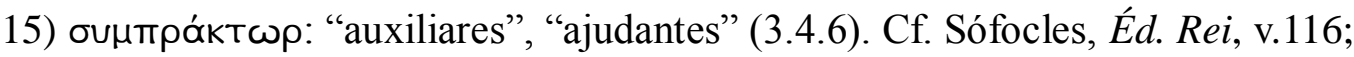

16) $\phi \tilde{u} \lambda \circ v$ : “espécie”, "linhagem” (4.1.2). Cf. Homero, Od. 14, 181; Il. 2, 840;

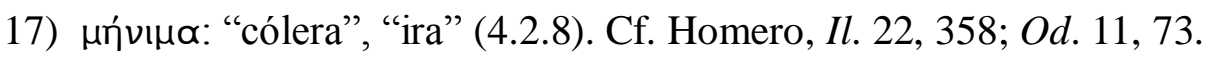

Ou exemplos de construções dramáticas ou recorrentes na poesia, frequentes na tragédia, podem ser encontradas em:

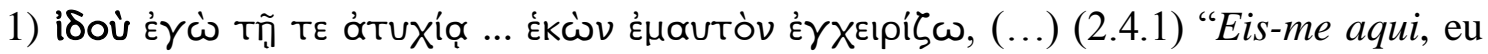
que, espontaneamente, me entrego ao infortúnio, (...)”. Uma expressão dramática ausente nos oradores; Cf. Sófocles, Fil. v.776, Tr. v.1079, Áj. v.870;

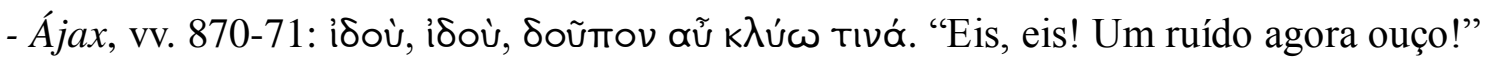
(Trad. de Flávio Ribeiro de Oliveira)

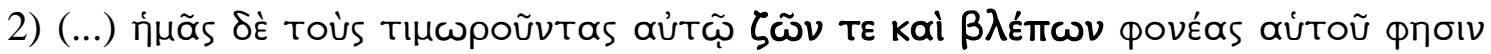
Eĩvaı (4.3.1). “(...) por outro lado, ele, que vive e vê [a luz], afirma que nós, os vingadores do morto, somos o assassino da vítima".

Uma expressão da poesia também encontrada em Ésquilo, Ag. vv. $676-77$ e Per., v.299:

- Agamêmnon, vv. 676-77:

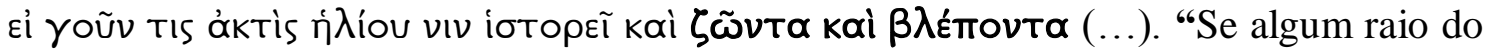
sol o observa vivendo e vendo a luz, (...)". (Trad. de Trajano Vieira).

- Persas, v. 299:

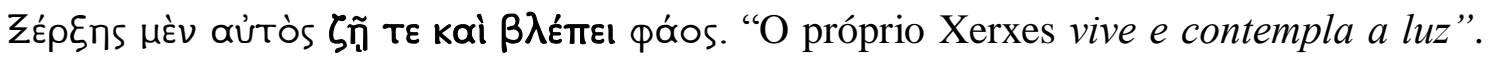
(Trad. Jaa Torrano).

Ou mesmo a elocução do proêmio do discurso da defesa na Tetralogia I em: 


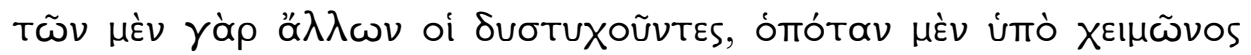

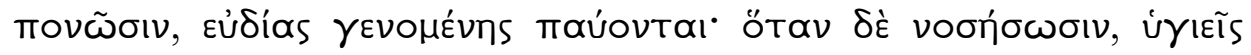

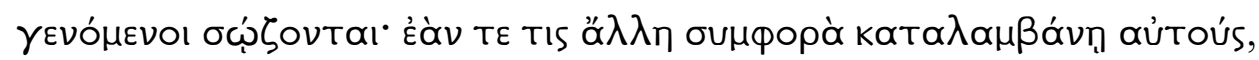

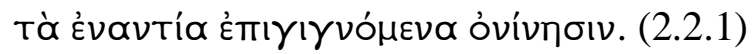

"Pois os demais desafortunados, sempre que sofrem com o mau tempo, encontram o repouso com a volta da bonança; e, sempre que adoecem, tornam-se saudáveis assim que recobram a saúde; também se alguma outra desgraça os atinge, as coisas adversas que se seguem são benéficas”.

A imagem da passagem do mau tempo para a bonança também está presente em

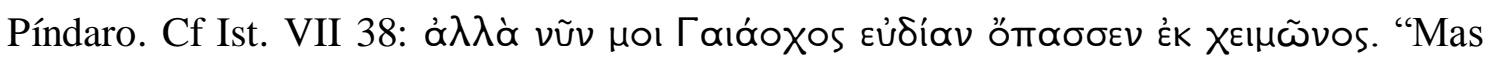
agora o deus-que-abraça-a-terra (Poseidon) enviou para mim o bom tempo depois da tempestade”.

Ou ainda o que alguns comentadores consideram ser uma ênfase dramática na

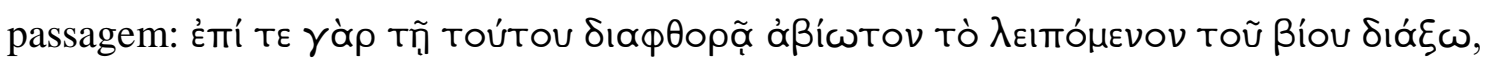
(...). (3.2.10) "Pois por causa da destruição de meu filho, levarei uma vida invivível pelos restos de meus dias".

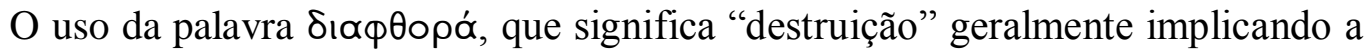
morte é, na opinião de Gagarin ${ }^{110}$ e Decleva-Caizzi ${ }^{111}$, um exagero intencional de Antifonte, uma ênfase patética e dramática, pois, em caso de condenação, a pena seria o exílio e não a morte, que é o que a palavra expressaria.

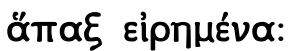

Além de recorrer à palavras e expressões jônicas e da poesia, Antifonte utilizaria, tanto nas Tetralogias quanto nos discursos para tribunal, palavras raras ou desconhecidas até então em dialeto ático, muitas das quais acredita-se ter seu uso inicialmente com o autor, haja vista que encontramos nas Tetralogias suas ocorrências mais antigas. Muitos dos prováveis neologismos criados por Antifonte são nomes (especialmente nomes abstratos) e palavras compostas (especialmente verbos compostos). São composições de palavras cujo radical já existia e que teriam por objetivo talvez suprir uma necessidade de um sentido preciso. Como sugere $\mathrm{Cucuel}^{112}$, o

\footnotetext{
${ }^{110}$ ANTIPHON, 1997, p. 152

${ }^{111}$ ANTIPHONTIS, 1969, p. 221

112 CUCUEL, 1886, p. 24.
} 
autor não hesitaria em criar palavras que poderiam responder melhor ao pensamento que gostaria de expressar.

Alguns exemplos de nomes encontrados nas Tetralogias provavelmente criados por Antifonte são:

1) (ó) ávatpomeús: “o destruidor” (2.2.2). A palavra (í) ơvatpomń (“destruição”) pode ser encontrada em Ésquilo, Eum. v.355.

2) Hı๔píav: "poluição", "mancha", "sujeira", "impureza", "nódoa" (2.3.1). Ocorrência mais antiga desse equivalente de $\mu$ ía $\sigma \mu \alpha$.

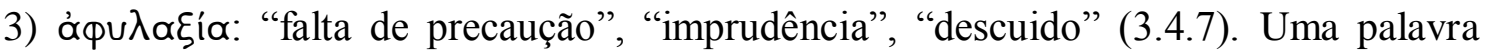
bastante rara, talvez criada por Antifonte.

4) đ’đeparteías: "falta de cuidados médicos" (4.3.5). Antifonte provavelmente cunhou o vocabulário anexando o $\alpha$ - privativo a $\theta \varepsilon p \propto \pi \varepsilon i ́ \alpha$.

5) ờıтńpıos: "espíritos infernais" (4.1.3). Um equivalente a тробтроткаíous. O uso da palavra com o sentido de "espíritos vingadores" seria bastante raro e ocorreria somente na Tetralogia III (4.1.3; 4.1.4; 4.2.8; 4.4.10), o que poderia talvez indicar que Antifonte, além de criar palavras novas, daria um sentido novo e pouco usual a palavras existentes.

A criação de novos verbos por Antifonte consistiria em acrescentar prefixos preposicionais a um radical já existente. Alguns exemplos de verbos compostos raros encontrados nas Tetralogias são:

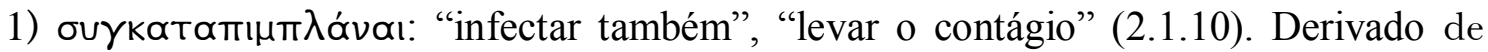
кататіі́тілнц.

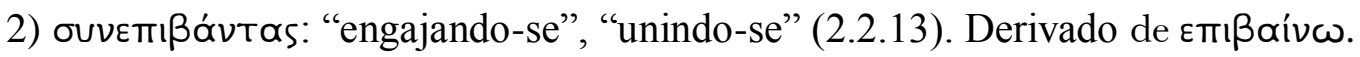

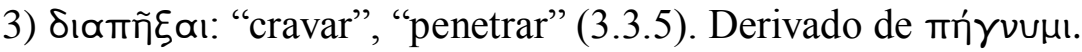

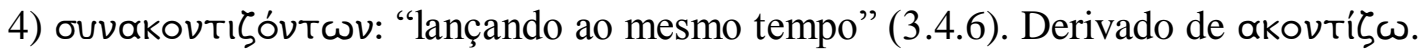

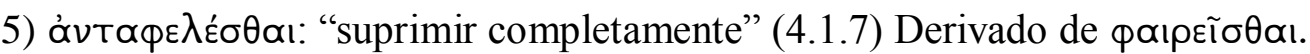

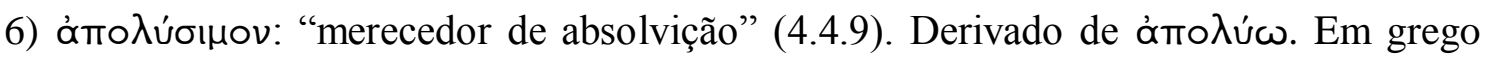
clássico, ocorre somente nesta passagem das Tetralogias e é bastante raro em autores posteriores.

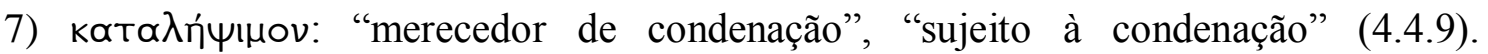
Derivado de kaт $\alpha \lambda \alpha \mu \beta a ́ v \omega$ significando "condenar". 


\section{Estrutura da frase: antítese e paralelismo}

\section{Antítese:}

Ao longo das três Tetralogias chama atenção o caráter antitético dos discursos. Vale lembrar que os críticos gregos, dentre os quais Aristóteles na Retórica (3.9.1-3 1409a 24-b8), reconheciam dois modos de elocução do discurso na prosa: o contínuo ou

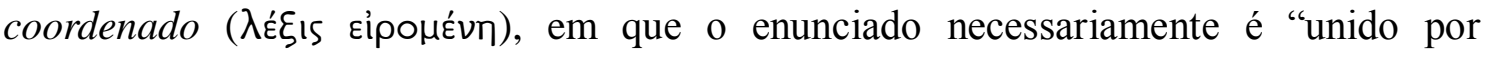
elementos coordenativos" (ARISTÓTELES, 1998, p. 193) e que "não tem fim em si mesmo, a não ser que o conteúdo expresso esteja concluído" (Ibid., p. 193); e o

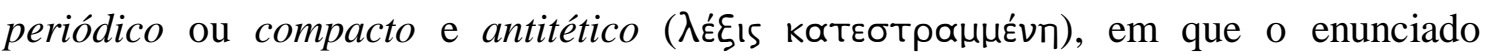
"possui princípio e fim em si próprio e uma dimensão fácil de abarcar com um só olhar" (Ibid., p. 193).

A elocução das Tetralogias é coordenada somente em um momento: no início da Tetralogia II, pois desenvolve-se uma narrativa. Trata-se da passagem em que a acusação descreve um fato:

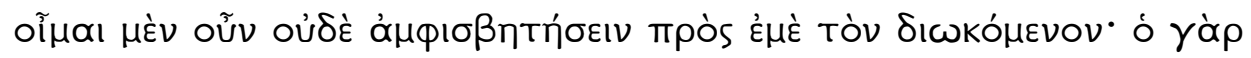

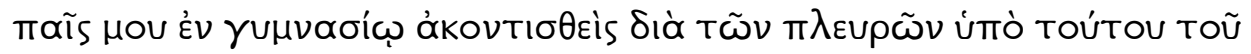

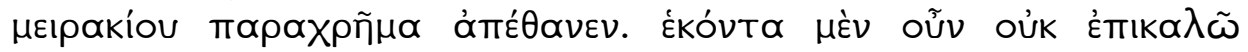

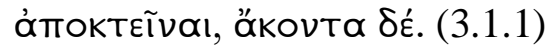

"Penso, com efeito, que o acusado não fará nenhuma contestação contra mim, pois, estando no ginásio, meu filho, ao ser atingido no meio de suas costas pelo dardo lançado por esse jovem, morreu de imediato".

Mas tão logo acaba essa pequena narrativa, o estilo dessa Tetralogia volta a ser antitético.

Denniston, na obra Greek Prose Style (1952), explica que é característico do pensamento grego visualizar uma ideia à luz dos opostos e que a antítese é um dos componentes da elocução da prosa grega ${ }^{113}$. Finley, por sua vez, em Three essays on Thucydides (1967), sugere que a construção antitética seria uma forma eficaz de isolar e esclarecer conceitos ${ }^{114}$, algo em voga na elocução do século V a.C. e notório, por exemplo, em Antifonte, Górgias e Tucídides. No caso de Antifonte, é evidente seu gosto pela construção antitética em especial nas Tetralogias.

No grego, o tradicional $\mu \dot{\nu} \nu$... $\delta \dot{\varepsilon}$ geralmente é utilizado para reforçar esse contraste de ideias. Antifonte recorre bastante a esta forma de contraste. No entanto, ele

\footnotetext{
${ }^{113}$ DENNISTON, 1952, p. 70
}

${ }^{114}$ FINLEY, 1967, p. 70. 
fará uso repetidamente do também tradicional oưk ... ờ $\lambda \lambda{ }^{\prime} \alpha$ ("não... mas") e, sobretudo,

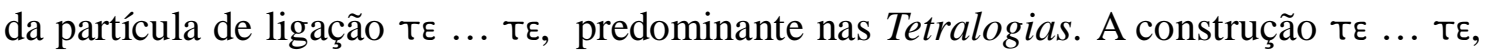
contudo, seria rara na prosa, mas bastante comum na poesia.

Podemos citar dois exemplos com $\mu \dot{\nu}$... $\delta \dot{~ q u e ~ i l u s t r a m ~ b e m ~ u m ~ c a s o ~ d e ~}$ estrutura antitética frequente nas Tetralogias, um deles um caso de antítese em que são posicionados em lados opostos conceitos, como observado por Finley. Um primeiro exemplo, na passagem:

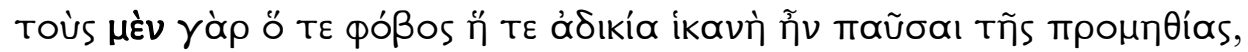

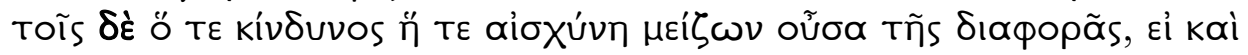

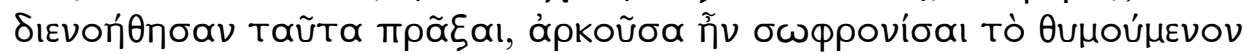

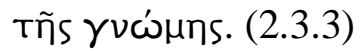

"Pois, enquanto nestes, o medo e a injustiça sofrida seriam suficientes para fazer cessar a precaução; naqueles, o risco e a desonra, sendo maiores do que a desavença, seriam suficientes para moderar o ânimo irado, ainda que tivessem em mente realizar essas ações”.

Um segundo exemplo, na seguinte passagem:

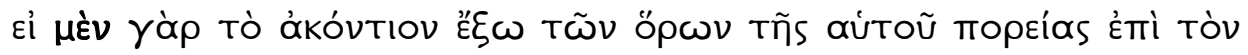

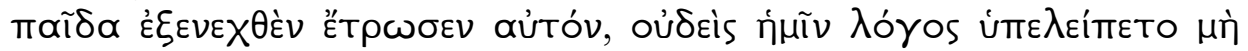

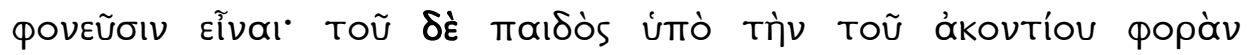

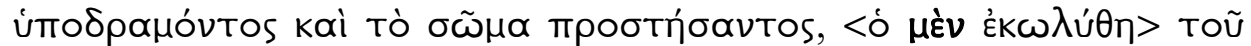

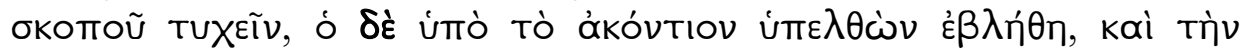

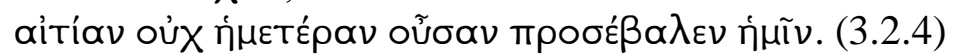

"Pois se a lança, fora dos limites de seu próprio curso, tivesse sido lançada contra o garoto e o tivesse ferido, nenhum argumento teria restado para nós senão o de sermos os assassinos. No entanto, dado que o garoto correu sobre os limites da trajetória da lança e frente a ela posicionou seu corpo, enquanto esta não alcançou sua meta, aquele, porque avançou sobre sua trajetória, foi atingido, de modo que, embora a responsabilidade não seja nossa, ele a lançou contra nós".

Nesse período há o contraste entre a situação em que a culpa seria do lançador e a que ele apresenta como fato, a ação do garoto apresentada como imprudente. Havendo nesta última outra antítese. Isso mostra que não são recursos desnecessários, pois, como aqui, essas antíteses servem tanto para a defesa quanto para a acusação de seu oponente.

Quanto aos exemplos de contraposição com oúk ... ò $\lambda \lambda \lambda_{\alpha}$, alguns podem ser

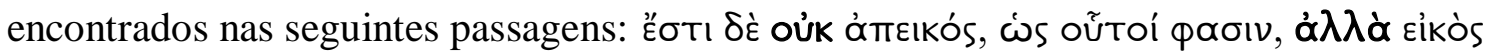
(...) (2.2.5). "Não é pouco razoável, como eles dizem, mas razoável que (...)”; e em: (...) 


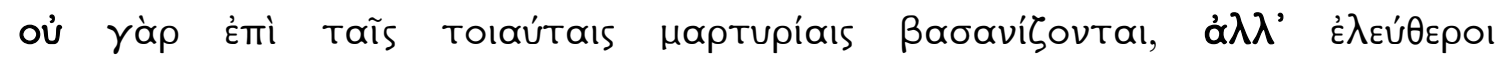

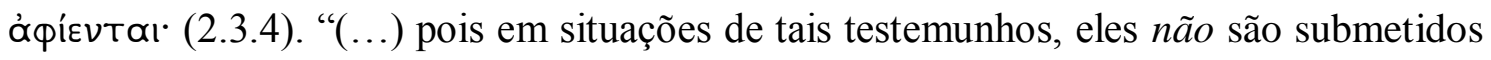
à tortura, mas são deixados livres".

Já a construção $T \varepsilon \ldots T \varepsilon$, usada para ligar fortemente dois termos ou "orações dos quais se deseja ressaltar o paralelismo" (RAGON, 2011, p. 278), aparecem em: Пॅ тє

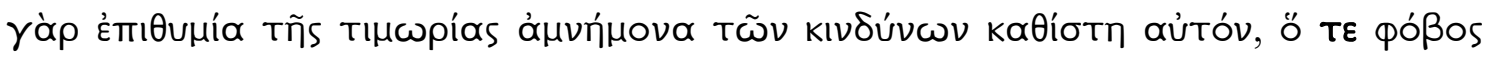

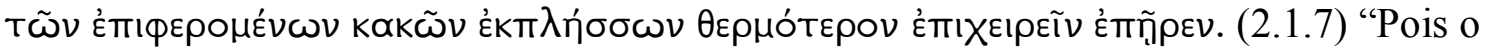
desejo de vingança o fez esquecer os riscos $e$ o medo dos males que o ameaçavam, por

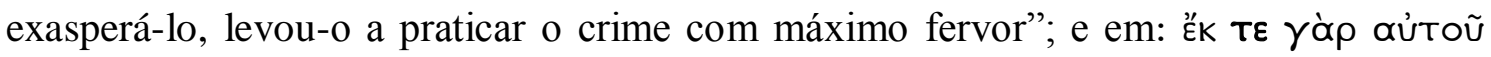

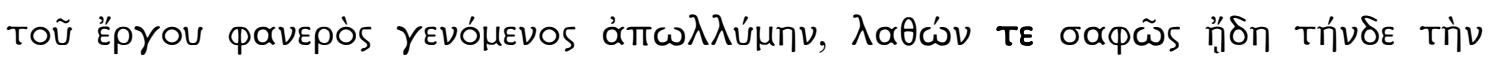

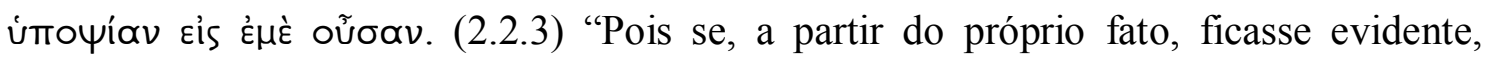
estaria completamente perdido; $e$ se eu não fosse notado, saberia claramente que essa suspeita recairia sobre mim".

Não raro Antifonte utiliza mais de uma fórmula em conjunto, como ocorre em um parágrafo em que o autor emprega os três casos:

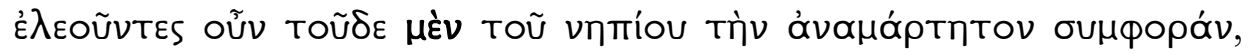

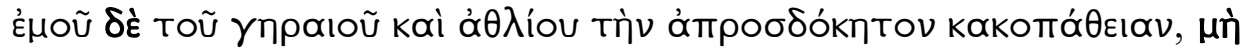

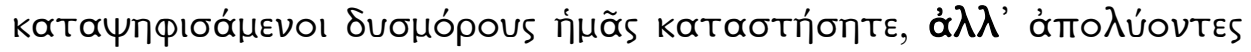

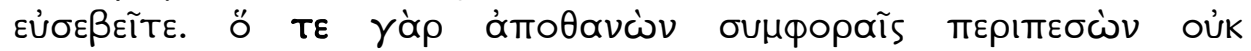

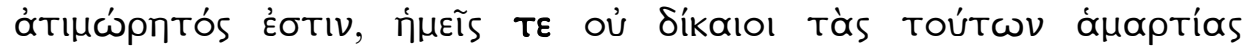

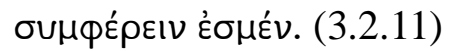

"Apiedando-se, então, desse menino, que é inocente nessa desgraça, e de mim, um velho homem e miserável, em meu sofrimento inesperado, não nos tornem mal afortunados após votarem nossa condenação, mas sejam piedosos nos absolvendo. Pois o garoto morto não está sem vingança pela desgraça que lhe sobreveio $e$ não é justo que nós carreguemos os seus erros".

Na passagem referida, é possível notar três pares antitéticos: filho e pai, condenação e absolvição, vítima e defesa.

\section{Paralelismo:}

Antifonte constantemente reforça as ideias contrastantes com alguns paralelismos, cujo efeito se encontra frequentemente na sonoridade.

O paralelismo do tipo homoiotéleuton, caracterizado pela similaridade de

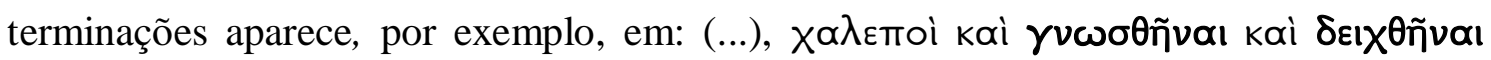


Eỉol, (...). (2.1.1). “(...) são difíceis de serem desmascarados e incriminados (...)”; e em

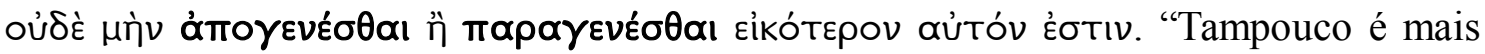
razoável que o acusado estivesse ausente do que presente”.

Nas duas frases ocorre a similaridade das terminações dos dois infinitivos,

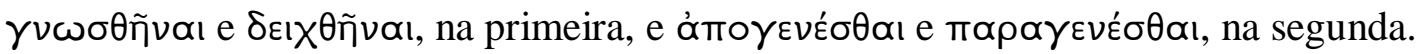

Um paralelismo do tipo paromoíosis, caracterizado pela similaridade dos sons de

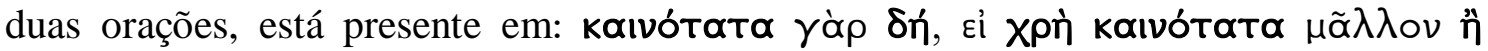

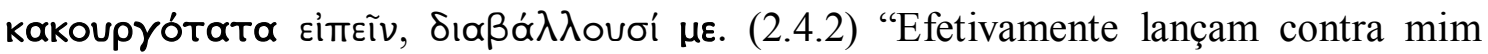
acusações caluniosas as mais inauditas - as mais inauditas para não dizer as mais malditas".

Um paralelismo do tipo parísosis, caracterizado pela similaridade da dimensão

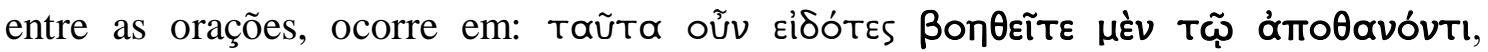

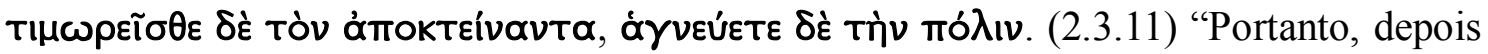
de saberem isso tudo, socorram o morto, castiguem o assassino e purifiquem a cidade".

Um paralelismo do tipo isócolon é usado por Antifonte na Tetralogia III para reforçar uma antítese entre um homem mais novo e um homem mais velho. Esse paralelismo é caracterizado por possuir o mesmo número de sílabas. No trecho em questão, é possível encontrar seis expressões paralelas sem variação.

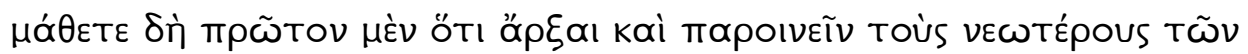

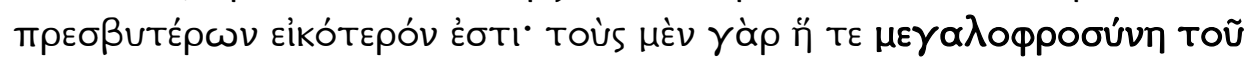

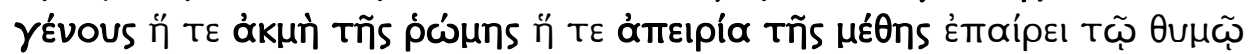

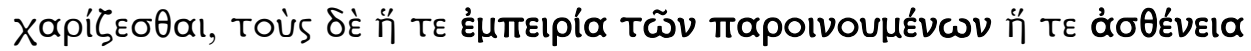

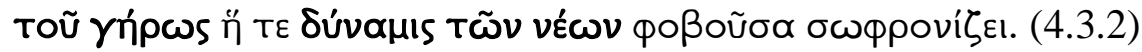

"Primeiramente, saibam vocês que é mais razoável que os mais jovens e não o mais velhos comecem [uma agressão] e fiquem embriagados, pois enquanto aos primeiros a arrogância natural, a plenitude da força física e a falta de perícia com os excessos de bebida os incitam a ceder à cólera, aos últimos a experiência com os excessos de bebida, a debilidade da velhice e o temor pela força dos jovens os fazem moderados".

Ou um caso de poliptoto, que consiste na repetição de uma palavra, no caso

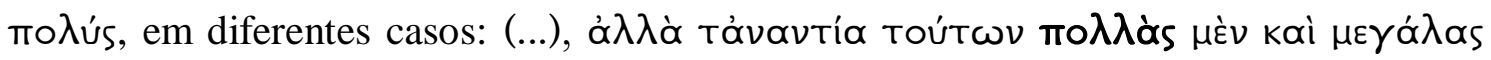

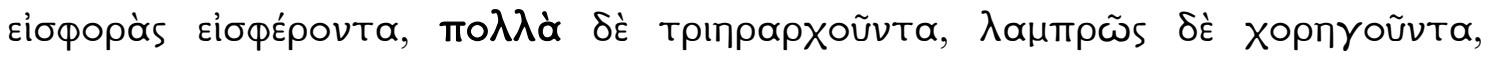

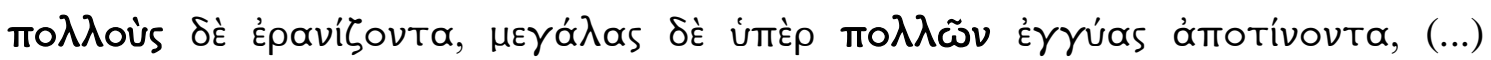
(2.2.12). “(...) mas, ao contrário, tenho fornecido muitas e substanciosas contribuições, 
desempenhado muitas vezes a função de trierarca, exercido brilhantemente a coregia, ajudado muitos com empréstimos e garantido em favor de muitos grandes cauções, (...)".

\section{Sintaxe}

Do ponto de vista da sintaxe, outros dois procedimentos são importantes para a elaboração da elocução de Antifonte nas Tetralogias: a perífrase e o uso de particípios.

\section{Perífrases:}

É comum Antifonte utilizar a perífrase (ou circunlocução) no lugar de um verbo descritivo. Nas Tetralogias, a construção perifrástica consiste geralmente de um nome ou um adjetivo ou um particípio e um verbo. Por exemplo:

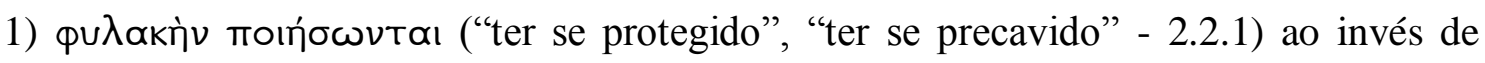

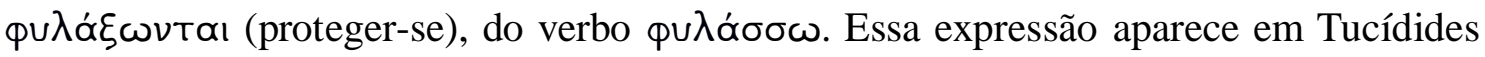
(3.46);

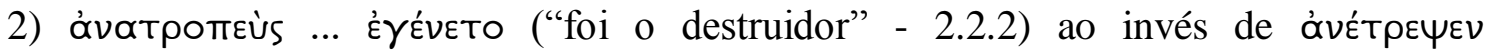

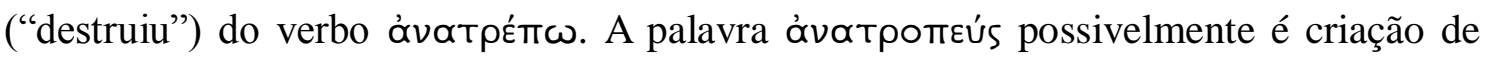
Antifonte;

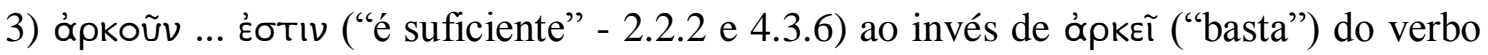

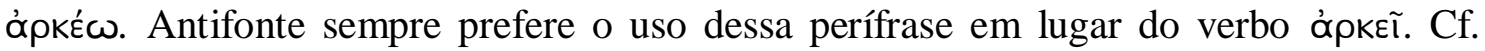

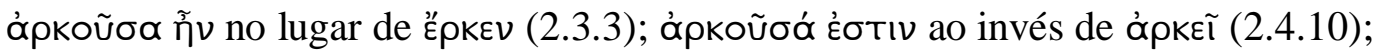

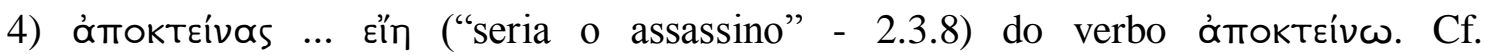
ámoктвívas....el̄ (3.4.4). Caso raro de perífrase com particípio aoristo.

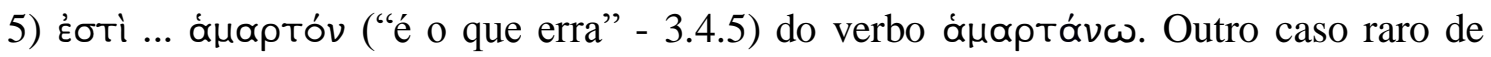
perífrase com particípio aoristo.

De acordo com alguns comentadores de Antifonte, a perífrase teria uma função precisa. Cucuel, por exemplo, não acredita que essas perífrases tivessem por objetivo inserir na frase apenas um efeito pitoresco ${ }^{115}$. Segundo ele, haveria entre uma perífrase e um verbo simples uma nuança bem distinta: o verbo simples exprime um fato; a perífrase, um estado que dura, uma situação desejada, a qual se torna, de certa maneira, um dos modos de ser daquilo de que se fala ${ }^{116}$. Gagarin, por sua vez, defende que, na maioria dos casos, o efeito buscado pelo uso de tal construção seria o de reforçar a

\footnotetext{
115 CUCUEL, 1886, p. 25.

${ }^{116}$ Ibid., p. 25
} 
atenção sobre um estado de causa que pode ser analisado ao invés de uma ação que seria simplesmente narrada ${ }^{117}$.

\section{Particípios:}

Por fim, são especialmente comuns nas Tetralogias particípios com artigo e, sobretudo, particípios adverbiais, ou seja, particípios que equivalem a uma oração circunstancial. O elevado número de particípios, que lembra a prosa de Tucídides, de quem acredita-se que Antifonte tenha sido professor ${ }^{118}$, contribui para a grande complexidade sintática das Tetralogias.

Dois exemplos mais simples, utilizados por Gagarin para ilustrar um caso de acúmulo de particípios (com artigo e com função de uma oração adverbial) em torno de um verbo principal simples, podem ser notados na passagem que se segue: ú $\mu$ ãs $\delta \dot{\varepsilon}$

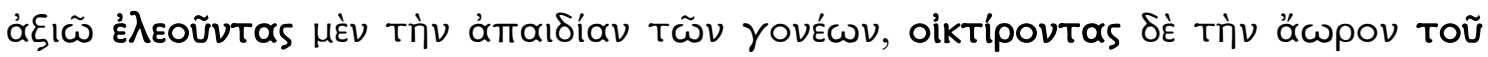

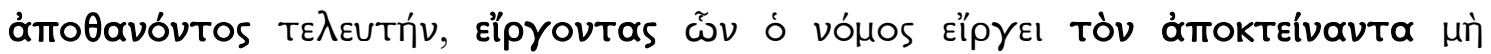

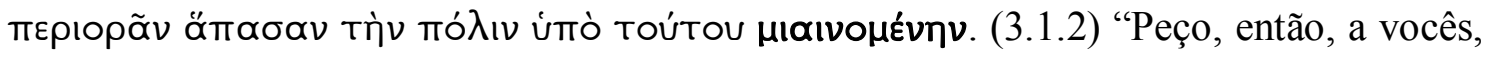
que, apiedando-se dos pais privados de seus filhos e compadecendo-se do fim prematuro da vítima, expulsem o assassino dos lugares de onde a lei expulsa e não permitam que a cidade toda seja contaminada por ele".

E em:

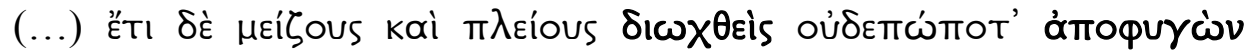

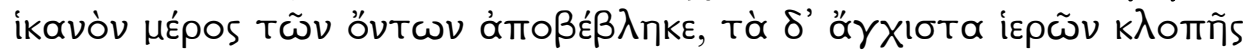

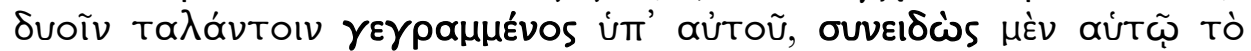

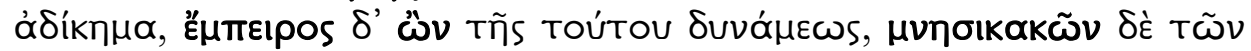

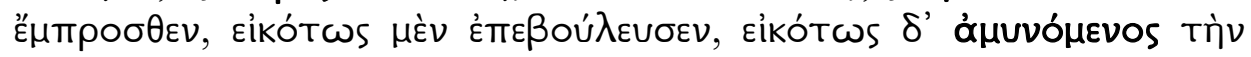

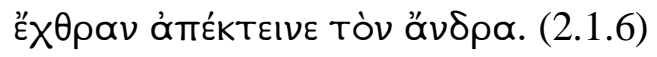

“(...); tendo sido acusado ainda em muitos e graves processos, não sendo jamais absolvido, tem perdido parte significativa de seus bens; e muito recentemente foi apresentada pela vítima uma acusação pública de roubo de objetos sagrados cuja multa é do valor de dois talentos. Sabendo-se culpado, tendo experiência da capacidade do seu oponente e lembrando as ofensas antes sofridas, é razoável supor que tramou um plano e que, ao se prevenir da hostilidade, assassinou o homem".

\footnotetext{
117 ANTIPHON, 1997, p. 29

${ }^{118}$ Já na antiguidade, acreditava-se que Antifonte tivesse sido professor de Tucídides. De acordo com o testemunho de Hermógenes, em De ideis 2.11 [A.2 DK/A.2 U/T2 P] "muitos dizem que Tucídides foi aluno de Antifonte de Ramnunte"; no Suda (Antiphôn a 2744-46, 1.245 Adler), também há a menção de que Antifonte fora professor de Tucídides; e Pseudo-Plutarco, na Vida dos Dez Oradores, nos informa que Cecílio acreditava que Tucídides tivesse sido aluno de Antifonte pelos elogios que o historiador lhe fazia.
} 
Um exemplo mais complexo, utilizado por Dover, pode ser encontrado em:

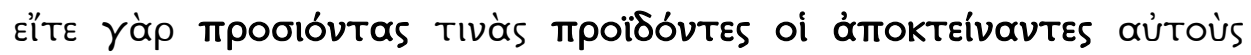

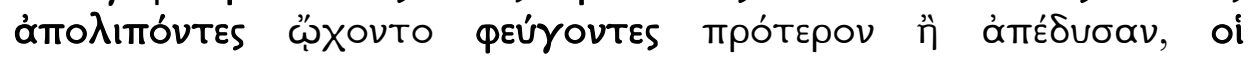

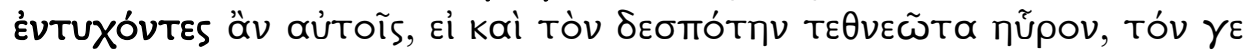

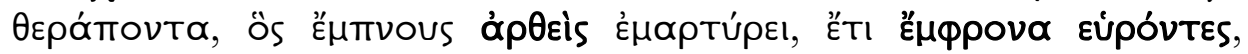

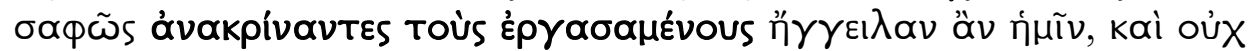

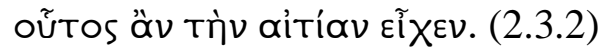

"Pois se os assassinos, vendo que algumas pessoas se aproximavam, abandonaram o senhor e o escravo e partiram em fuga antes de roubar suas roupas, então os que tivessem se deparado com os dois, mesmo se encontrassem o senhor morto, teriam encontrado o escravo consciente e ainda respirando e podendo testemunhar; se eles tivessem interrogado exaustivamente, teriam anunciado para nós os realizadores da ação e este aqui não teria a culpa".

Os elementos apresentados acima e que constituem a elocução da prosa de Antifonte nas Tetralogias, diferem, a saber, dos discursos compostos para serem efetivamente apresentados em um tribunal. Os elementos de elocução neles encontrados são distintos dos empregados nas Tetralogias, em grande medida, dada a natureza desses discursos de tribunal. Ao contrário das Tetralogias, são compostos com uma sintaxe muito mais simples e com elementos típicos da apresentação oral, como o pleonasmo ou a repetição, o anacoluto ou a inconsistência sintática; não são discursos marcados pelos experimentos com a linguagem nem pela complexidade dos argumentos trabalhados nos discursos hipotéticos. Essas, e outras divergências, também acabaram contribuindo para se duvidar da autenticidade das Tetralogias. É importante, no entanto, levar em conta as diferenças de propósitos das Tetralogias e dos discursos para tribunal, o público ao qual eram dirigidos esses discursos e a época de suas composições.

\subsection{Sobre a edição grega}

A respeito da transmissão do texto, dois são os manuscritos principais: o Crippsianus ou Burneianus 95 (A), do século XIII, e o Oxoniensis $(N)$, escrito no início do século XIV. Há outros manuscritos, mas todos bastante posteriores a $A$ e $N$ : o Laurentianus (B), o Marcianus (L), o Burneianus 96 (M) e o Vratislauiensis (Z). Tanto o 
manuscritos $A$ quanto $N$ teriam sido corrigidos por seus próprios escribas $\left(A^{l}\right.$ e $\left.N^{I}\right)$, e então posteriormente por escribas diferentes $\left(A^{2}\right.$ e $\left.N^{2}\right)$. Ambos são bastante semelhantes. As edições mais antigas publicadas são a de Aldo Manuzio (Veneza, 1513) e Henri Estienne (Paris, 1575). Na edição de 1575, estabeleceu-se a em umeração convencional dos discursos em 1, 5 e 6 para os discursos de tribunal e 2, 3 e 4 para as Tetralogias.

A presente tradução baseia-se principalmente no texto grego estabelecido por Michael Gagarin na sua edição comentada Antiphon, The Speeches, de 1997. Essa edição, de acordo com o próprio autor, em geral, aproxima-se da de Decleva-Caizzi (Itália, 1969). Por isso a edição italiana comentada de Fernanda Decleva-Caizzi Antiphontis Tetralogiae, de 1969, com poucas alterações em comparação com a edição inglesa de Gagarin, também foi particularmente útil para a presente tradução. Para as notas, seguimos, na maioria das vezes, os comentários de Decleva-Caizzi e de Gagarin, e as notas das traduções de K. J. Maidment (inglesa, de 1953), de Louis Gernet (francesa, de 1954) e de Jordi Redondo Sánchez (espanhola, de 1991). As notas que seguem o texto grego visam tanto apontar as emendas ou adições realizadas por editores anteriores e seguidas por Gagarin, quanto identificar aqueles elementos que são característicos do estilo de Antifonte nas Tetralogias. Com as notas inseridas na tradução pretendemos explicar alguns aspectos legais, literários, históricos e filosóficos, e, sobretudo, as passagens em que a argumentação se torna mais complexa ou de difícil compreensão. 


\section{TEXTOS, TRADUÇÕES E NOTAS DAS TETRALOGIAS}

\subsection{Texto, tradução e notas da Tetralogia I [2]}

\section{$2.1^{119}$}

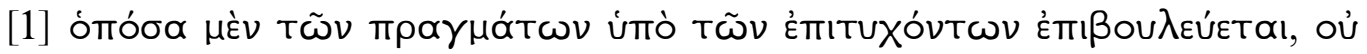

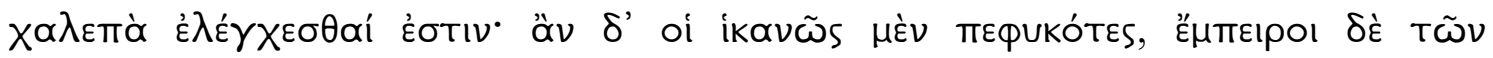

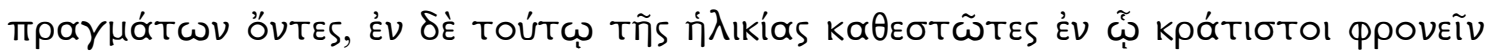

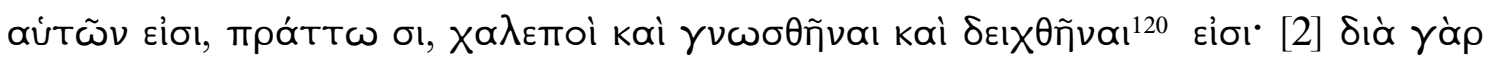

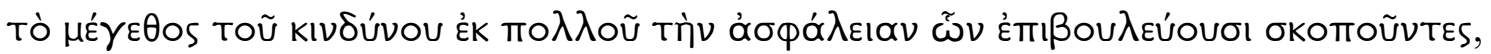

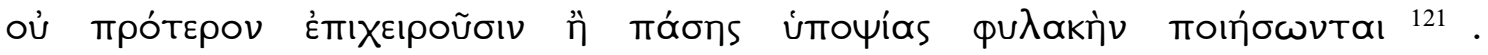

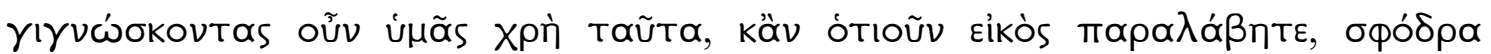

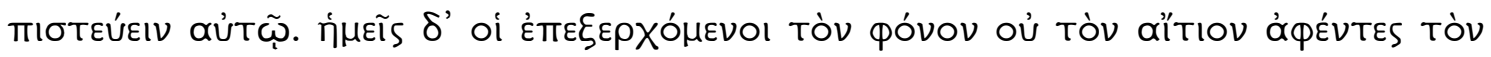

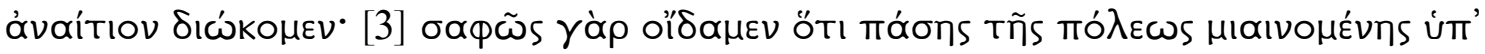

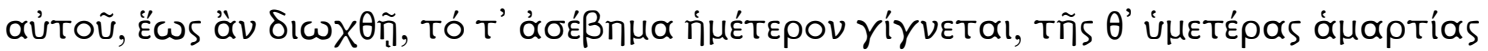

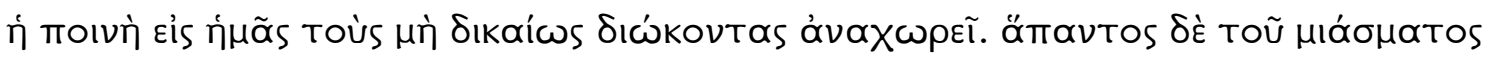

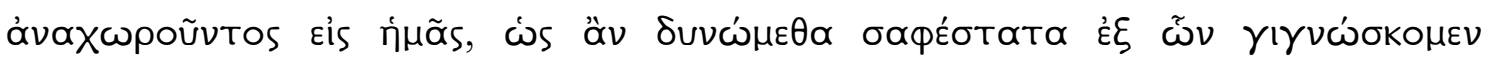

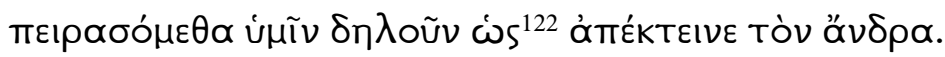

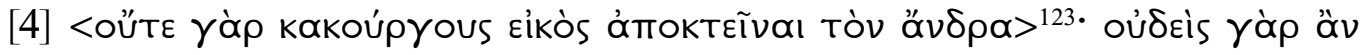

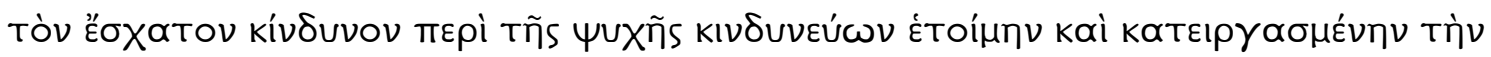

\footnotetext{
${ }^{119}$ Seguimos a edição de Michael Gagarin. Nela não é inserida a hypothesis, a breve introdução para os casos, criada em um período posterior a Antifonte. Nas edições em que ela é inserida (Gernet e Maidment, por exemplo), é comum encontrar no post hypothesim a seguinte inscrição: katnyopía póvou àmapó́onnos (Acusação de homicídio anônimo). Optamos a indicação em umérica de Gagarin, que segue edições anteriores que estabelecem a ordem dos textos da seguinte maneira: Contra a madrasta, por

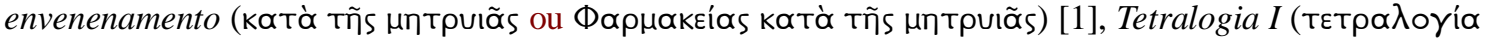

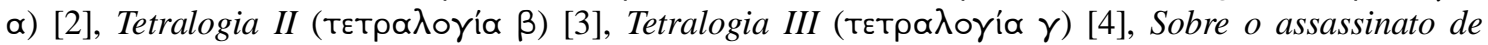

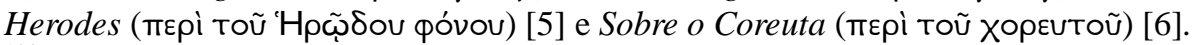

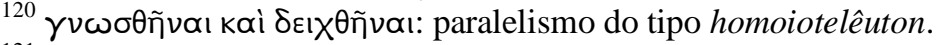

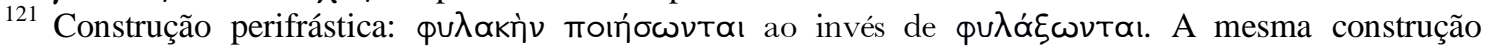
também pode ser encontrada em Tucídides na História da Guerra do Peloponeso, 3.46.4: кai tìv

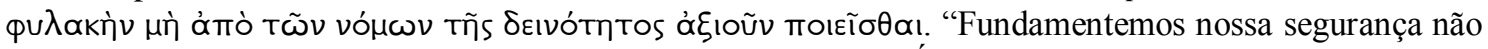
na rigidez de nossas leis, mas no cuidado com nossos atos" (TUCÍDIDES, 1987, p.179).

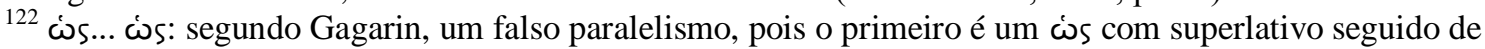
um verbo de poder, enquanto o segundo é uma conjunção (ANTIPHON, 1997, p. 126).

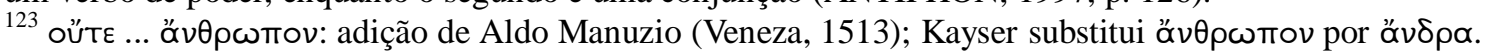
Enquanto Gagarin opta pela adição da frase, Decleva-Caizzi a suprime.
} 


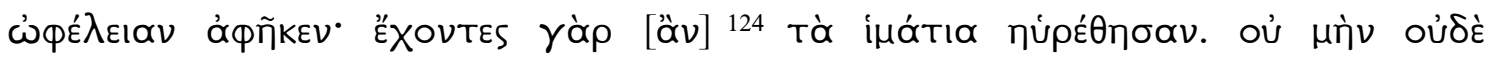

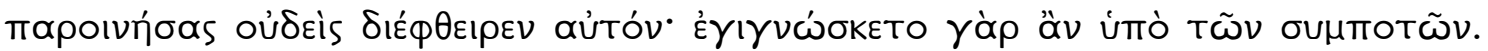

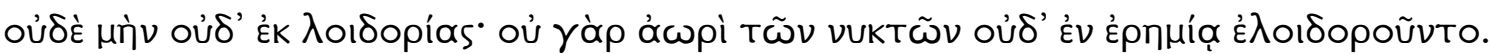

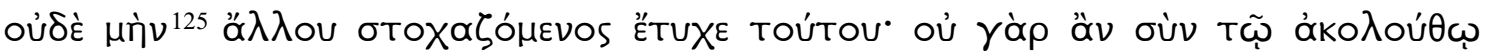

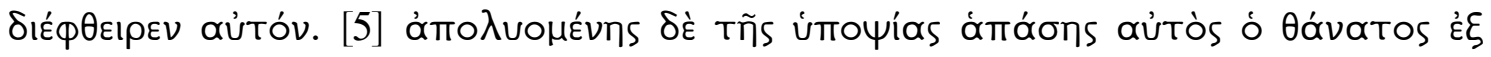

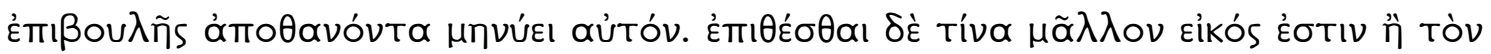

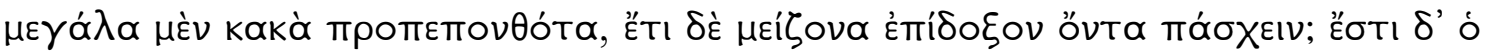
$\delta ı \omega k o ́ \mu \varepsilon v O S$ oŨTos

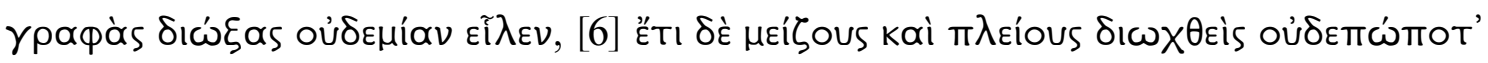

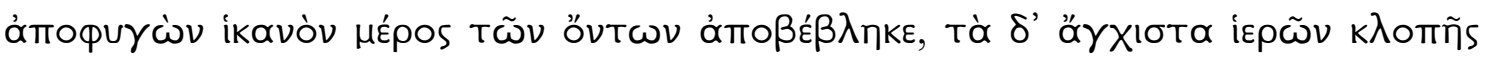

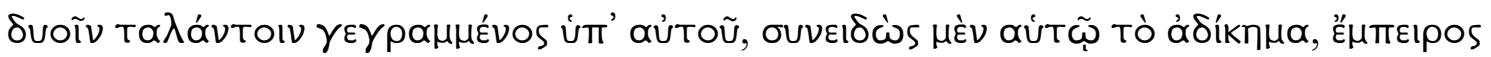

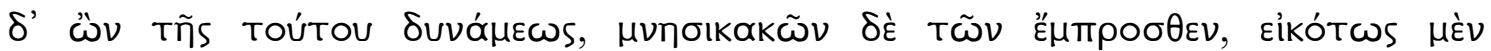

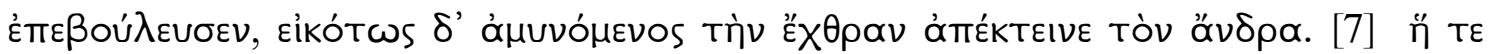

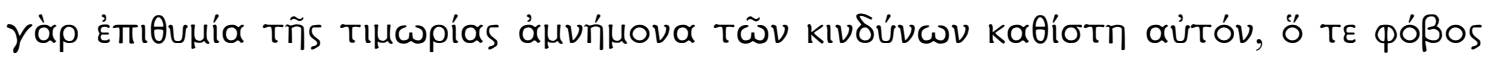

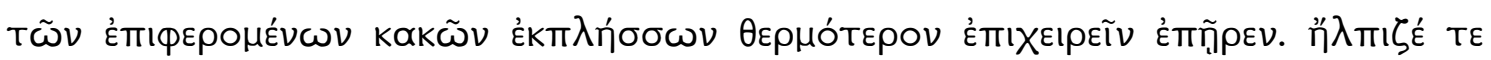

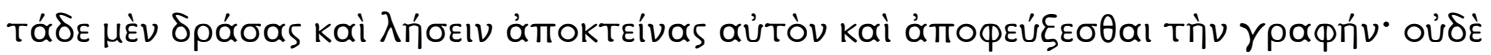

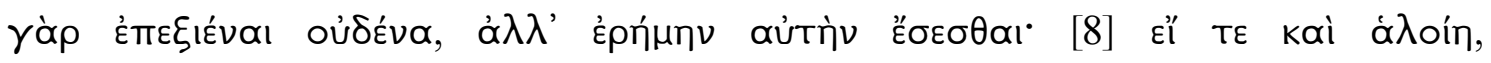

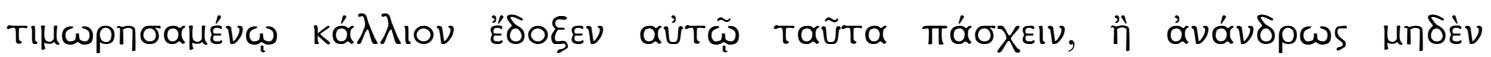

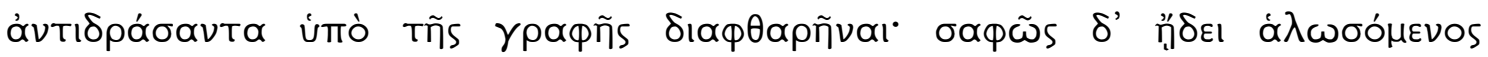

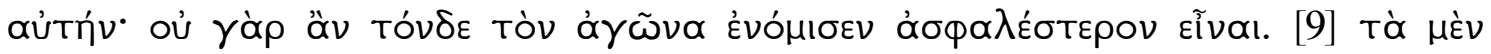

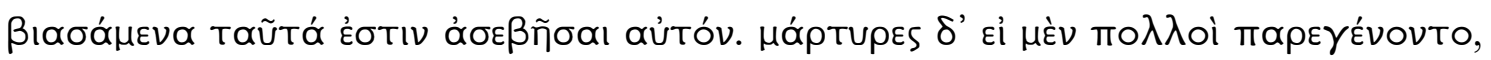

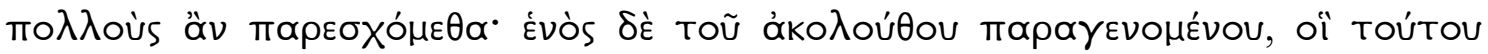

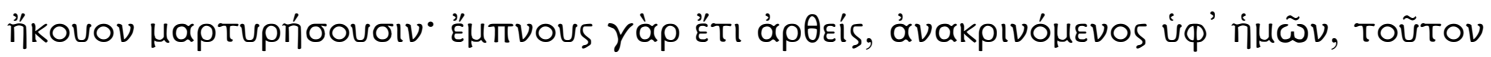

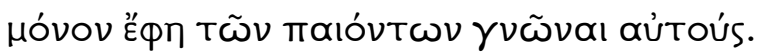

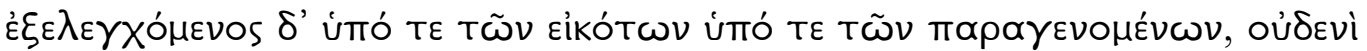

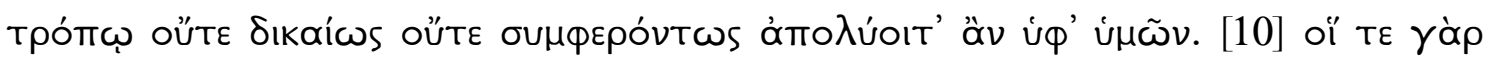

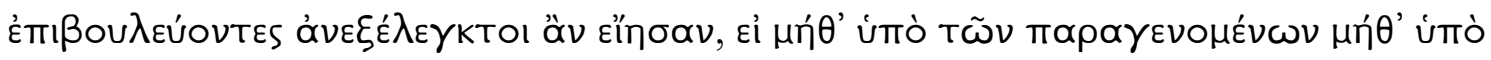

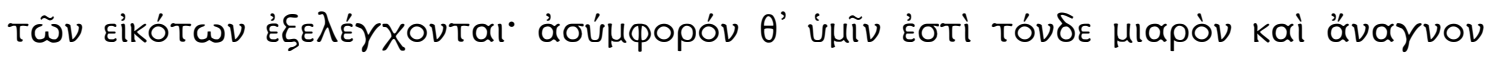

\footnotetext{
124 à $v$ : suprimido do texto por Reiske (Leipzig, 1773). Gagarin opta por mantê-lo entre colchetes, embora também defenda que seja eliminado do texto, uma vez que as vítimas foram encontradas com suas roupas.

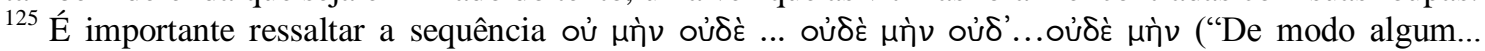
Tampouco... de modo algum...”), que seria única na prosa clássica.
} 


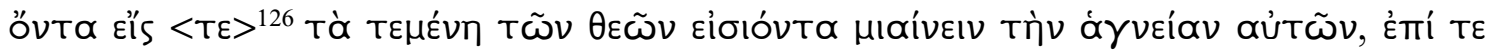

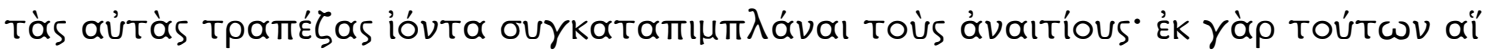

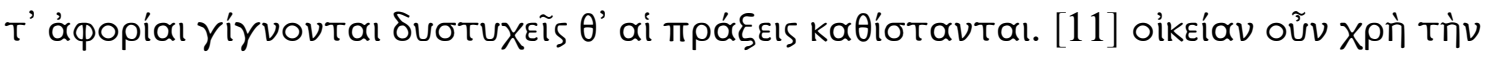

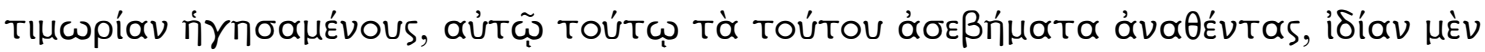

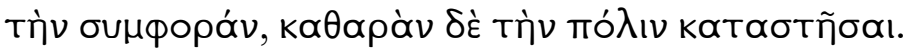

\section{1}

[1] Quando os crimes são planejados por homens comuns ${ }^{127}$, não é difícil encontrar a prova; mas se, por outro lado, os autores são homens naturalmente habilidosos e experimentados nessas ações, e estão naquele ponto de sua vida em que são superiores para pensar, estes são difíceis ${ }^{128}$ de serem desmascarados e incriminados. [2] Pois, em virtude do imenso risco envolvido, ao examinarem por um longo tempo a segurança do que planejam, não agem antes de terem se precavido de toda suspeita possível. Portanto, compreendendo vocês essas coisas, ainda que aceitem qualquer argumento como plausível (Eíkós) ${ }^{129}$, convém acreditar totalmente nisso. Quanto a nós, que apresentamos a acusação de homicídio, não acusamos um inocente deixando livre o culpado. [3] Pois sabemos claramente que, estando a cidade inteira contaminada pelo assassino, até que este seja acusado a impiedade torna-se nossa e a punição ${ }^{130}$ pelo erro dos senhores recai sobre nós se não acusamos de modo justo ${ }^{131}$. Por se voltar contra nós todo o miasma, tentaremos mostrar a vocês, o mais claramente possível, a partir do que conhecemos, que ele matou o homem.

\footnotetext{
${ }^{126}$ Tع: adição de Blass (Leipzig, 1881), que Gagarin preserva, apesar de não achar necessário.

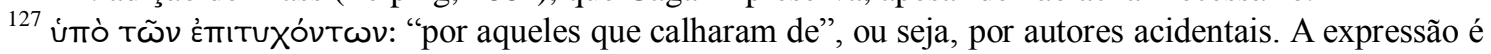

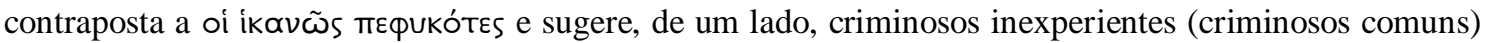
e, de outro, experientes e habilidosos.

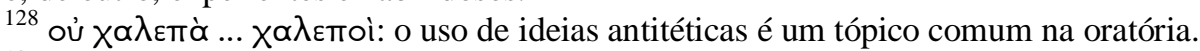

129 Eikós: no período clássico, o termo comportaria o sentido de "expectativa razoável" com relação à conduta humana: o que se supõe que um homem deve naturalmente fazer. Em português, os termos geralmente usados são "provável", "verossímil", "lógico", "natural", "plausível", "razoável". Na Tetralogia I, procuramos traduzi-lo, no mais das vezes, por "plausível" e "razoável", por acreditar que, neste discurso, o Eíkós, empregado como um contraponto à evidência direta, comporta o sentido daquilo que é socialmente adequado ou esperado, embora também faça referência àquilo que é semelhante ao verdadeiro ou que tem qualidade de verossimilhança. Esses dois significados poderiam ser encontrados em discursos do século V a.C. Tanto o sentido quanto o papel desempenhado pelo argumento do eíkós, serão melhor analisados no comentário da Tetralogia $I$.

${ }^{130}$ moıvń: termo arcaico cujo significado seria "vingança de sangue", "retaliação pela morte" ou "punição do crime de sangue". Cf. Ilíada 9.633; 13.659; 14.483; 18.498.

${ }^{131}$ Acerca da responsabilidade religiosa do acusador, há uma passagem análoga em 4.1.4.
} 
[4] <Pois bem, não é plausível (Eỉkós) que assaltantes ${ }^{132}$ tenham matado o homem>, pois ninguém que tivesse corrido riscos tão extremos para sua vida teria deixado escapar um ganho ${ }^{133}$ certo e já obtido, haja vista que as vítimas foram encontradas de posse de suas roupas. De modo algum alguém que estivesse embriagado o matou, pois este teria sido reconhecido por aqueles que bebiam com ele. Tampouco foi morto por causa de uma briga, pois não teriam brigado em uma hora avançada da noite e em lugar deserto. E de modo algum aconteceu de alguém tomar a vítima por outra, pois não a teria eliminado junto com seu escravo ${ }^{134}$. [5] Sendo toda suspeita removida de outros suspeitos, a circunstância da própria morte ${ }^{135}$ indica que o homem

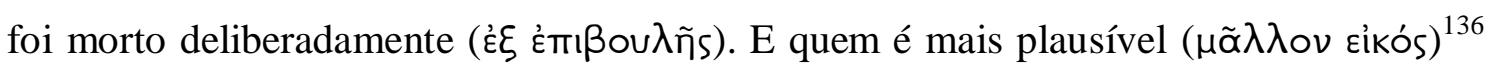
que tenha atacado a vítima senão aquele que sofrera os maiores prejuízos e que espera sofrer ainda mais ${ }^{137}$. O acusado, então, é este. Pois, sendo, desde muito, inimigo da vítima, não obteve vitória em nenhuma das inúmeras e graves acusações públicas ${ }^{138}$ que apresentou contra ela; [6] tendo sido acusado ainda em muitos e graves processos - sem jamais ser absolvido - , vem perdendo parte significativa de seus bens; e, muito recentemente $^{139}$, foi apresentada pela vítima uma acusação pública de roubo de objetos sagrados cuja multa é do valor de dois talentos ${ }^{140}$. Ciente de sua culpa, tendo

\footnotetext{
${ }^{132}$ kakoũpyos: em Atenas, termo técnico para "ladrão", "salteador" ou "assaltante". Maidment e Gernet traduzem o termo grego por "malfeitores" (malefactors e malfaiteurs, respectivamente); Morrison, por "criminosos profissionais" (professional criminals); Gagarin, por "criminosos comuns" (common criminals). Nesta passagem, optamos por traduzir kakoúpyous por "assaltantes" já que faz referência ao roubo de vestimenta.

${ }^{133} \omega \dot{\phi \varepsilon ́} \lambda \varepsilon ı \alpha v:$ "ganho", "benefício" ou "lucro"; referência à vestimenta ou alguma peça de roupa da vítima.

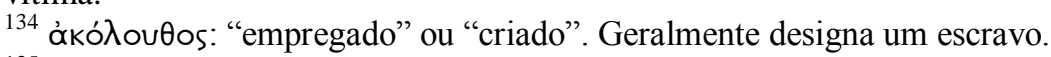

135 aưròs ó Đóva tos: "a própria morte". Maidment e Gagarin traduzem por "a circunstância da morte" (circumstances of death). Morrison traduz por "a maneira como se deu a própria morte" (the manner of the death itself). As circunstâncias da morte levam a acusação a anunciar que se trata de um homicídio deliberado ou premeditado.

${ }^{136} \mu \tilde{\alpha} \lambda \lambda$ 入 $\vee$ Eikós: esta construção pode ser encontrada apenas nesta passagem e em 2.2.6.

${ }^{137}$ Uma pergunta retórica.

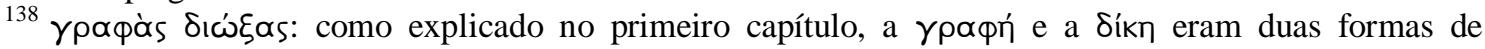

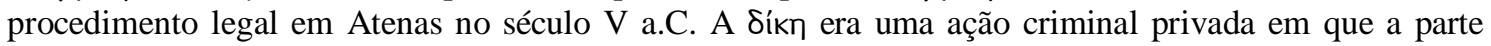
lesada (ou seu parente, em caso de homicídio) apresentava o processo contra quem o lesou; a y $p \alpha \varphi n ́$ era uma ação criminal pública.

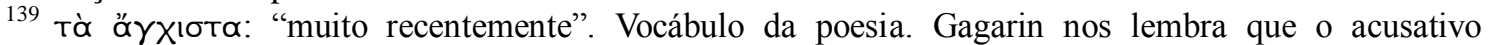
adverbial é comum na tragédia grega. Na prosa clássica, pode ser encontrado aqui, em Antifonte, em Heródoto (II, 143) e nos escritos do corpus hipocráticos.

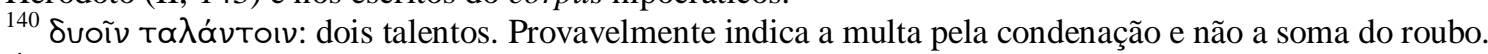
É difícil buscar uma equivalência entre a unidade monetária da Grécia Clássica e a atual. Mas, seguindo a explicação de Gagarin, a unidade básica da moeda ateniense era o dracma, que seria dividido em seis óbolos. Para elevadas somas, uma mina consistia de 100 dracmas e um talento de 60 minas ou 6.000 dracmas (ANTIPHON, 1997, p. 13). Desse modo, dois talentos consistiriam em 120 minas ou 12.000 dracmas, o que parece ser uma quantia considerável. Na nota de suas traduções, tanto Gernet quanto
} 
experiência da capacidade de seu oponente e lembrando as ofensas antes sofridas, é razoável supor (Eíkótws) que ele tenha tramado um plano ${ }^{141}$ e que, ao se prevenir da hostilidade, tenha assassinado o homem. [7] Pois, enquanto o desejo de vingança o fez esquecer os riscos, o medo ${ }^{142}$ dos males que o ameaçavam, por exasperá-lo, levou-o a praticar o crime com máximo fervor. Ainda que tivesse feito tudo isso e tivesse matado esse homem, ele ainda tinha esperança de não ser notado e de escapar da acusação de roubo ( $\left.\gamma \rho \alpha \varphi v^{\prime}\right)$, pois ninguém o acusaria de nada e o caso, por falta de acusação, seria abandonado. [8] E mesmo se ele fosse apanhado, pareceu-lhe mais valoroso sofrer essas coisas tendo se vingado do que ser covardemente destruído ${ }^{143}$ pela acusação de roubo (Ypapriv) sem nada fazer ${ }^{144}$. Ele claramente sabia que seria condenado por essa acusação, pois não teria considerado que a presente disputa fosse mais perigosa. [9] Esses são os motivos que obrigaram o réu a cometer uma impiedade. Se estivessem presentes muitas testemunhas, muitas nós teríamos apresentado; visto que apenas uma estava presente, o escravo, aqueles que o ouviram testemunharão ${ }^{145}$. Pois o escravo foi encontrado ainda respirando ${ }^{146} \mathrm{e}$, ao ser interrogado por nós, afirmou que, daqueles que os agrediram, reconheceu somente o acusado.

Sendo declarado culpado tanto pelas plausibilidades quanto pelas testemunhas ${ }^{147}$, de modo algum, seja conforme a justiça seja conforme o vantajoso, o réu poderia ser absolvido por vocês. [10] Pois os que planejam crimes não poderiam ser condenados se não fossem declarados culpados nem pelas testemunhas nem pelas plausibilidades. Não é vantajoso para vocês que este homem, estando impuro e ímpio, profane a santidade dos santuários dos deuses ao adentrá-los e leve o contágio aos inocentes sentando-se com eles à mesma mesa. Pois, a partir disso, a terra se torna estéril ${ }^{148} \mathrm{e}$ os negócios,

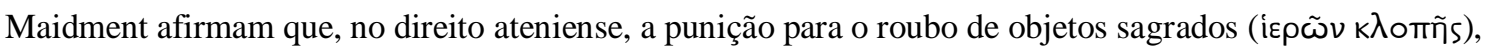
uma $\gamma \rho \alpha \varphi n ́$, seria a restituição ou reembolso dez vezes mais o valor desviado, no caso, do objeto roubado. Cf. Demóstenes, Contra Timócrates, 111, 112, 127.

${ }^{141}$ Isto é, planejou o crime; a acusação reforça a ideia da premeditação do crime.

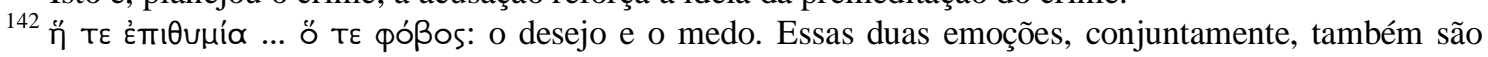
usadas por Górgias em Elogio de Helena, 16-17 e Defesa de Palamedes, 19.

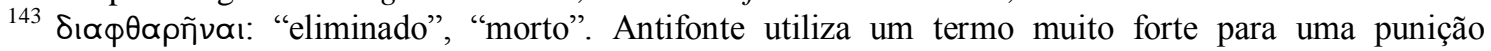
monetária.

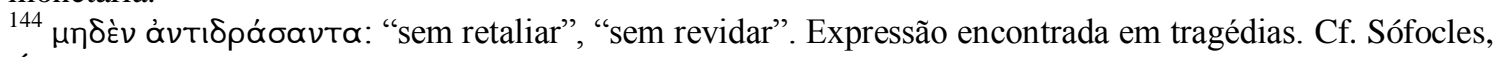
Éd. Col. v. 271, 953, 959, 1191; Eurípides, Andr. v. 438 e Supl. v. 1179.

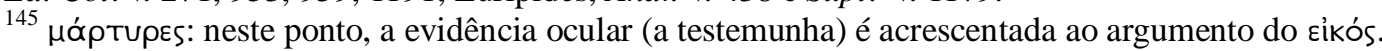

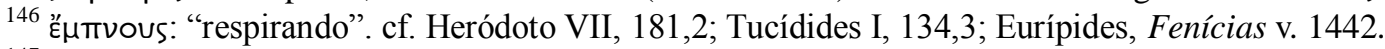

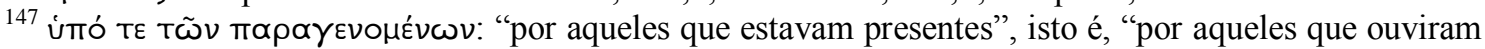
do escravo".

${ }^{148}$ Gagarin comenta que não há exemplos na história ou nos mitos de ơi ó фopóåı, ou seja, de infertilidade da colheita como resultado de um homicídio comum. (ANTIPHON, 1997, p.130) Decleva-Caizzi, 
desafortunados. [11] Portanto, depois de considerarem a vingança em seu próprio interesse e restituírem ao próprio criminoso a sua impiedade, cabe a vocês deixar a desgraça a quem convém e a cidade livre das impurezas.

\section{$2.2^{149}$}

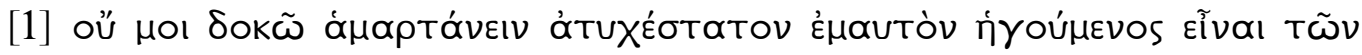

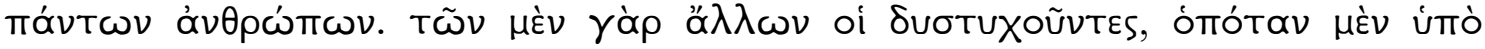

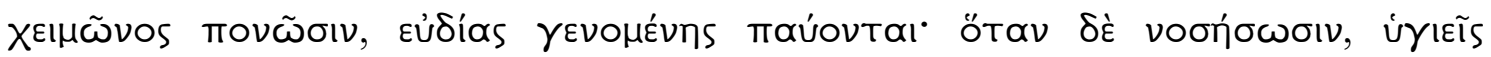

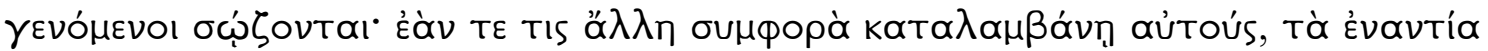

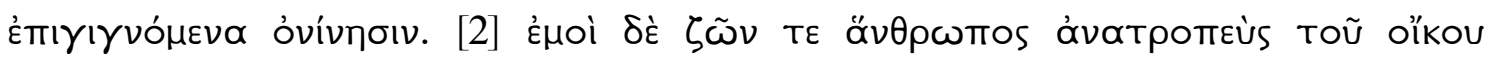

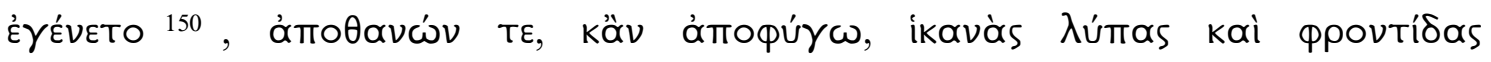

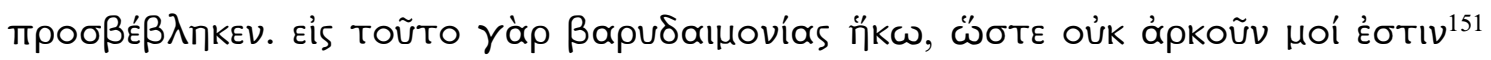

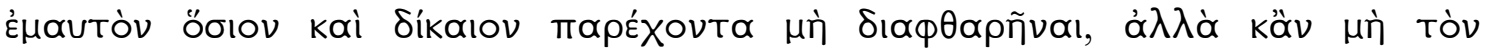

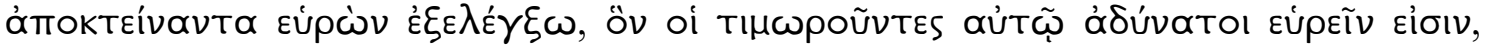

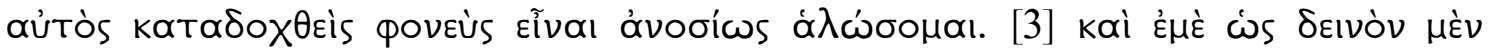

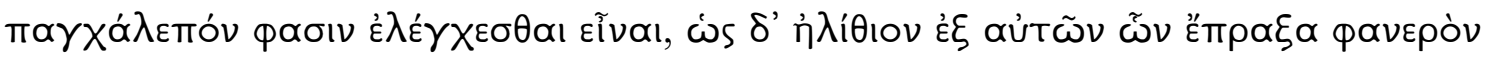

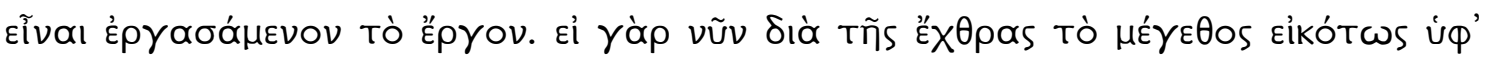

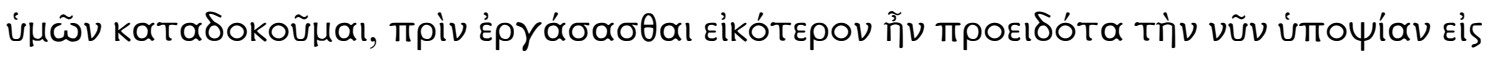

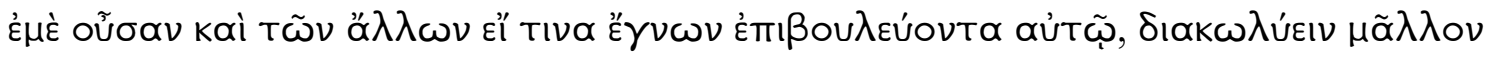

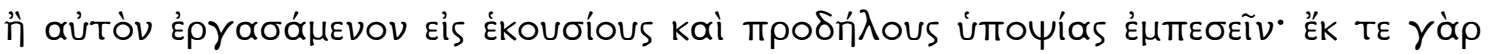

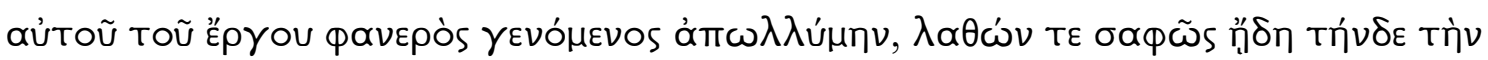

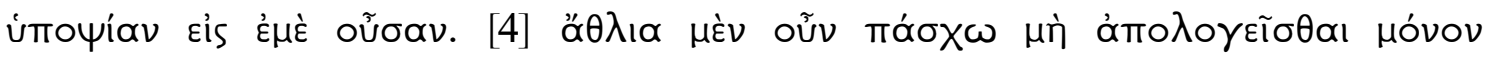

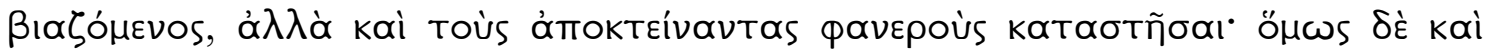

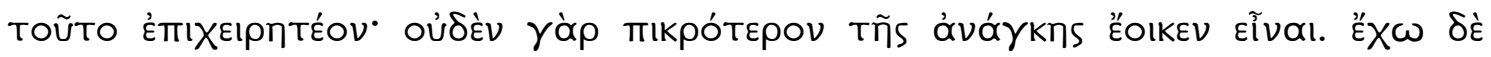

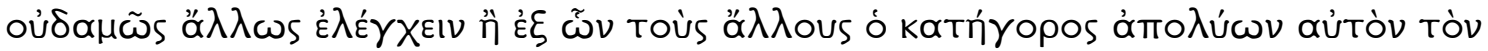

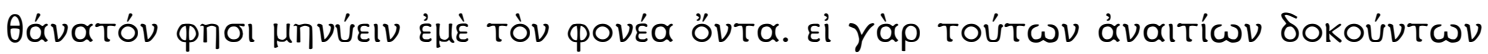

contudo, alerta para uma passagem do Édipo Rei v. 254, em que Édipo faz referência a uma "terra sem fruto, sem deus, sem vida, sem nada", caso acolha conscientemente o assassino de seu pai em seu palácio. (ANTIPHONTIS, 1969, p. 179)

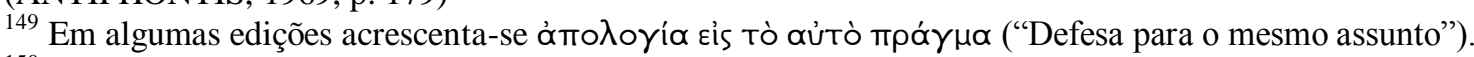

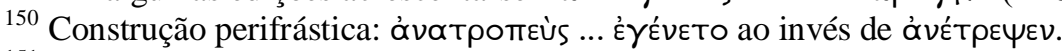

${ }^{151}$ Outra construção perifrástica: à 


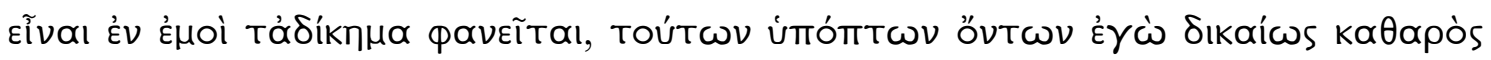
Sokoínv عĩval.

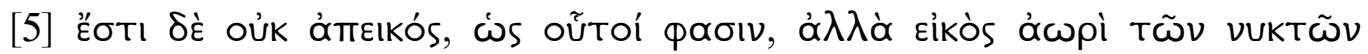

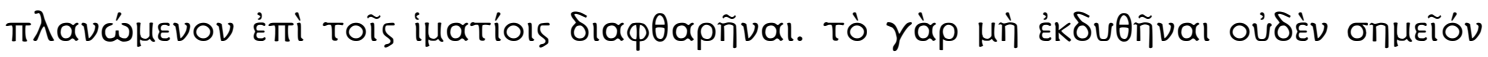

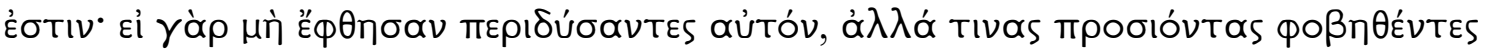

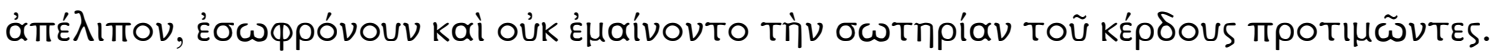

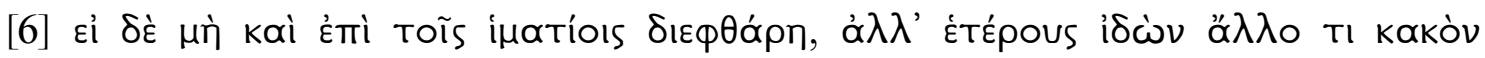

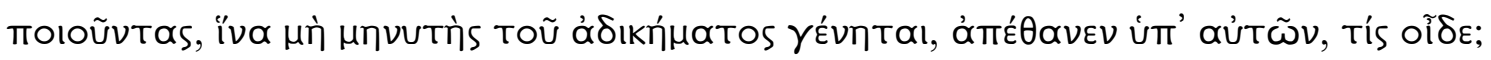

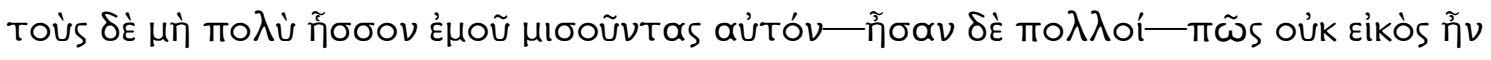

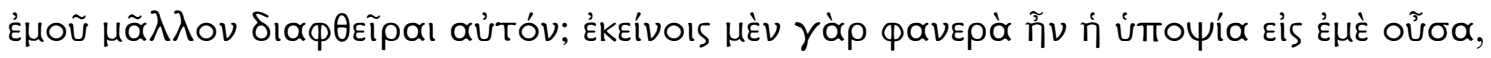

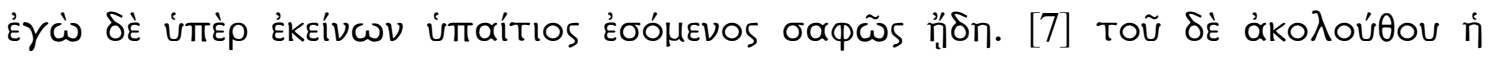

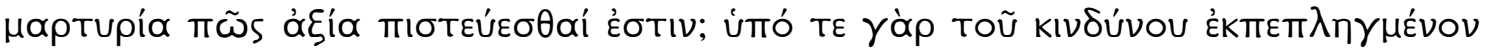

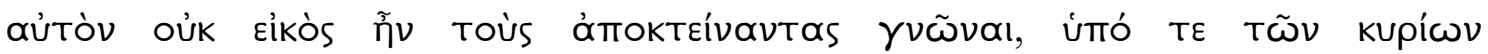

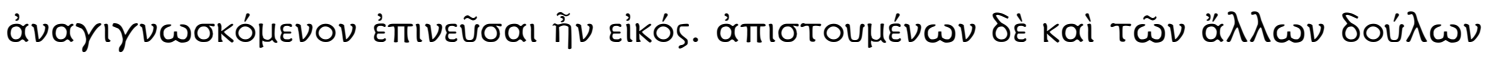

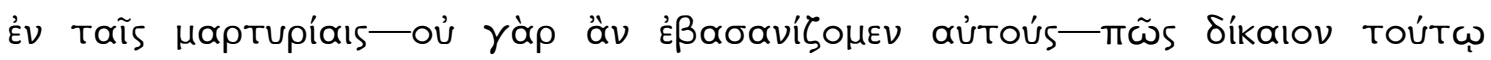

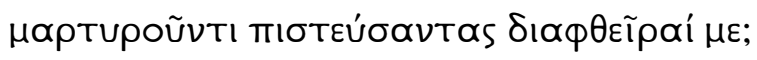

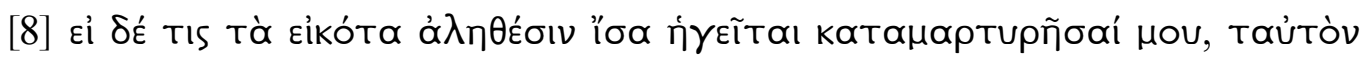

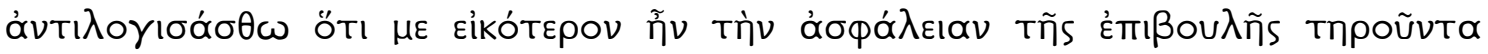

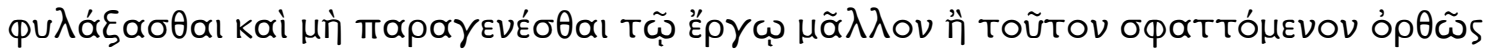

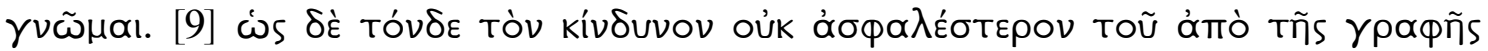

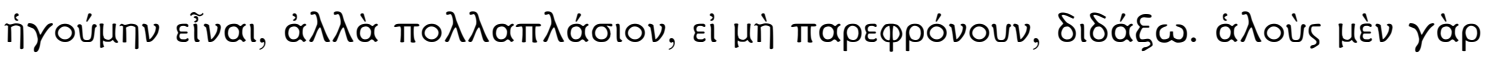

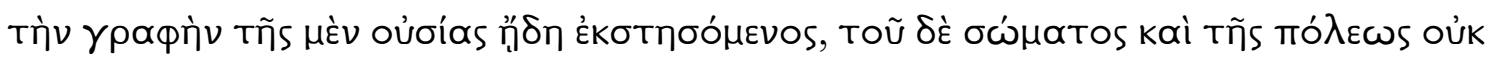

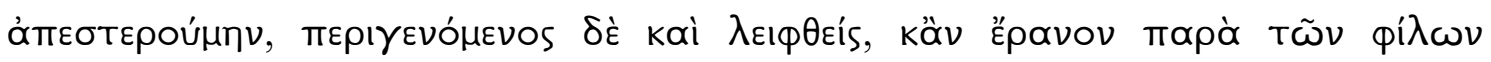

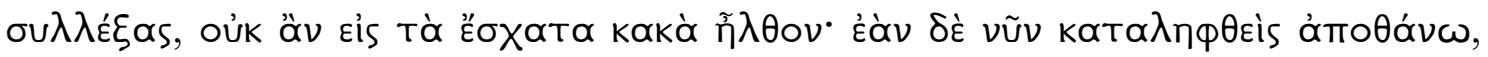

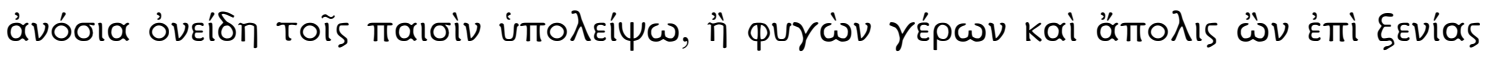

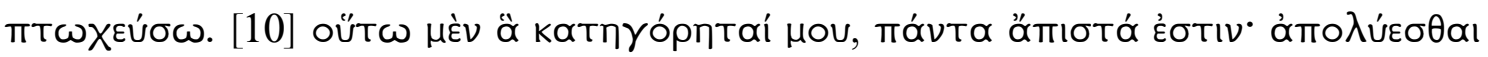

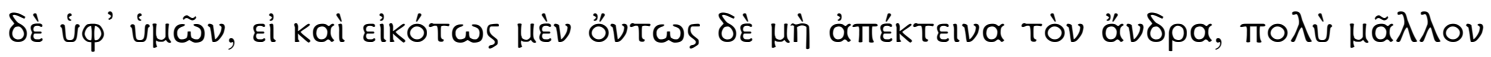

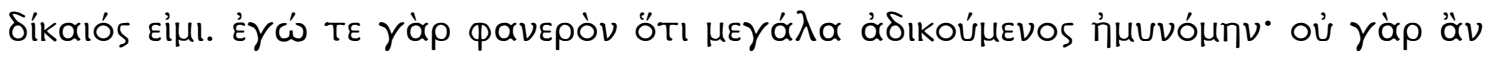

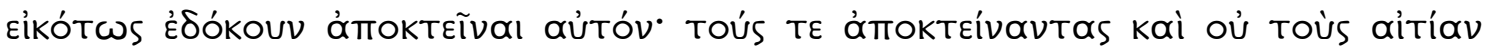

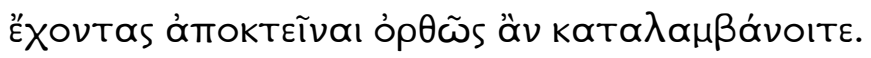

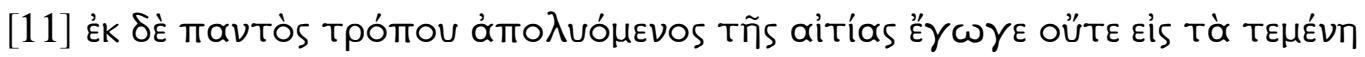

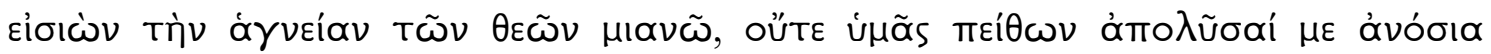




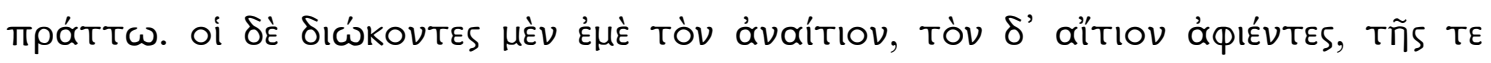

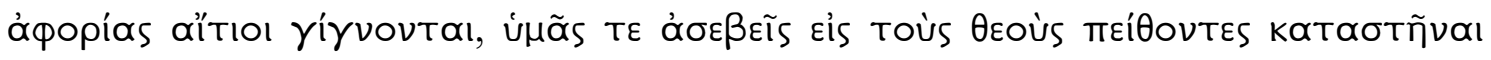

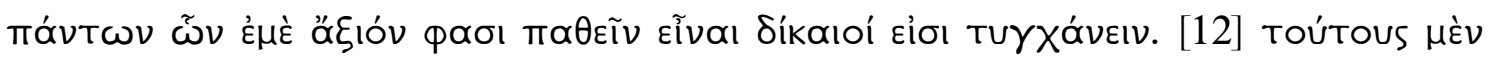

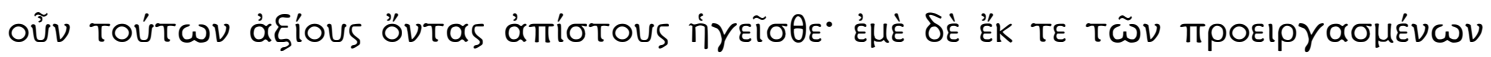

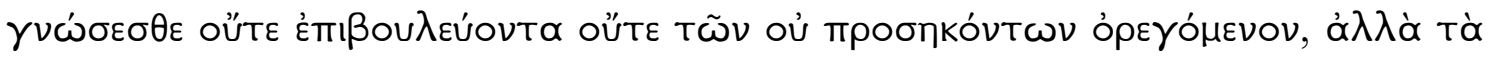

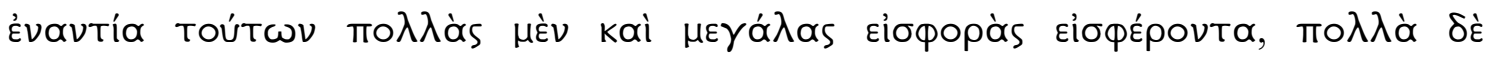

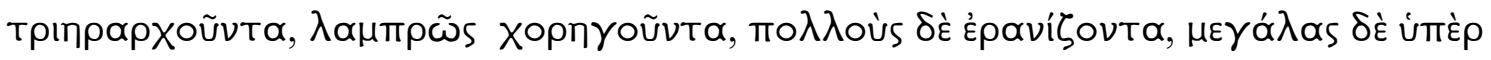

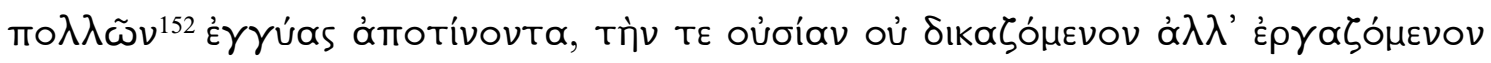

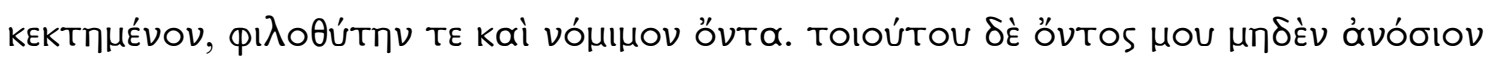

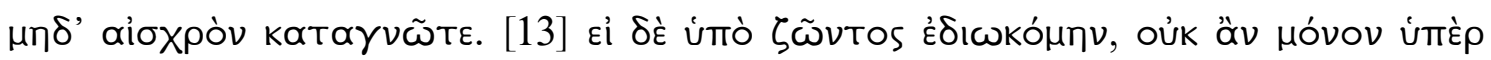

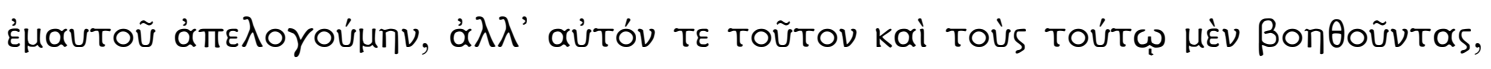

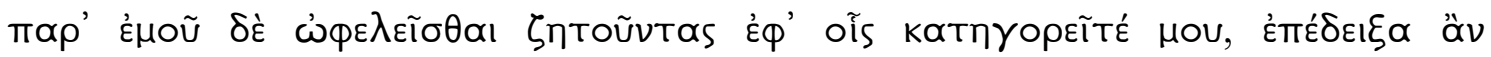

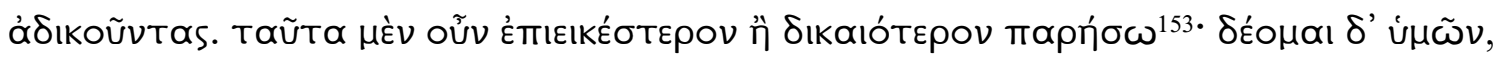

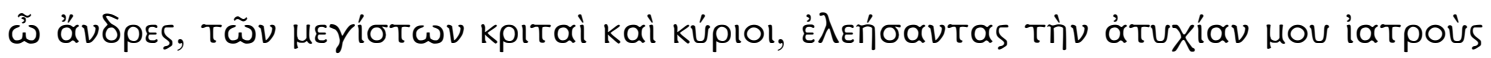

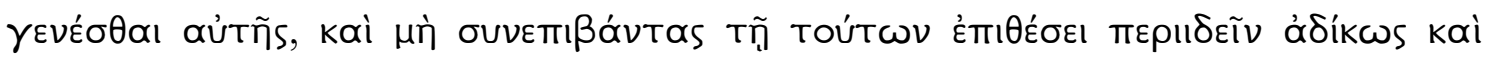

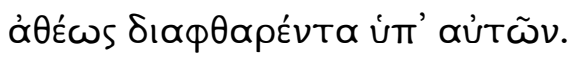

\section{[2.2]}

[1] Não julgo que erro ao me considerar o mais desafortunado de todos os homens. Pois os demais desafortunados, sempre que sofrem com o mau tempo, encontram o repouso com a volta da bonança ${ }^{154}$; e sempre que adoecem, tornam-se saudáveis assim que recobram a saúde; também se alguma outra desgraça os atinge, as coisas adversas que se seguem são benéficas ${ }^{155}$. [2] Para mim, enquanto viveu, aquele

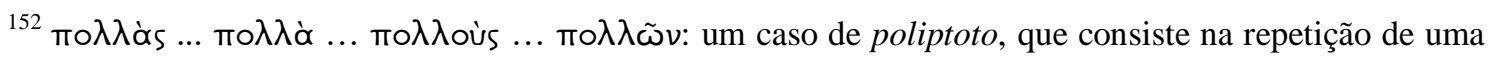
palavra, no caso moגús, em diferentes casos

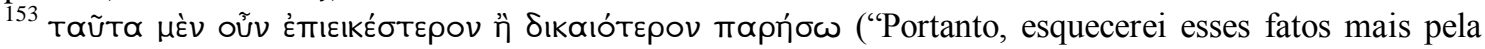
conveniência que pela justiça"): figura retórica chamada paráleipsis. No trecho mencionado, haveria uma

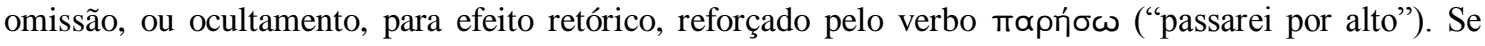
atentarmos para a oração que antecede o trecho em questão, notaremos que aquele que fala não quer dizer exatamente aquilo que já está dizendo. Essa figura permite ao falante mais insinuar do que propriamente dizer.

${ }^{154}$ eủóías: "bom tempo", "calmaria”, um termo jônico. Decleva-Caizzi (ANTIPHONTIS, 1969, p. 180) e José Redondo Sanchéz (ANTIFONTE, 1991, p. 44) sugerem que talvez haja na imagem da passagem do

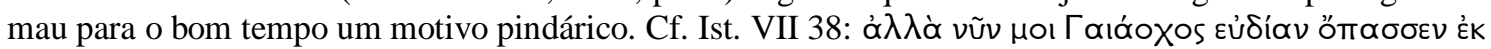
$\chi \varepsilon \mu \tilde{\omega}$ vos. "Mas agora Posseidon me enviou o bom tempo depois da tempestade".

${ }_{155}$ Gernet destaca nesse primeiro parágrafo um "desenvolvimento" literário, ainda que conciso, que está presente também em 4.1.1 (ANTIPHON, 1954, p. 56). Decleva-Caizzi também atenta para o tom dramático e o estilo literário do início desse discurso (ANTIPHONTIS, 1969, p. 180). O topos da captatio
} 
homem foi o destruidor de meu lar; estando ele morto, mesmo se eu for absolvido, tem me causado bastante dor e preocupação. Pois chego a tal ponto de desventura que, para

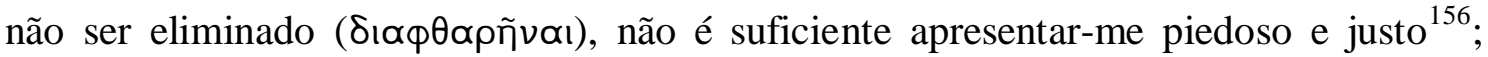
mas mesmo que eu seja condenado à morte, não encontrando o assassino - que os vingadores da vítima são incapazes de encontrar -, serei condenado impiamente ao ser, eu mesmo, o suspeito ${ }^{157}$ do homicídio. [3] Eles também afirmam que é muito difícil que eu, que sou hábil em falar ${ }^{158}$, seja condenado, mas que está claro que eu, que sou tolo por causa das próprias coisas que realizei, pratiquei a ação ${ }^{159}$. Pois se agora, em razão da

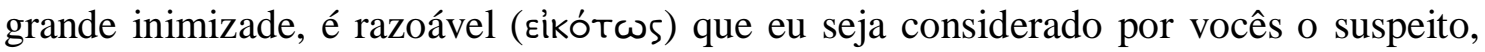

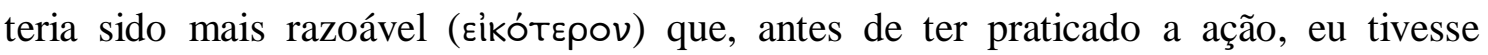
previsto a suspeita que agora recai sobre mim; e se soubesse que algum outro tramava contra ele, teria sido mais razoável ter impedido mais do que, praticando eu mesmo a ação, ter me exposto intencionalmente à suspeita tão evidente. Pois se, a partir da própria a ação, ficasse evidente que eu matei, estaria completamente perdido; e, se eu passasse despercebido, saberia claramente que essa suspeita recairia sobre mim. [4] Miserável, portanto, é a minha condição, sendo forçado não só a fazer minha defesa, mas também a tornar claro os assassinos. Entretanto, também isso devo fazer, pois nada parece ser mais amargo do que a necessidade. Mas não posso encontrar a prova por outro meio senão por aquele ${ }^{160}$ usado pelo acusador que, absolvendo os demais, afirma que a circunstância da própria morte indica que sou eu o assassino. Pois, se a aparente inocência dos demais faz o crime recair sobre mim, sendo eles os suspeitos, eu, com justiça, pareceria inocente e puro ${ }^{161}$.

benevolentiae é bem evidente nesse proêmio. Trata-se de um recurso retórico em que o litigante apela para a boa vontade dos juízes. Ele também estará presente em 3.2.1-2.

${ }^{156}$ öбıov kaì Síkaıov ("piedoso e justo"): esse par ocorre exatamente oito vezes nas Tetralogias (2.2.2, 2.4.12, 3.2.2, 3.2.12, 3.3.11, 3.4.10, 4.2.2, 4.2.9). Decleva-Caizzi entende que essa estreita conexão entre as esferas divina e humana é o tema central da obra (ANTIPHONTIS, 1969, p. 182).

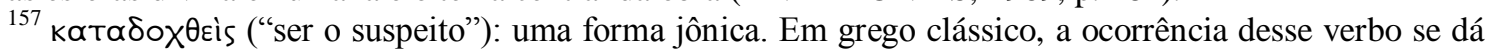
apenas nas Tetralogias, em 2.2.2 e 2.3.7, e em Heródoto.

${ }^{158}$ Selvóv:"habilidoso", "eloquente".

${ }^{159}$ A defesa, a partir da conclusão da acusação, enfatiza a contradição em ser ao mesmo tempo astuto e tolo. Cf. Górgias, Defesa de Palamedes, 25.

${ }^{160}$ Isto é, a defesa vai usar o mesmo argumento que a acusação, ou seja, vai usar o Eikós.

${ }^{161}$ Para Gagarin, nas Tetralogias, kaӨ $\propto$ pós pode tanto significar "inocente", comum entre os oradores, como "livre de contaminação", seu sentido literal (ANTIPHON, 1997, p. 132). Em sua tradução, o comentador opta por traduzir por "inocente". Decleva-Caizzi, traduz por "puro". Optamos por uma construção composta "inocente e puro", porque a passagem parece fazer referência tanto ao fato de ser inocente do ponto de vista legal quanto ao de ser puro do ponto de vista religioso. 
[5] Não é pouco plausível (åmeıkós) ${ }^{162}$, como eles dizem, mas plausível (Eỉkós) que, por causa de suas roupas, a vítima tenha sido eliminada ao perambular em uma

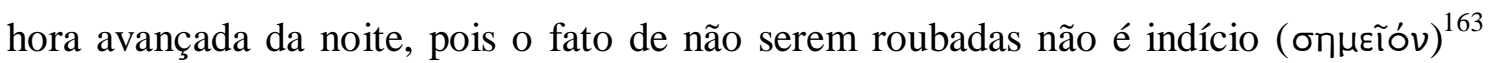
algum. Se não se apressaram em roubar as roupas, mas escaparam por temer a aproximação de alguém, foram prudentes e não tolos, valorando antes a salvação do que o ganho. [6] E se também ela não foi eliminada por causa de suas roupas, mas porque viu outros praticando algum outro mal? Quem sabe foi morta por eles para não se tornar o denunciador desse crime? ${ }^{164}$ E os que o odiavam não muito menos do que eu - e eram muitos -, como não haveria de ser mais razoável (Eíkós) que eles tivessem matado esse homem e não eu ${ }^{165}$ Pois, para aqueles, era evidente que a suspeita recairia sobre mim, enquanto que eu sabia claramente que seria responsabilizado no lugar deles. [7] Quanto ao testemunho do escravo, como ele pode ser digno de confiança? Pois não seria plausível (Eíkós) que ele, aterrorizado pelo perigo, reconhecesse os assassinos, mas seria sim plausível que ele fosse induzido pelos seus senhores ${ }^{166}$ àquilo que eles o fizessem reconhecer. Desconfiando também dos testemunhos dos demais escravos - caso

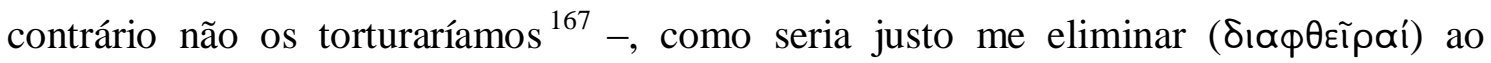
confiar em um tal testemunho ${ }^{168}$

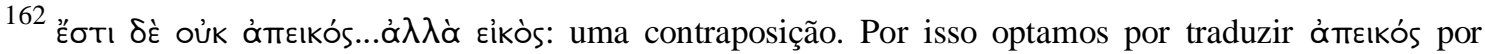
"plausível".

163 on $\mu$ ĩóv: "indício".

${ }^{164}$ Uma pergunta retórica.

${ }^{165}$ Outra pergunta retórica.

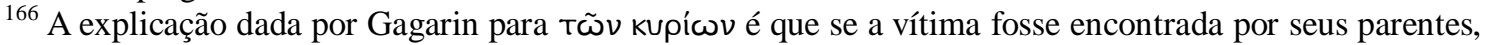
o seu escravo teria como mestres, ou senhores, esses parentes (ANTIPHON, 1997, p. 132).

${ }^{167}$ A partir de evidências encontradas na oratória forense, C. Carey, no artigo A Note on Torture in Athenian Homicides Cases (1988), destaca que o uso da tortura ou do interrogatório mediante tortura (ßóoovos) era reservado aos escravos em quase todas as ações legais em Atenas e que seus testemunhos eram admissíveis no tribunal apenas se extraído sob tortura (Antifonte 1.6-13; 2.2 .7 e 2.4.8; 6.23-7). Haveria, contudo, evidências de que, em alguns casos, como naqueles em que a segurança do Estado estaivesse em risco, não-cidadãos livres poderiam também ser submetidos ao procedimento (Antifonte 5.46-9; Lísias 4.12-7 e talvez Lísias 3.33). Gagarin, no estudo The Torture of Slave in Athenian Law (1996), reforça a informação de Carey de que os atenienses permitiam a tortura de escravos e talvez de não-cidadãos livres, mas não de cidadãos, e comenta que havia um tipo de tortura judicial única em Atenas, que ele chama de "evidentiary torture", que é a tortura de um escravo inocente (nunca uma testemunha livre) com o objetivo de verificar uma informação, que é o tipo retratado nessa Tetralogia I. Segundo Gagarin, muitas referências ao ßáoavoos nos oradores seriam precisamente sobre esse tipo de tortura. No mais, o ßá бavos será apresentado por Aristóteles como um dos cinco meios de persuasão independentes de arte, especialmente característicos da oratória forense (1375a23 - 1377b13).

${ }^{168}$ Uma pergunta retórica.
} 
[8] Se alguém que testemunha contra mim pensa que as coisas verossímeis (Tò Eíkóta $)^{169}$ são semelhantes à verdade, que, de modo similar ${ }^{170}$, considere que seria mais

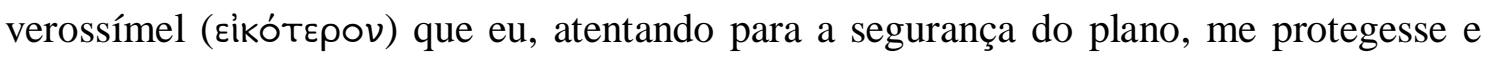
que não estivesse presente no momento do crime ao invés de me deixar reconhecer pelo escravo exatamente enquanto ele era abatido. [9] Que eu, ao menos que estivesse fora de mim, não pensava que esse ${ }^{171}$ risco era menos terrível do que o oriundo da acusação de roubo, mas muito mais grave, é o que mostrarei ${ }^{172}$. Pois eu sabia que, se fosse condenado pela acusação de roubo, seria despojado de meus bens, mas não seria privado de meu corpo e de minha cidade $^{173}$; e que, tendo salvo a vida e os direitos civis, mesmo se eu tivesse recolhido junto aos amigos um empréstimo em dinheiro ${ }^{174}$, não teria chegado aos males extremos ${ }^{175}$. Mas se agora eu vier a ser condenado e morto, deixarei aos meus filhos uma desonra por impiedade, ou se eu vier a ser exilado, mendigarei velho e apátrida em terra estrangeira ${ }^{176}$. [10] Assim, nenhuma das coisas de que ele me acusa é convincente. Ser absolvido por vocês, ainda que de modo plausível

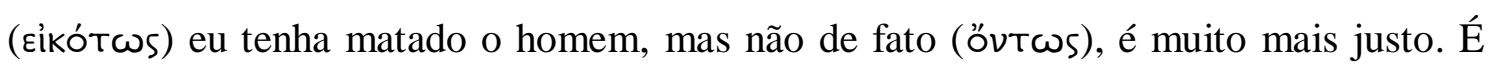
evidente, com efeito, que eu estaria me defendendo de uma grave injustiça ${ }^{177}$, do

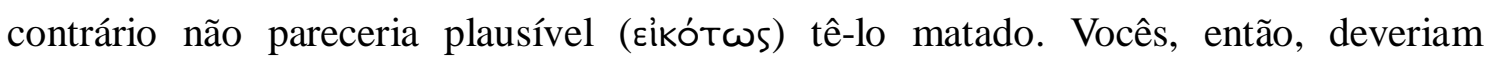
condenar corretamente os que matam e não os que são acusados de matar.

[11] Sendo absolvido da acusação de todas as maneiras, eu mesmo nem profano a santidade dos deuses ao adentrar em seus recintos sagrados, nem pratico alguma impiedade ao persuadir os senhores a me absolver. Os que acusam a mim, um inocente, deixando livre o culpado, tornam-se, estes sim, os responsáveis pela esterilidade da terra. Ao persuadirem os senhores a se apresentarem ímpios perante os deuses, é justo que tudo aquilo que dizem que sou merecedor de sofrer obtenham. [12] Considerem, portanto, indignos de confiança estes que são merecedores de tais coisas. Quanto a mim,

\footnotetext{
${ }^{169}$ Nessa passagem traduzimos Eikós por verossímil por haver uma clara contraposição entre as coisas verdadeiras e aquelas semelhantes à verdade.

${ }^{170}$ TaủTóv com sentido adverbial de "igualmente", "de modo similar".

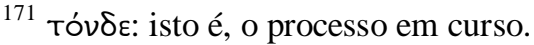

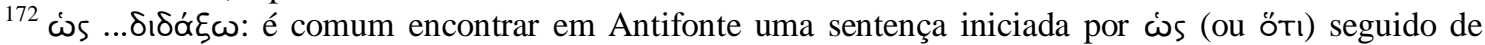
verbo principal.

${ }^{173}$ Isto é, executado ou exilado caso fosse condenado pelo homicídio.

174 हैpavos: um empréstimo sem juros recolhido junto a amigos em caso de multa elevada.

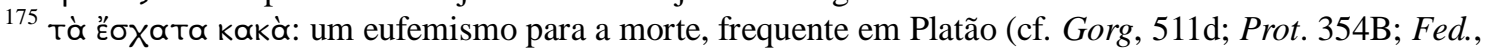
$83 \mathrm{c} ;$ Fedr., 247b)

${ }^{176}$ Havia a opção do exílio ao invés da pena de morte. O réu deveria optar pelo exílio antes de seu segundo discurso. É o que acontece, por exemplo, na Tetralogia III.

${ }^{177}$ Isto é, do processo de roubo.
} 
a partir das ações anteriormente realizadas ${ }^{178}$, compreenderão que nem planejei nem ambicionei coisas que a mim não convinham, mas, ao contrário, tenho fornecido muitas e substanciosas contribuições; desempenhado muitas vezes a função de trierarca; exercido brilhantemente a coregia ${ }^{179}$; ajudado muitos com empréstimos ${ }^{180}$; e garantido em favor de muitos grandes cauções ${ }^{181}$. Além do mais, não tenho adquirido meus bens em litígios ${ }^{182}$, mas trabalhando; e tenho sido respeitoso com os sacrifícios e as leis ${ }^{183}$. Sendo tal como sou, não me acusem de nenhuma ação ímpia ou torpe. [13] Se eu fosse acusado por alguém ainda vivo, não apenas faria um discurso em minha própria defesa, como também demonstraria que a própria vítima e aqueles que dizem que a socorreram ${ }^{184}$ estariam agindo injustamente e buscando se beneficiar às minhas custas motivo pelo qual vocês estão me acusando. Portanto, deixarei de lado esses fatos mais pela conveniência que pela justiça; e peço a vocês, ó homens, juízes e senhores das causas mais grandiosas, que após se apiedarem de meu infortúnio, encontrem um remédio para ele e que, não se unindo aos ataques de meus oponentes, não permitam que eu seja mo rto por eles de forma injusta e ímpia.

\section{$2.3^{185}$}

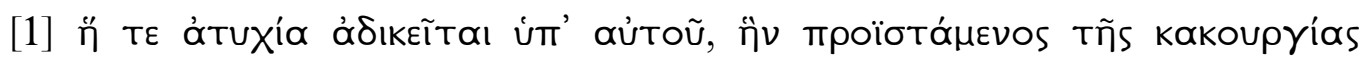

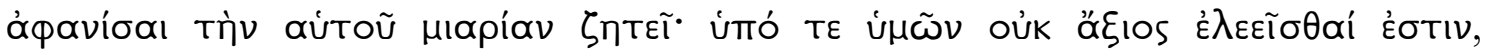

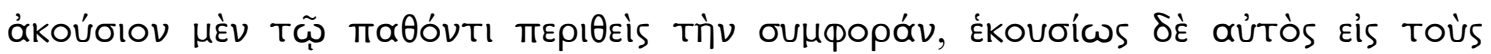

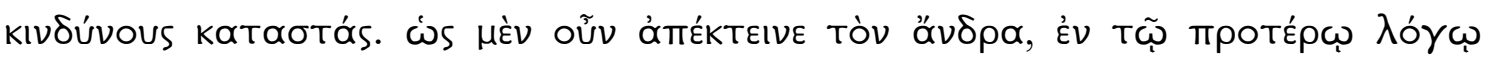

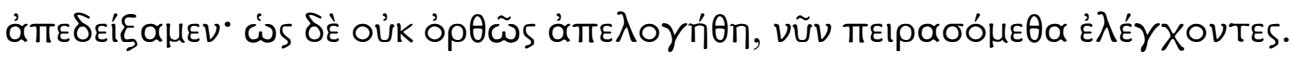

\footnotetext{
${ }^{178} \mathrm{O}$ réu se refere aos serviços desempenhados na cidade e que seriam frequentemente mencionados em defesas no tribunal.

${ }^{179}$ As três mais importantes liturgias ou serviços públicos que, de acordo com Maidment (ANTIPHON, 1953, p. 66-7), um membro rico da comunidade era obrigado a empreender de quando em quando: a Eỉoфopó, ou contribuição, solicitada em casos extraordinários; a função de trierarca, que comandava uma trirreme (barco de guerra) durante um ano; e a coregia, em que o corego tinha que pagar e treinar um coro para festivais dramáticos ou corais comuns em Atenas.

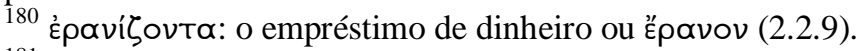

${ }^{181}$ Em processos judiciais, era a garantia de que o acusado responderia por suas acusações.

${ }^{182} \mathrm{O}$ que poderia lhe render a acusação de sicofanta.

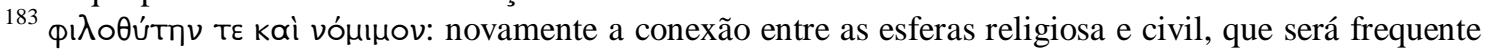
nas Tetralogias. Os termos ávóoiov ("ímpio") e aíoxpóv ("torpe", "desonroso"), que se seguem, e

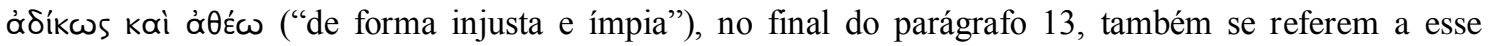
paralelismo entre o divino e o humano.

${ }^{184}$ ßonӨoũvtas: uma expressão sarcástica.

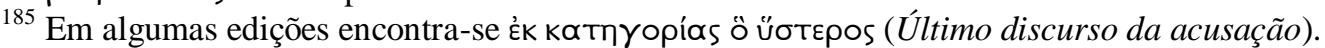




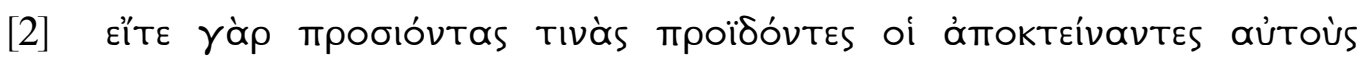

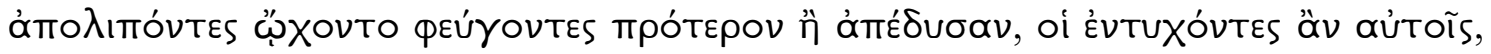

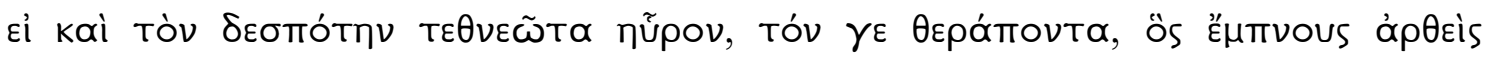

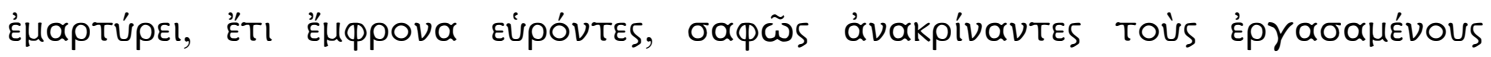

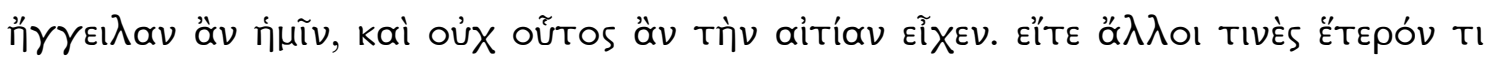

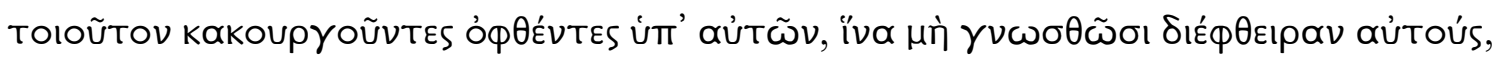

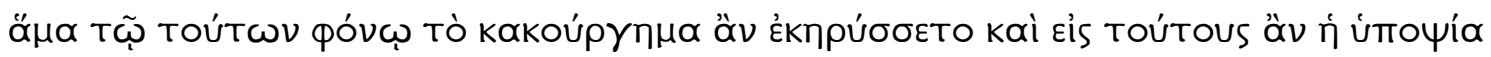

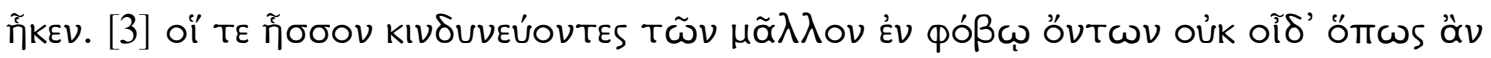

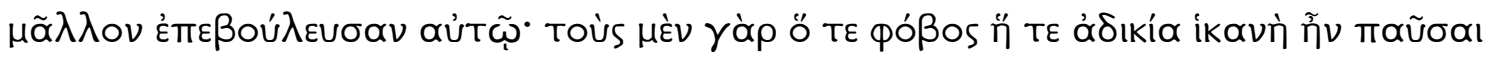

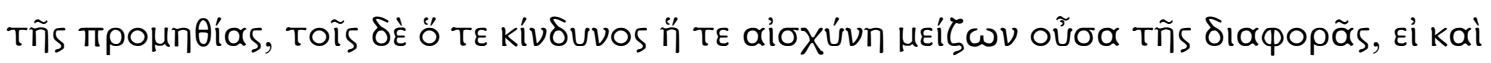

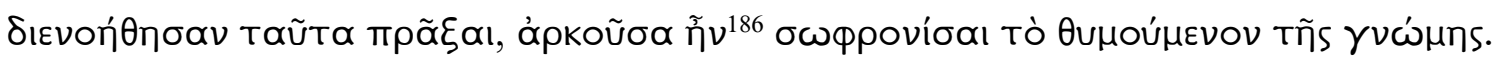

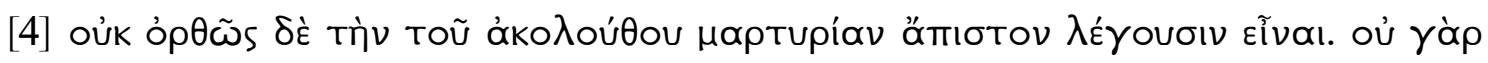

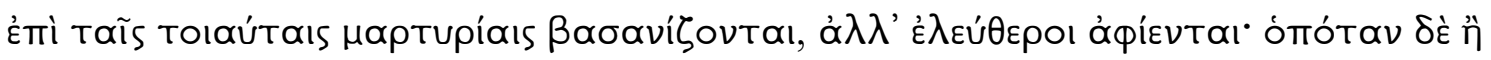

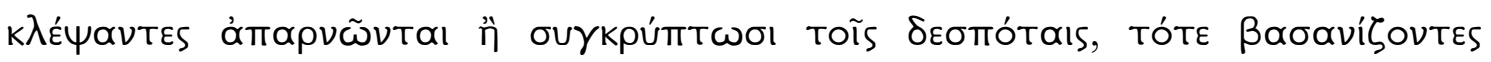

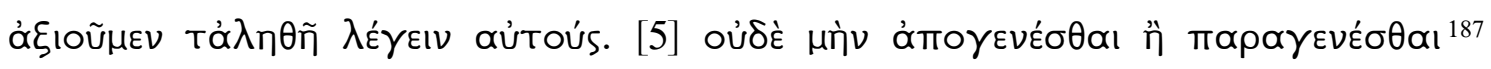

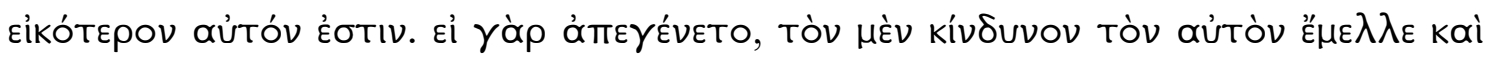

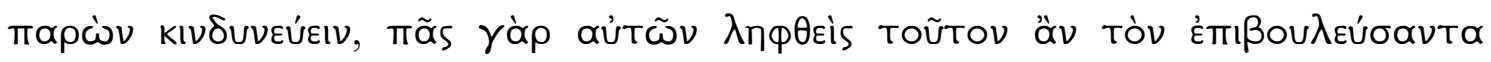

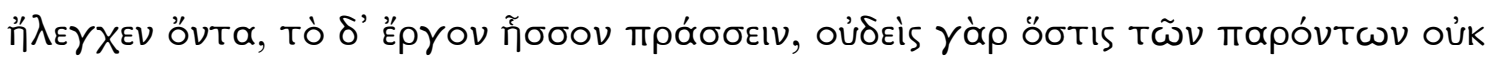

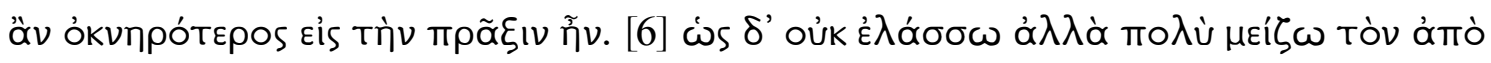

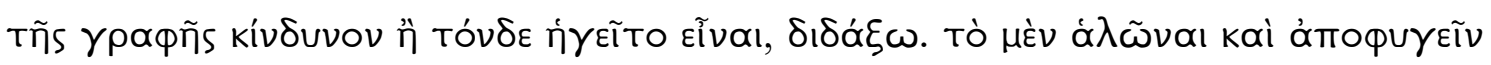

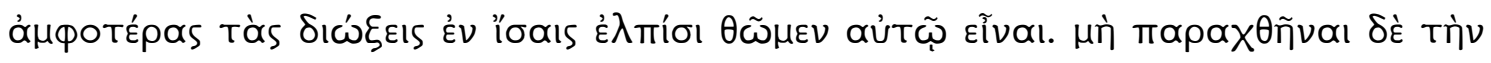

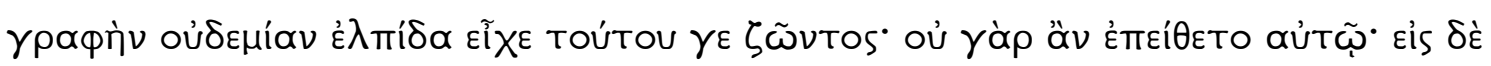

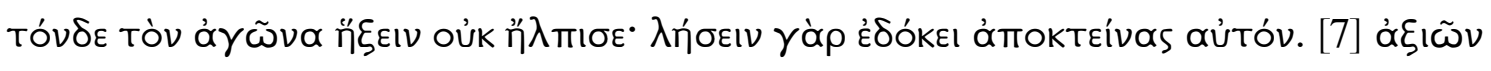

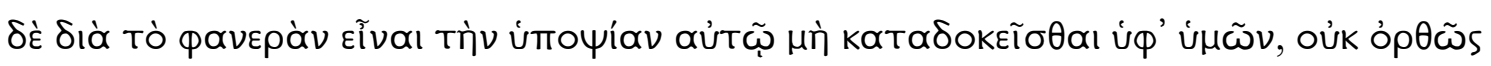

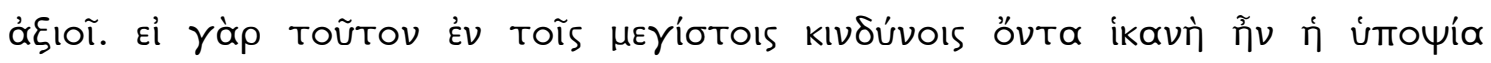

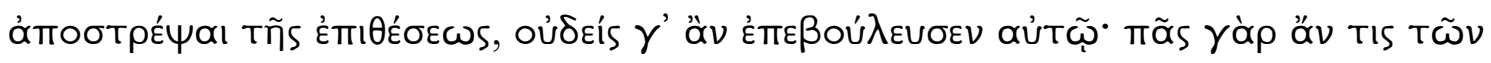

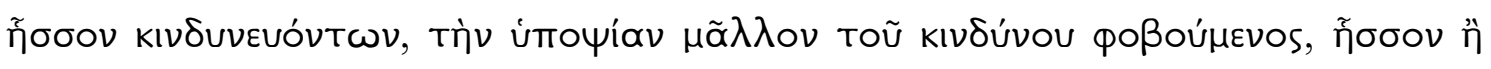

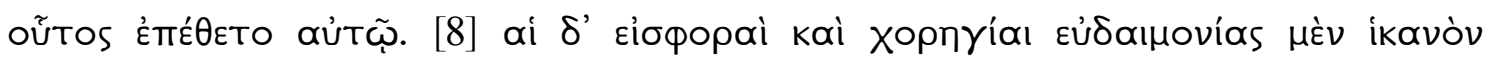

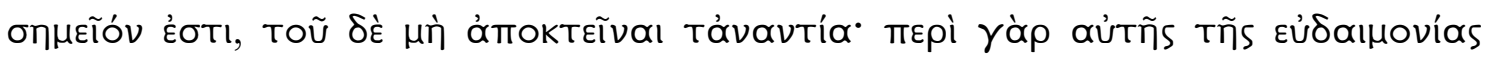

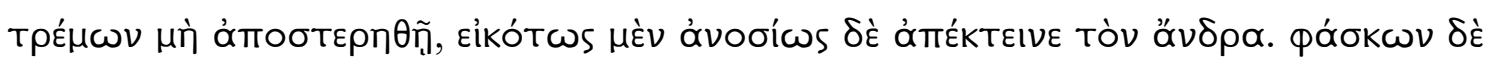

\footnotetext{
${ }^{186}$ Construção perifrástica em ả ó

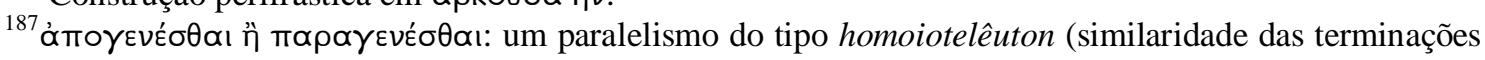
dos dois infinitivos).
} 


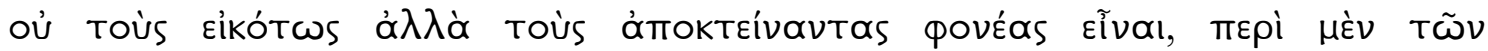

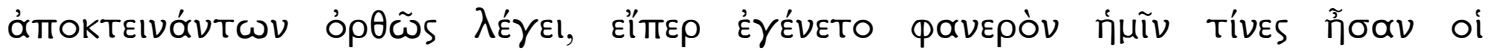

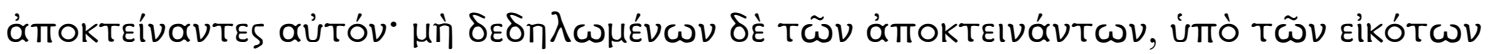

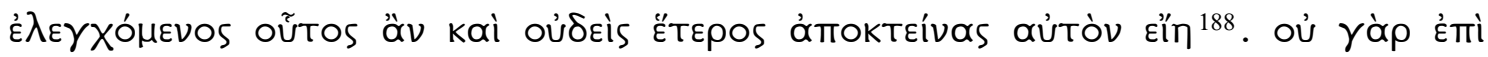

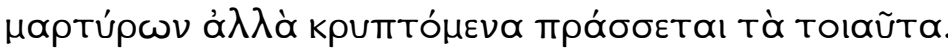

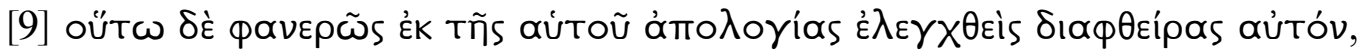

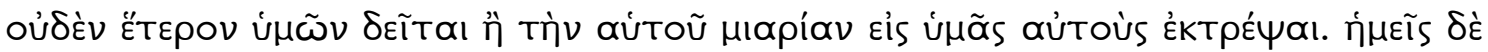

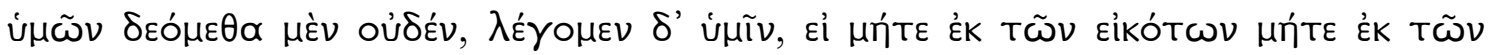

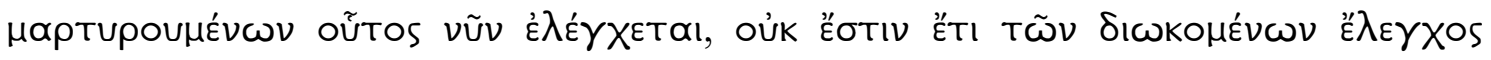

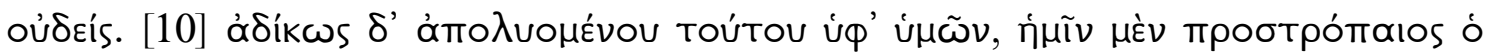

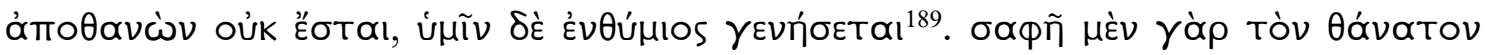

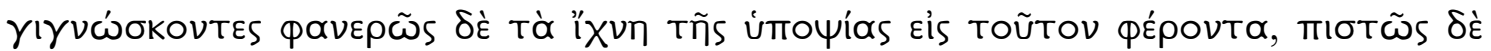

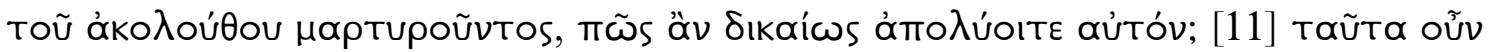

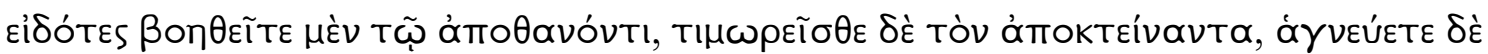

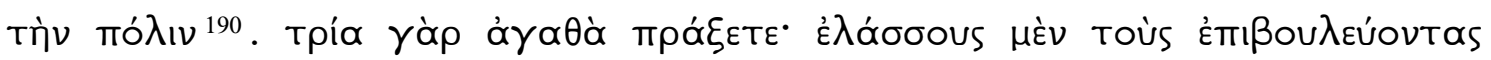

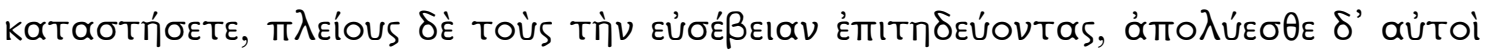

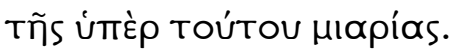

\section{3}

[1] O infortúnio (ótuxía) ${ }^{191}$ é ultrajado por este homem, com o qual, encobrindo sua má ação, busca ocultar a própria impureza ${ }^{192}$. Ele não é digno da piedade dos senhores, tanto porque impôs à vítima uma desgraça não desejada, quanto porque ele mesmo se expôs aos riscos de forma intencional. Que ele, portanto, matou o homem,

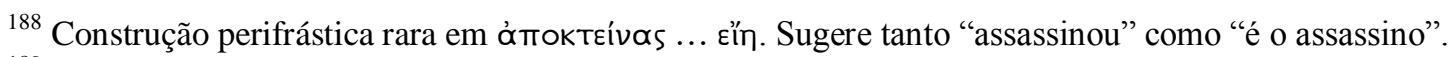

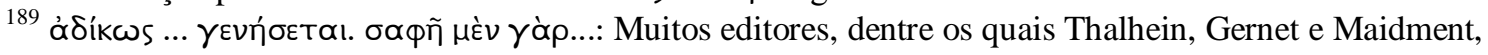
invertem as posições das duas orações. Seguimos a escolha de Gagarin.

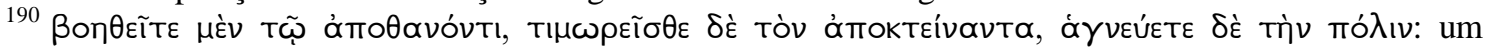
paralelismo do tipo parísosis (orações com o mesmo tamanho), com três imperativos no começo de cada oração, embora havendo variação na unidade entre elas.

${ }^{191}$ Logo no proêmio, a acusação busca rebater o discurso anterior da defesa, que enfatizou sua situação desafortunada. E isso ocorre com a personificação de um nome abstrato, no caso átuxía.

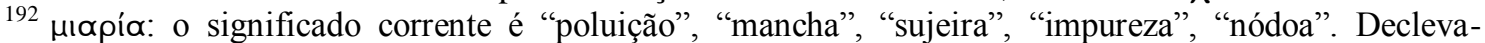
Caizzi e Morrison traduzem, respectivamente, por "culpabilidade do homicídio" e "culpa pelo crime de sangue". De acordo com Gagarin, a ocorrência mais antiga desse equivalente raro de $\mu$ ía $\sigma \mu \alpha$ apareceria nas Tetralogias (ANTIPHON, 1997, p. 136) Cf. 2.3.9, 3.3.12.
} 
demonstrei no primeiro discurso; que ele não fez corretamente ${ }^{193}$ sua defesa, nos esforçaremos agora para $\operatorname{provar}^{194}$.

[2] Se os assassinos, vendo que algumas pessoas se aproximavam, abandonaram o senhor e o escravo e partiram em fuga antes de roubar suas roupas, aqueles que por ventura tivessem se deparado com os dois, ainda que tendo encontrado o senhor morto, teriam achado o escravo consciente, ainda respirando e podendo testemunhar; e se o tivessem interrogado exaustivamente, teriam anunciado para nós os realizadores da ação e este aí não teria a culpa. Se outros, por terem sido vistos pelas vítimas cometendo um delito tal como esse contra algum outro, mataram a fim de não serem reconhecidos, essa má ação teria sido reportada junto com o homicídio delas e a suspeita teria recaído sobre esses malfeitores. [3] Quanto aos que corriam menos riscos, não sei como teriam tramado contra ele mais do que os que tinham mais a temer. Pois, enquanto nestes, o medo e a injustiça sofrida ${ }^{195}$ seriam suficientes para fazer cessar a precaução, naqueles, o risco e a desonra ${ }^{196}$, sendo maiores do que a desavença, seriam suficientes para moderar o ânimo irado, ainda que tivessem em mente realizar essas ações. [4] E não dizem de modo correto que o testemunho do escravo não é confiável, pois em situações de tais testemunhos, eles não são submetidos à tortura, mas livres são deixados ${ }^{197}$; apenas quando negam ter praticado um roubo ou ajudam seus senhores a acobertar algum crime, então consideramos que eles dizem a verdade quando torturados. [5] Tampouco é mais plausível (દíkótepov) que o acusado estivesse ausente do que presente. Se estivesse ausente teria corrido o mesmo risco que estando presente - pois qualquer um daqueles que tivesse sido capturado teria confirmado que o acusado arquitetou o crime -, ele apenas teria realizado a ação menos efetivamente, pois qualquer um dos presentes, quem quer que fosse, não estaria tão entusiasmado para a ação. [6] Que ele pensava que o risco da acusação de roubo não era menor do que a desse julgamento, mas muito maior, é o que eu mostrarei ${ }^{198}$. Suponhamos que, para o réu, havia a mesma expectativa de ser condenado ou de ser absolvido em ambos os

\footnotetext{
193 òp $\theta \tilde{\omega}$ s: com correção, isto é, com validade.

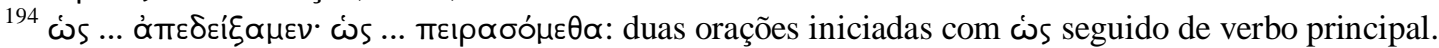

${ }^{195}$ Isto é, o medo da acusação de roubo ( $\left.\gamma \rho \alpha \varphi n ́\right)$ e o suposto erro do homem morto contra o réu, que despertou neste um senso de vingança. Gagarin entende que á $\delta$ ı́ía não se refere a um crime que a vítima teria cometido, mas uma injustiça cometida por ela contra o réu (ANTIPHON, 1997, pp. 133-37).

${ }^{196}$ Isto é, o perigo de ser preso e suas consequências e a desonra resultante do crime de assassinato.

${ }^{197}$ Decleva-Caizzi e Gagarin explicam que havia a possibilidade de um escravo ser interrogado sem ser submetido à tortura, mas livre. (ANTIPHONTIS, 1969, pp. 196-97; ANTIPHON, 1997, p. 137). Cf. Antifonte, 5.34.

${ }^{198}$ Sentença iniciada por $\omega \dot{s}$ seguido de verbo principal $(\delta เ \delta \alpha ́ \xi \omega)$.
} 
processos. Ele não tinha nenhuma esperança de que a acusação de roubo fosse descartada enquanto a vítima vivesse, pois não teria chegado a um acordo com ela fora do tribunal; e não esperava chegar até esta disputa judiciária, pois pensava de fato que mataria o homem e não seria descoberto. [7] Ao avaliar que, porque a suspeita contra ele era evidente, não seria considerado por vocês o suspeito, não avaliou corretamente. Pois se a suspeita tivesse sido suficiente para deter o ataque desse homem, que estava envolto nos maiores riscos, ninguém teria tramado contra a vítima, pois qualquer um dos que corriam menos riscos, temendo a suspeita mais do que o risco, teria menos motivo para atacá-la que o acusado. [8] As contribuições em dinheiro e as coregias são

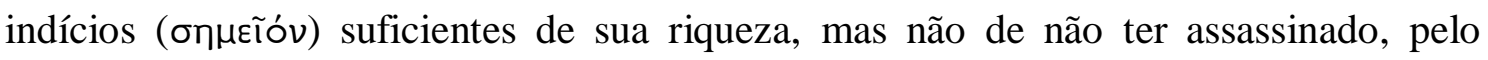

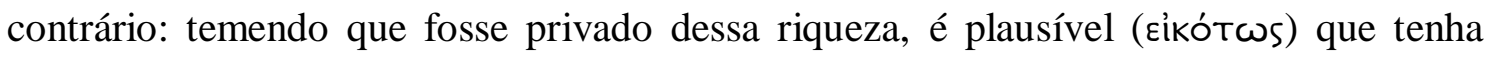
matado impiamente o homem. E quando o réu afirma que os assassinos são os que de

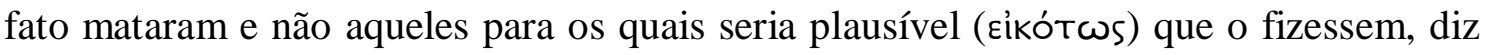
corretamente a respeito dos assassinos, se tivesse ficado claro para nós quais eram os assassinos. Mas se estes ainda não foram revelados, então o acusado, e nenhum outro,

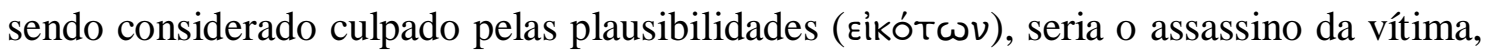
pois tais coisas não são feitas na presença de testemunhas, mas às escondidas.

[9] Assim, uma vez que está claramente provado, pelo próprio discurso de defesa do réu, que ele matou o homem, nenhuma outra coisa ele pede a vocês senão que transfiram a vocês mesmos a sua impureza ${ }^{199}$. Nós, por outro lado, não lhes pedimos nada, mas dizemos a vocês que, se agora o réu não é considerado culpado nem pelas

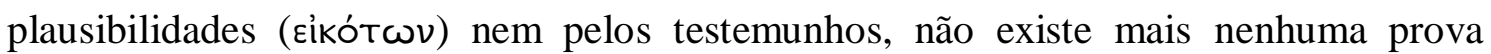
contra os acusados. [10] Mas se esse homem for absolvido injustamente por vocês, o espírito vingativo do morto (тробтрóтঞ๙ıৎ) não se voltará contra nós, mas será um

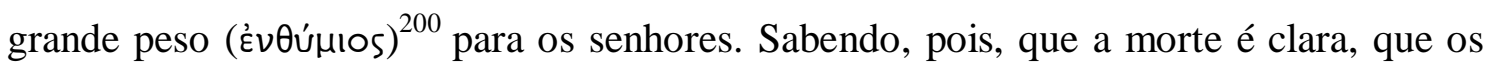
rastros da suspeita ${ }^{201}$ claramente conduzem ao réu e que o testemunho do escravo é confiável, como então, com justiça, poderiam absolvê-lo ${ }^{202}$ [11] Portanto, depois de

\footnotetext{
${ }^{199}$ Decleva-Caizzi nota que $\mu ı \alpha$ pía v surge como algo material, que é transmitido fisicamente de uma pessoa para outra. (ANTIPHONTIS, 1969, pp. 199-200).

${ }^{200}$ тробтро́таıо: о "еspírito de vingança do morto"; a vítima não vingada que retorna para se vingar.

غ̇vӨúpıos: "remorso", "peso que atormenta". Enquanto que, para Gagarin, trata-se do "peso sobre a consciência" daquele que não vingou uma vítima de crime de sangue (ANTIPHON, 1997, p. 139), para Decleva-Caizzi, as duas palavras poéticas são sinônimas (ANTIPHONTIS, 1969, p. 200).

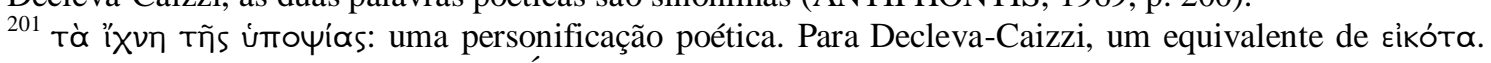
(ANTIPHONTIS, 1969, p. 200) (Cf. Ésquilo, Prom. v.845).

${ }^{202}$ Uma pergunta retórica.
} 
saberem isso tudo, socorram o morto, castiguem o assassino e purifiquem a cidade. Pois praticarão três boas ações: diminuirão o número dos que tramam, aumentarão os que praticam a piedade, e vocês mesmos ficarão livres das impurezas que emanam do acusado.

\section{$2.4^{203}$}

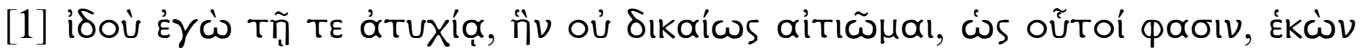

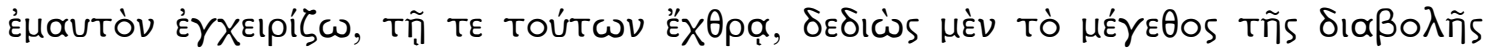

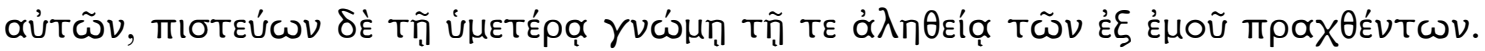

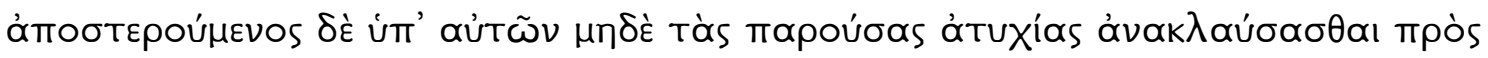

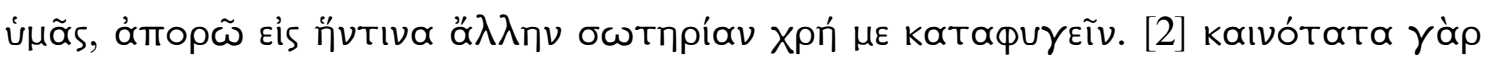

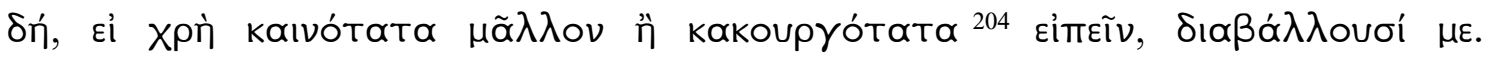

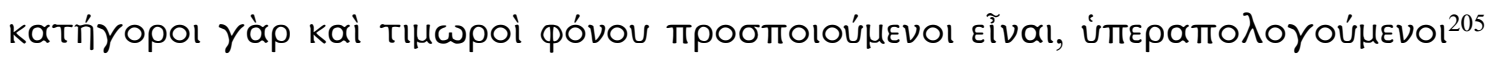

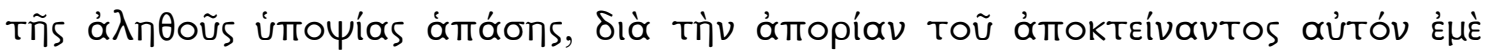

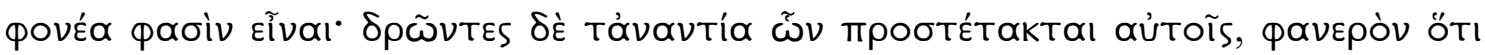

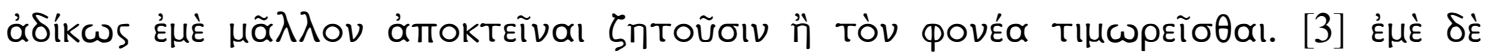

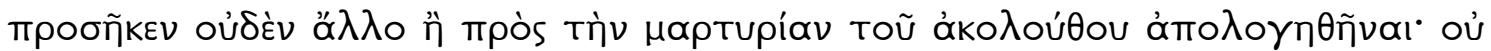

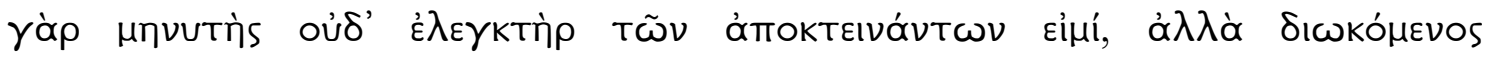

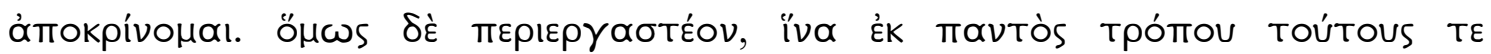

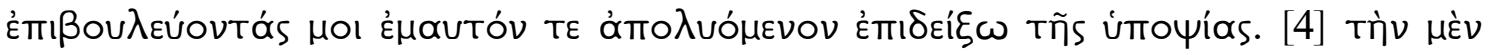

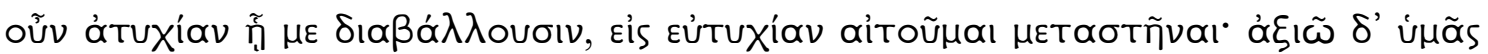

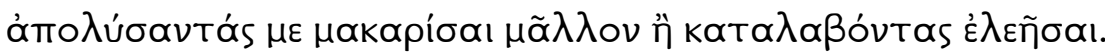

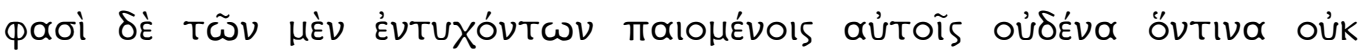

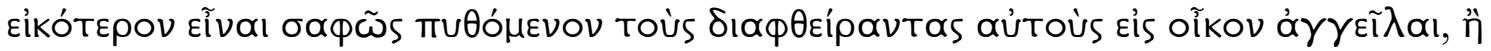

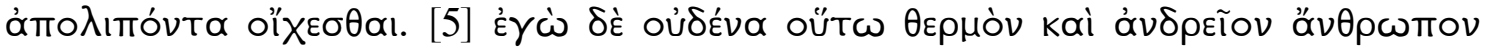

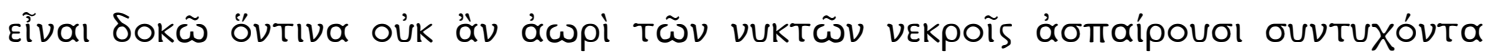

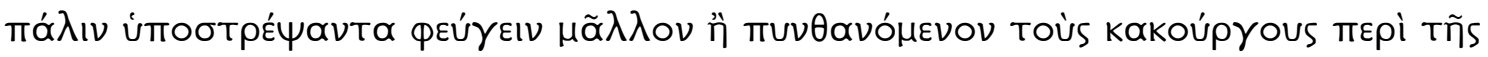

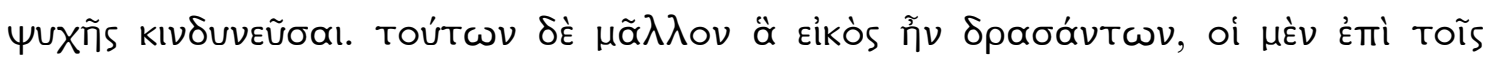

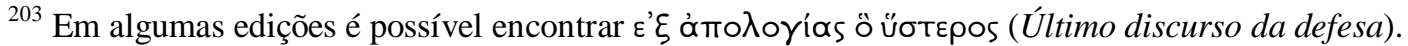

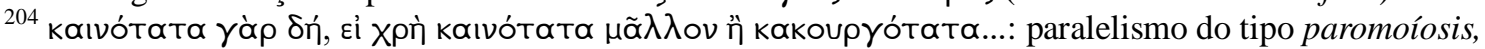
caracterizado pela similaridade dos sons de duas orações .

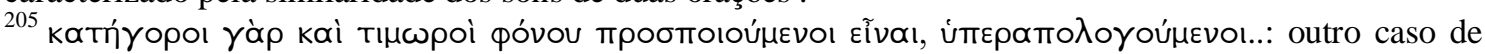
paromoíosis.
} 


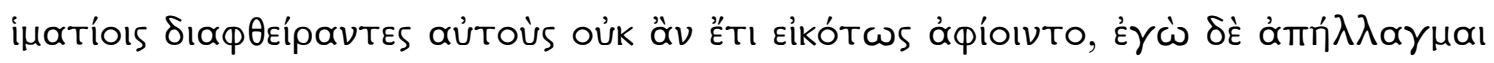

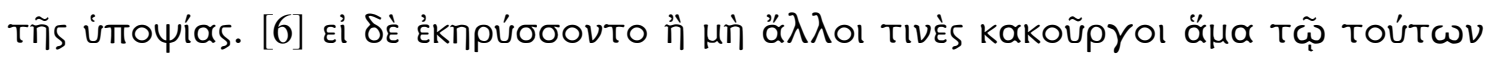

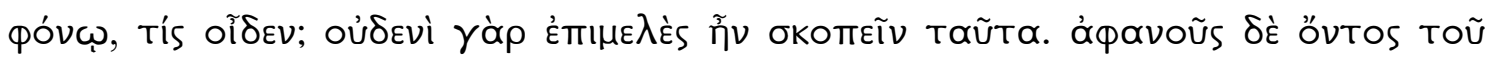

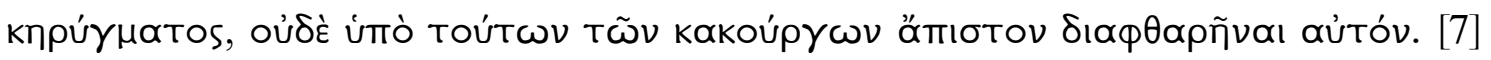

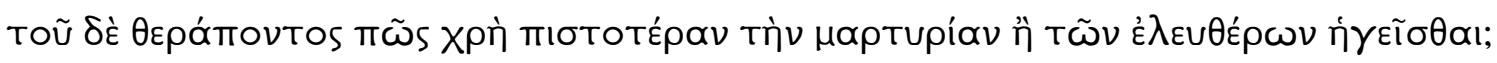

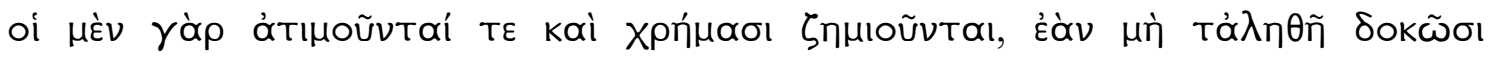

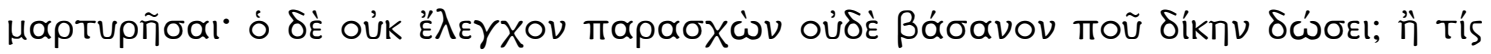

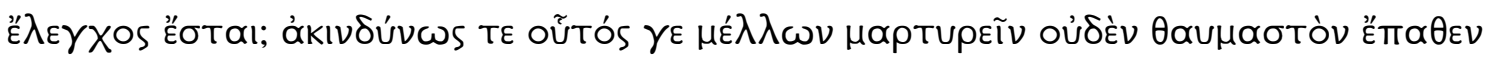

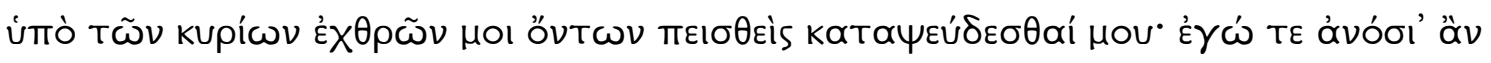

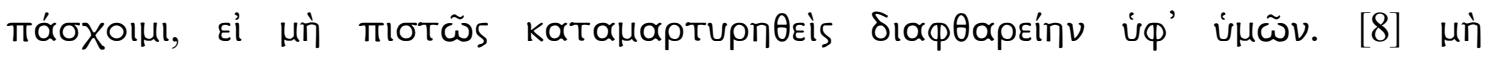

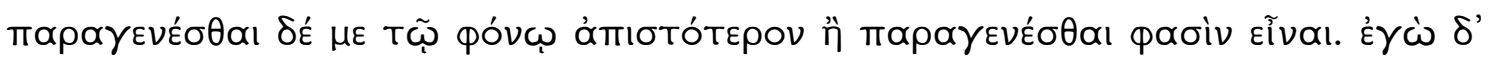

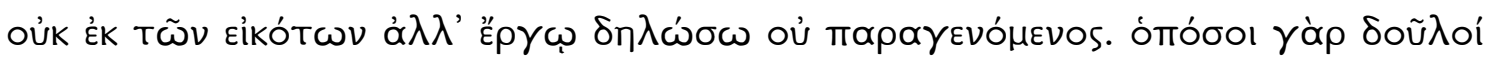

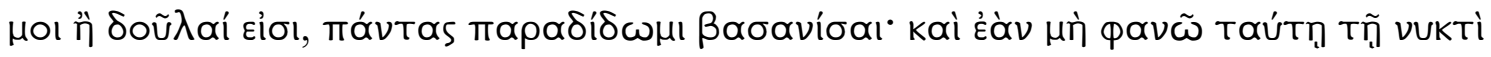

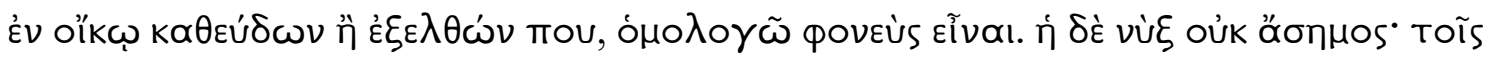

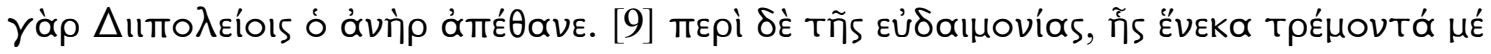

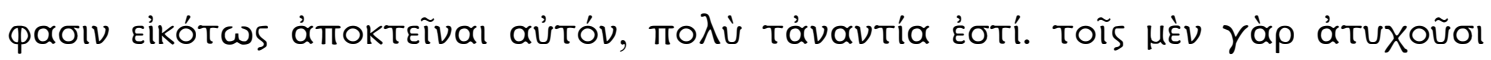

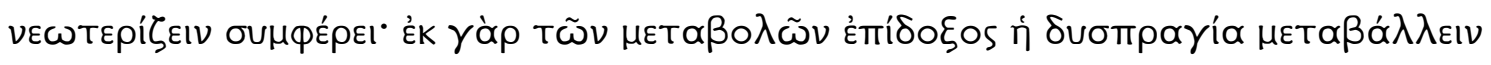

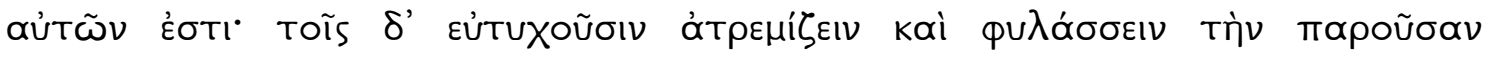

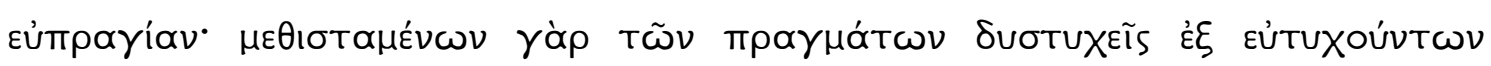

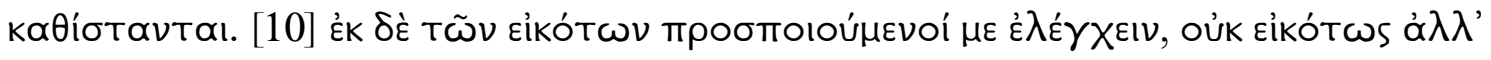

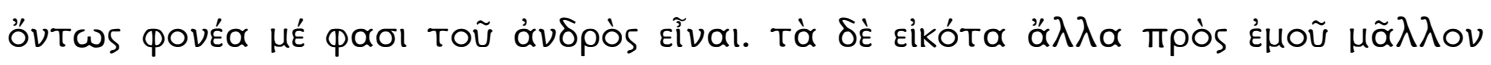

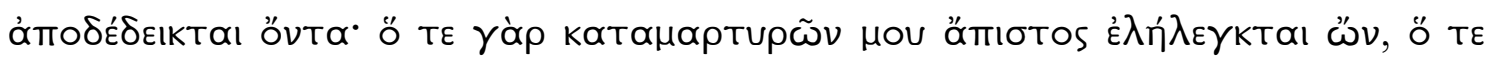

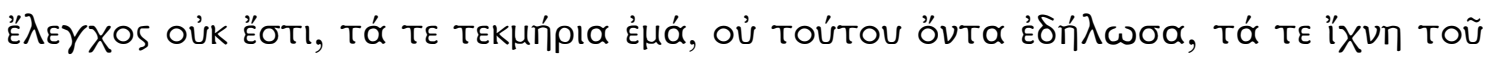

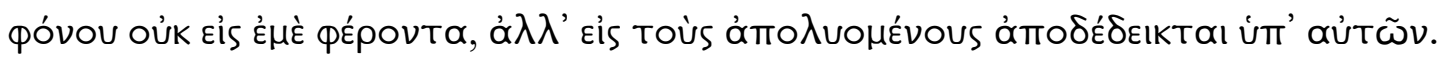

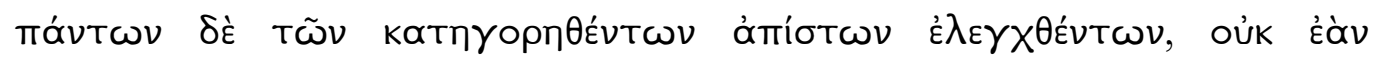

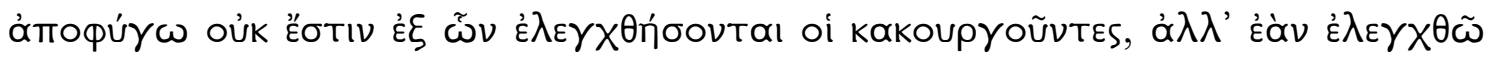

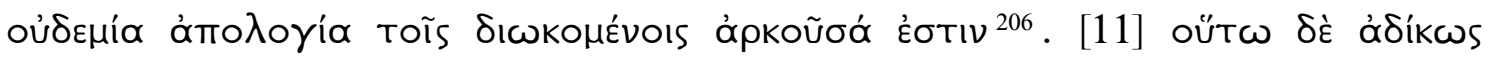

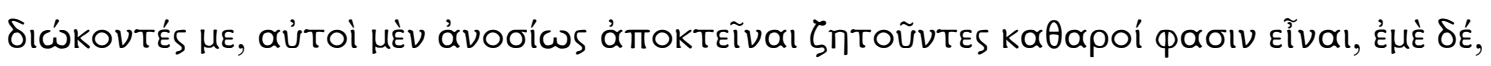

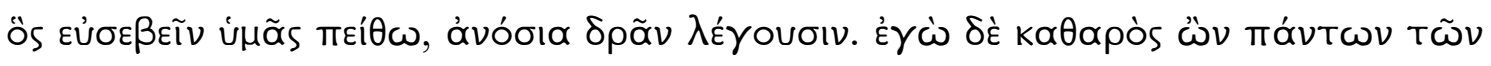

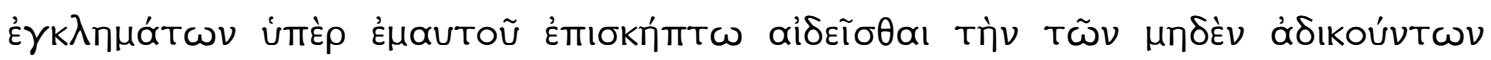

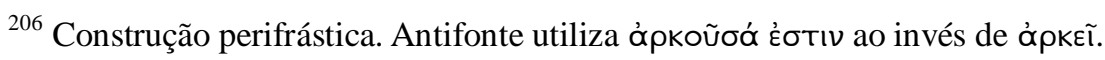




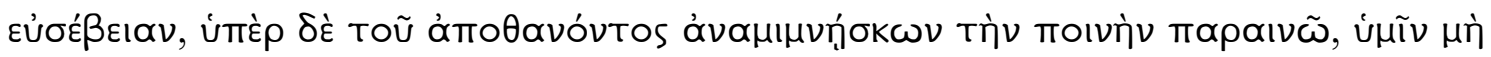

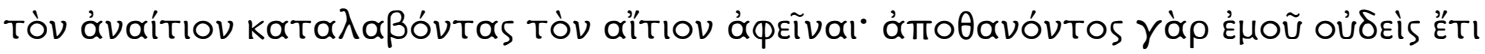

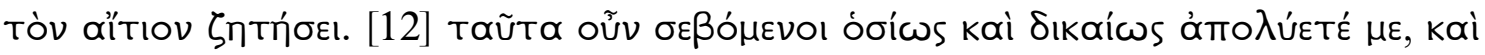

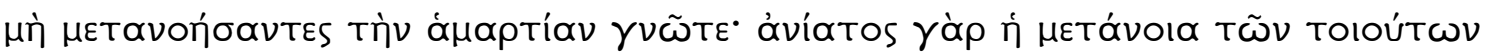
ĖoTív.

\section{4}

[1] Eis-me aqui ${ }^{207}$, eu que, espontaneamente, me entrego ao infortúnio ${ }^{208}$ - que, como eles dizem, estou culpando injustamente - e à hostilidade de meus oponentes, temendo, por um lado, a magnitude de suas acusações caluniosas, mas confiando, por outro, no julgamento dos senhores ${ }^{209}$ e na verdade das ações por mim realizadas ${ }^{210}$. Ao ser privado por eles até mesmo de lamentar diante de vocês o meu presente infortúnio, não sei $^{211}$ em que outra fonte de salvação devo buscar refúgio. [2] Efetivamente lançam contra mim acusações caluniosas as mais inauditas - as mais inauditas para não dizer as mais malditas. Pois pretendendo ser ao mesmo tempo os acusadores e os vingadores do homicídio e falando em defesa de toda suspeita verdadeira ${ }^{212}$, em razão da falta de conhecimento acerca do assassino da vítima, afirmam que sou eu o criminoso. Praticando ações contrárias às que lhes são ordenadas ${ }^{213}$, é evidente que buscam me matar injustamente ao invés de punir o assassino. [3] A mim, por outro lado, não me resta outra coisa senão me defender contra o testemunho do escravo, pois não sou o informante nem o condenador ${ }^{214}$ dos assassinos, mas, sendo acusado, respondo. Igualmente devo me empenhar a fim de demonstrar, por todos os meios, que estes aí tramam contra mim e que eu mesmo estou livre da suspeita. [4] Peço, então, que transformem o infortúnio de que se servem para me acusar caluniosamente em boa

\footnotetext{
207 iరoú: expressão dramática comum na poesia.

${ }^{208} \mathrm{O}$ réu, que, antes de pronunciar seu segundo e último discurso, poderia partir para o exílio, a fim de escapar de uma possível condenação à morte, prossegue seu discurso.

${ }^{209} \mathrm{O}$ acusado adula os juízes. Como lembra Gagarin, a adulação é comum em toda a oratória forense. (ANTIPHON, 1997, p. 140)

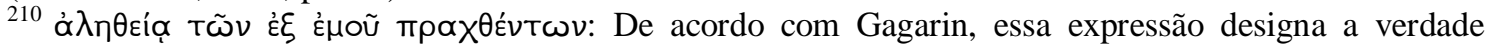
objetiva ou factual enquanto oposta às conclusões mostradas pelos argumentos da acusação (ANTIPHON, 1997, p. 140). Ela será bastante importante na Tetralogia II.

211 ámорஸ̃: a ámopía se tornaria uma declaração retórica comum. Cf. Górgias, Pal. 4; 10.

${ }^{212}$ Isto é, todos os verdadeiros suspeitos.

${ }^{213}$ Gagarin comenta acerca do dever moral de se acusar o assassino de um parente próximo. Não haveria, segundo ele, nenhuma sanção legal específica prescrita para aquele que não fizesse isso. (ANTIPHON, 1997, p. 140).

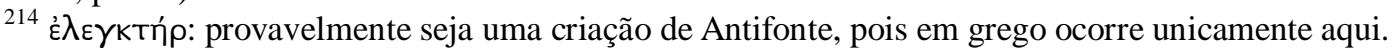


fortuna, sendo preferível que vocês me façam um homem feliz após me absolverem, ao invés de se apiedarem de mim após me condenarem.

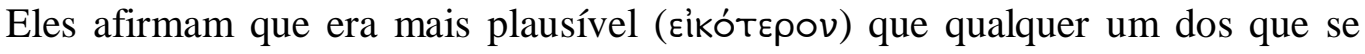
depararam com as vítimas levasse a notícia até a casa delas, depois de interrogar exaustivamente a respeito dos assassinos, ao invés de abandoná-las e partir. [5] Mas não penso que exista um homem assim tão imprudente e corajoso, que, em uma hora avançada da noite, após encontrar os cadáveres com os corpos ainda convulsionando ${ }^{215}$, não dê a volta e fuja no sentido contrário, ao invés de colocar em risco a sua vida buscando informações acerca dos malfeitores. E uma vez que os que se depararam com as vítimas fizeram o que era mais plausível (Eỉkós) que se fizesse, não seria plausível (Eikótws) serem deixados livres os que as mataram por causa de suas roupas; de modo que eu acabo desvinculado da suspeita. [6] Se alguns outros malfeitores foram, ou não, anunciados junto com o homicídio delas, quem sabe? Pois não era do interesse de ninguém investigar essas coisas. Sendo esse anúncio desconhecido, não é pouco crível

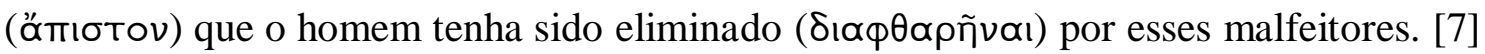
E como se pode considerar o testemunho do escravo mais confiável que o de homens livres? Pois, enquanto estes, se não parecerem estar testemunhando a verdade são desonrados com a perda da cidadania e também penalizados sobre seus bens, aquele, se não forneceu prova alguma nem um testemunho sob tortura ( $\beta a ́ \sigma a v o v)$, como se dará sua punição? Ou então, que prova haverá? ${ }^{216}$ Ele, não correndo nenhum risco ao testemunhar, não sofreu nada de terrível pelas mãos de seus senhores - que são meus inimigos - quando foi persuadido a mentir sobre mim; eu, por outro lado, sofreria coisas ímpias se, depois de ter sido objeto de testemunho não confiável, fosse morto por vocês. [8] Além do mais, dizem que é mais difícil de crer (ómıотótєроv) que eu não tenha estado presente no momento do homicídio do que tenha estado. Eu, não pelas

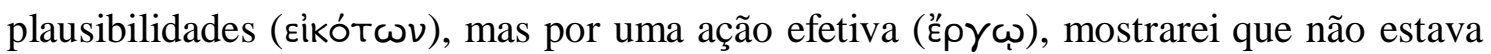
presente. Pois quantos forem meus escravos e escravas, todos ofereço para serem postos à prova sob tortura; e se eu não demonstrar que estava dormindo em casa naquela noite ou que não havia saído para algum lugar, estou de acordo, então, que sou o criminoso. Mas não se trata de uma noite desconhecida: o homem morreu nas Dipólias ${ }^{217}$. [9]

\footnotetext{
${ }^{215}$ ảorraípovøı: palavra poética e da prosa jônica. Também encontrada em Heródoto (I, 111, 16; IX, 120 , 4).

${ }^{216}$ Uma sequência de perguntas retóricas.

${ }^{217}$ Festival em Atenas em honra a Zeus Polieu, protetor da cidade.
} 
Quanto à minha riqueza, pela qual dizem que, pelo temor de perdê-la, é razoável supor

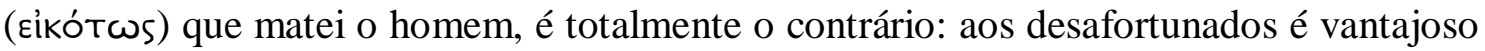

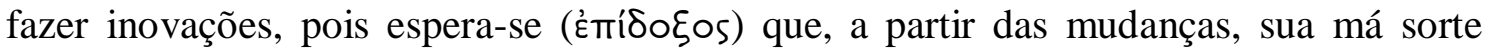
mude; enquanto aos afortunados é vantajoso permanecer tranquilos e proteger a sua presente prosperidade, pois, mudando o estado das coisas, de afortunados se fazem desafortunados. [10] Pretendendo provar minha culpabilidade pelas plausibilidades

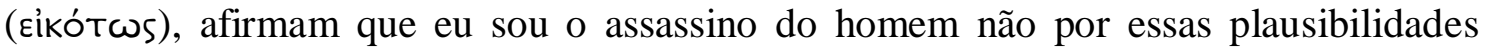

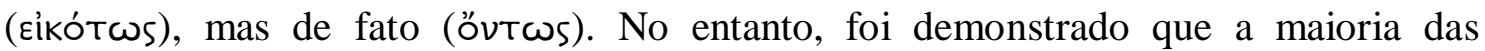

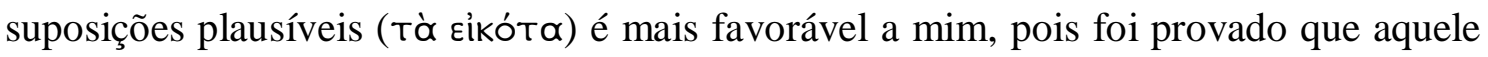
que testemunha contra mim é pouco confiável e que não pode ser colocado à prova.

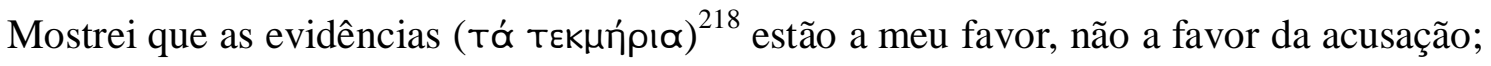
e que foi demonstrado que os rastros do homicídio não levam a mim, mas aos que são absolvidos por eles.

Tendo sido provado que toda a acusação é pouco confiável, não é o caso de que, se eu for absolvido, não haja meio pelo qual os malfeitores possam ser declarados culpados, senão de que se eu for considerado culpado, nenhuma defesa é o bastante para os que são incriminados. [11] Assim, ao me acusarem injustamente, eles, por um lado, se declaram inocentes e puros (k $\alpha \theta \alpha \rho o i ́)$, embora busquem me matar impiamente; e, por outro, dizem que eu, persuadindo vocês a agir com piedade, realizo ações ímpias. Sendo eu puro e inocente ( $k \alpha \theta \alpha \rho o ́ s)$ de todas as acusações, em meu próprio nome imploro que vocês respeitem a piedade daqueles que não agem de modo injusto; e em

\footnotetext{
${ }^{218}$ O álibi dos escravos da defesa e o uso, contra eles, do interrogatório mediante tortura.

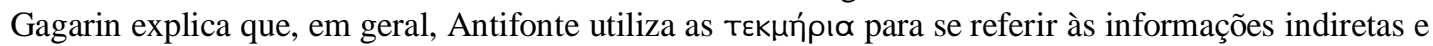

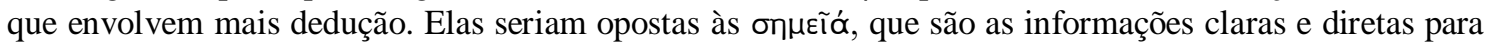
uma conclusão (ANTIPHON, 1997, p.112). Para Decleva-Caizzi, os dois termos são usados por Antifonte indiferentemente (ANTIPHONTIS, 1969, pp. 183-84). No fragmento 163 de Ammonius (Sobre as diferenças de expressão, Th.72), há uma indicação de que Antifonte faz a distinção entre onkeĩóv

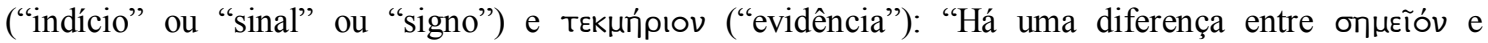

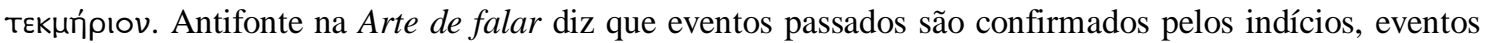
futuros são pressagiados pelas evidências"(tradução minha). Aristóteles, na Retórica (1357b1-b25), diz

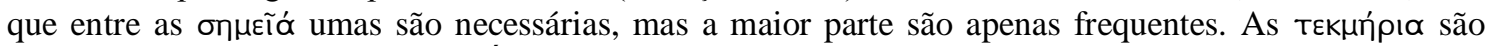

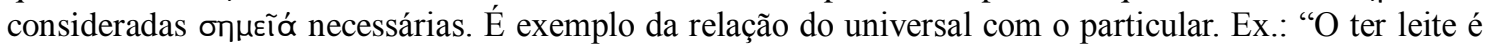
sinal de uma mulher ter dado à luz". Se para Aristóteles, o Eíós é uma premissa plausível, frequentemente verdadeira, mas nem sempre, o onнкĩóv é um indício ou sinal de que algo aconteceu ou

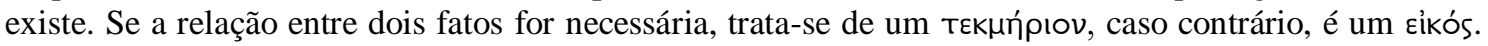

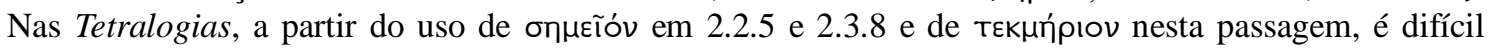

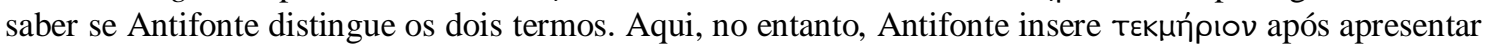

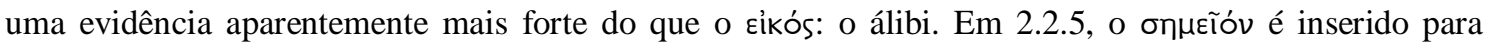
rebater um argumento do Eikós da acusação, mas a relação entre os dois fatos mencionados não é

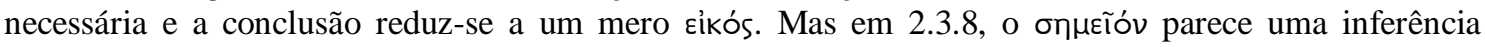
necessária tal como o exemplo acima de Aristóteles.
} 
nome do morto, lembrando a retaliação necessária, aconselho os senhores a não deixar o culpado em liberdade, condenando um inocente. Pois se eu morrer, ninguém mais procurará o culpado. [12] Portanto, temendo vocês tudo isso, absolvam-me conforme a piedade e a justiça, e não reconheçam o erro depois de se arrependerem, pois o arrependimento por tais erros é irremediável.

\subsection{Texto, tradução e notas da Tetralogia II [3]}

$$
[3.1]^{219}
$$

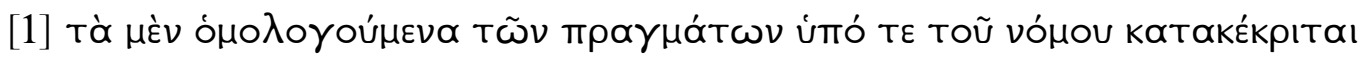

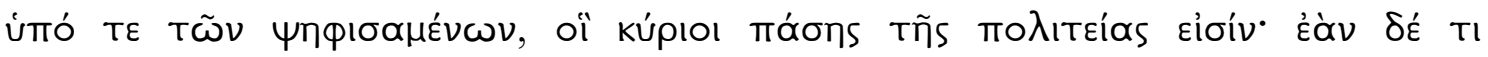

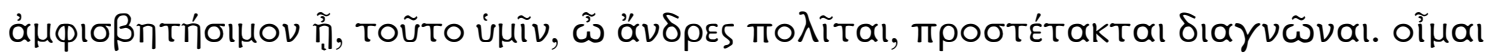

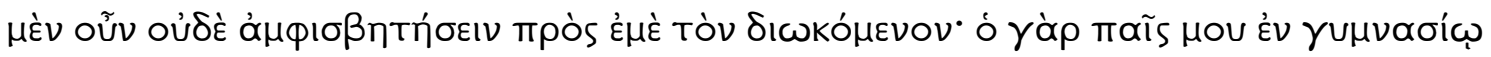

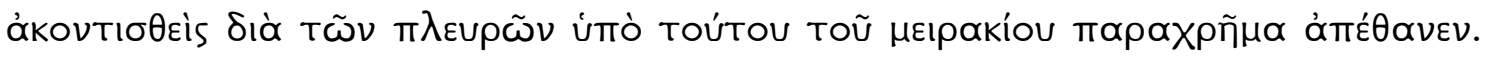

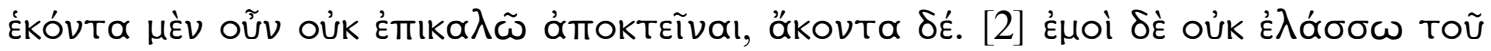

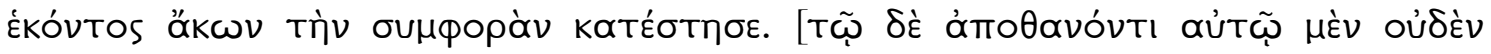

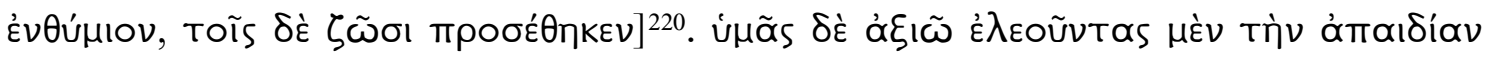

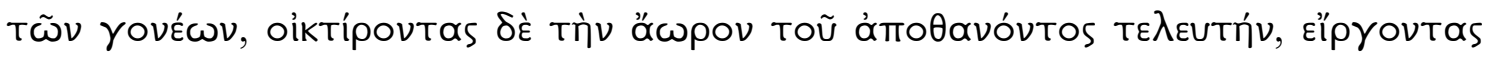

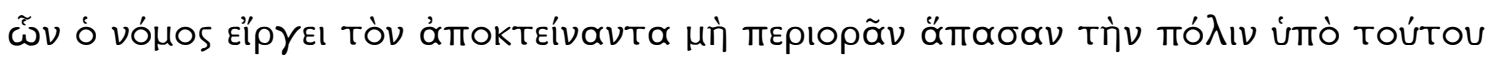

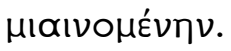

[1] Os fatos em torno dos quais há acordo são julgados tanto pela lei quanto pelos que a votaram ${ }^{221}$, que são as autoridades de toda a vida cívica. Mas se algo estiver

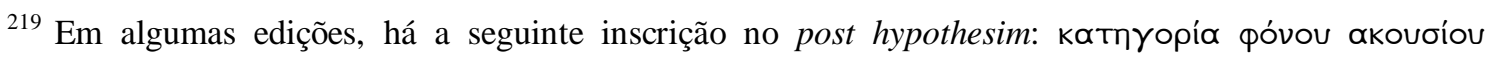
(Acusação de homicídio não-intencional).

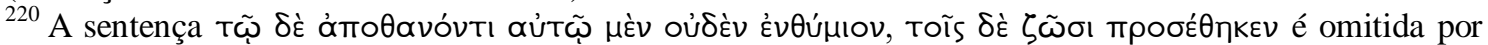
Gernet, por se tratar de uma adição desajeitada ("une adjonction maladroite"). Decleva-Caizzi (ANTIPHONTIS, 1969, p. 213), embora não omita a sentença, acredita que ela esteja deslocada e que, assim como Gernet, trata-se provavelmente de uma frase inserida posteriormente no texto. Morrison vê na sentença a possibilidade de um típico paradoxo retórico (ANTIPHON, 2001, p. 141). Já Gagarin afirma que é característico de seu orador unir uma expressão com seu oposto a fim de dar ênfase, mesmo quando desnecessária ou inapropriada (ANTIPHON, 1997, p. 147).

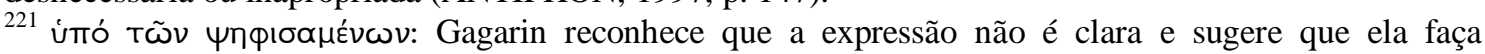
referência àqueles que no passado haviam votado na assembleia para aprovar as leis (ou decretos)
} 


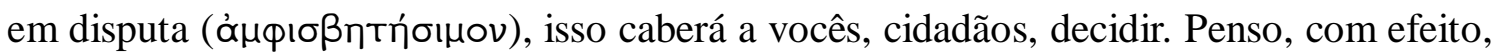

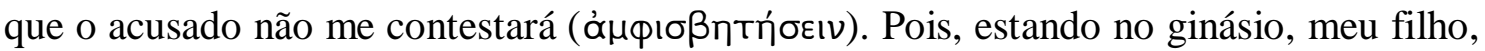
ao ser atingido no meio de suas costas pela lança atirada por esse jovem ${ }^{222}$, morreu de

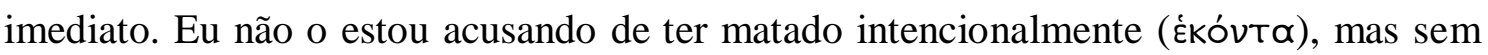

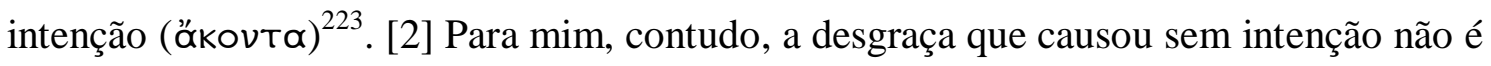
menor que a que tivesse sido causada intencionalmente ${ }^{224}$. [Além do mais, ao próprio morto não impôs nenhuma pesada preocupação ${ }^{225}$, mas sim aos vivos]. Peço a vocês, que, apiedando-se dos pais privados de seus filhos e compadecendo-se do fim prematuro da vítima, expulsem o assassino dos lugares de onde a lei (vónos) expulsa ${ }^{226}$ e não permitam que a cidade toda seja contaminada por ele.

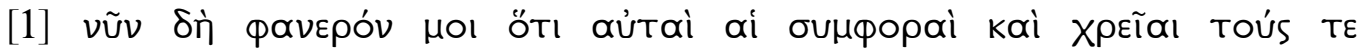

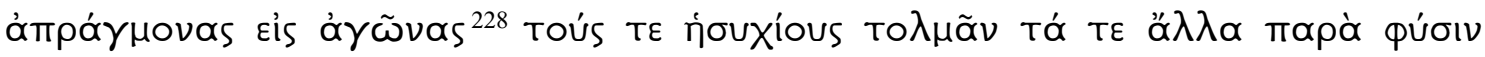

(ANTIPHON, 1997, p. 146-47). A tradução de Decleva-Caizzi do termo por "juízes" talvez não esteja correta, pois elimina a construção antitética criada entre os fatos que são decididos pelas leis e por aqueles que as votaram no passado e os fatos que são decididos pelos cidadãos na condição de juízes, passagem que será mencionada um pouco mais a frente (ANTIPHONTIS, 1969, p. 211). A tradução do termo

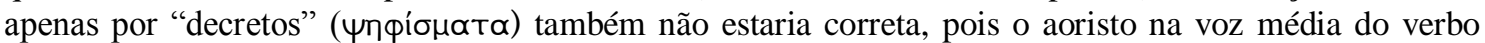
$\psi \eta \emptyset i ́ \sigma \zeta \omega$ não teria valor de passivo. Optamos pela solução de Gagarin e traduzimos a expressão por "pelos que a (lei) votaram".

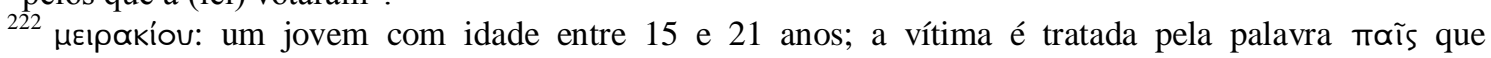
traduziremos por "garoto", pois seria alguém com idade de até 14 anos.

${ }^{223}$ Já neste discurso, a acusação indica que se trata de um homicídio não-intencional (ǻ́kwv), de competência do Paládio, caso fosse efetivamente apresentado em um tribunal. Os termos ékóvta e ăkovta recebem, logo no início da Tetralogia II, forte destaque. Optamos por traduzi-los por "intencionalmente" e "não-intencionalmente", mas em algumas traduções é possível encontrar como

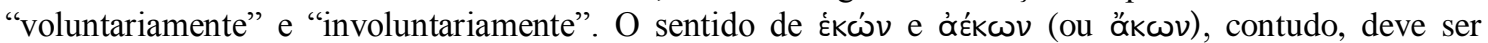
entendido, respectivamente, como relacionado à uma ação derivada da intenção ou não de alguém fazer algo. Gagarin defende que traduzi-los por "acidental" ou "não-acidental", não estaria correto, pois um argumento sobre essas bases, segundo ele, não teria nenhum peso legal em um mundo hipotético como o da Tetralogia II, e provavelmente nem na Atenas do século V a.C. (GAGARIN, 2002, p. 119).

${ }^{224}$ Acredita-se que a necessidade de compensação ou punição era exigida nas sociedades antigas a quem causasse prejuízo a outra pessoa, independentemente da intenção de fazer tal ação danosa.

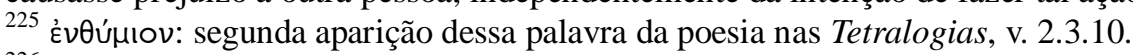

${ }^{226} \mathrm{~A}$ lei em questão se refere à exclusão do assassino dos lugares públicos e religiosos, a fim de evitar a contaminação da cidade com sua presença. No caso do homicídio não-intencional, um banimento temporário. Uma evidência dessa lei pode ser encontrada em Platão, Leis IX 865e:“A fábula diz que o homem assassinado violentamente que tenha vivido uma vida livre e orgulhosa se irrita com seu matador quando recentemente morto, e ademais cheio de medo e horror em função de seu próprio fim brutal, ao ver seu assassino viver segundo os mesmos costumes em que ele vivia [e frequentar os mesmos lugares] é assaltado pelo maior horror, e nesse estado de intranquilidade, identificando-se com seu assassino, ele the transmite com todas as suas forças sua própria intranquilidade, afetando tanto a alma quanto as ações do assassino". (PLATÃO, 1999, p. 373). Cf. Demóstenes 20.158.

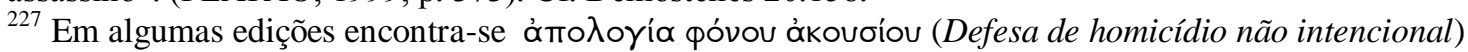




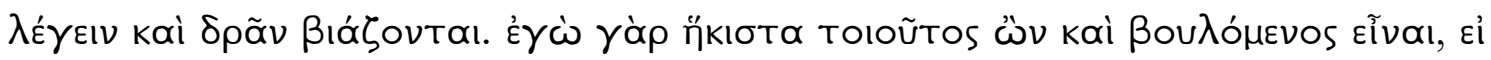

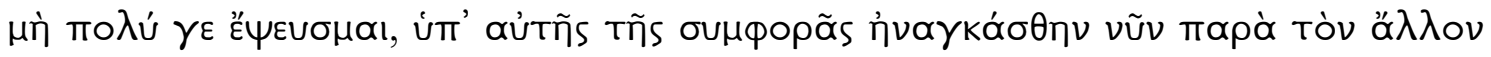

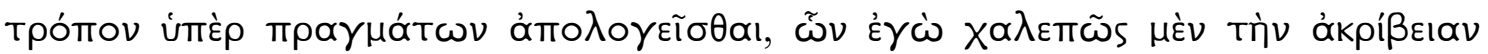

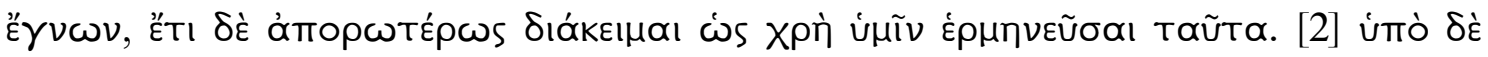

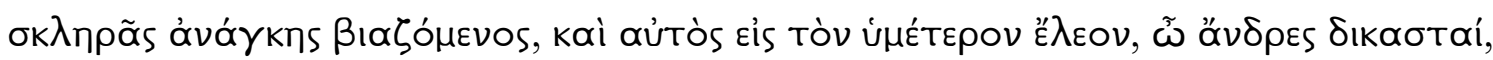

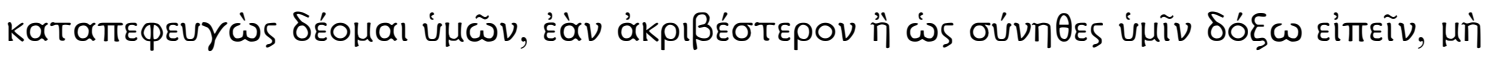

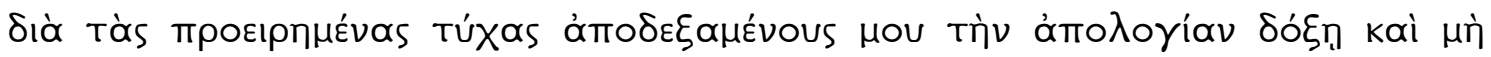

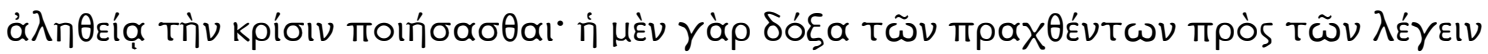

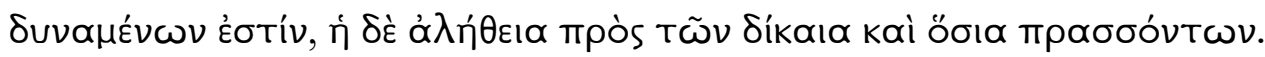

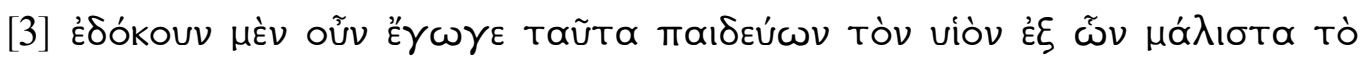

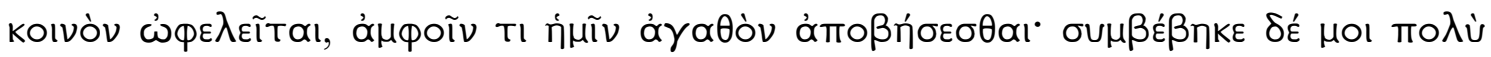

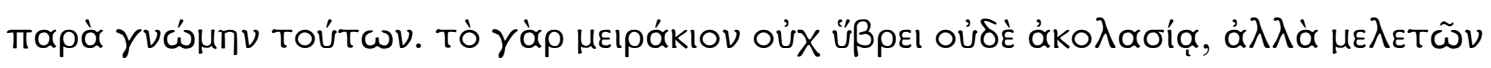

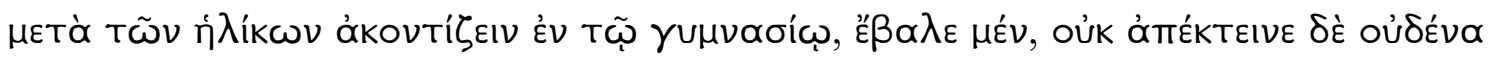

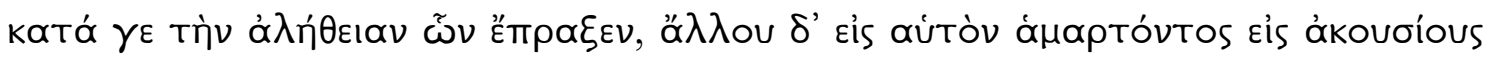

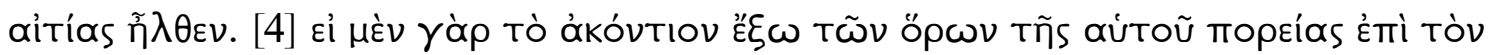

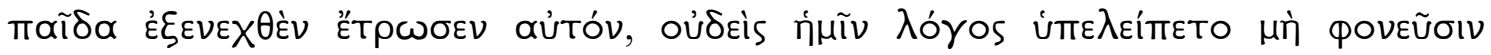

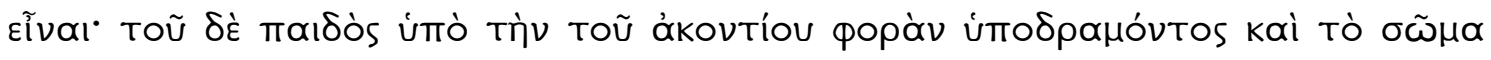

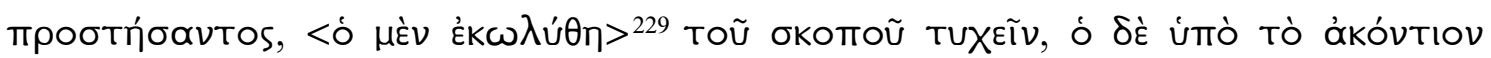

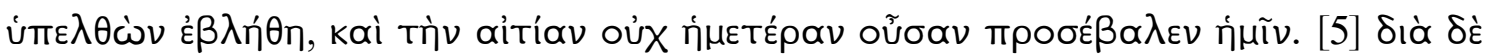

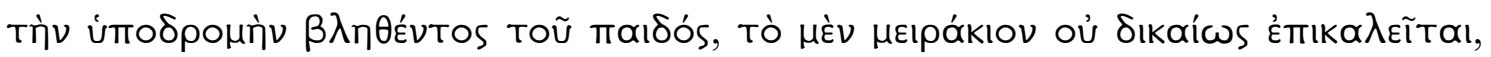

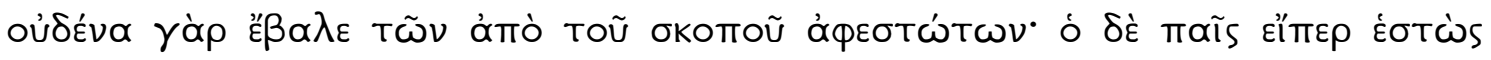

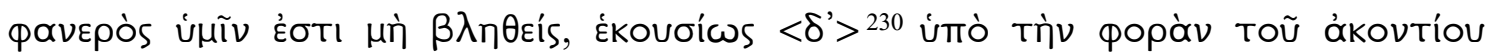

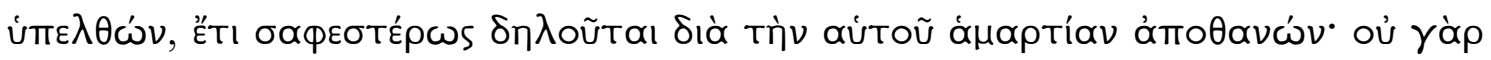

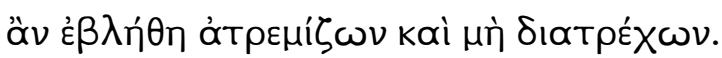

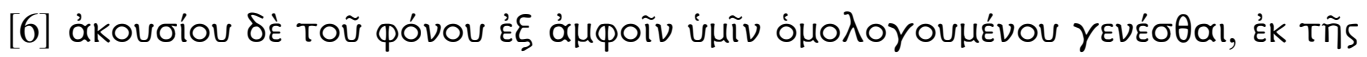

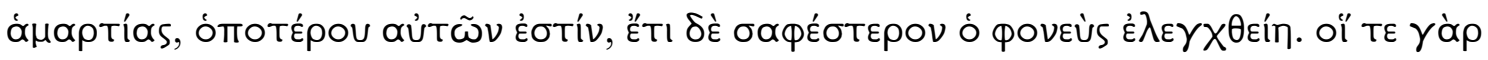

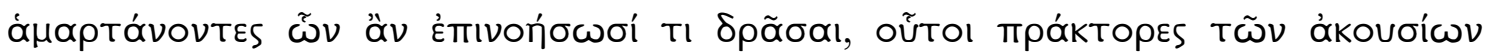

\footnotetext{
${ }^{228}$ Alguns editores, caso de Gernet, inserem o verbo kataotñvaı. Tal inserção seria justificada pela necessidade desses editores em criar uma simetria na sentença, o que para Decleva-Caizzi, não parece necessária (ANTIPHONTIS, 1969, pp. 214-15). Além disso, é possível encontrar uma sentença semelhante em 4.1.1., que reforçaria o acréscimo do verbo. Gagarin, a exemplo de Decleva-Caizzi, não vê necessidade da inserção (ANTIPHON, 1997, p. 148).

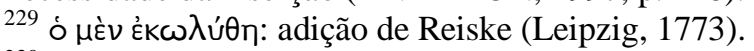

${ }^{230} \delta^{\prime}$ : adição de Blass (Leipzig, 1881).
} 


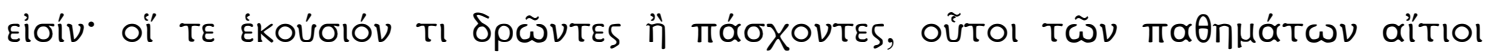

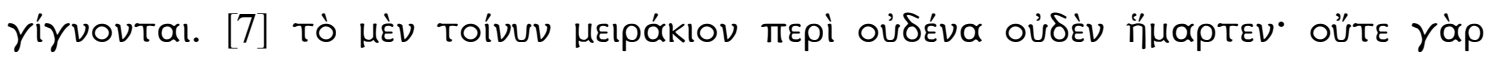

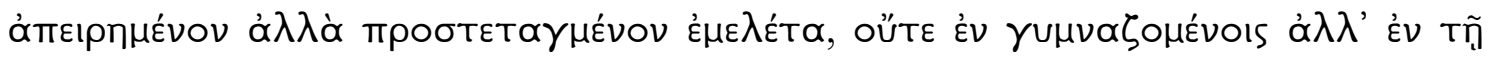

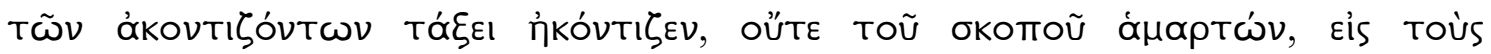

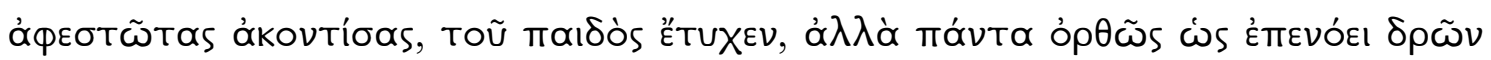

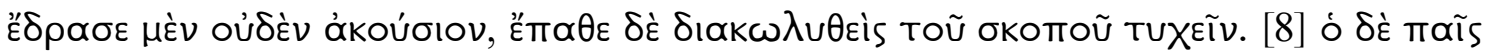

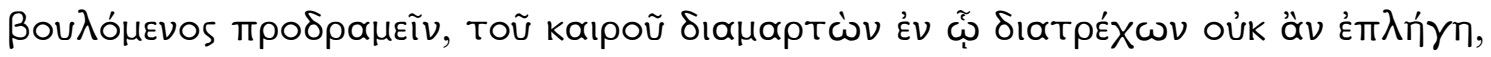

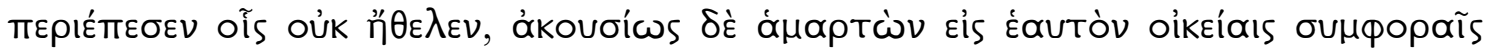

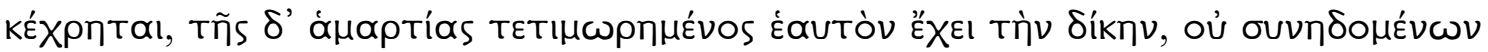

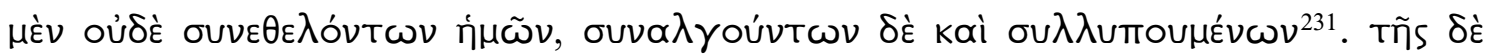

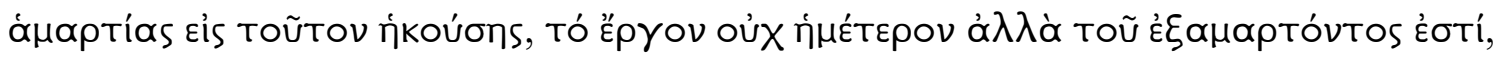

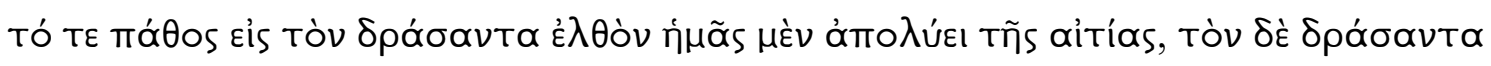

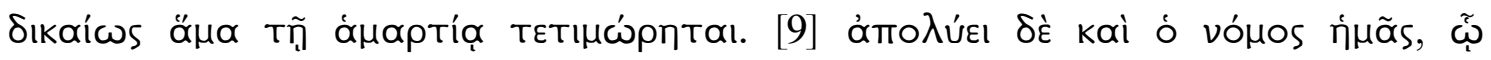

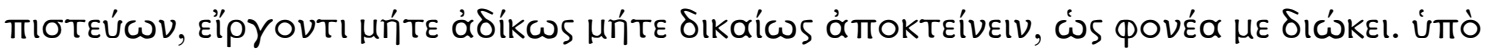

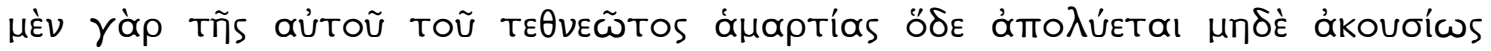

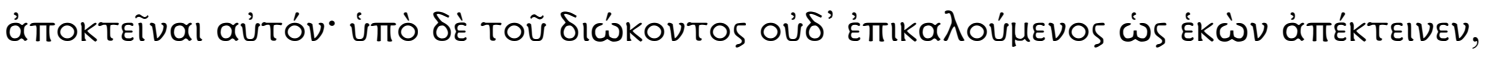

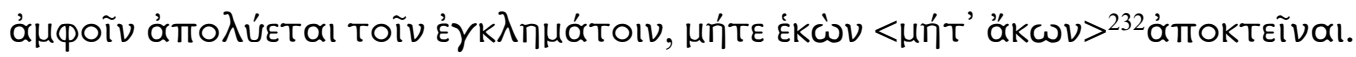

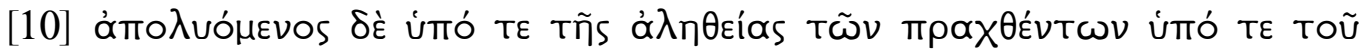

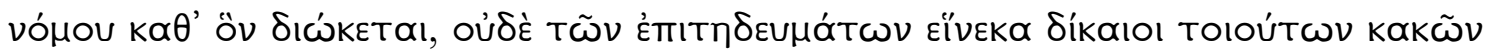

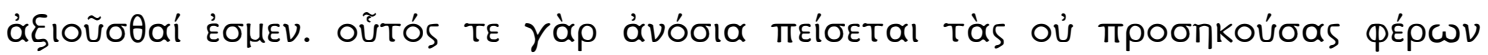

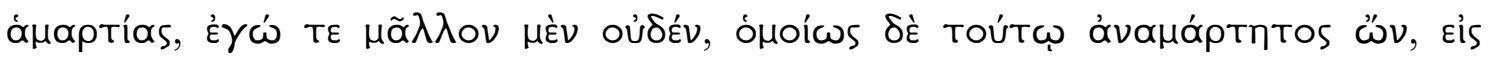

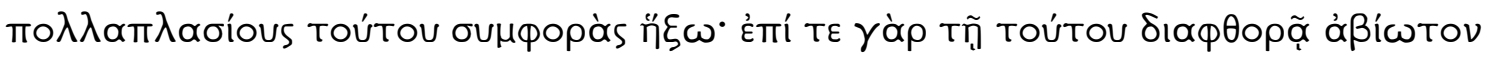

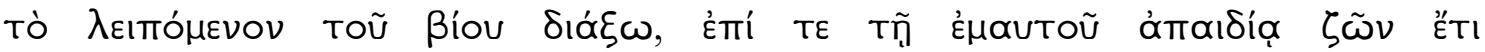

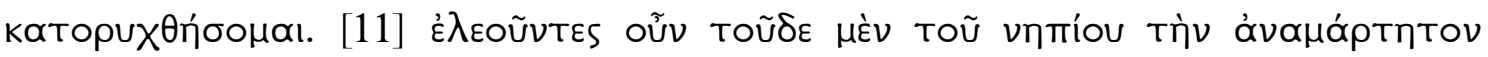

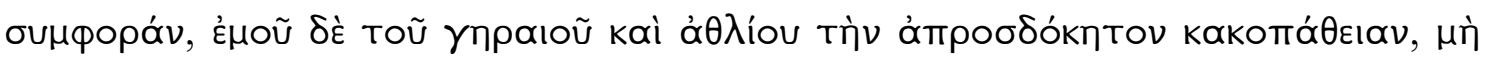

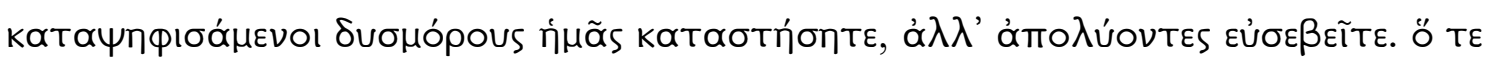

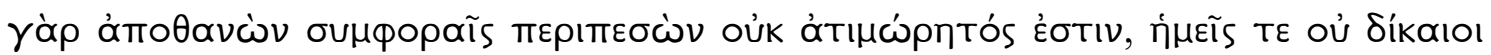

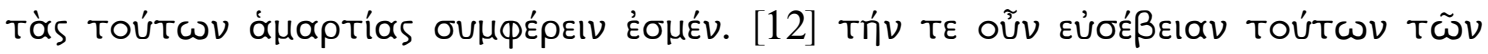

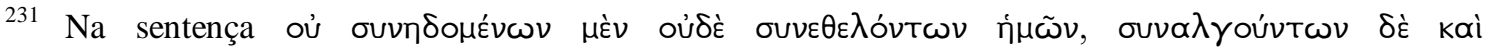
бu$\lambda \lambda \cup \pi \operatorname{u} \mu \varepsilon^{\prime} v \omega \nu$ ("não nos alegrando nem querendo tal coisa, mas compadecendo da dor e nos mortificando por isso") é possível encontrar dois tipos de paralelismo: parísosis (oração de dimensão similar: dois pares de particípios separados por uma conjunção) e paromoíosis (sons similares entre os dois pares de particípios).

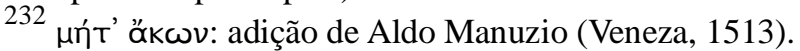




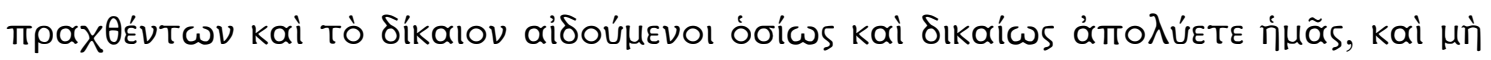

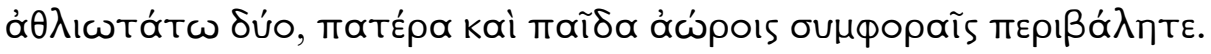

[1] Neste exato momento, fica claro para mim que as próprias desgraças e necessidades forçam os homens não atuantes ao debate, e os que são tranquilos, a serem audazes e até mesmo a falar e a agir contra sua natureza ${ }^{233}$. Pois eu, não sendo e nem querendo ser tal tipo de homem, ao menos que eu esteja muito enganado, sou agora, por esta desgraça ${ }^{234}$, obrigado a fazer, contra meu modo habitual de ser, a defesa sobre fatos

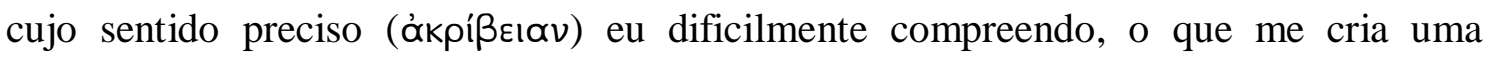

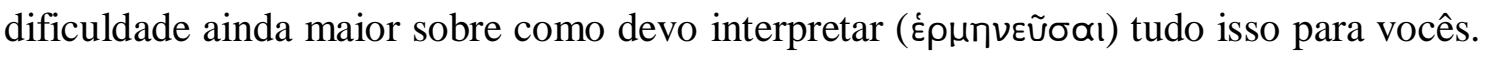
[2] Sendo forçado por uma inflexível necessidade ${ }^{235}$, também eu mesmo apelo a vocês, juízes, buscando refúgio em sua piedade, que se parecer aos senhores que, por causa da

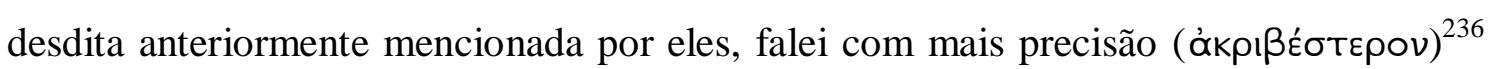
do que o habitual, não tomem sua decisão sobre minha defesa segundo a aparência

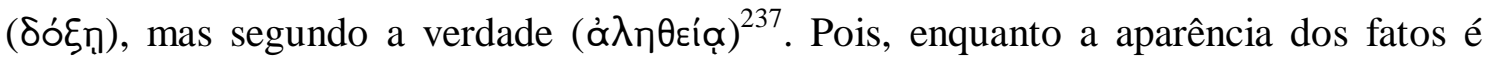
favorável àqueles que são capazes de falar, a verdade é favorável àqueles que realizam ações justas e piedosas ${ }^{238}$.

[3] Pois bem, eu mesmo pensava que, ensinando a meu filho aquelas atividades pelas quais o Estado obtém os maiores benefícios, resultaria em algum bem para nós dois. Mas aconteceu para mim totalmente o contrário do que esperava. Pois o jovem,

\footnotetext{
${ }^{233}$ Tanto ómpáyuovas quanto j̇ouxíous são palavras que designam o cidadão que evita os tribunais. Antifonte cria um દ’قos (caráter) do orador: enquanto passa aos juízes a imagem de um orador inexperiente, desenvolve argumentos habilidosos. A declaração de ser um homem quieto, não acostumado à litígios, inexperiente do ponto de vista legal viria a ser um topos da oratória grega e latina.

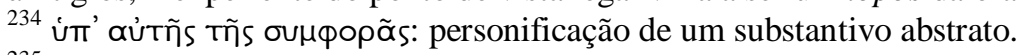

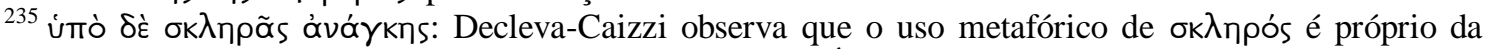
tragédia (ANTIPHONTIS, 1969, p. 215-16). Cf. Sófocles, Édipo em Colono, v. 774 e 1406.

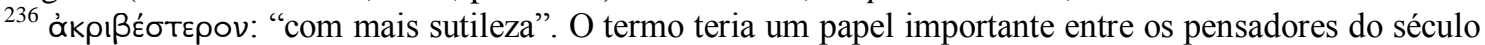
V a.C. Na Tetralogia II, a busca pelo "sentido preciso" é importante, uma vez que o fato não está em disputa, mas sim a interpretação precisa desse fato.

${ }^{237}$ Também presente nessa Tetralogia, em que os fatos são claros, mas está em disputa a sua "verdade" ou a "interpretação correta" desses fatos, é o contraste entre $\delta o ́ \xi \alpha$ e ởń $\theta \varepsilon ı \alpha$, um tópico importante do século V a.C. Cf. Górgias, Pal. 24.

${ }^{238} \mathrm{O}$ topos da captatio benevolentiae está presente nesse proêmio. Trata-se de recurso retórico em que o litigante apela para a boa vontade dos juízes visando conquistar a sua simpatia.
} 


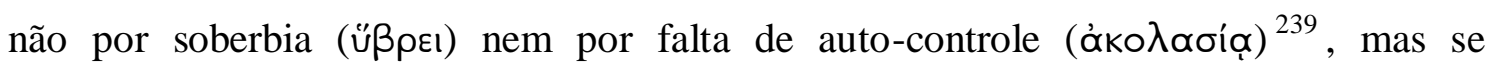
exercitando no ginásio, ao atirar lanças em companhia de outros jovens de mesma idade, de fato lançou, mas não matou ninguém conforme a verdade do que ele fez. Haja vista que o outro errou (áuaptóvtos) contra si mesmo, sobreveio-lhe a responsabilidade pelo homicídio não-intencional. [4] Pois se a lança, fora dos limites de seu próprio curso, tivesse sido lançada contra o garoto e o tivesse ferido, então nenhum argumento teria restado para nós senão o de sermos os assassinos. No entanto, dado que o garoto correu sobre os limites da trajetória da lança e frente a ela posicionou seu corpo, enquanto esta não alcançou sua meta ${ }^{240}$, aquele, porque avançou sobre sua trajetória, foi atingido, de modo que, embora a responsabilidade não seja nossa, ele a lançou contra nós. [5] Visto que o garoto foi atingido por causa de sua ação de correr na trajetória da lança ${ }^{241}$, o jovem é acusado injustamente, pois ele não atingiu nenhum dos que estavam afastados da meta do lançamento. E se é evidente para vocês que o garoto não foi atingido enquanto estava parado, mas porque avançou intencionalmente sobre a trajetória da lança, isso mostra ainda mais claramente que morreu por causa de seu próprio erro ( $\dot{\alpha} \mu \alpha \rho \operatorname{cí}^{\alpha} \nu$ ), pois não teria sido atingido se tivesse ficado parado e não correndo de um lado para o outro.

[6] Uma vez que ambos os lados, como vocês veem ${ }^{242}$, concordam se tratar de um homicídio não-intencional, descobrindo qual dos dois é o responsável pelo erro, o assassino poderia ser incriminado ainda mais claramente. Pois enquanto os que cometem um erro quando planejavam fazer alguma coisa, são os executores ${ }^{243}$ das ações não-intencionais, aqueles que fazem ou sofrem algo intencionalmente, tornam-se os responsáveis pelos males sofridos. [7] Ora, o jovem não cometeu nenhum erro contra alguém, pois ele se exercitava fazendo não o que era proibido, mas o ordenado; lançava

\footnotetext{
${ }^{239}$ Gagarin destaca o modo como a defesa organiza seu argumento contrastando dois tipos de comportamento atribuídos ao jovem culpado: agir em um caso de homicídio dominado pela arrogância (üßpıs) indicaria, segundo ele, um homicídio intencional; e agir em um caso de homicídio sem o auto-

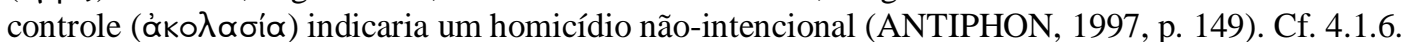

${ }^{240}$ A competição do lançamento de lanças, para os gregos, estava relacionada à distância e não à precisão. Tratava-se de um longo lançamento em uma área delimitada e não em um alvo específico. Por isso, traduzimos okoтtós por "meta" ou "área de lançamento" e não "alvo".

${ }^{241}$ Segundo Decleva-Caizzi, a negligência do garoto é a verdadeira causa. Ela defende que Antifonte teria introduzido pela primeira vez um princípio, para nós evidente: a separação da ação como movimento físico do resultado obtido, abrindo o caminho para que a "negligência" fosse incluída entre as formas de culpabilidade (ANTIPHONTIS, 1969, p. 218).

${ }^{242}$ ưuiv: um dativo de referência.

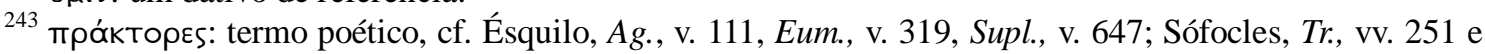
861, El., v. 953.
} 
não entre os que se exercitavam no ginásio, mas no lugar demarcado para os lançadores; atingiu o garoto não ao errar a área de lançamento, atirando a lança contra os que estavam afastados, mas fez corretamente tudo o que havia concebido ${ }^{244}$, tudo intencionalmente, e foi prejudicado ao ser impedido de alcançar a meta. [8] Por outro lado, o garoto, desejando correr, ainda que errando o momento exato no qual não teria sido ferido mesmo se corresse de um lado para o outro, caiu em uma desgraça que ele não desejava, e errando de modo não-intencional contra si mesmo, acabou encontrando sua própria desgraça. Ele faz justiça ao punir a si mesmo pelo erro cometido, não nos alegrando nem querendo tal coisa, mas nos compadecendo de sua dor e nos

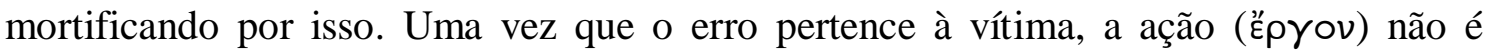
nossa, mas do autor do erro; e o sofrimento que sobreveio àquele que o praticou nos absolve da responsabilidade. Com justiça, o autor é punido simultaneamente com o erro cometido. [9] E também a lei (vónos) nos absolve - aquela que pró́be matar justa e injustamente $^{245}$ e pela qual ele acredita que me persegue como assassino. Pois, por causa do erro do próprio morto, o jovem é absolvido da acusação de tê-lo matado sequer de modo não-intencional; e por causa do acusador, que nem mesmo o acusa de ter matado intencionalmente, ele é absolvido de ambas as acusações: a de homicídio nãointencional e intencional.

[10] Ao sermos absolvidos tanto pela verdade dos fatos como pela lei ${ }^{246}$, segundo a qual o jovem é acusado, não é justo que, por causa de nossa conduta, sejamos julgados dignos de tais prejuízos. Pois o jovem sofrerá ações ímpias ao carregar o erro que não é seu; e eu, que sou tão inocente quanto ele, mais do que ninguém serei levado à desgraças muito maiores do que as dele, pois, por causa da destruição ${ }^{247}$ de meu filho,

\footnotetext{
${ }^{244}$ A defesa utiliza três antíteses para enfatizar a inocência de seu filho. Cada uma delas é construída com

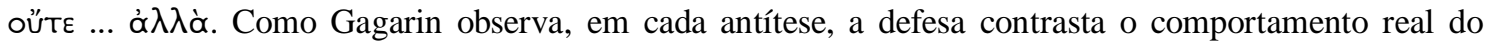
jovem com as ações hipotéticas que o teriam feito responsável pela morte (ANTIPHON, 1997, p. 151).

${ }^{245}$ A princípio, essa lei, que aparecerá também em 3.3.7 e, na Tetralogia III, em 4.2.3 e 4.4.8, seria estranha ao ordenamento legal ateniense do período. Gagarin comenta que, embora pareça contraditória uma lei que proíba o homicídio justo ou injusto, deve-se entendê-la como proibindo homicídio intencional e não-intencional (ANTIPHON, 1997, p. 151). Mas talvez uma explicação possível seja entender essa lei do ponto de vista da crença religiosa de que o assassinato, de qualquer tipo, implica a retirada de uma vida e uma impiedade contra os deuses. Logo, deve ser proibido. Essa visão ficará bastante evidente, sobretudo, na Tetralogia III.

${ }^{246}$ A lei que proíbe matar justa e injustamente.

${ }^{247}$ Alguns comentadores, como Decleva-Caizzi (ANTIPHONTIS, 1969, p. 221) e Gagarin (ANTIPHON,

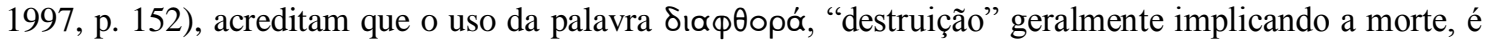
um exagero intencional de Antifonte, uma ênfase patética e dramática, pois, em caso de condenação, a pena seria o exílio e não a morte, que é o que a palavra expressaria. $\mathrm{O}$ uso da palavra, porém, não seria um exagero se analisado não do ponto de vista da lei de homicídio ateniense, mas do ponto de vista da
} 
levarei uma vida invivível pelos restos de meus dias e, por causa de sua ausência, serei enterrado, ainda que vivo ${ }^{248}$. [11] Apiedando-se, então, desse menino, que é inocente nessa desgraça, e de mim, um velho homem e miserável, em meu sofrimento inesperado, não nos tornem mal afortunados ${ }^{249}$ depois de votarem nossa condenação, mas sejam piedosos nos absolvendo, pois o morto não está sem vingança pela desgraça que lhe sobreveio e não é justo que nós carreguemos ${ }^{250}$ os seus erros. [12] Respeitando, portanto, a piedade e a justiça desses fatos, absolvam-nos de modo piedoso e justo ${ }^{251}$, e não envolvam dois grandes miseráveis, pai e filho, em desgraças prematuras.

\section{$3.3^{252}$}

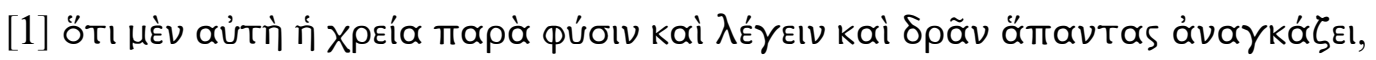

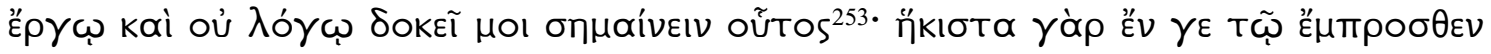

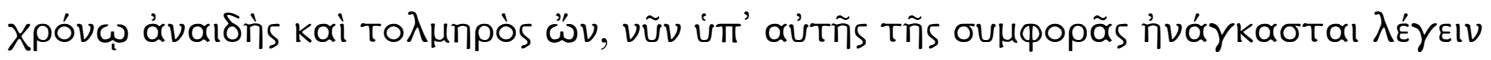

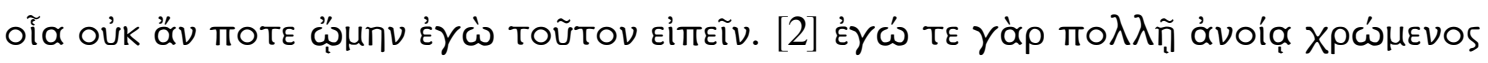

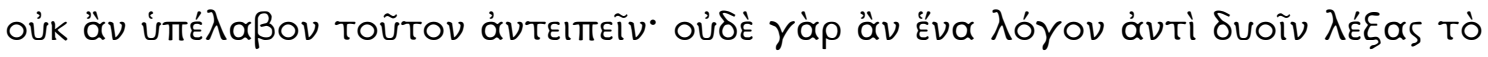

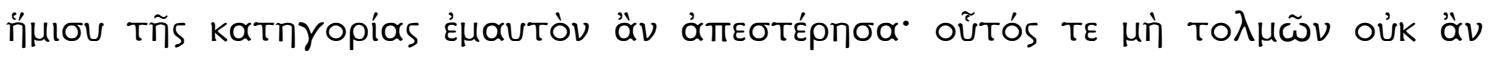

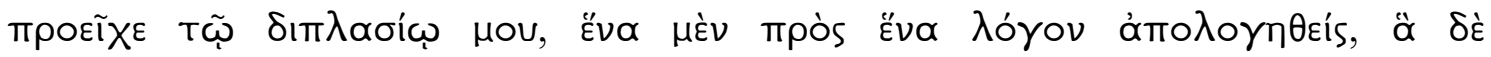

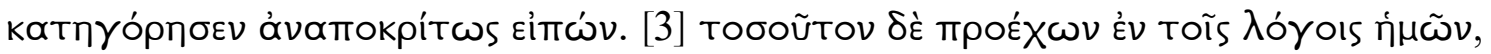

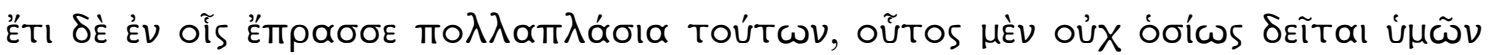

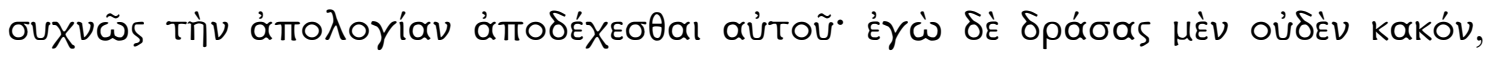

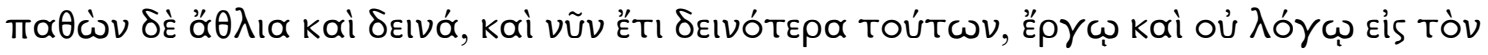

mesma crença religiosa que proíbe qualquer tipo de homicídio. No âmbito religioso, trata-se de um ato de impiedade e o responsável sofrerá as consequências. Vale lembrar que uma das peculiaridades das Tetralogias é justamente a conexão entre as esferas divina e humana e que Antifonte faz uso de uma visão religiosa bastante elaborada do miasma ao mesmo tempo em que elabora seus argumentos legais.

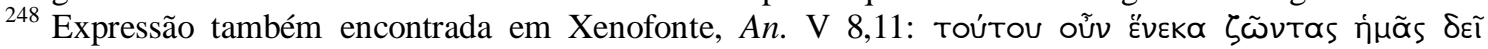

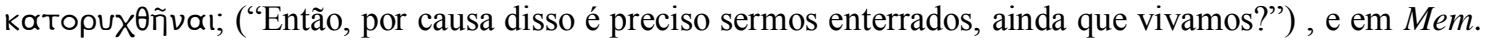

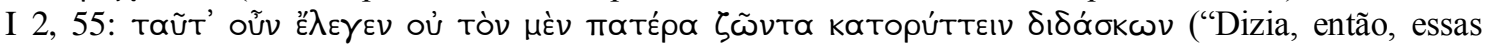
coisas, não ensinando a enterrar um pai ainda vivo").

${ }^{249}$ Svøuópous: vocabulário da poesia.

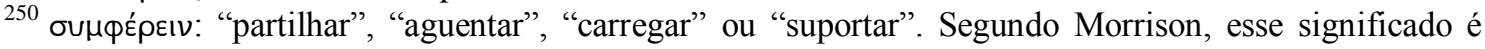
comum apenas na tragédia (ANTIPHON, 2001, p. 150). Gagarin comenta que esse sentido é encontrado primeiro na tragédia e que Antifonte, nesse ponto, teria buscado um efeito trágico, que o ouнфopaĩs, apresentado um pouco antes, reforçaria (ANTIPHON, 1997, p. 152).

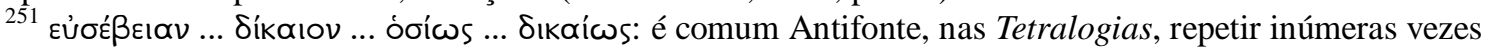
e de maneira conjunta os aspectos legal e o religioso.

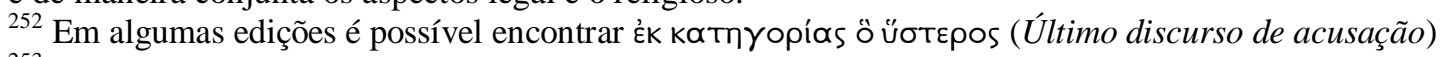

${ }^{253}$ Uma sentença iniciada com ötı seguido do verbo principal (ठокЕ̃̃). 


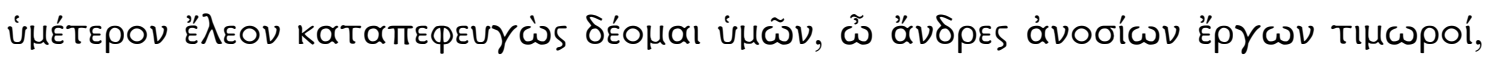

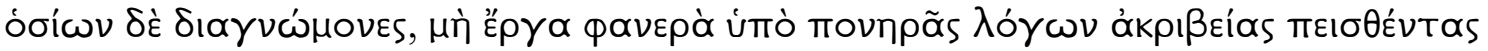

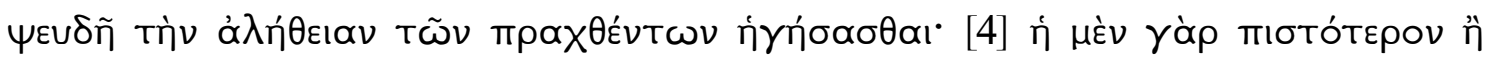

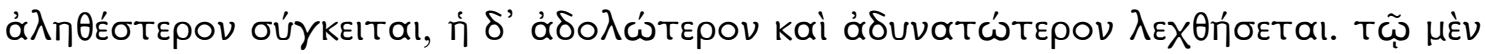

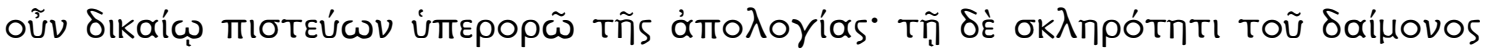

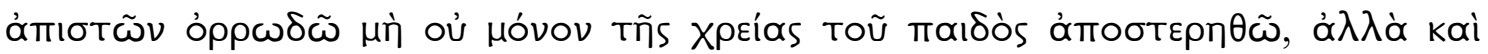

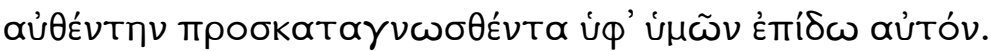

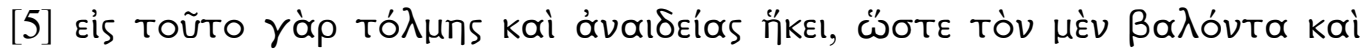

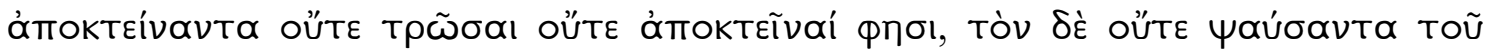

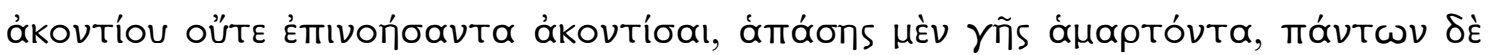

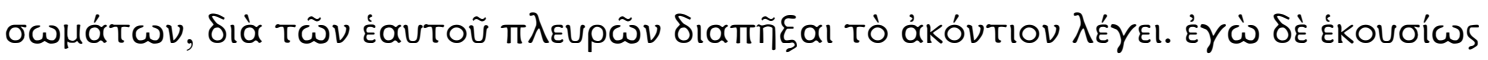

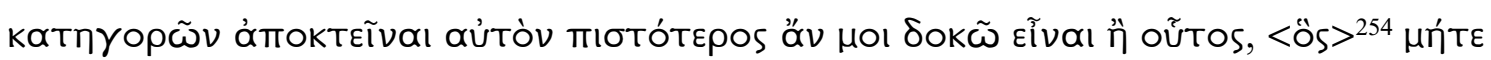

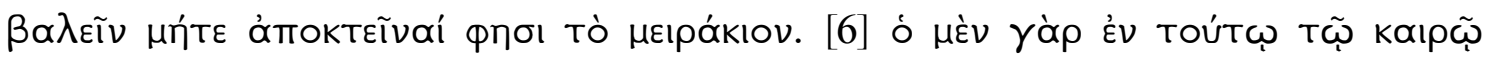

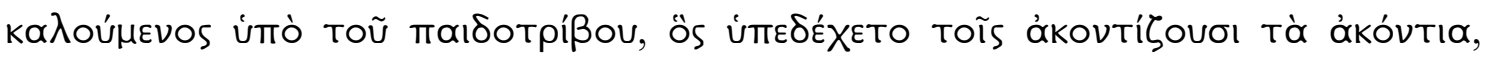

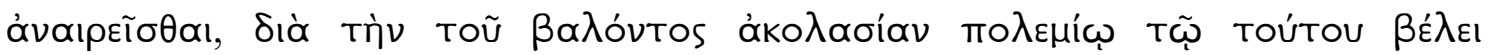

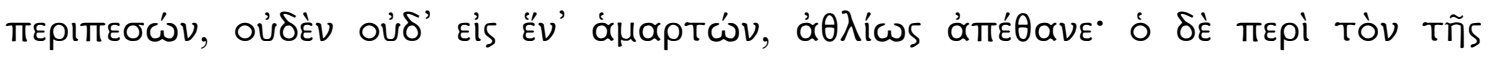

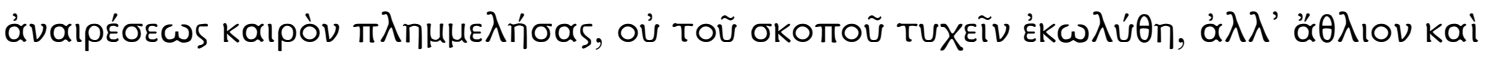

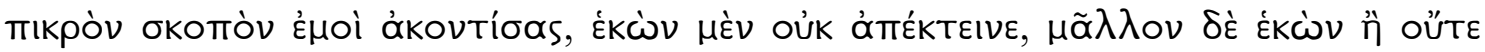

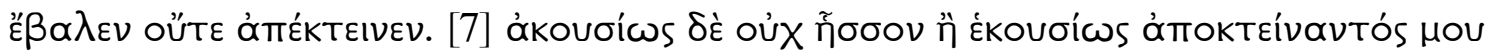

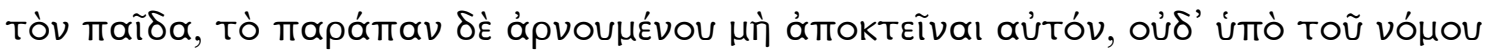

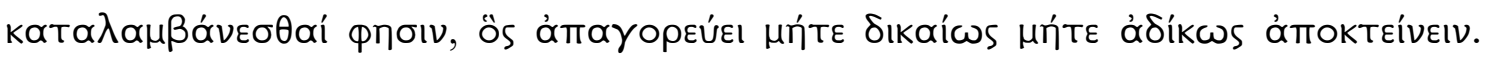

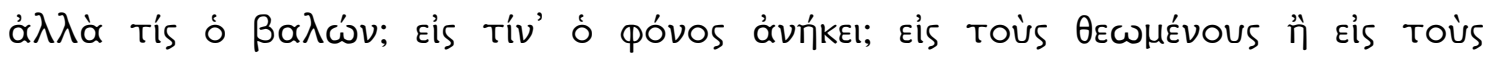

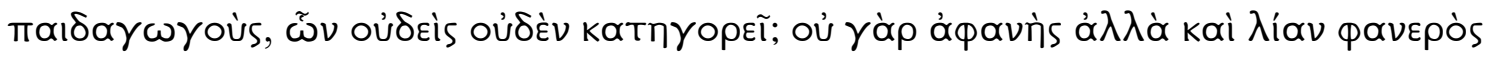

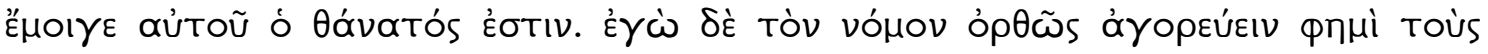

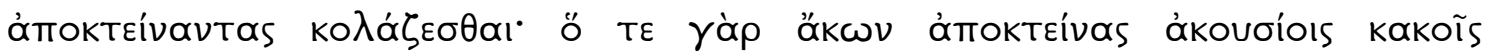

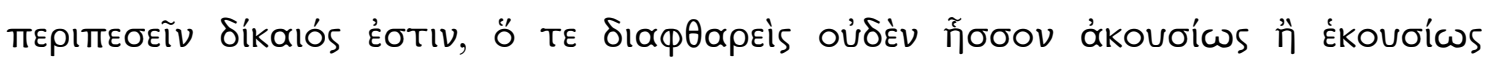

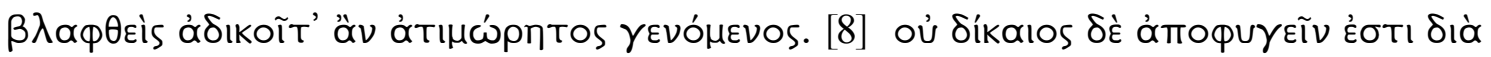

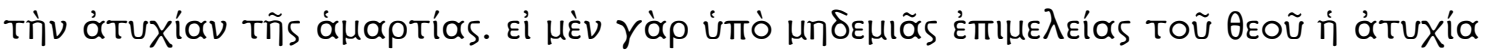

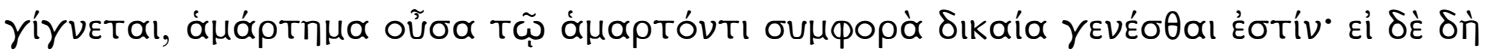

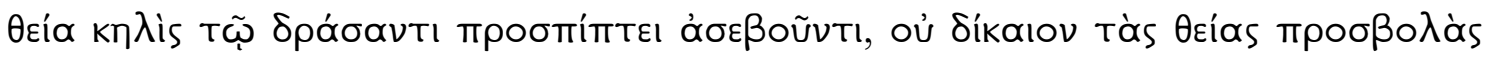

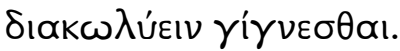

254 òs: adição de Aldo Manuzio (Veneza, 1513). 


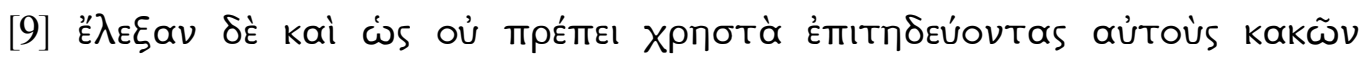

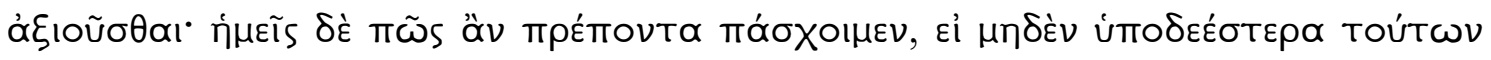

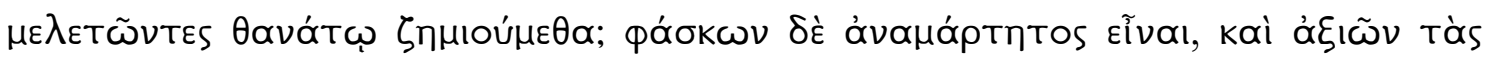

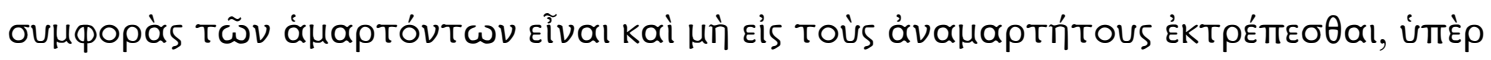

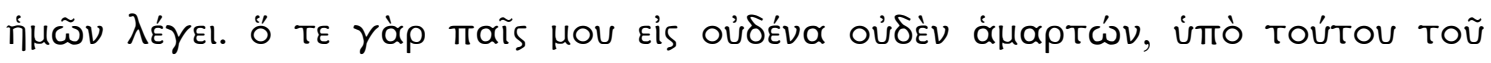

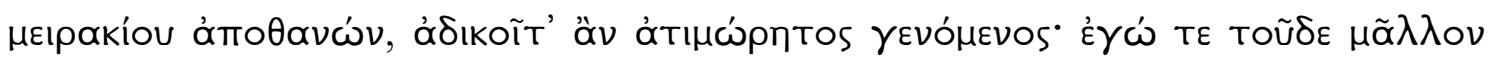

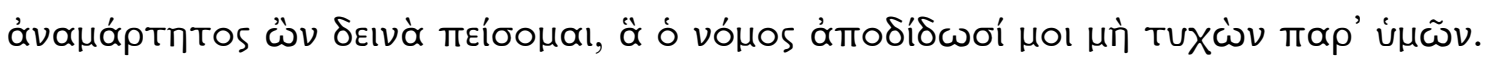

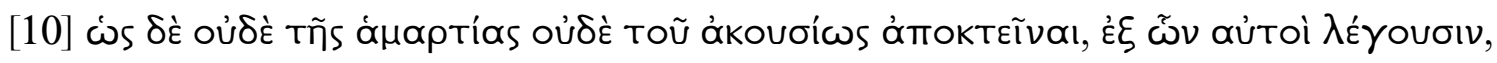

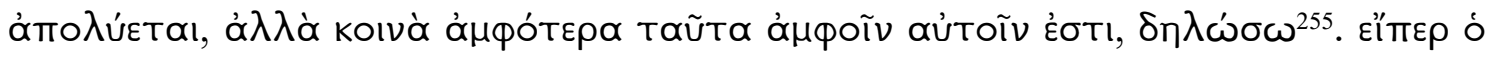

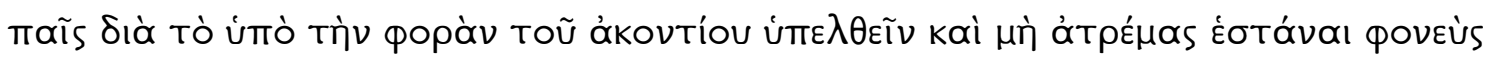

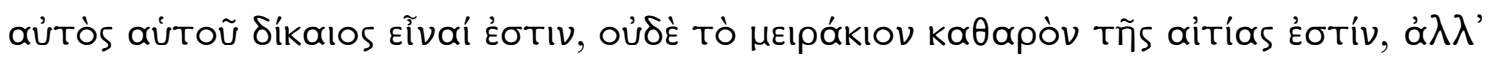

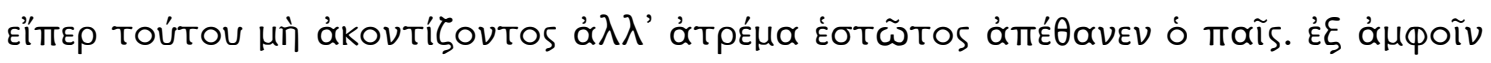

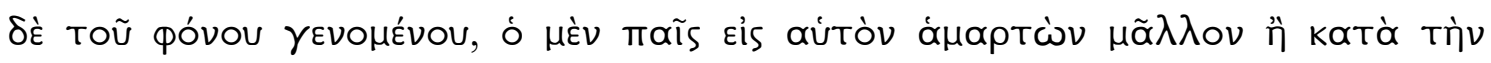

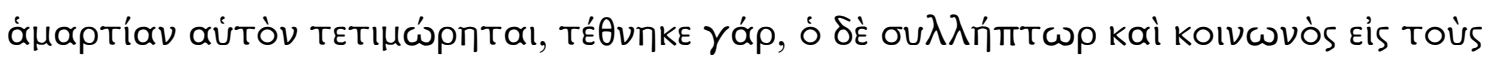

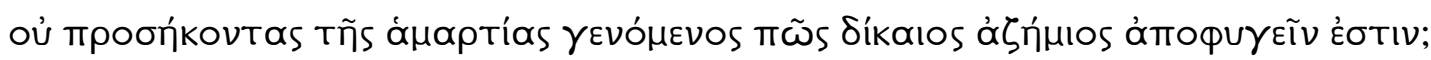

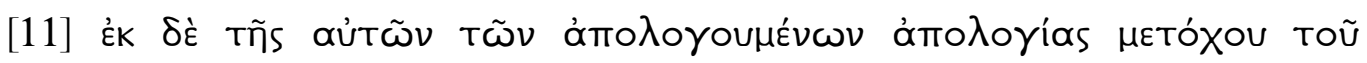

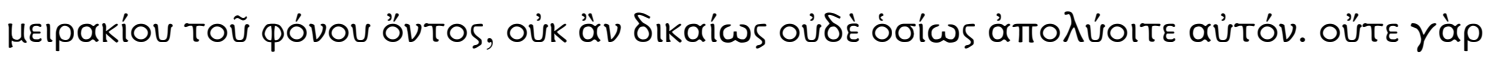

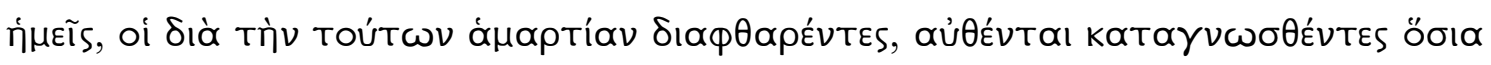

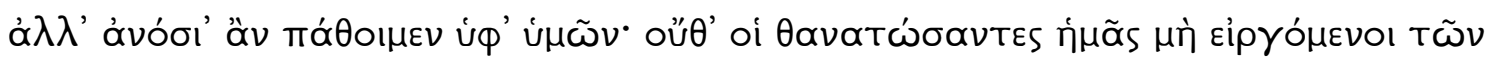

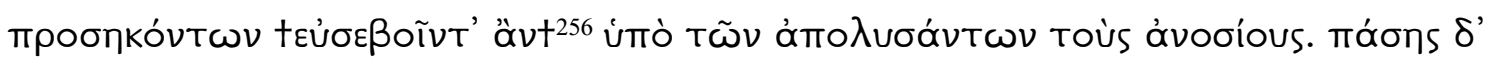

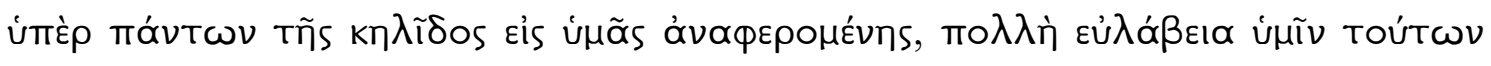

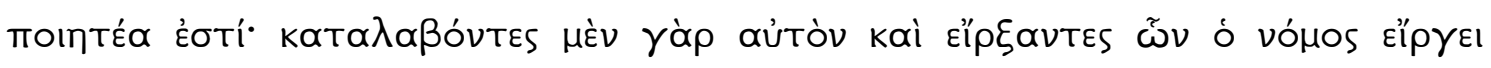

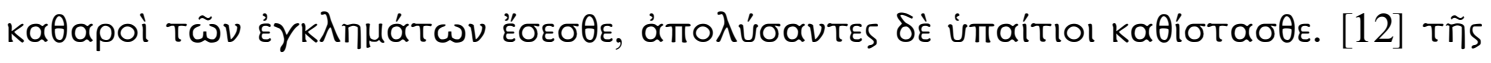

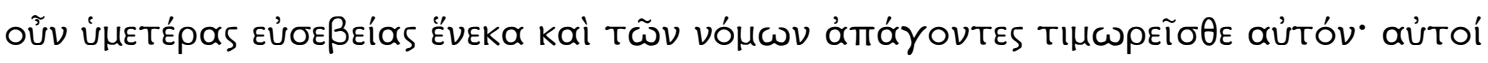

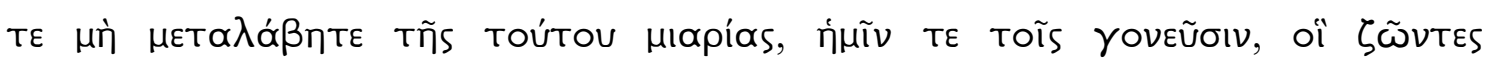

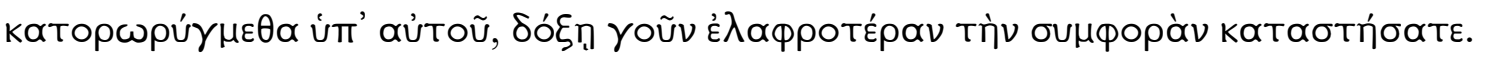

\section{3}

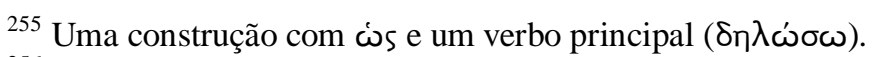

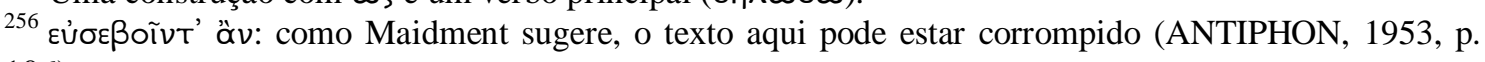
106).
} 
[1] Que a própria necessidade ${ }^{257}$ obriga a todos a falar e a agir contra a sua

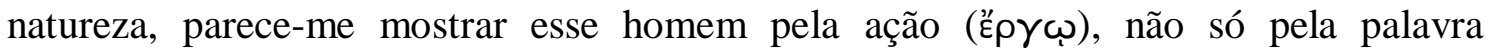
( $\lambda$ ó $(\omega)$. Pois enquanto no passado ele não era nada insolente e atrevido, agora, pela própria desgraça, é obrigado a dizer coisas que eu não pensei que ele diria em algum momento. [2] Eu, dando prova de grande estupidez, não imaginei que ele replicaria; caso contrário não teria me privado da metade da minha acusação pronunciando um só discurso ( $\lambda$ óyov) ao invés de dois. Ele, por outro lado, se não fosse tão atrevido, não teria dupla vantagem sobre mim: ao ter oferecido um discurso de defesa contra um discurso meu e ao fazer sem risco de réplica as acusações que ele pronunciou ${ }^{258}$. [3] Ao ter tal vantagem sobre nós em seus discursos e, muito mais do que neles, nas ações que realizou, impiamente pede a vocês que aceitem integralmente ${ }^{259}$ sua defesa. Eu, por outro lado, não tendo cometido mal algum, mas tendo sofrido coisas miseráveis e terríveis, e agora sofrendo ainda as mais terríveis delas pela ação ( palavra $(\lambda o ́ \gamma \omega)$, buscando refúgio em sua piedade ${ }^{260}$, apelo a vocês, juízes, vingadores das ações ímpias e discriminadores ${ }^{261}$ das piedosas, que, quando os fatos são claros, não sejam persuadidos pela perversa sutileza (ákpıßzías) dos discursos ${ }^{262}$ a julgar falsa a verdade das ações realizadas. [4] Pois enquanto a sutileza (ớkpíßєıа) é mais persuasiva que verídica ${ }^{263}$, a verdade ( $\alpha \dot{\alpha} \lambda \hat{\theta} \theta \varepsilon ı$ ) será pronunciada com menos engano, mas também com menor eficácia persuasiva ${ }^{264}$. Portanto, confiando na justiça, desdenho o discurso da defesa; mas desconfiando da inflexibilidade da divindade (тoũ Saímovos), temo que não somente seja privado do proveito de meu filho, como também que eu o veja sendo condenado por vocês como um suicida ${ }^{265}$.

[5] Meu oponente chega a tal nível de atrevimento e falta de vergonha que declara, por um lado, que aquele que lançou e matou, nem feriu nem matou, e por outro,

\footnotetext{
${ }^{257}$ Outra personificação de um substantivo abstrato.

${ }^{258} \mathrm{O}$ primeiro discurso da defesa acabou se transformando em um discurso de acusação contra o garoto, ao acusá-lo de ser o responsável pela própria morte.

${ }^{259}$ б $\cup \chi \nu \tilde{\omega}$ s: seria uma forma adverbial rara. É comum o uso da forma neutra.

${ }^{260}$ A acusação repete as palavras usadas pela defesa em 3.2.2.

${ }^{261} \delta 1 \alpha \gamma \nu \omega ́ \mu о \nu \varepsilon s:$ palavra bastante rara.

${ }^{262}$ Decleva-Caizzi nota que, diferentemente do que ocorreu no primeiro discurso da defesa, aqui se

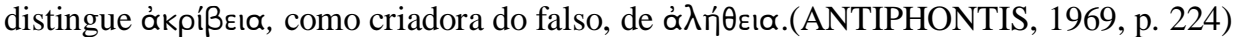

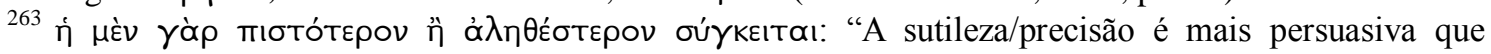

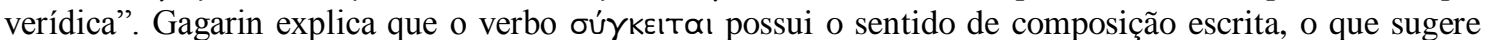
que a sutileza é característica de argumentos escritos (ANTIPHON, 1997, p. 154). Cf. Tucídides, Hist. I, 22.

${ }^{264} \lambda \varepsilon \chi \theta$

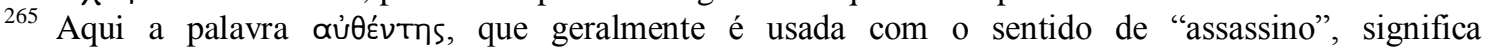
provavelmente "suicida" ou "assassino de si mesmo".
} 
que aquele que nem tocou a lança nem concebeu lançá-la, cravou o objeto no meio de suas próprias costas, errando todas as regiões e todos os corpos. Penso que, ao acusá-lo de matar intencionalmente, eu estaria sendo mais convincente do que ele, que afirma que o jovem nem lançou nem matou. [6] Pois, enquanto um, que se encarregava de pegar as lanças para os lançadores, ao ser chamado naquele exato momento pelo mestre

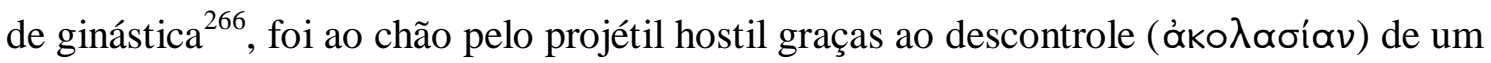
lançador, e morreu miseravelmente, mesmo não errando contra ninguém, o outro, depois de $\operatorname{errar}^{267}$ com relação ao momento exato da ação de recolher a lança, não foi impedido de atingir a área de lançamento, mas lançou em uma área para mim infeliz e dolorosa. Com efeito, é mais certo dizer que o jovem matou intencionalmente mais do que afirmar que não lançou nem matou. [7] Ainda que tenha matado meu filho não menos sem intenção do que com intenção, e negando absolutamente que o matou, ele afirma que sequer é condenado pela lei que proíbe matar justa e injustamente ${ }^{268}$. Mas, então, quem é o lançador? O homicídio se volta contra quem? Contra os espectadores ou contra os escravos pedagogos ${ }^{269}$, os quais ninguém acusa de nada? ${ }^{270}$ Pois, para mim ao menos, a morte de meu filho não é obscura, mas absolutamente clara. E eu afirmo que a lei corretamente declara que os assassinos sejam castigados, pois é justo que o que matou sem intenção sucumba pelos males não-intencionais, e não seria justo que o que foi eliminado ficasse sem vingança porque foi lesado não menos sem intenção do que com intenção. [8] Não é justo que ele seja absolvido por causa do componente de infortúnio de seu erro, pois se o infortúnio não é causado pelo desígnio divino, sendo ele fruto de

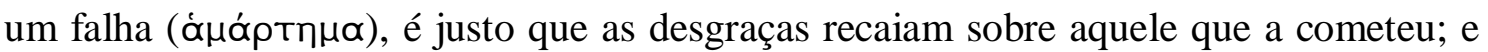
se, ao contrário, a mancha ${ }^{271}$ divina cai sobre o autor por alguma impiedade, não é justo impedir a realização dos ataques divinos.

[9] Disseram também que não é justo que eles, que praticam ações exemplares, sejam merecedores de prejuízos. Mas e nós? Como poderia ser justo sofrermos o que é

\footnotetext{
${ }^{266}$ таıботрі́ßns: uma espécie de treinador ou um mestre de ginástica para jovens que, dentre outras coisas, supervisionaria a prática do lançamento de lanças. Gagarin observa que, em um caso efetivo de tribunal, a figura do mestre de ginástica certamente receberia mais atenção, o que não ocorre aqui (GAGARIN, 1998, p. 35). Cf. Aristóteles, Const. Aten. XLII, 3.

${ }^{267} \pi \lambda \eta \mu \mu \varepsilon \lambda \eta ́$ баs: sinônimo de erro, o verbo significa literalmente "fazer uma nota falsa em música".

${ }^{268}$ Cf. 3.2.9

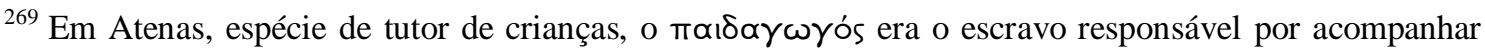
garotos de famílias ricas em suas atividades diárias.

${ }^{270}$ Sequência de perguntas retóricas.

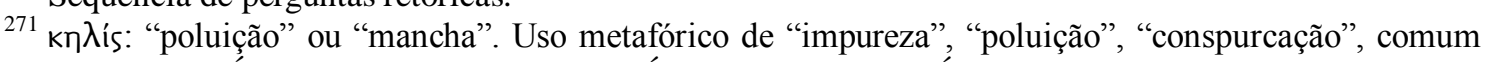
na tragédia. Cf. Ésquilo, Eum. 787; Sófocles, Éd. Rei. 833 e 1384, Éd. Col. 1134.
} 
devido se, mesmo não nos ocupando de coisas menos honestas que as deles, somos

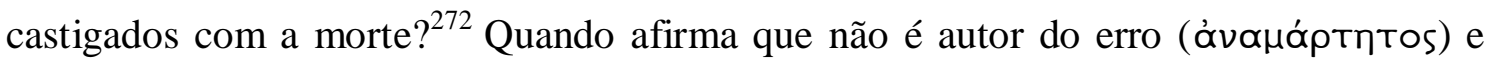
argumenta que as desgraças são dos que erram e que, portanto, não se voltam contra os que não são os seus autores, ele fala em nosso favor, pois o meu filho, sem errar contra alguém e sendo morto pelas mãos desse jovem, seria injustiçado se ficasse sem vingança; e eu, sendo menos autor do erro do que ele, sofrerei coisas terríveis ao não obter de vocês o que a lei me permite. [10] Que o acusado não está absolvido nem do erro nem de matar sem intenção, mas que ambas as coisas devem ser atribuídas aos dois $^{273}$, é o que demonstrarei a partir do que dizem os próprios defensores. Se é justo que o próprio garoto seja o assassino de si mesmo por ter avançado sobre a trajetória da lança ao invés de ter ficado parado sem se mover, tampouco o jovem está livre da culpa, a menos que ele não tenha atirado a lança, mas tenha permanecido imóvel quando meu filho morreu. Sendo o homicídio obra de ambos, enquanto o meu filho foi vingado ao errar contra si mesmo mais severamente do que em comparação ao erro em si, pois está morto, como é justo que o jovem escape impune, tendo ele se tornado cúmplice ${ }^{274} \mathrm{e}$ partícipe do erro contra os que não mereciam? ${ }^{275}$

[11] Haja vista que o jovem é corresponsável pelo homicídio, com base no discurso de defesa dos próprios acusados, vocês não poderiam absolvê-lo de maneira justa e piedosa. Pois, nem nós, os acusadores, destruídos pelo erro desses homens, sofreríamos pelas mãos dos senhores ações pias, mas ímpias, caso fossemos condenados como autores de nossa própria morte; nem tampouco os que nos trazem a morte seriam tratados de modo piedoso por aqueles que absolveram homens ímpios, caso não sejam banidos dos lugares que a eles não convém estar. E, visto que toda a mancha, de quem quer que seja, recairá sobre vocês, é preciso que vocês tomem muito cuidado com esses assuntos. Pois se condenarem o jovem e o banirem dos lugares de onde a lei o bane ficarão livres das acusações, mas se, por outro lado, o absolverem, passarão a ser os responsáveis. [12] Nessas condições, por causa da piedade dos senhores e das leis, punam o jovem afastando-o para longe daqui ${ }^{276}$; não tomem parte vocês mesmos da

\footnotetext{
272 Outra pergunta retórica.

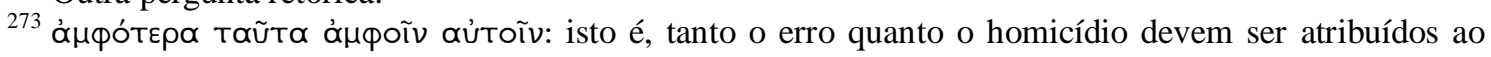
garoto e ao jovem.

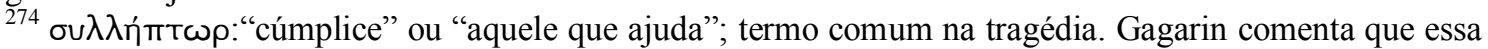
palavra foi usada para fazer referência aos espíritos quase divinos que auxiliavam um homem em um crime (ANTIPHON, 1997, p. 156). Cf. Ésquilo Ag. 1507; Eurípides Or. 1230.

${ }^{275}$ Uma pergunta retórica.

${ }^{276}$ Isto é, para o exílio.
} 
impureza deste aí; e para nós, os pais, que por causa dele estamos enterrados ainda que $\operatorname{vivos}^{277}$, tornem a desgraça mais tolerável ao menos em aparência.

\section{$3.4^{278}$}

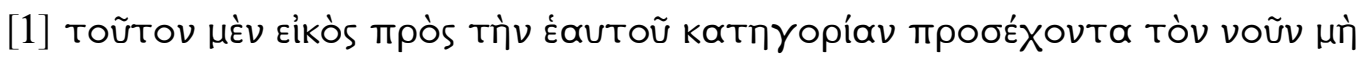

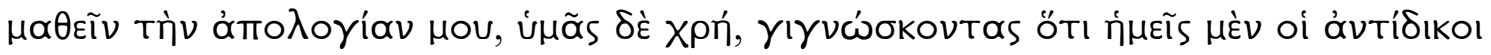

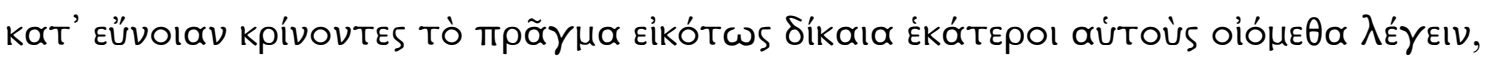

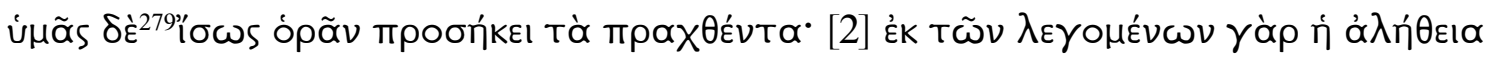

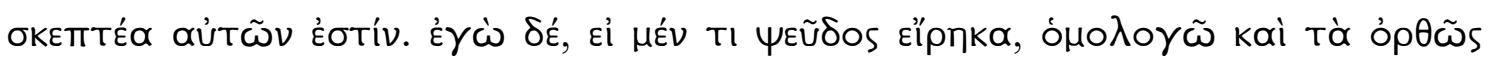

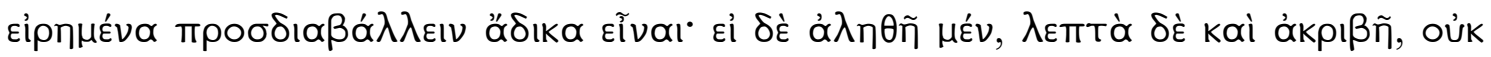

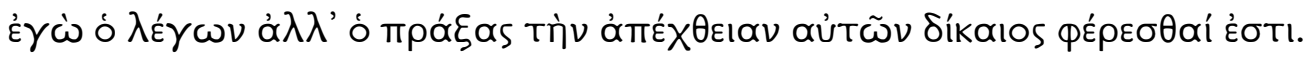

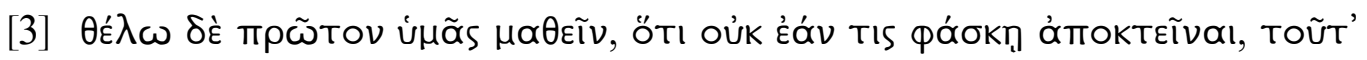

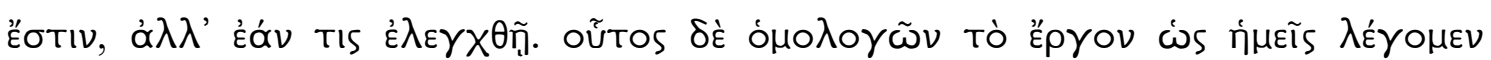

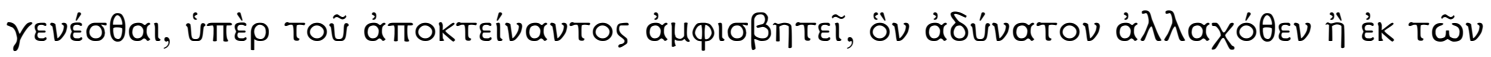

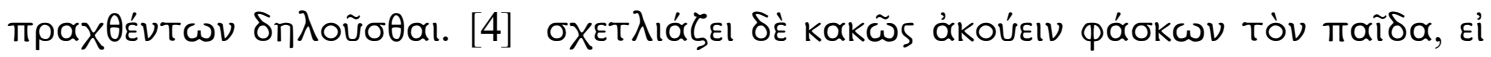

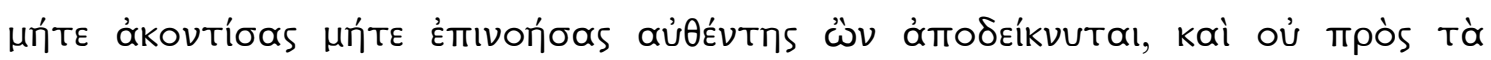

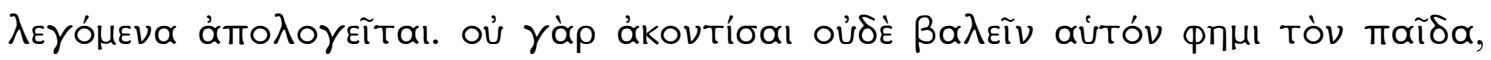

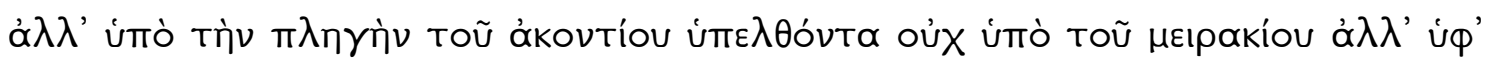

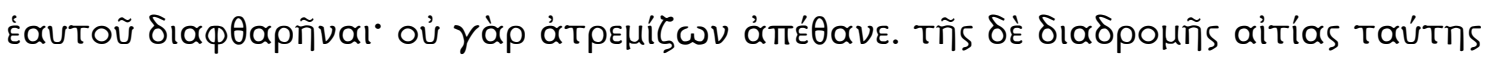

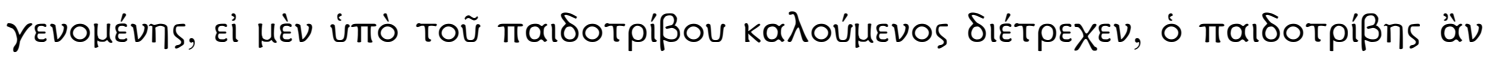

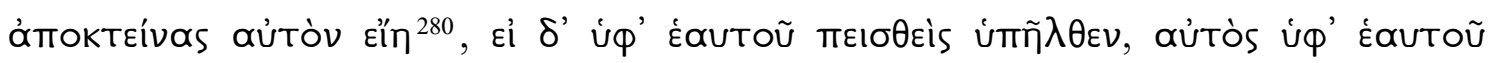

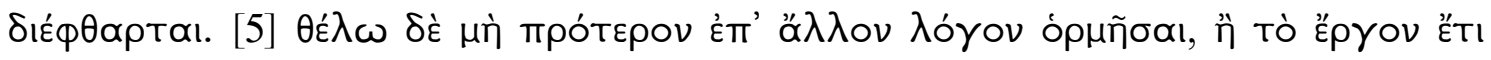

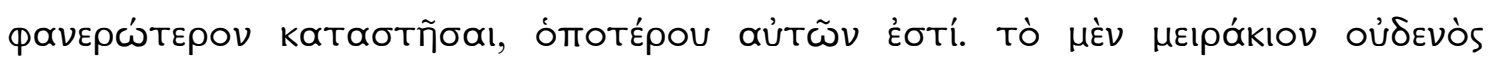

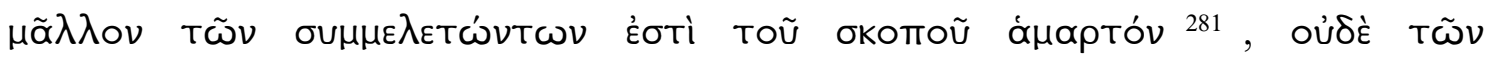

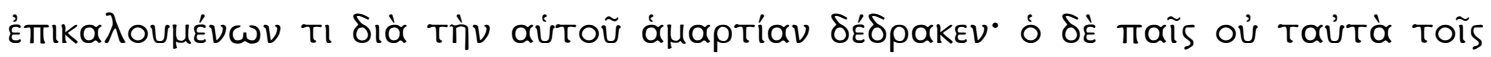

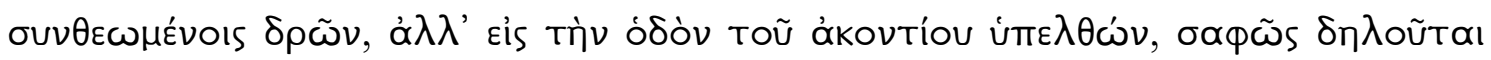

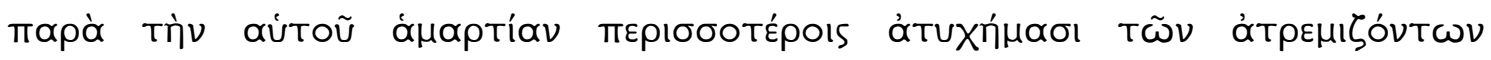

\footnotetext{
${ }^{277}$ Cf. nota em 3.2.10

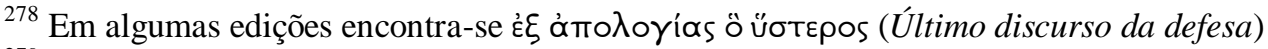

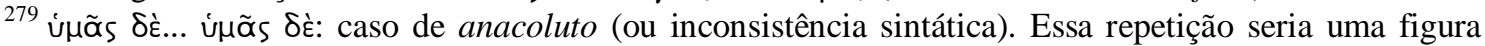
retórica comum e, aqui, talvez exista uma intenção por parte da defesa de confundir os juízes.

${ }^{280}$ Construção perifrástica: ámokтé́vas ... Eïn. A perífrase com particípio aoristo seria rara. cf. 2.3.8

${ }^{281}$ Construção perifrástica: غ̇oтì ... áuapтóv. Outro caso raro de perífrase com particípio aoristo. Cf. 3.4.4
} 


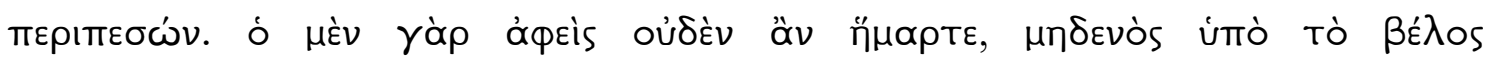

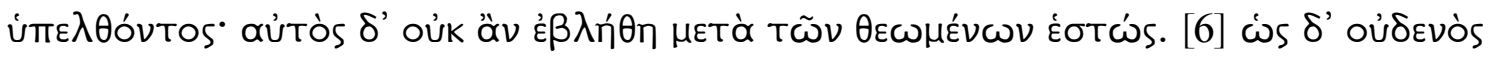

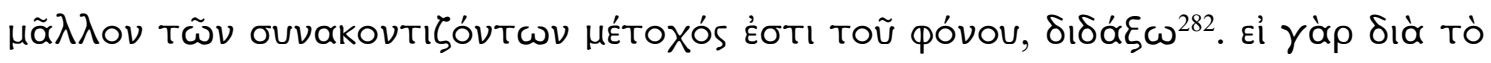

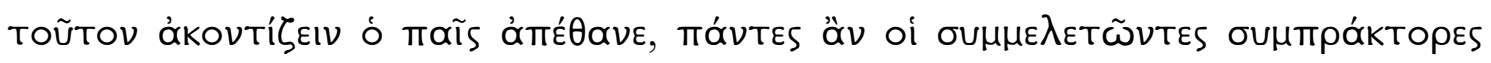

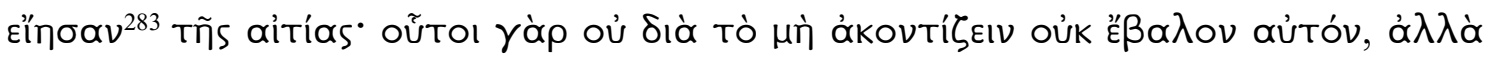

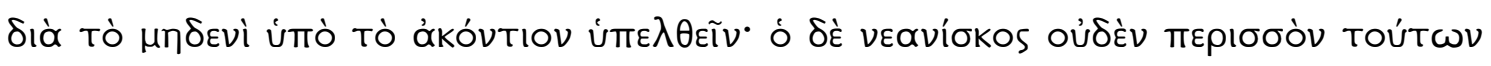

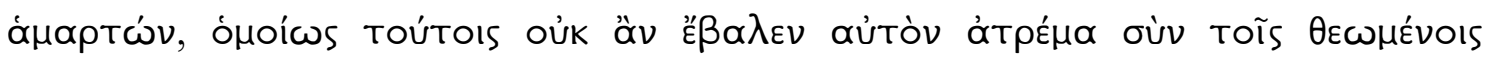

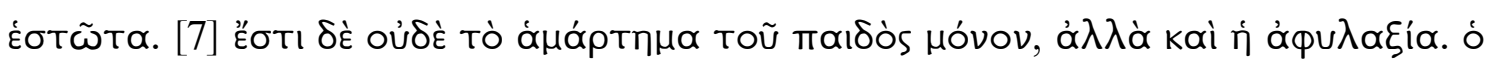

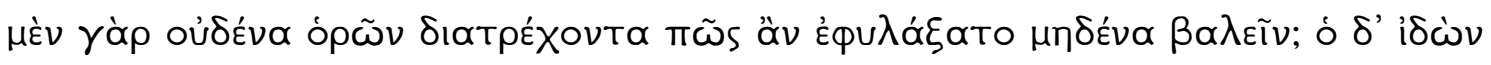

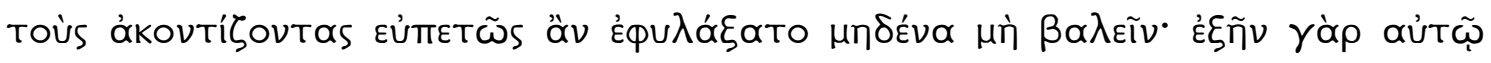

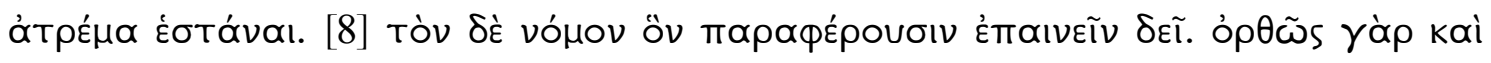

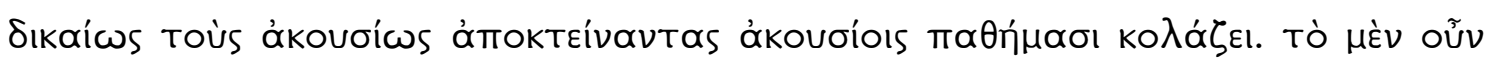

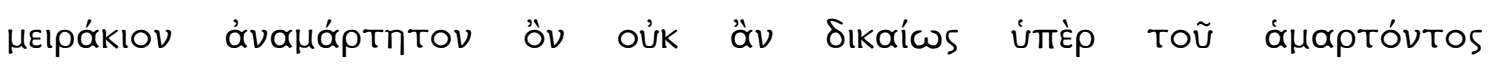

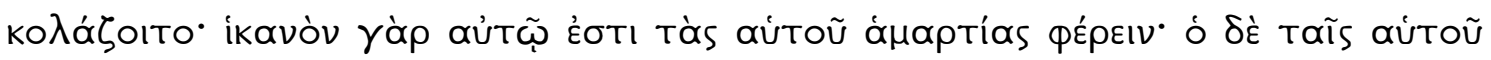

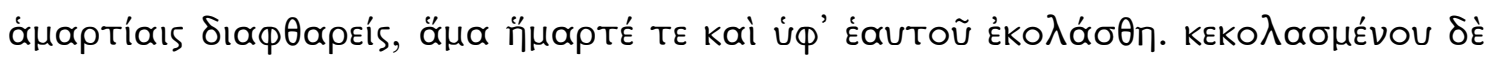

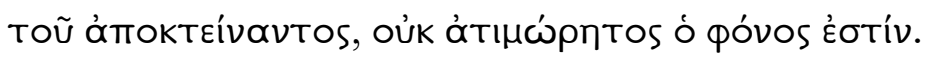

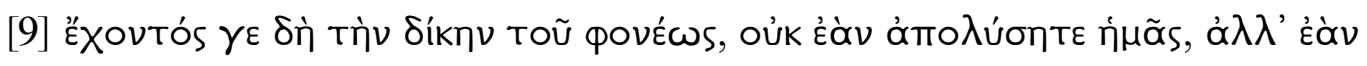

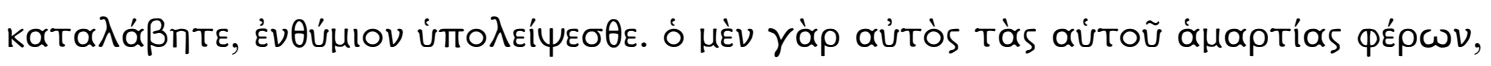

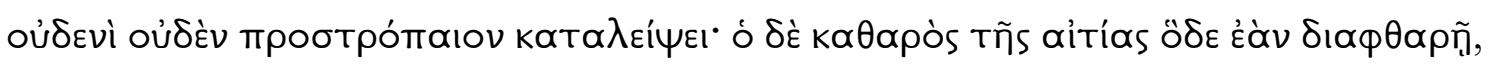

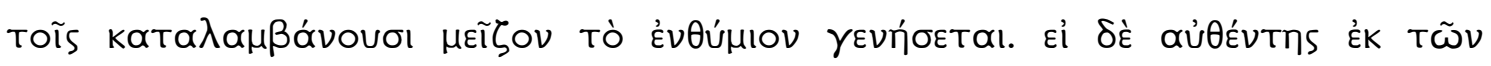

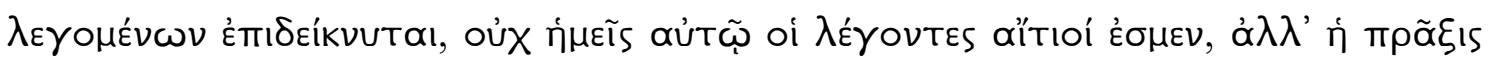

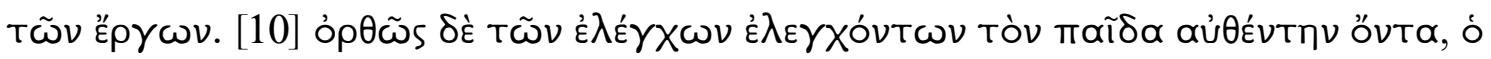

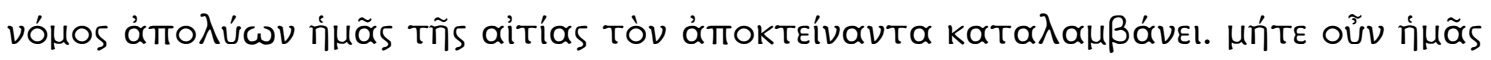

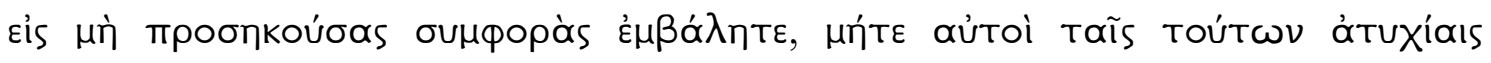

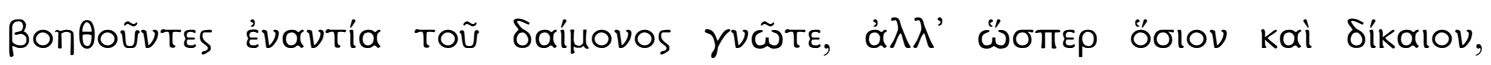

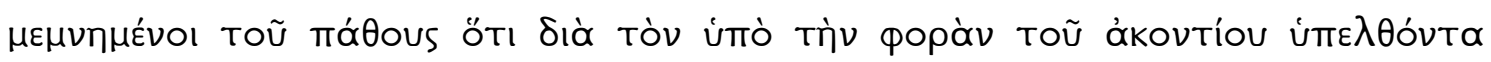

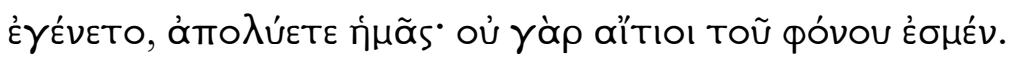

\section{4}

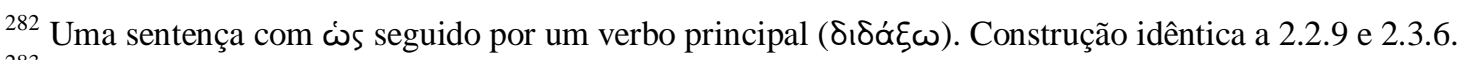

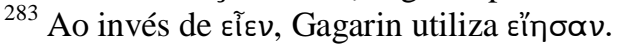


[1] Era natural (Eikós) ${ }^{284}$ que meu adversário, detendo-se em sua própria acusação, não tivesse entendido meu discurso de defesa; mas convém a vocês, compreendendo que nós oponentes, ao julgarmos o assunto de modo favorável a nós

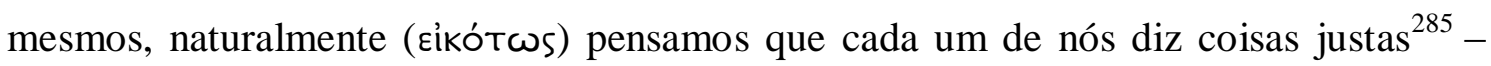
convém a vocês, repito, observar de modo equânime as ações realizadas, [2] pois a verdade das ações deve ser examinada a partir do que se diz. Eu, de minha parte, se tenho dito alguma mentira, concordo que também as coisas ditas corretamente ${ }^{286}$ podem ser desacreditadas como sendo injustas; mas, se tenho dito a verdade, mesmo com sutileza ${ }^{287}$ e precisão, não é justo que eu, que falo, mas sim o autor das ações, carregue o ódio dos argumentos da acusação.

[3] Em primeiro lugar, quero que vocês entendam que um homem não é o assassino se alguém declarar que ele matou, mas se alguém encontrar uma prova. Nosso oponente, estando de acordo com o fato de que a ação ocorreu como nós estamos dizendo, discorda com relação ao assassino, que é impossível ser indicado de outro modo que a partir dos fatos. [4] Ele ainda se queixa de ouvir que o filho está sendo caluniado se é declarado assassino de si mesmo quando não atirou a lança nem pensou em fazê-lo, mas não se defende contra as coisas ditas. Pois não afirmo que o garoto lançou nem acertou ele mesmo, mas que ao avançar sobre a área de lançamento da lança foi morto não pelo jovem, mas por ele mesmo, pois não morreu estando imóvel. $\mathrm{E}$ porque esse avanço sobre a área de lançamento foi o responsável, se tivesse corrido de um lado para o outro ao ser chamado pelo mestre de ginástica, este teria sido seu assassino; mas se avançou tendo sido estimulado por si mesmo, a si mesmo destruiu. [5] Não quero me precipitar sobre outro argumento ( $\lambda$ óyos) antes de estabelecer ainda mais

\footnotetext{
${ }^{284} \mathrm{Na}$ Tetralogia II, o Eikós não tem a mesma importância que na Tetralogia I, pois o argumento do zíkós normalmente é empregado em uma situação em que um fato está em disputa. Nessa passagem, a palavra sugere "inclinação natural de uma pessoa". Aqui, pode ser usado com o sentido mais abrangente de "é natural" ou "era de esperar".

${ }^{285}$ Gagarin ressalta essa declaração sincera das intenções de cada litigante ao considerarem o seu discurso como o mais justo. Mas provavelmente essa declaração franca, segundo ele, não caberia em um caso efetivamente apresentado em um tribunal (ANTIPHON, 1997, pp. 157-58).

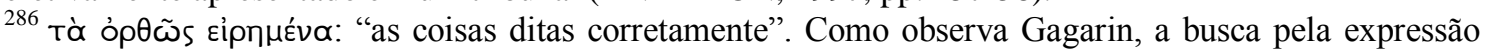

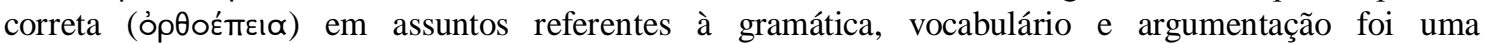
preocupação importante de Protágoras e outros pensadores do século V a.C. denominados sofistas

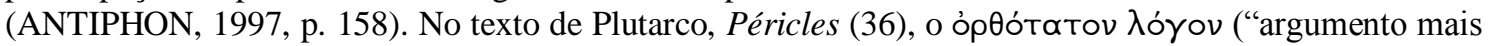
correto") é justamente o que Protágoras e Péricles buscam em uma discussão.

${ }^{287} \lambda_{\varepsilon \pi T}$ Tós: "sutil”; assim como ókpıßńs, "preciso", seria um termo importante da discussão do século $\mathrm{V}$ a.C.
} 


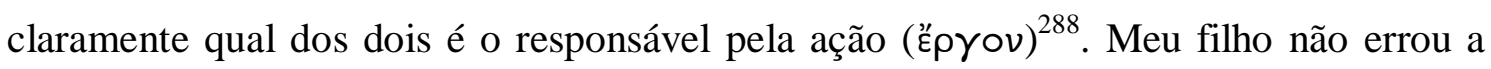
área de lançamento mais do que seus companheiros de exercício e não realizou por seu próprio erro alguma das coisas de que é acusado. O garoto, por outro lado, não fazendo as mesmas coisas que os outros espectadores, mas tendo avançado no trajeto da lança, mostra claramente que, por seu próprio erro, encontrou infortúnios muito superiores que aos dos que ficaram imóveis. O lançador, mesmo se tivesse lançado, não teria errado se ninguém tivesse avançado sob o alcance do projétil; o garoto, por outro lado, não teria sido atingido, se tivesse ficado no meio dos espectadores. [6] Que meu filho não é corresponsável pelo homicídio mais do que os que com ele lançavam, é o que demonstrarei. Pois se o garoto morreu por causa do lançamento do meu filho, todos os seus companheiros de exercício compartilhariam da responsabilidade, pois eles não o atingiram não por não lançarem, mas por ninguém ter avançado sob o alcance de suas lanças. O meu jovem filho, não cometendo falta muito maior do que as daqueles, de modo semelhante àqueles não teria atingido o garoto se este tivesse ficado imóvel com os espectadores. [7] Além disso, não há somente a falha por parte do garoto, mas também a negligência ${ }^{289}$. Pois, um, não vendo alguém correndo de um lado para o outro, como teria se precavido para não acertar alguém $?^{290} \mathrm{O}$ outro, tendo visto os lançadores, teria facilmente se precavido para que ninguém o atingisse, pois ele poderia ter ficado imóvel. [8] E mais, deve-se louvar a lei que eles mencionam ${ }^{291}$, pois de maneira correta e justa pune com sofrimentos não-intencionais os que matam de modo não-intencional. O jovem, portanto, não sendo o autor do erro, não poderia ser punido de modo justo em nome daquele que o cometeu, pois cabe a este carregar o próprio erro. $\mathrm{O}$ garoto, por sua vez, tendo sido morto pelos próprios erros, ao mesmo tempo errou e por si próprio foi punido. Tendo-se punido o assassino, o homicídio não fica sem vingança.

[9] Tendo já o assassino a justiça, se vocês não nos absolverem, mas nos

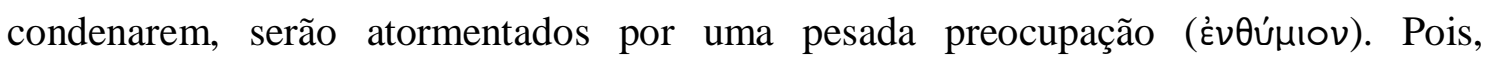
enquanto o garoto, carregando o próprio erro, não deixará para ninguém o seu espírito

\footnotetext{
${ }^{288}$ Esse parece ser o assunto da Tetralogia II.

289 á $q u \lambda \alpha \xi i ́ \alpha$ : "falta de precaução", "imprudência", "descuido". Palavra rara, que talvez tenha sido

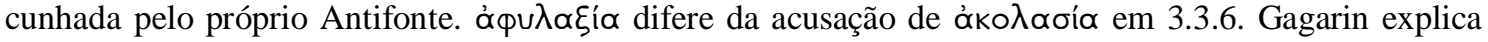

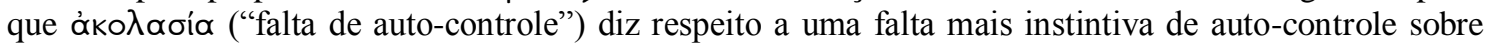

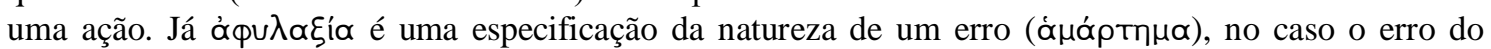
garoto em ser negligente ao recolher a lança em um momento inoportuno. (ANTIPHON, 1997, p. 159) ${ }^{290}$ Pergunta retórica.

${ }^{291}$ A lei que proíbe matar justa e injustamente, foi, na verdade, mencionada inicialmente pela própria defesa em 3.2.9.
} 
vingativo (тробтро́тঞıоv), о jovem, livre da culpa, deixará para os seus acusadores,

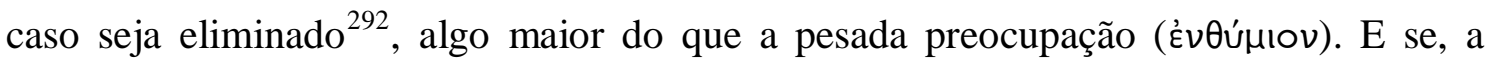
partir das coisas ditas, o garoto é indicado como assassino de si mesmo, nós, que falamos, não somos os responsáveis por essa falha, mas o andamento dos acontecimentos $^{293}$. [10] Uma vez que as provas confirmam corretamente que o garoto é o assassino de si mesmo, a lei ${ }^{294}$, absolvendo-nos da culpa, condena o assassino. Enfim, não lancem contra nós desgraças que não são nossas, nem emitam um veredito contrário à divindade (тoũ Saímovos), ao saírem no auxílio dos infortúnios dos acusadores, mas, antes, como é piedoso e justo, nos absolvam, lembrando-se do sofrimento que se deu quando o garoto avançou sobre a trajetória da lança. Pois não somos os responsáveis pelo homicídio ${ }^{295}$.

\subsection{Texto, tradução e notas da Tetralogia III [4]}

\section{$4.1^{296}$}

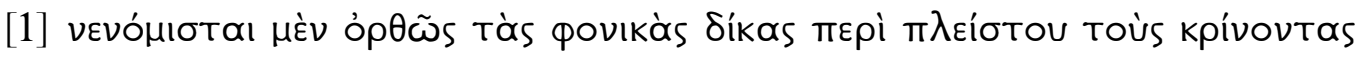

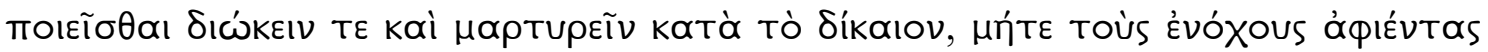

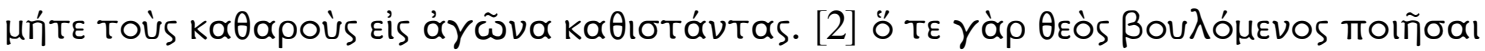

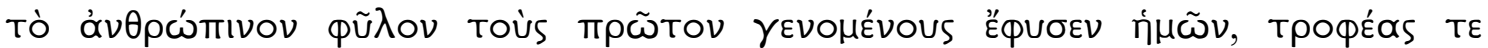

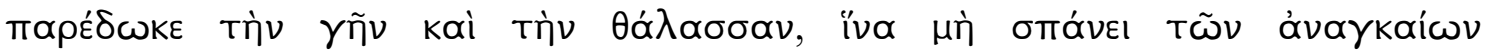

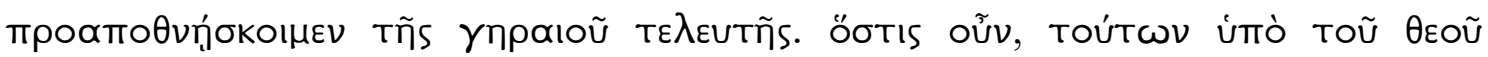

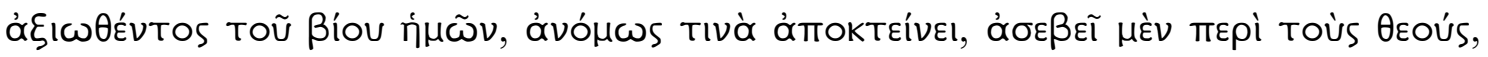

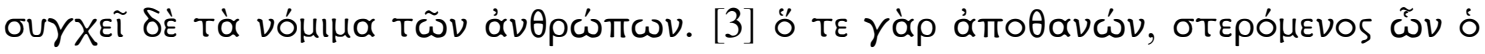

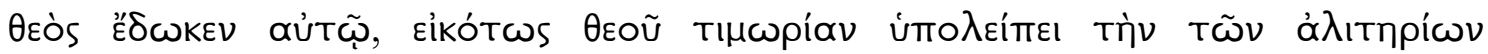

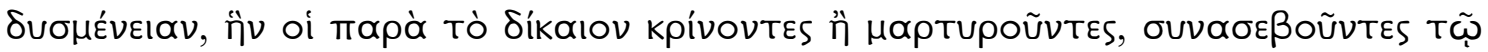

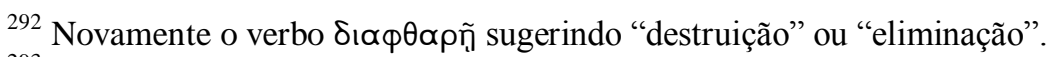

293 Outra personificação.

${ }^{294}$ Provavelmente a lei referida em 3.4.8.

295 Novamente, indica-se o motivo principal de toda a Tetralogia II.

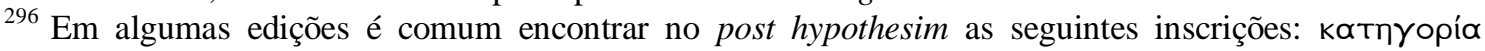

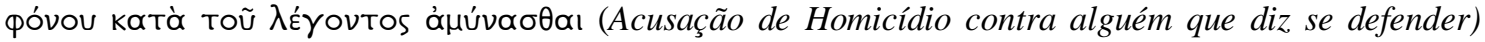

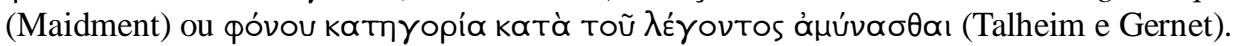




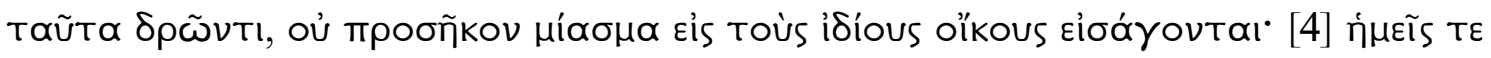

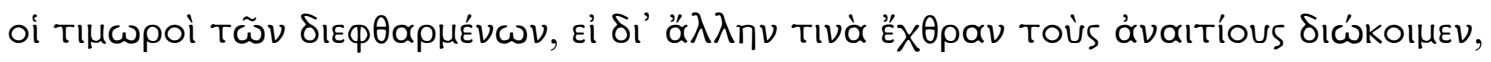

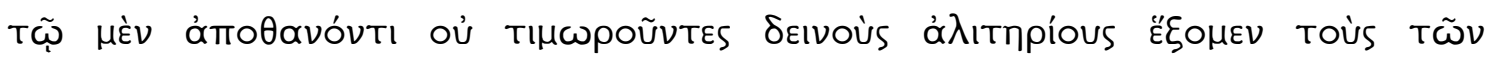

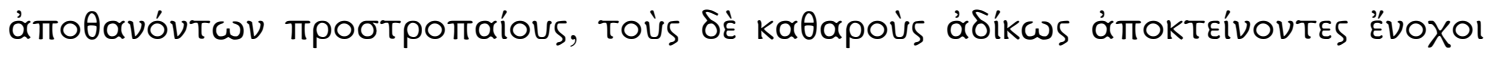

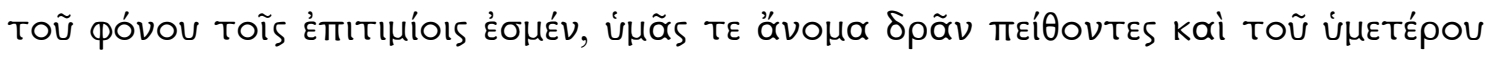

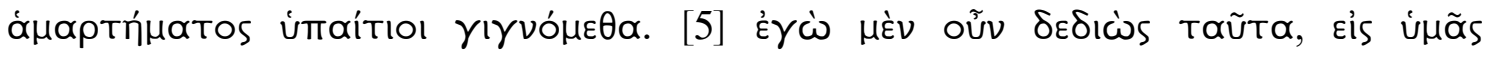

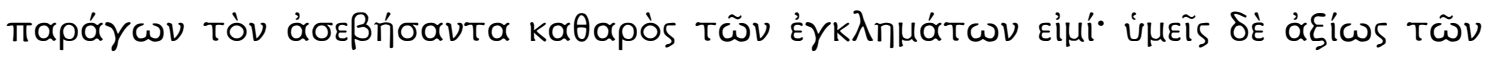

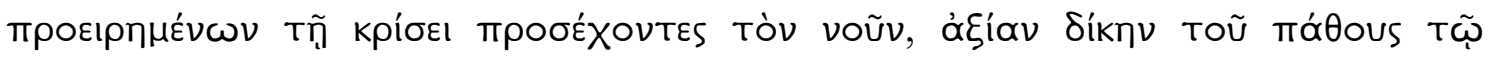

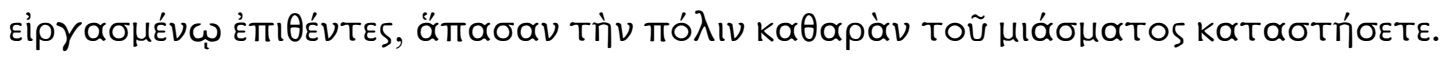

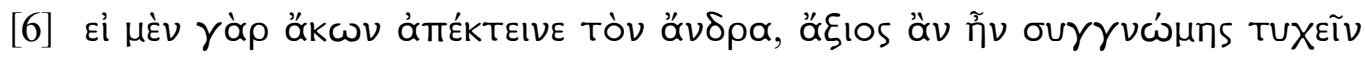

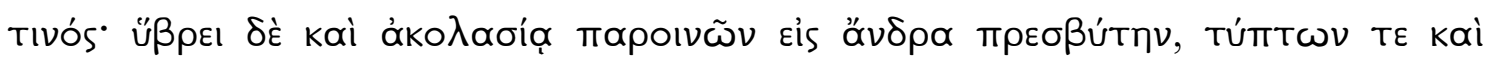

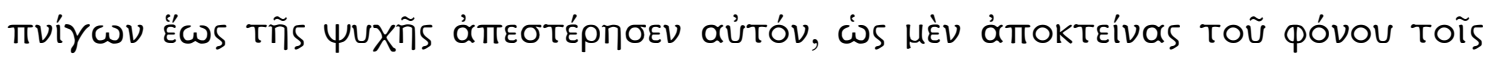

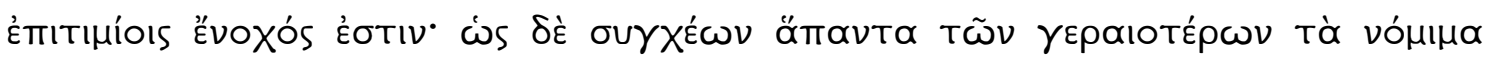

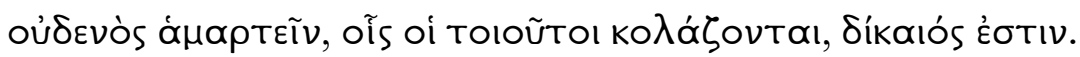

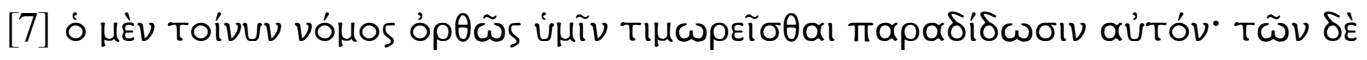

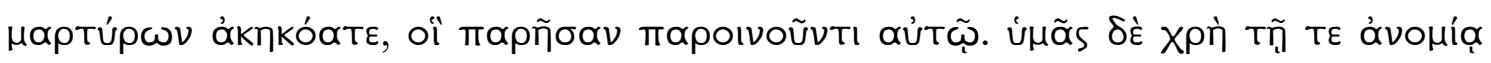

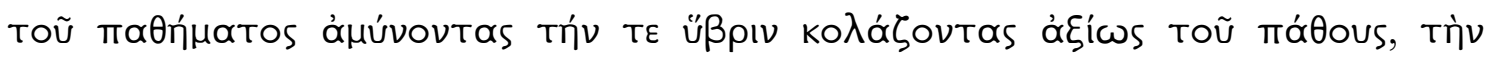

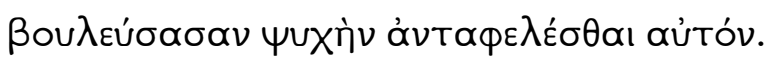

\section{1}

[1] É uma norma corretamente estabelecida ${ }^{297}$ que, nos casos de homicídio, os acusadores $^{298}$ se esforcem bastante para fazer a acusação e testemunhar segundo a justiça, não deixando escapar os responsáveis ${ }^{299}$, nem levando os inocentes ao tribunal.

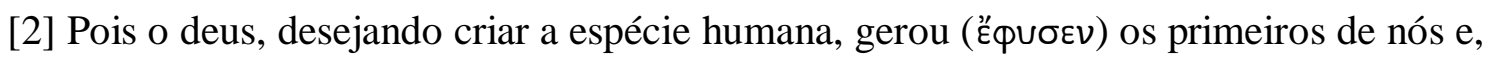
como alimento, nos deu a terra e o mar para que não morrêssemos antes pela falta das coisas necessárias do que pelo fim oriundo da velhice. Uma vez, então, que a nossa vida

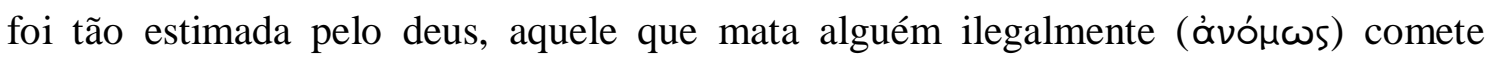

\footnotetext{
${ }^{297}$ Ou seja, o que é estabelecido pelo vónos (pela "lei" e pelo "costume").

${ }^{298}$ Gernet, Decleva-Caizzi e Morrison traduzem toùs kpívovtas por "juízes" ou "júri”; Gagarin e Maidment, por "acusadores". Para Gagarin, embora a palavra possa designar "juízes" e "júri”, o resto da sentença sugere que toùs kpívovtas sejam os acusadores (ANTIPHON, 1997, p. 163).

${ }^{299}$ Toùs Ėvóxous: termo jurídico comum.
} 
impiedade contra os deuses e viola as normas (vó $\mu \mu \propto)^{300}$ estabelecidas pelos homens. [3] Pois, ao ser privado das coisas que a divindade lhe deu, o morto naturalmente

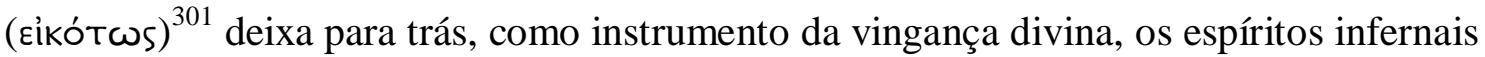
hostis $^{302}$; os que acusam e também os que testemunham contrariamente ao justo, por serem cúmplices da impiedade do assassino, levam para dentro de suas próprias casas tais espíritos, ainda que o miasma não lhes pertença. [4] Se nós, os vingadores dos mortos, perseguimos os inocentes por causa de algum outro ressentimento, não vingando o morto, não apenas suscitaremos contra nós mesmos os terríveis espíritos infernais, os espíritos coléricos dos mortos, como também estamos sujeitos às penas ${ }^{303}$ do homicídio se injustamente condenamos à morte os inocentes. E mais, nós também nos tornamos responsáveis pelos seus erros, juízes, se lhes persuadimos a realizar coisas ilegais. [5] Eu, portanto, temendo essas coisas, estou livre das acusações ${ }^{304}$ ao trazer o homem ímpio até vocês. Vocês, por outro lado, atentando-se de modo digno para o veredito das coisas que já foram ditas, se aplicarem ao criminoso uma pena justa pelo sofrimento causado, deixarão toda a cidade livre das impurezas ( $\mu$ ı́ó $\sigma \mu \alpha \tau o \varsigma)$.

[6] Pois bem, se o réu tivesse matado o homem de modo não-intencional (ớk $\omega v$ ), seria merecido que recebesse alguma comiseração. Mas, embriagado, por soberbia

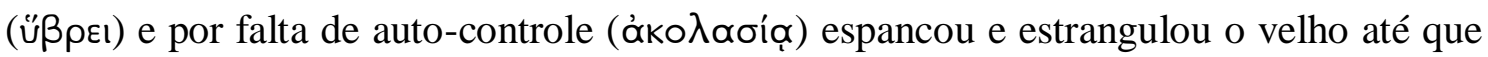
lhe privasse da vida; como autor do homicídio ele está sujeito às penas, como violador de todas as normas (vómıนa) segundo as quais não se deve errar contra os velhos ${ }^{305}$, merece ser punido com as penas correspondentes a tais violações.

[7] A lei (vónos) ${ }^{306}$, portanto, corretamente permite que vocês o castiguem. Além do mais, vocês ouviram as testemunhas ${ }^{307}$, que estavam com o réu quando ele estava

\footnotetext{
${ }^{300}$ Mais amplo que vómos, o termo tò vó práticas e as crenças dos homens.

${ }^{301}$ Diferentemente do uso na Tetralogia I, aqui o argumento do દíkós não desempenhará uma função tão relevante no discurso.

${ }^{302}$ De acordo com Gagarin, o termo á $\lambda ı$ เńpıos com o sentido de “espíritos vingadores" seria bastante raro e ocorreria só nessa Tetralogia III (4.1.3; 4.1.4; 4.2.8; 4.4.10) (ANTIPHON, 1997, p. 163).

${ }^{303}$ Nesta passagem, a palavra Ěvoxol, cujo sentido comum seria "responsáveis" ou "culpados", junto com тоĩs દ́тıтıนíoıs adquire um sentido de "penalidades" ou "penas".

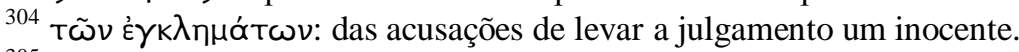

${ }^{305}$ Não haveria uma lei específica acerca de maus tratos contra idosos, mas sim contra alguém que maltratasse seus pais.

${ }^{306}$ Tudo indica que se trata da lei geral mencionada em 4.1.1

${ }^{307}$ Ambos os litigantes mencionam as testemunhas (cf. 4.1.3, 4.4.3, 4.4.8), mas tudo indica que Antifonte está mais interessado nos argumentos. Isso explicaria a omissão por parte do autor da presença do testemunho nas Tetralogias.
} 
bêbado. É necessário, pois, que vocês, repelindo a ilegalidade (ơvouríạ) dessa injúria ${ }^{308}$ e punindo merecidamente a desmedida do sofrimento causado por ele, suprimam completamente a vida daquele que deliberou tal crime.

\section{$4.2^{309}$}

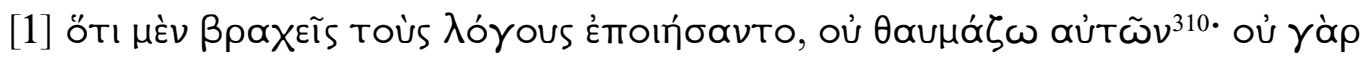

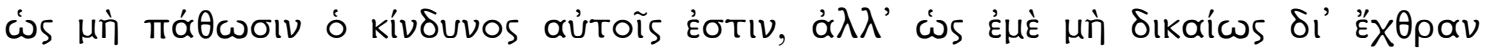

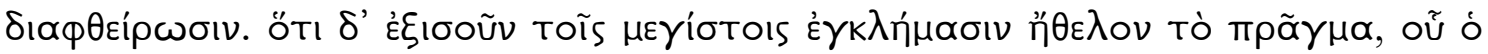

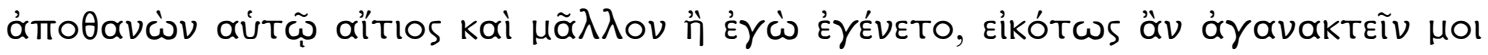

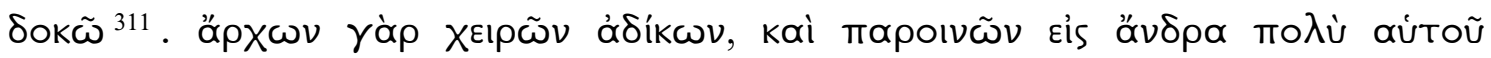

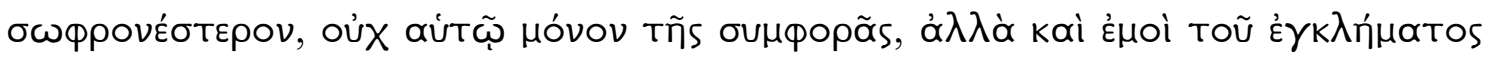
aÍTIOS YÉYOVEv.

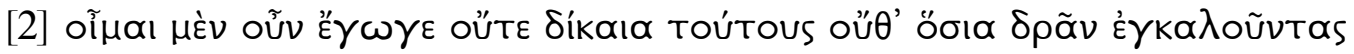

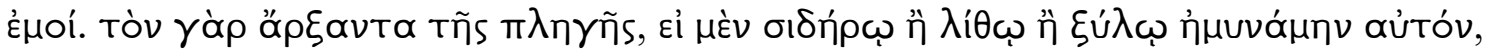

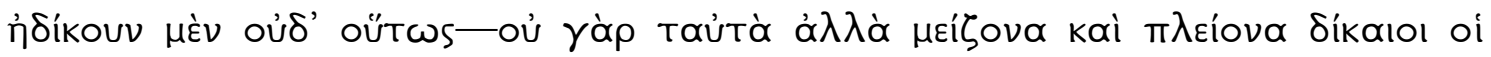

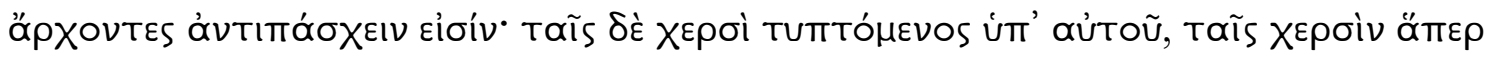

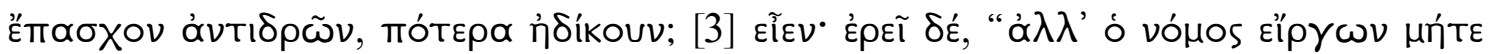

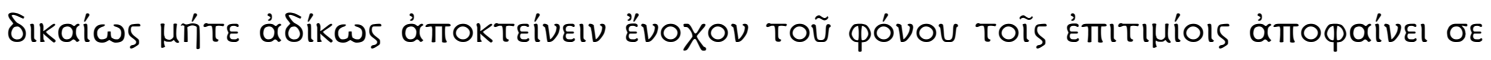

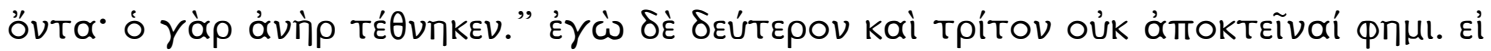

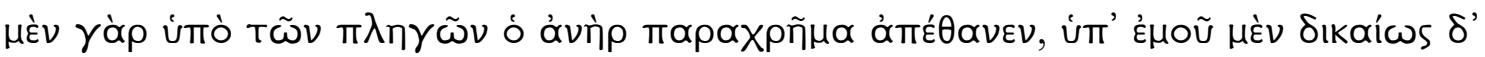

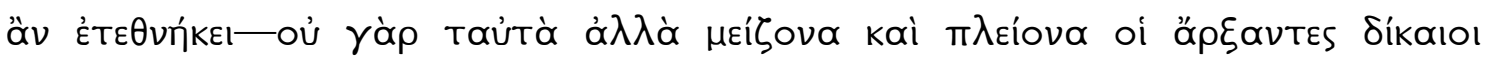

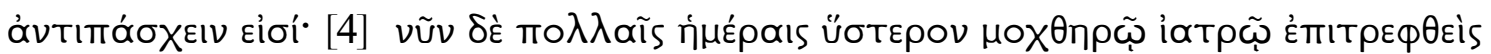

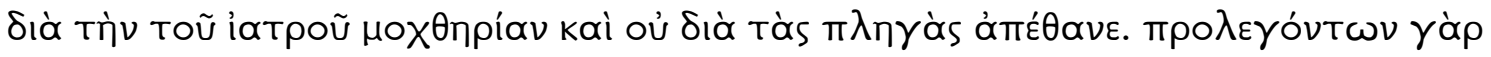

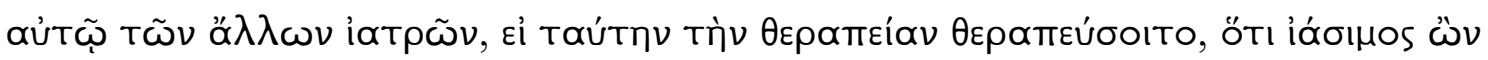

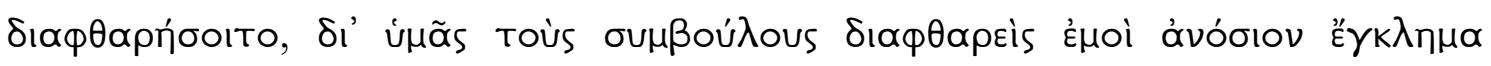

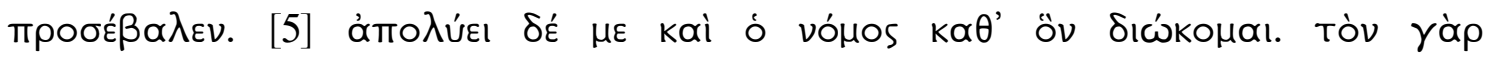

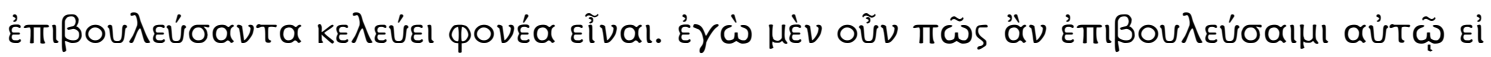

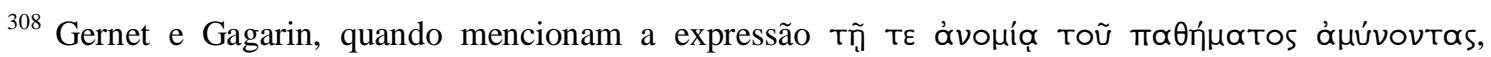
traduzido aqui como "ao repelirem a ilegalidade dessa injúria", falam do costume da poesia grega de dar aos termos abstratos o valor de palavras concretas. (GERNET, 1954, p. 90; ANTIPHON, 1997, p. 165)

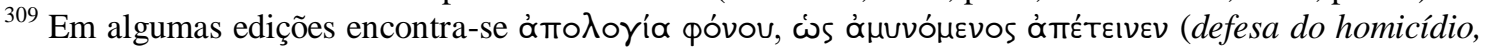
segundo a tese de que o jovem assassinou em defesa própria)

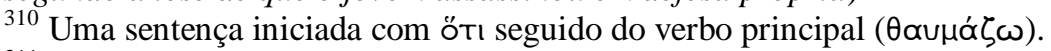

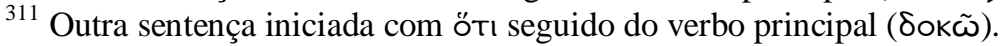




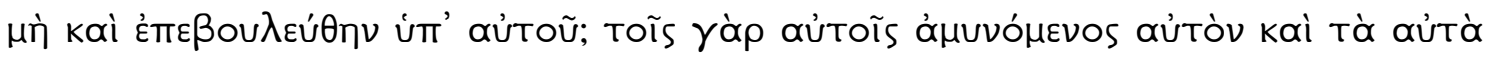

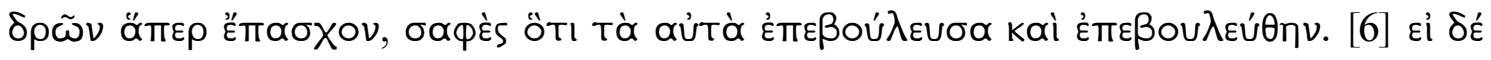

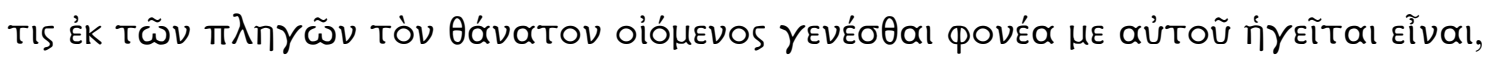

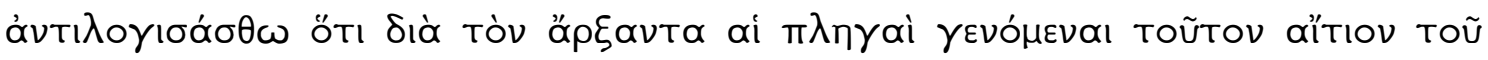

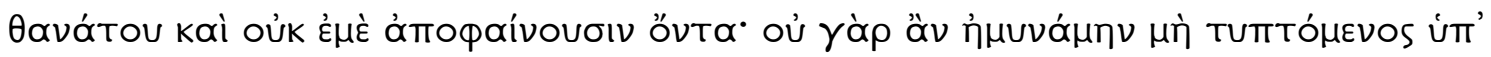

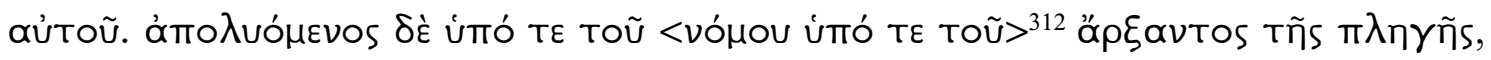

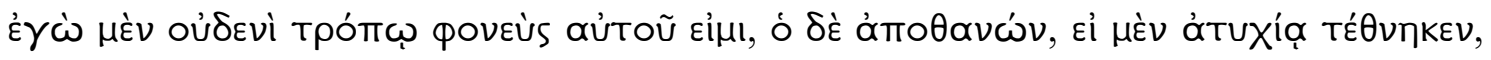

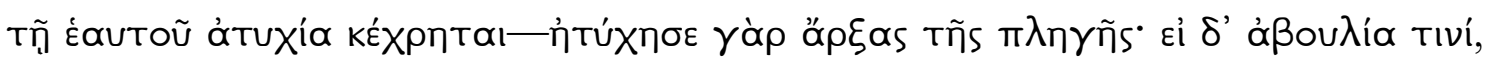

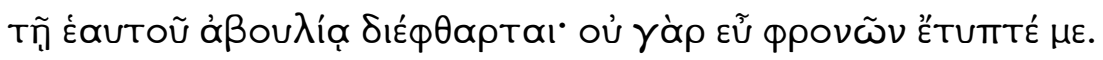

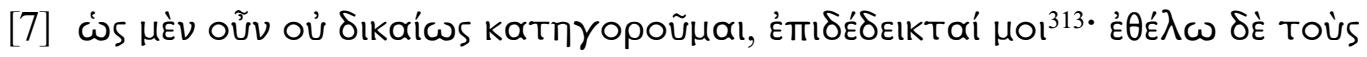

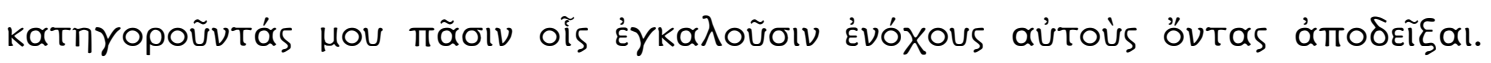

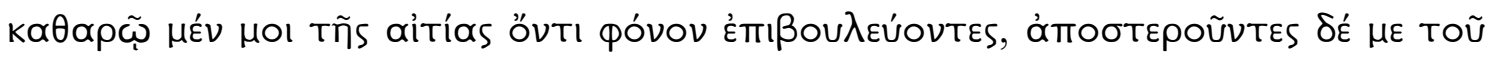

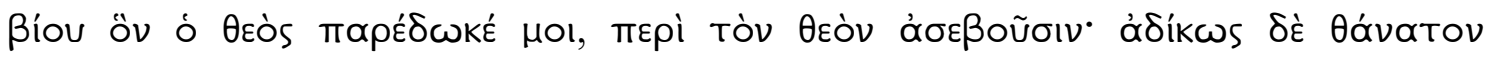

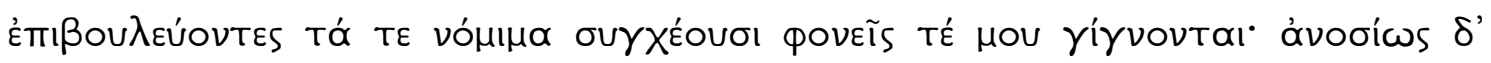

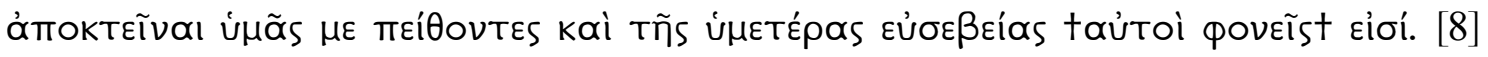

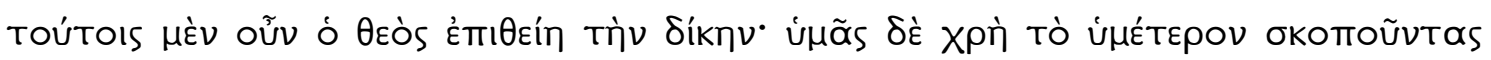

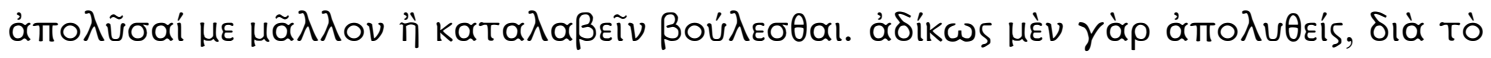

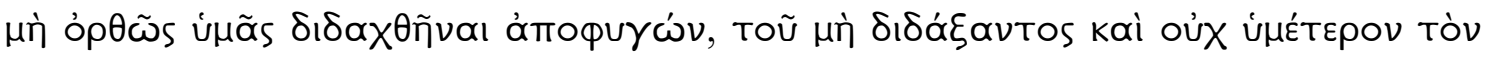

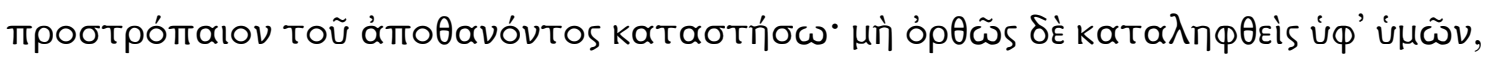

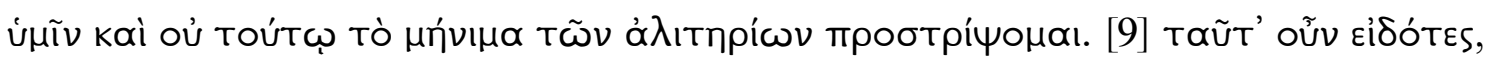

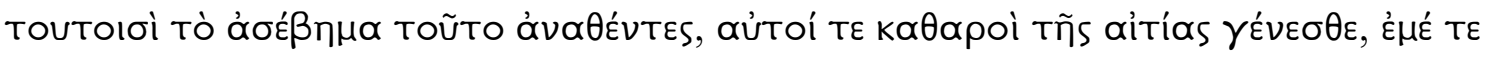

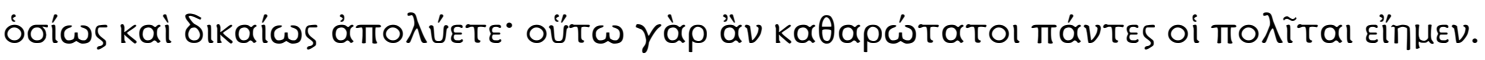

\section{2}

[1] Que eles tenham feito um discurso breve, não me deixa surpreso, pois de fato o risco não é que eles sofram algum mal, mas que, por causa de seu ressentimento, me levem injustamente à morte. Por outro lado, que pretenderam equiparar às mais graves acusações esse caso em que o morto, mais do que eu, foi o próprio responsável, leva-me

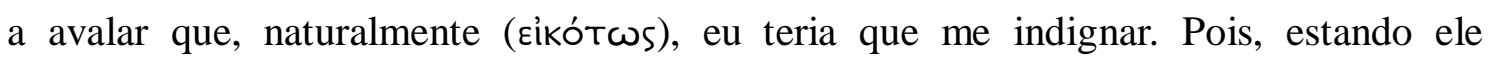

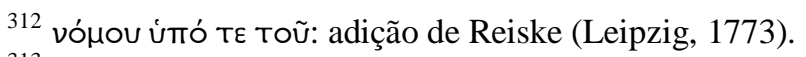

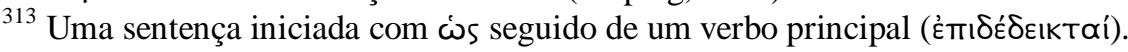


embriagado e começando uma luta injustificada contra um homem muito mais sensato do que ele, não apenas se tornou o responsável por sua própria desgraça como também pela acusação que recai sobre mim.

[2] Eu mesmo, com efeito, penso que esses homens não fazem nem coisas justas nem piedosas ao lançarem sobre mim essa acusação, pois ainda que eu tivesse me defendido daquele que começou a agressão com um ferro ou uma pedra ou um pau ${ }^{314}$, nem assim eu teria procedido ilegalmente - pois os que começam a agressão são merecedores de sofrer em troca não só esse castigo, mas maiores e mais em umerosos ${ }^{315}$. Se fui atingido por suas mãos e com as mãos lhe devolvi aquilo que eu havia recebido, qual dos dois, então, procedeu ilegalmente? ${ }^{316}$ [3] Bem, responderá ele ${ }^{317}$ : "Mas a lei (vómos), que proíbe matar justa e injustamente, mostra que você está sujeito às penas do homicídio, pois o homem está morto”. Mas eu afirmo pela segunda e pela terceira vez que não matei, pois se o homem tivesse morrido imediatamente pelos golpes, teria morrido por minhas mãos, sim, mas de modo justo - pois os que começaram a agressão são merecedores de sofrer de volta não só esse, mas maiores e mais em umerosos castigos. [4] Agora, se ele foi entregue muitos dias mais tarde aos cuidados de um médico incompetente, ele morreu por causa da incompetência do médico e não por causa dos golpes. Pois, mesmo sendo vocês advertidos pelos outros médicos de que, se ele recebesse esse tratamento, ainda que sendo curável sua ferida, ele morreria, e vindo a falecer graças a vocês, conselheiros da vítima, lançou-se sobre mim a acusação ímpia. [5] Absolve-me também a lei (vónos) ${ }^{318}$ pela qual estou sendo perseguido, pois ela estabelece como assassino aquele que tramou. Ora, como teria eu tramado contra ele se também ele não tivesse tramado contra mim? Pois, ao me defender dele com os mesmos $\operatorname{meios}^{319}$ e ao lhe fazer as mesmas coisas que sofri, é claro que as mesmas coisas que

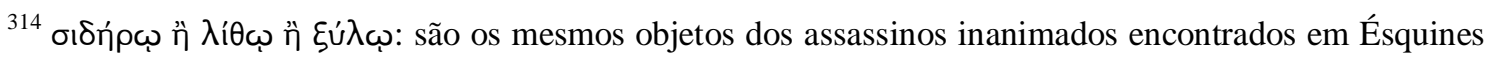
(3.244) e em Demóstenes (23.76).

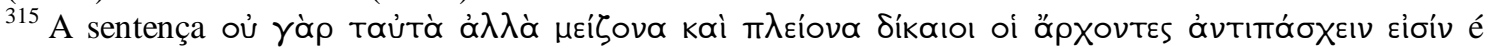

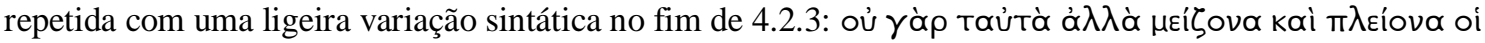

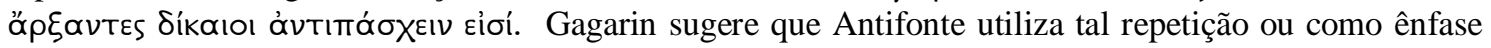
ou em virtude da falta de um argumento melhor (ANTIPHON, 1997, p.166).

${ }_{316}^{316}$ Pergunta retórica.

${ }^{317}$ Uso da figura de linguagem denominada prokatálepsis ou antecipação, estratégia retórica comum que consiste em antecipar uns dos argumentos do oponente. Ou mais precisamente, de acordo com a explicação encontrada na Retórica a Alexandre, é "o método pelo qual se antecipa as objeções que podem ser levantadas contra seus argumentos e as coloca de lado" (1439 b2 - b12) (Tradução de H. Rackham, 1957, p. 397)

${ }^{318}$ Talvez uma resposta à lei mencionada em 4.1.7.

${ }^{319}$ Ou seja, com socos. 
tramei também foram por ele tramadas. [6] E se alguém julga que a morte se deu por causa dos golpes e pensa que eu sou o seu assassino, que reflita, ao contrário, que os golpes, ocorridos graças àquele que começou a agressão, mostram que ele, e não eu, foi o próprio responsável pela morte. Pois eu não teria me defendido se não tivesse sido atacado por ele. Sendo absolvido tanto pela lei (vónou) como por aquele que começou a agressão, de modo algum sou eu o assassino do velho; por outro lado, o morto, se morreu por obra do infortúnio, foi por seu próprio infortúnio vitimado - pois teve o

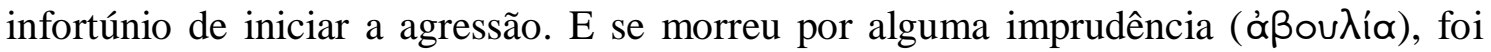
por sua própria imprudência eliminado, pois não foi raciocinando bem que me atacou.

[7] Portanto, que sou acusado injustamente, acabei de demonstrar. Quero demonstrar agora que os meus acusadores estão eles mesmos sujeitos a tudo isso de que me acusam. Ao planejarem meu assassinato, eu que sou inocente de toda a culpa, e ao me privarem da vida que a divindade me deu, cometem uma impiedade contra o deus; e ao tramarem injustamente a minha morte, não só violam as regras estabelecidas pelos homens ( $($ ó $\mu \mu \alpha)$ como tornam-se meus assassinos. Além do mais, ao persuadir os senhores a me condenar à morte impiamente, eles também acabam se tornando os assassinos da piedade dos senhores $^{320}$. [8] Quem dera, portanto, que a divindade lhes ${ }^{321}$ aplicasse o castigo. Quanto a vocês, considerando seu próprio interesse, devem decidir pela minha absolvição mais do que pela minha condenação ${ }^{322}$. Pois se eu for posto em liberdade injustamente e absolvido porque vocês não foram informados corretamente, então colocarei o espírito vingador do homem morto não sobre vocês, mas sobre aquele que não os informou corretamente ${ }^{323}$. Por outro lado, se eu for condenado incorretamente por vocês, a vocês, e não ao acusador, infligirei a cólera dos espíritos infernais. [9] Ciente, então, dessas coisas, após depositarem sobre esse homem essa impiedade, tornem-se puros e inocentes de toda a culpa e me absolvam conforme a piedade e a justiça. Pois, desse modo, todos nós cidadãos estaremos completamente purificados.

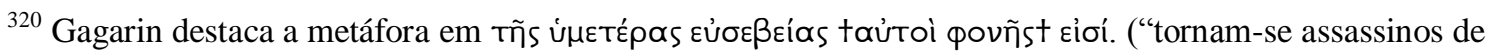
sua piedade"). Com relação às metáforas, alguns comentadores (Dobson e Cucuel) afirmam serem raras em Antifonte. De fato, é possível encontrar duas ocorrências e as duas na Tetralogia III. Cf. 4.3.6.

${ }^{321}$ Toútoıs: refere-se tanto ao acusador quanto àqueles ligados a ele.

${ }^{322}$ O sentido de $k \alpha \tau \alpha \lambda \alpha \mu \beta \alpha ́ v \omega$ como "condenar" só seria encontrado nas Tetralogias e nos fragmentos de Antifonte.

${ }^{323}$ De acordo com Gagarin, a imagem do defensor podendo recorrer à vingança do homem morto é nova (ANTIPHON, 1997, p. 167). Na tradução espanhola, José Redondo Sánchez lembra que essa é a primeira vez que a defesa recorreria em seu discurso à invocação da cólera dos espíritos vingadores (ANTIFONTE, 1991, p. 80).
} 


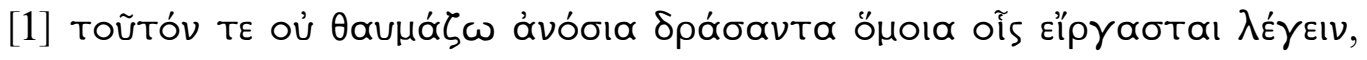

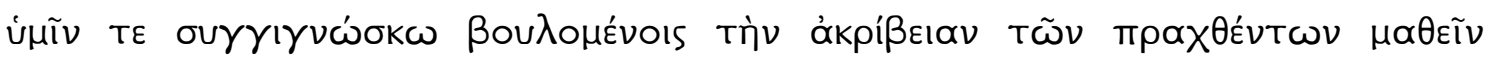

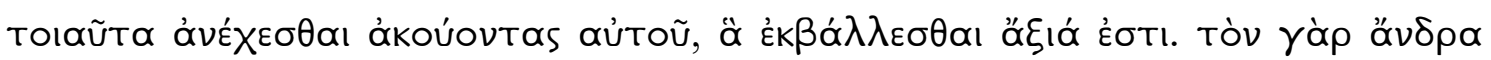

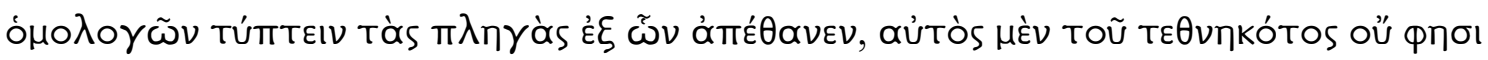

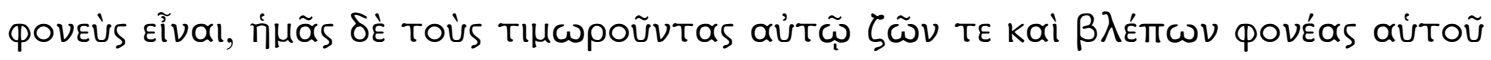

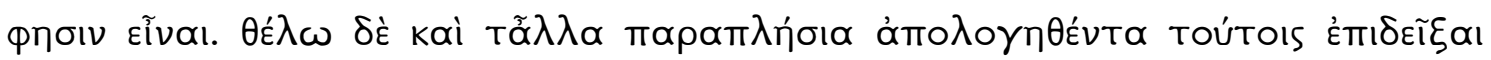
aútóv.

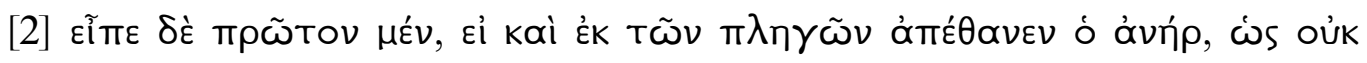

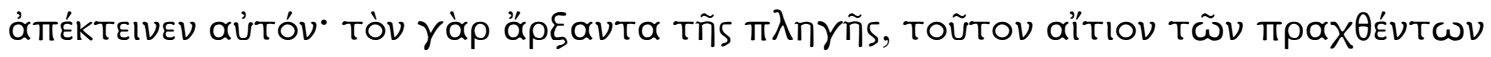

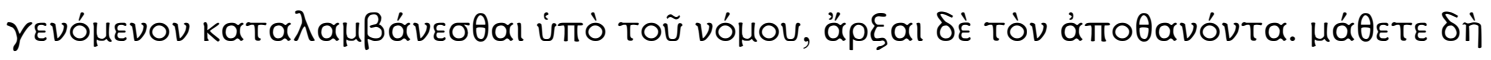
$\pi \rho \tilde{T} T$ ㅇำ

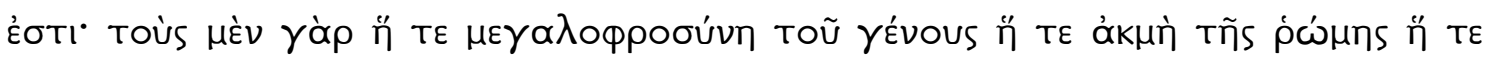

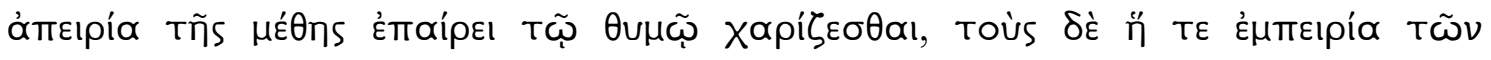

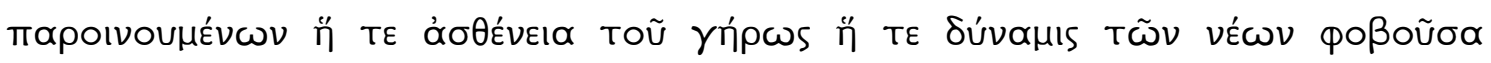

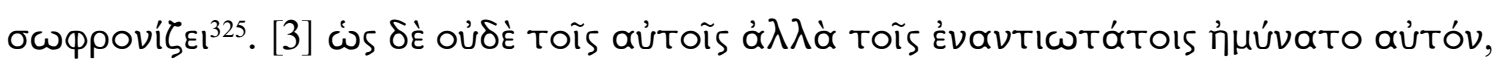

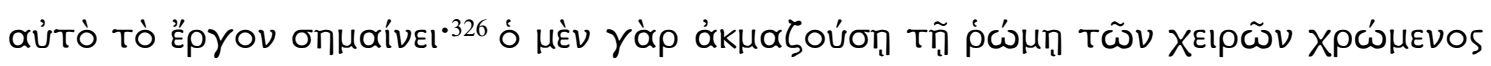

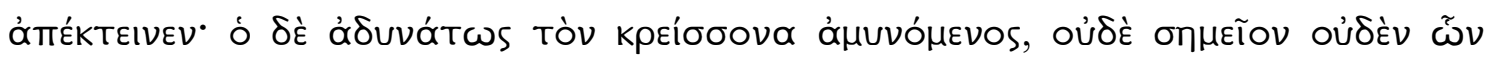

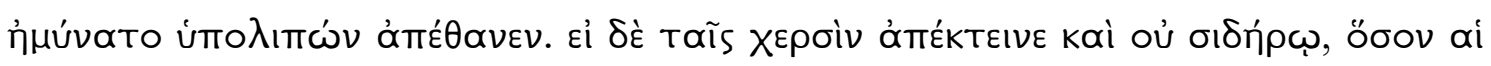

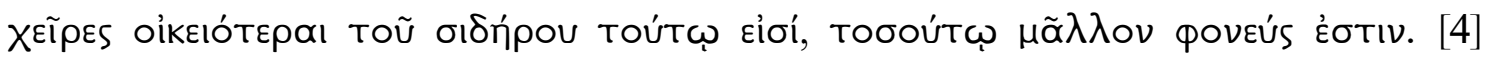

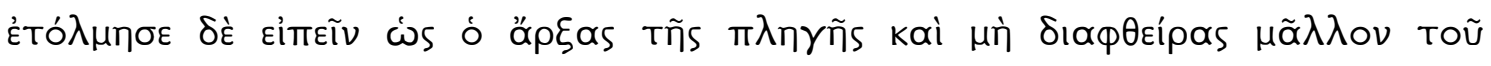

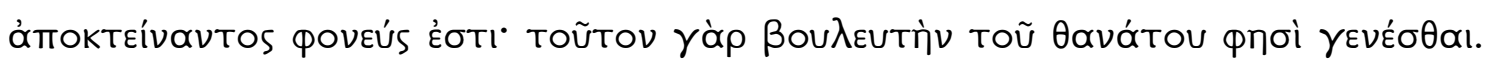

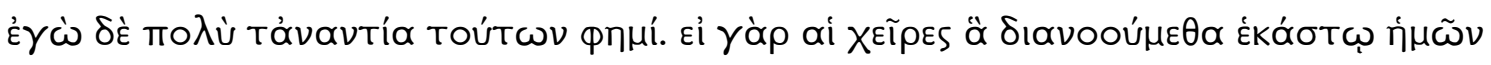

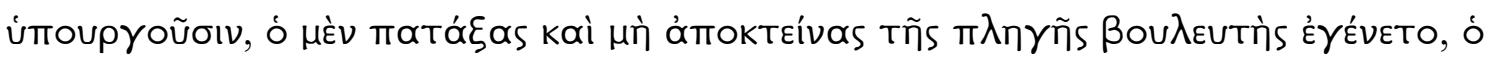

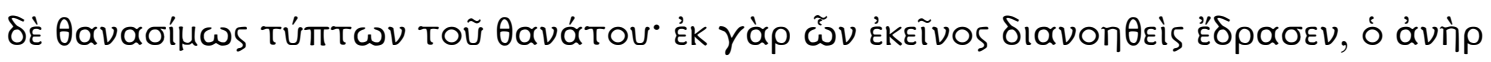

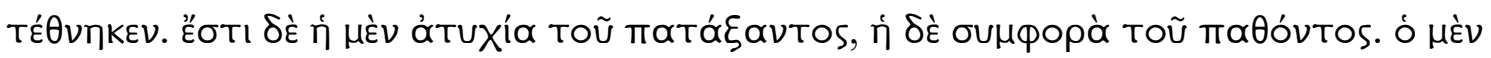

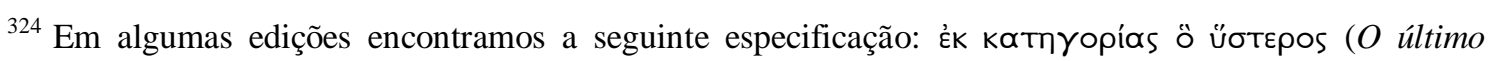
discurso da acusação).

${ }^{325}$ Uso de paralelismo do tipo isócolon para reforçar uma antítese entre um homem mais novo e um homem mais velho. Neste trecho, é possível encontrar seis expressões paralelas sem variação.

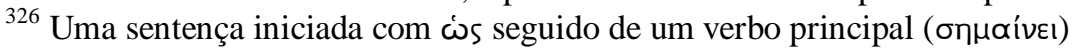




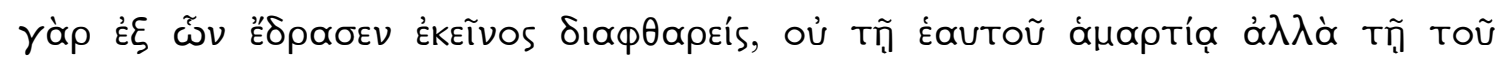

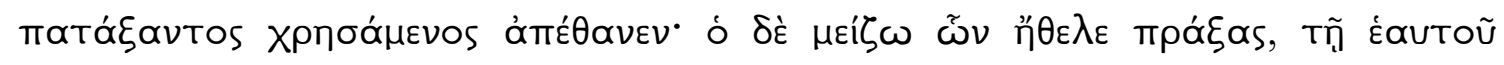

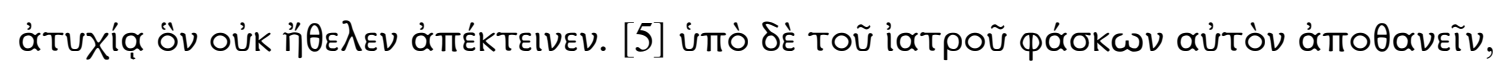

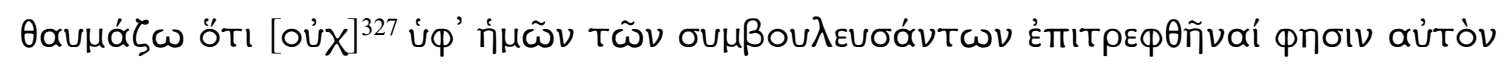

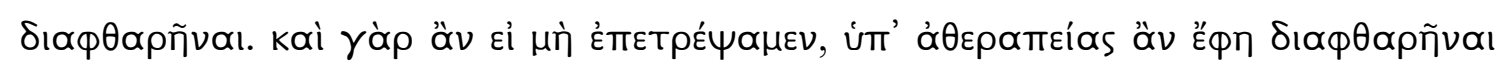

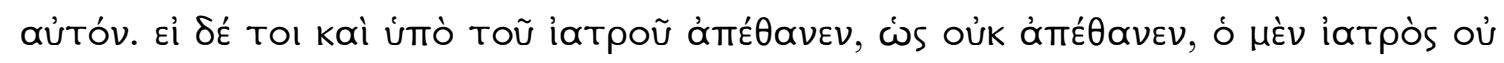

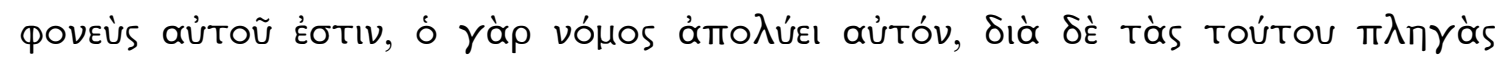

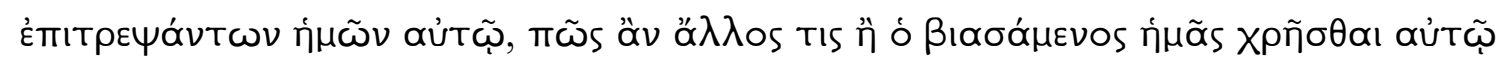

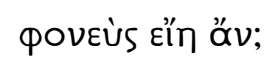

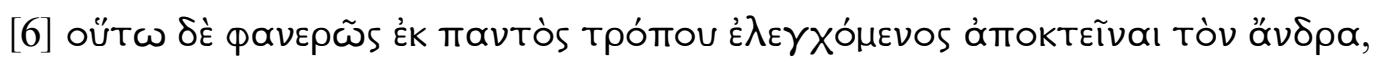

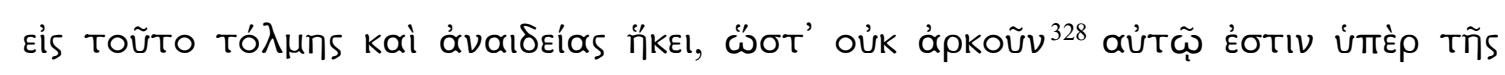

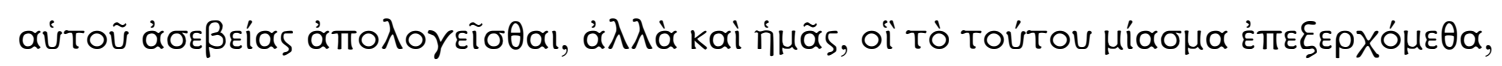

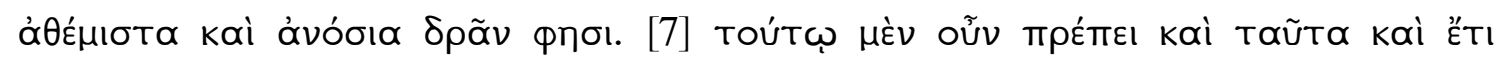

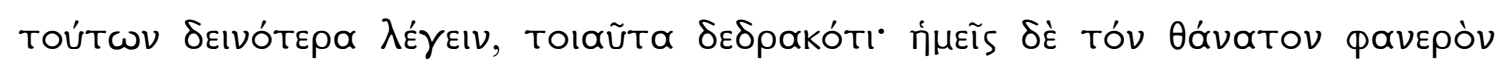

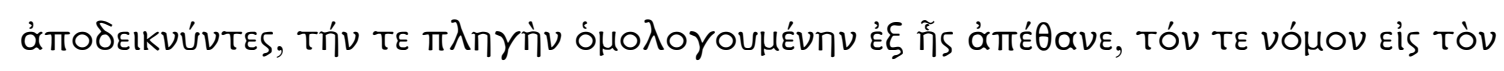

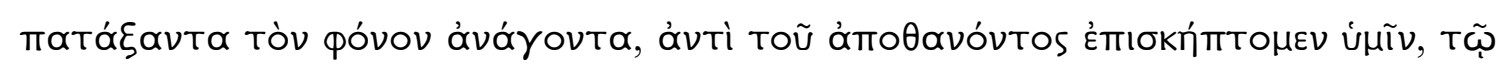

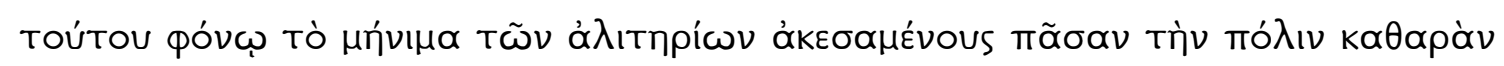

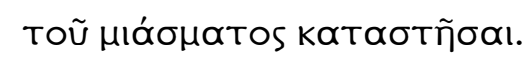

\section{3}

[1] Não me surpreende que o acusado, após ter praticado atos ímpios, faça

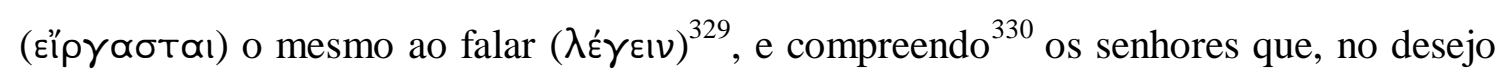
de aprenderem o sentido preciso (ákpíßєı๔v) dos eventos realizados, tolerem ouvir dele tais palavras, que são dignas de repúdio ${ }^{331}$. Pois, admitindo que deu ao homem os golpes pelos quais ele morreu, o acusado afirma que não é o assassino da vítima; por

\footnotetext{
${ }^{327}$ oủ $\mathrm{A}^{2} \mathrm{~N}$ : om. A: del.Hemstege.

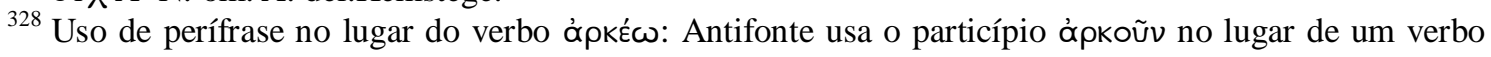
descritivo.

${ }^{329} \mathrm{Ou}$ seja, diga palavras semelhantes às suas obras. Conduta e palavra não são contrastantes, como observa Decleva-Caizzi (ANTIPHONTIS, 1969, p.250).

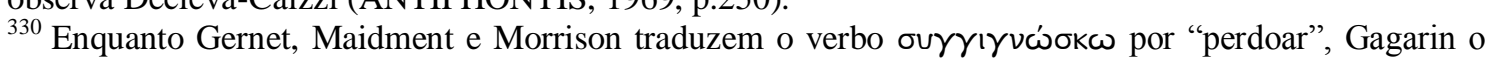
traduz por "entender", mas comportando o sentido de simpatia e perdão.

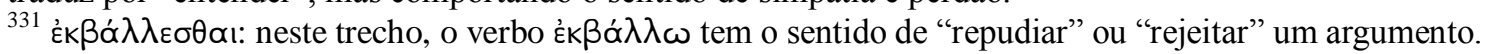


outro lado, ele, que vive e vê a luz ${ }^{332}$, afirma que nós, os vingadores do morto, somos os assassinos da vítima. Que os outros pontos argumentados em sua defesa são semelhantes a este é o que eu ainda quero demonstrar.

[2] Em primeiro lugar, ele disse que, ainda que o homem tenha morrido por causa dos golpes, não o matou, pois pela lei seria condenado aquele que começou a agressão, que vem a ser o próprio responsável pelo que aconteceu, e o que começou seria o próprio morto. Primeiramente, saibam vocês que é mais plausível (zỉkótepóv) que os mais jovens e não o mais velhos comecem uma agressão e fiquem embriagados, pois enquanto aos primeiros a arrogância natural ${ }^{333}$, a plenitude da força física e a falta de perícia com os excessos de bebida os incitam a ceder à cólera ${ }^{334}$, aos últimos a experiência com os excessos de bebida, a debilidade da velhice e o temor pela força dos jovens os fazem moderados. [3] Que ele não se defendeu com os mesmos meios, mas com meios completamente contrários, o próprio acontecimento (Épyov) ${ }^{335}$ mostra. Pois um, estando na plenitude de sua força física, assassinou fazendo uso de suas mãos; o outro, incapaz de se defender de um mais forte do que ele, morreu sem deixar para trás indícios ( $\sigma \eta \mu \varepsilon i ̃ o v)$ de como se defendeu. Se o sujeito assassinou com as mãos e não com um ferro, é tão mais assassino quanto mais ligadas a ele estão as mãos do que o ferro $^{336}$. [4] Ele se atreveu a dizer que o que começou a agressão e não matou é mais assassino do que aquele que assassinou, pois afirma que o próprio morto planejou a

${ }^{332}$ Gagarin (ANTIPHON, 1997, p. 168) nos chama a atenção para essa expressão também encontrada em

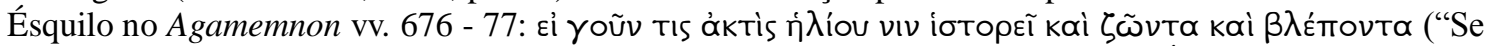
algum raio do sol o observa vivendo e vendo a luz (...)"). A essa passagem de Ésquilo, José Redondo

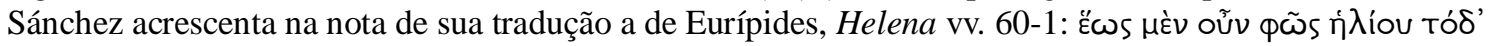

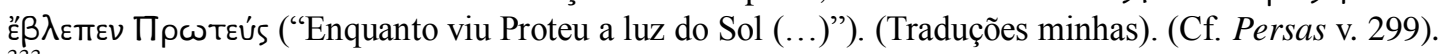

${ }^{333} \mu \varepsilon \gamma \propto \lambda$ ○ Este último comenta a opção de Morrison em traduzir esta expressão por "orgulho do nascimento" ou "orgulho da origem", mas o comentário da acusação, segundo Maidment, não se limitaria aos jovens aristocratas; o yévos deveria designar aqui "classe", "categoria" ou "tipo" (ANTIPHON, 1953, p. 130-31); Gagarin fala do jovem como um "grupo", em que o comportamento natural seria o orgulho ou arrogância decorrente da imaturidade (ANTIPHON, 1997, p. 168).

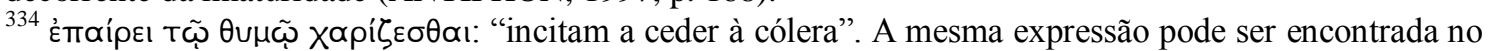
final de um fragmento atribuído a Antifonte (58 DK), no qual se lê "(...) aquele que deseja agradar ao coração de imediato, deseja as piores coisas ao invés das melhores". (Tradução minha). Outra passagem

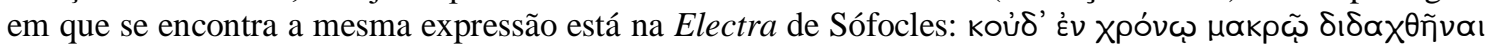

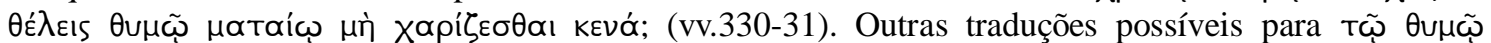
$\chi \propto \rho i \zeta \zeta \varepsilon \sigma \theta \propto ı$ seria "agradar ao coração" ou "ceder ao coração". Mas optamos por "ceder à cólera", uma vez que se trata de uma situação envolvendo agressão física e, portanto, de uma atitude colérica.

${ }^{335}$ Ou seja, o resultado da luta.

${ }^{336}$ Decleva-Caizzi sugere que a visão segundo a qual uma arma usada em um homicídio teria alguma responsabilidade pelo crime, enquanto aquele que comete um assassinato sem nenhum outro instrumento senão as próprias mãos teria toda a responsabilidade, pode se referir talvez a um conceito primitivo (ANTIPHONTIS, 1969, p. 252). 
morte. Eu afirmo totalmente o oposto disso. Pois se nossas mãos têm serventia para cada um de nós em relação àquilo que temos em mente, aquele que desferiu os golpes e não matou apenas planejou a agressão, enquanto que aquele que espancou mortalmente planejou a morte, pois o homem morreu por causa da ação planejada desse aí. O

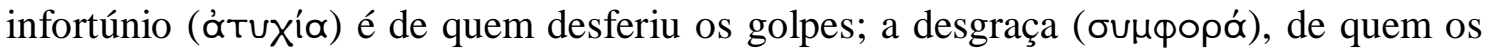
recebeu $^{337}$. Pois, por causa das coisas que um fez, o outro morreu. Logo, um morreu não por experimentar seu próprio erro, mas o erro de seu agressor; o outro, realizando coisas piores do que desejava, por seu próprio infortúnio matou quem não desejava matar ${ }^{338}$. [5] E fico surpreso que, após afirmar que o homem foi morto pelas mãos do médico, diga também que sua morte se deu pelas nossas mãos, nós que o aconselhamos a receber tratamento. Ainda que nós não tivéssemos feito isso, aquele ali teria dito que o homem fora morto pela negligência de cuidados médicos; e ainda que morresse pelas mãos do médico (o que não aconteceu), não é o médico seu assassino, pois a lei (vónos) ${ }^{339}$ o absolve. Ao ser levado por nós ao médico, por causa dos golpes sofridos, que outra pessoa teria sido o assassino do velho senão aquele que nos forçou a usá-lo ${ }^{340}$ ?

[6] Assim, mesmo provando claramente por todos os meios que o acusado assassinou o homem, ele chega a tal ponto de atrevimento e falta de vergonha ${ }^{341}$ que não lhe basta fazer a defesa de sua própria ação ímpia: ele ainda por cima afirma que nós, que estamos perseguindo o miasma do criminoso $^{342}$, realizamos ações sacrílegas e ímpias. [7] Considerando, portanto, o tipo de coisas que ele praticou, ele deve pronunciar essas coisas e outras mais terríveis do que estas. De nossa parte, tendo demonstrado que as circunstâncias da morte são claras, que há concordância de que a agressão causou a morte e que a lei ( $v o ́ \mu o v)$ faz recair o homicídio naquele que agrediu,

\footnotetext{
${ }^{337}$ Aqui, Antifonte estabelece um contraste entre ớruxía e oup popó. O primeiro se refere àquele que

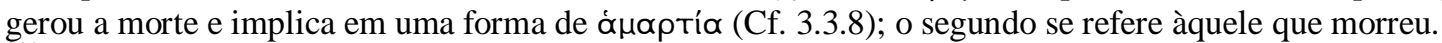

${ }^{338} \mathrm{~A}$ acusação agora admite que não foi intenção do réu assassinar a vítima, mas isso não quer dizer que ele não pretendeu agir sem violência. Como lembram Decleva-Caizi e Gagarin, essa afirmação não significa que o crime, caso não fosse hipotético, deva ser transformado em homicídio não-intencional, pois, na lei ateniense, homicídio intencional incluía assassinato com intenção de fazer algum mal ou de lesar alguém, não apenas com intenção de matar (ANTIPHONTIS, 1969, p. 253; ANTIPHON, 1997, p. 169).

${ }^{339}$ A outra evidência para essa lei que estabelece que o médico não deve ser incriminado pela morte de

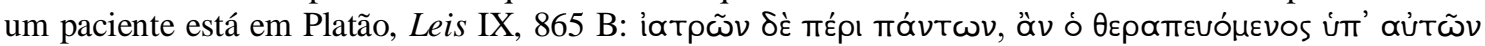

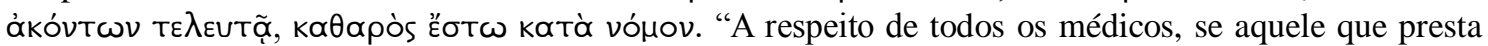
cuidados médicos causar nossa morte sem intenção, será inocente segundo a lei” (Tradução minha).

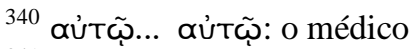

${ }^{341}$ Mesma sentença de 3.3.5

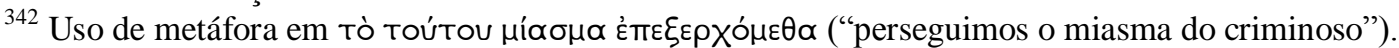


imploramos a vocês que, em nome da vítima, aplacando a cólera dos espíritos infernais pelo assassinato deste homem, deixem toda a cidade livre do miasma.

\section{$4.4^{343}$}

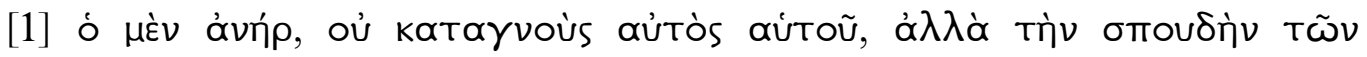

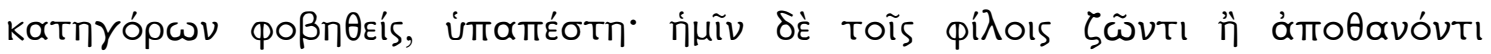

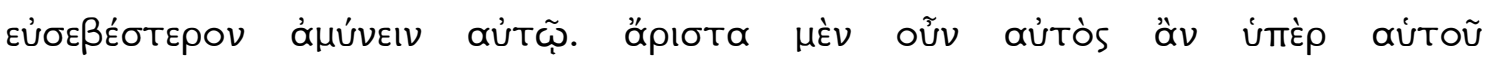

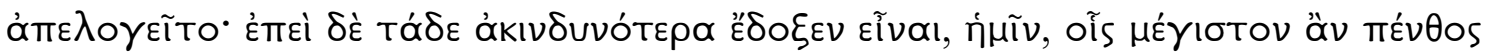

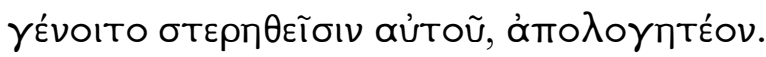

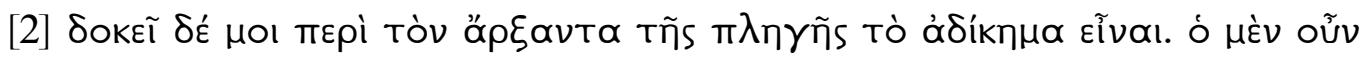

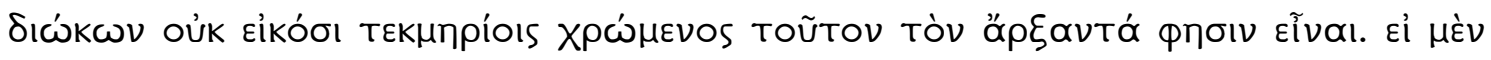

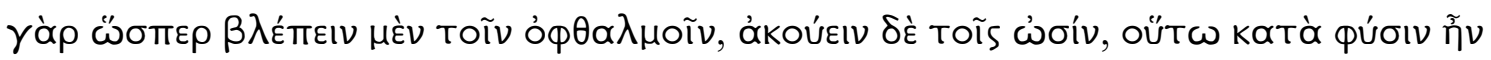

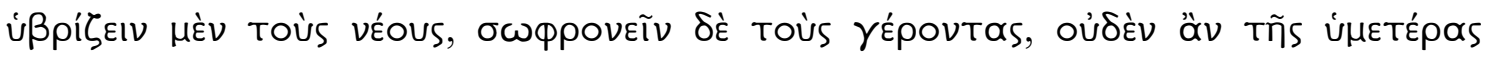

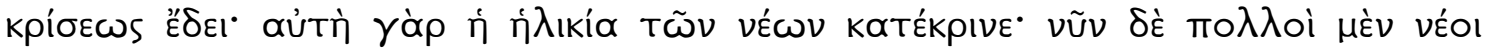

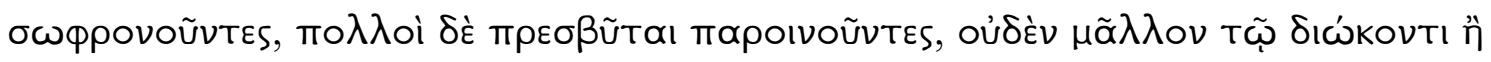

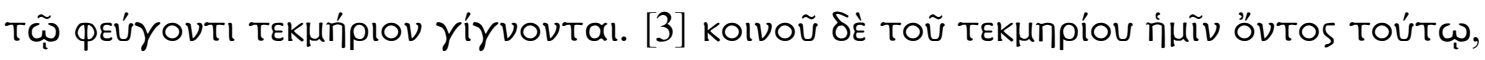

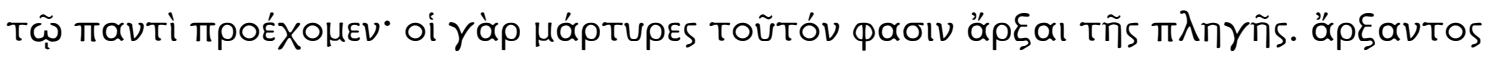

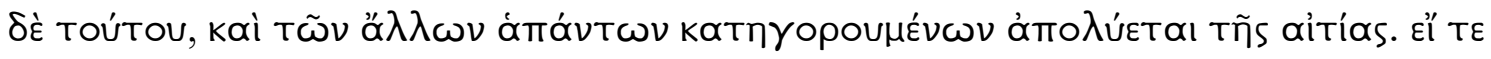

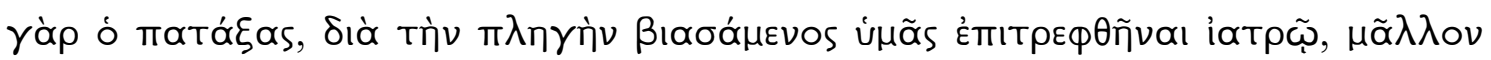

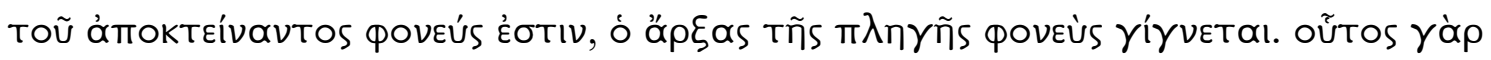

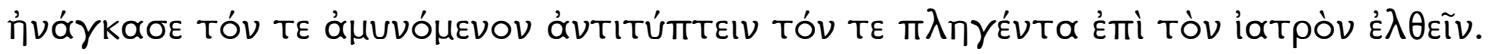

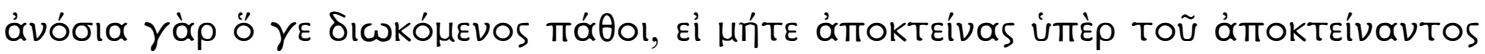

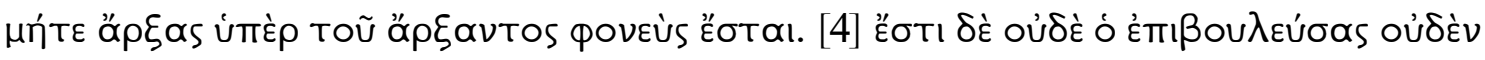

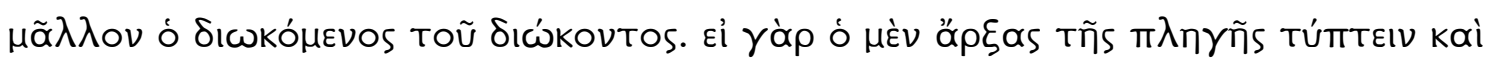

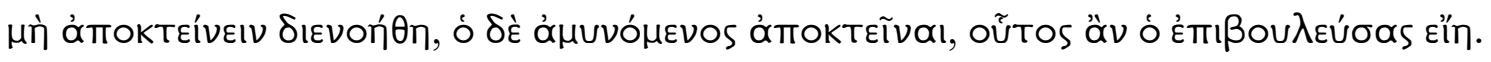

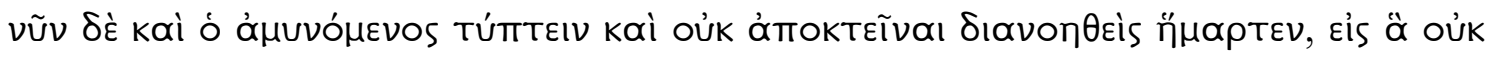

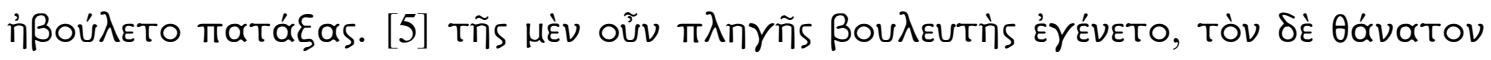
$\pi \tilde{\omega}$ ờ $\varepsilon$ Ė

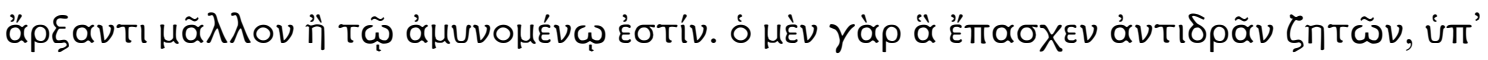

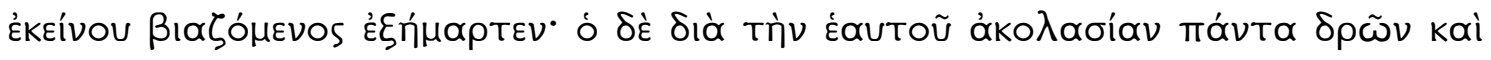

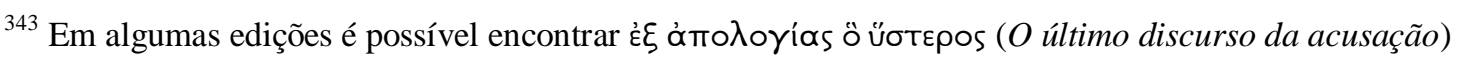




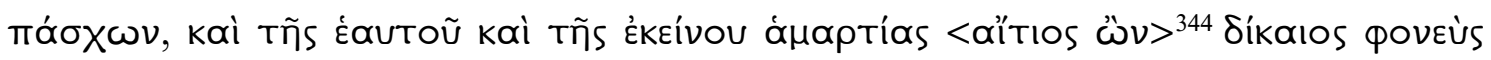

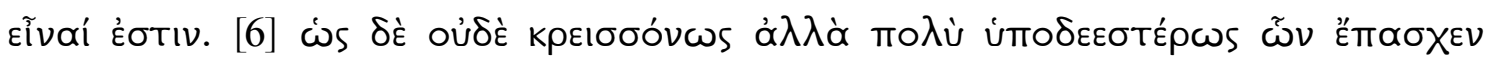

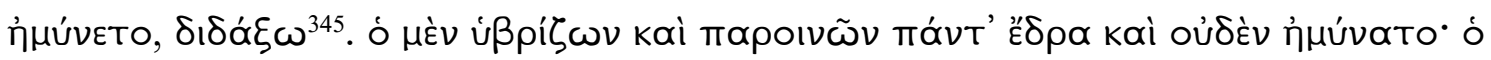

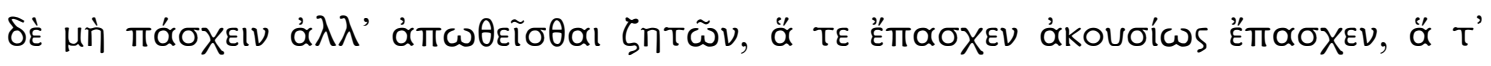

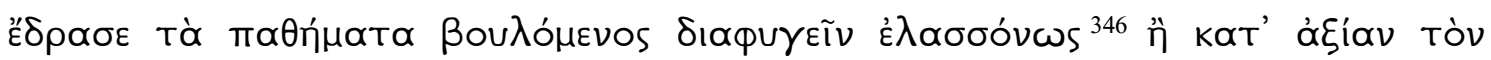

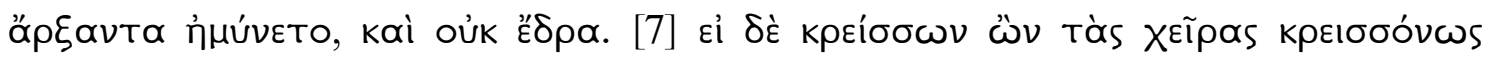

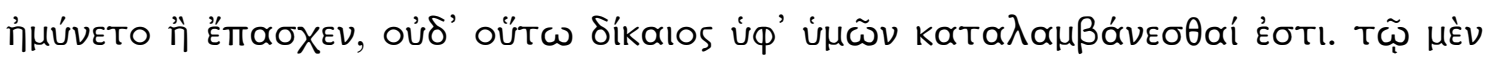

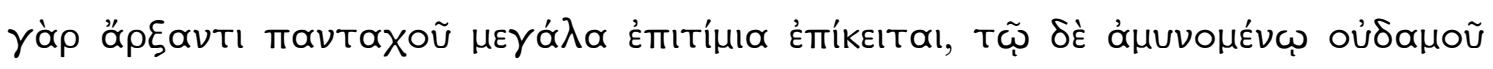

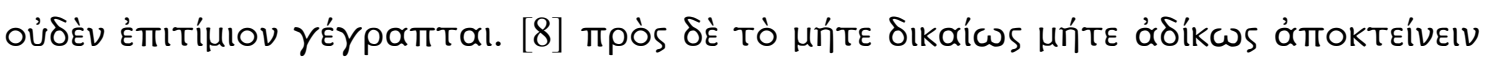

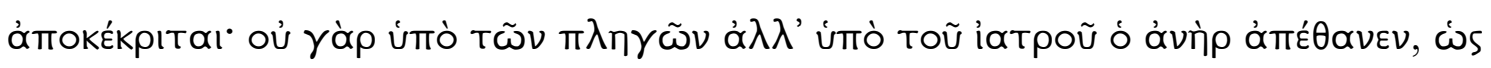

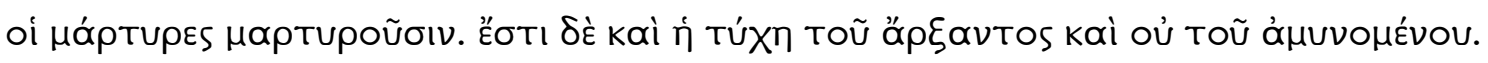

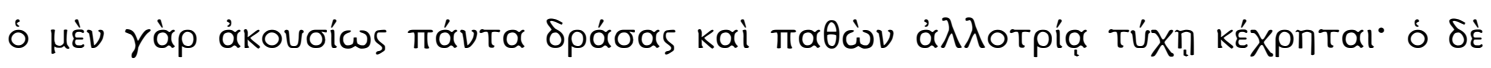

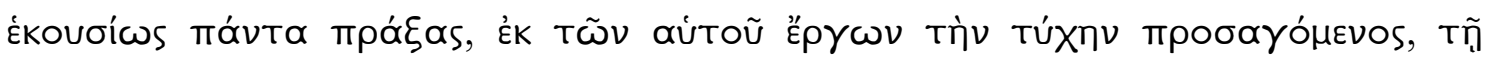

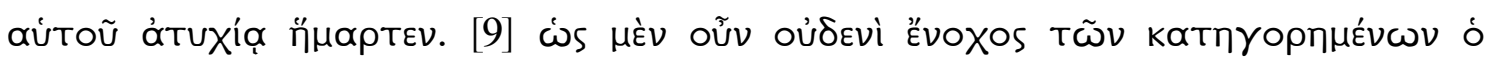

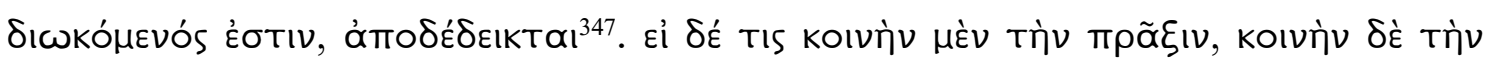

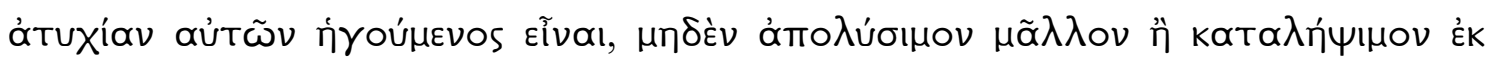

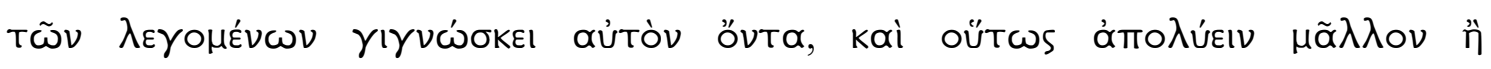

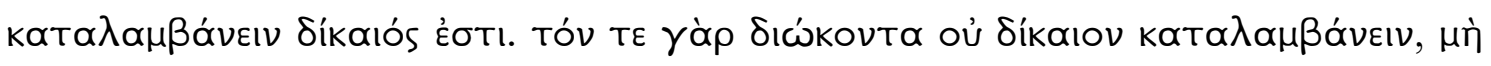

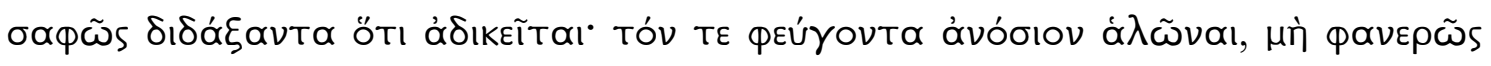

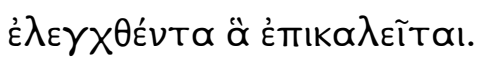

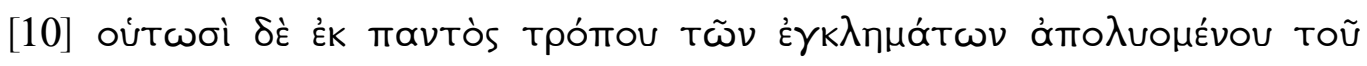

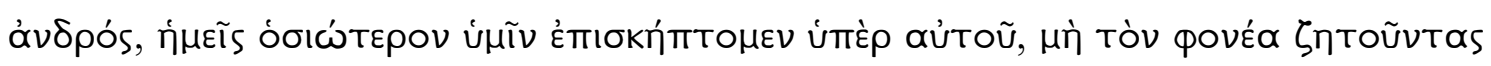

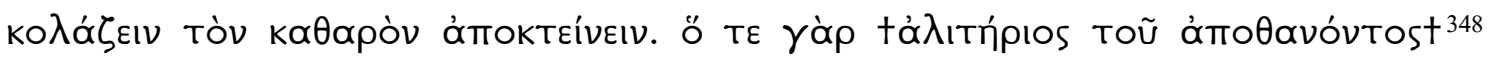

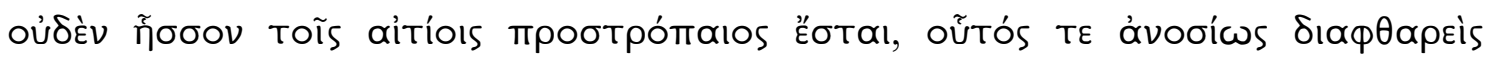

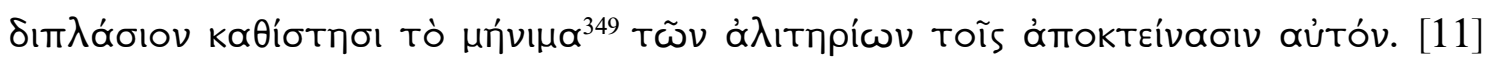

\footnotetext{
344 đîtıos ผ̌v: adição de Maetzner (Berlim, 1838)

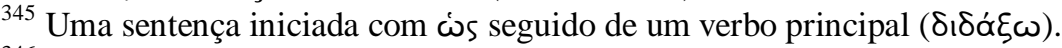

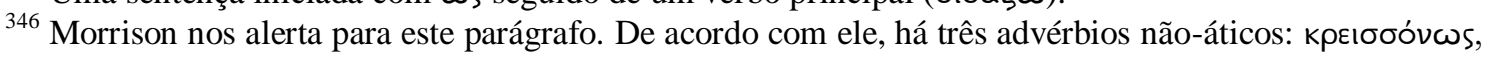

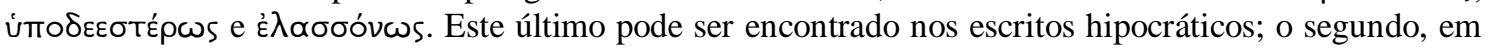
Tucídides (ANTIPHON, 2001, p. 162).

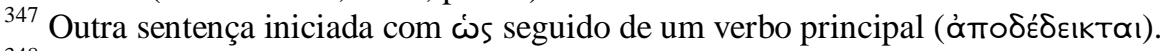

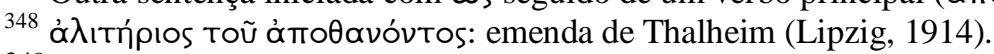

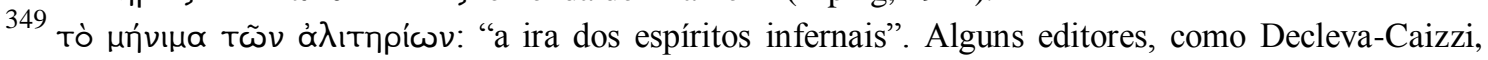

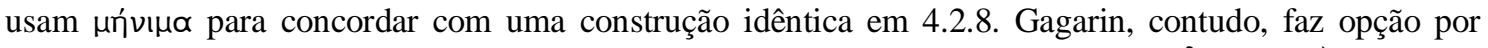

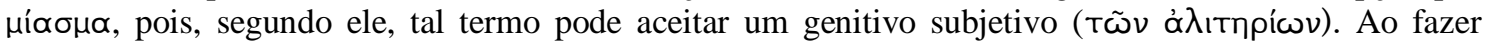

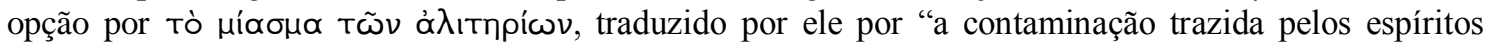




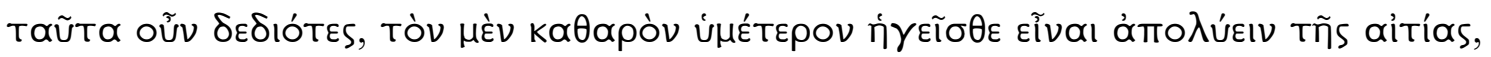

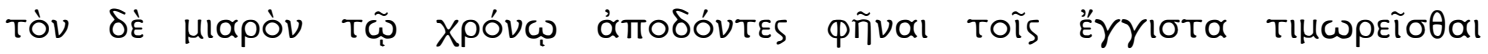

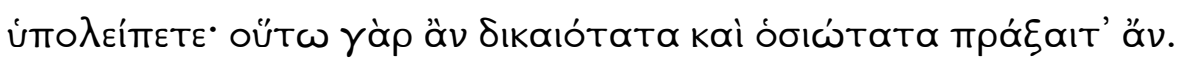

\section{4}

[1] O acusado, não porque se considerou culpado, mas porque ficou aterrorizado com a veemência dos acusadores, retirou-se para o exílio ${ }^{350}$. Para nós, os amigos, é mais piedoso defendê-lo estando ele vivo que morto. De fato, ele próprio teria falado muito melhor em sua defesa, mas porque avaliou que o exílio ${ }^{351}$ era menos arriscado, a nós, para quem a dor teria sido mais grave se fôssemos privados de sua presença, compete fazer a defesa ${ }^{352}$.

[2] Penso que a injustiça diz respeito àquele que começou a agressão. Ora, o

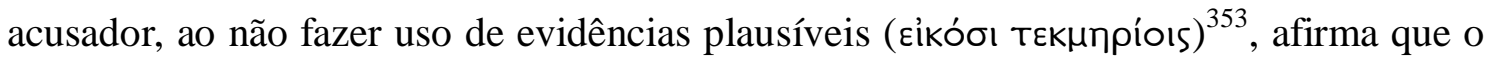
nosso amigo é o iniciador de tudo. Pois se fosse a lei da natureza (katò qúoıv) que, assim como os olhos veem e os ouvidos ouvem, os jovens não tivessem controle e os velhos fossem moderados, não seria necessário o julgamento dos senhores, pois a própria idade dos jovens os condenaria ${ }^{354}$. Agora, sendo muitos os jovens moderados e muitos os velhos que se entregam aos excessos quando se embriagam, a evidência

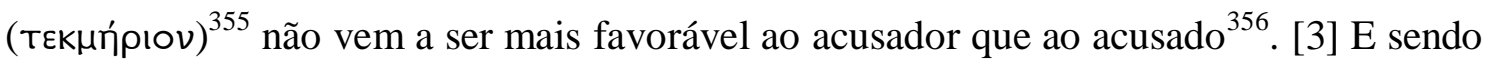

infernais", ele menciona uma passagem semelhante de Édipo Rei de Sófocles v. 1015 (ANTIPHON, 1997, p. 173). Apenas aqui divergimos da edição de Gagarin, optando pela solução de Decleva-Caizzi.

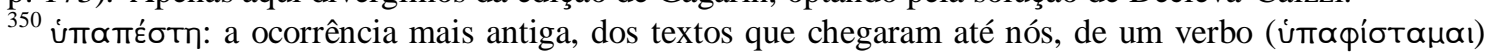
bastante raro.

${ }^{351}$ Tóde: o exílio

${ }^{352}$ Como já foi dito anteriormente, o acusado, a fim de evitar o risco de uma condenação, poderia se retirar voluntariamente para o exílio antes do início do seu segundo discurso. Isto estava previsto na legislação ateniense. (Cf. Antifonte 5.13). O discurso da defesa ficaria a cargo de algum parente ou amigo do acusado. Maidment alerta para esse "toque de realismo" nesse trecho da Tetralogia III (ANTIPHON, 1953, pp. 136-37). Para Gagarin, a retirada do defensor poderia sugerir a construção de um discurso mais fraco por parte de Antifonte, ou então, a construção de uma situação que lhe possibilitaria explorar outros argumentos relevantes para essa situação (GAGARIN, 2002, p. 130).

${ }^{353}$ Antifonte utiliza, inicialmente, as evidências baseadas no kikós e não acena para os testemunhos.

${ }^{354}$ Para Gagarin, Antifonte faz neste parágrafo a importante distinção entre o que é razoável ou plausível e o que é necessário segundo a natureza (ká tà qúoıv). A vista e o ouvido são citados como exemplos típicos de funções naturais, katà qúoıv. Tanto Gagarin quanto Decleva-Caizzi fazem menção ao fragmento do Sobre a Verdade em que Antifonte faz a distinção entre funções naturais, como respirar com o nariz e ver com os olhos, e as regras (vónos) impostas a essas funções. (ANTIPHON, 1997, p. 171; ANTIPHONTIS, 1969, p. 256) .

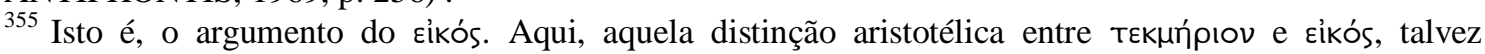
presente na Tetralogia I, não parece ser seguida. 


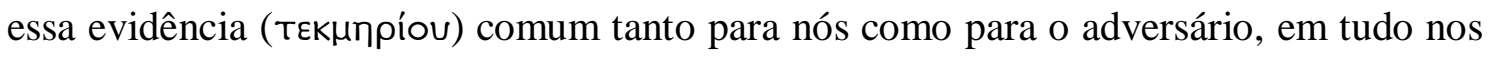
sobressaímos, pois os testemunhos (нáptupєs) afirmam que a vítima começou a agressão. Haja vista que ela começou, o acusado está livre da culpa também de todas as outras acusações. Pois se o agressor ${ }^{357}$, por causa do golpe que os obrigou a recorrer a um médico, é o assassino mais do que o autor da morte ${ }^{358}$, aquele que começou a agressão vem a ser o assassino. Pois forçou um que estava em posição de defesa a dar o contragolpe e ao golpeado, no caso o morto, a recorrer à ajuda de um médico. O acusado sofreria ações ímpias se, sem ter matado, fosse declarado assassino no lugar de quem realmente matou ${ }^{359}$, e, sem ter começado, no lugar daquele que começou a agressão $^{360}$. [4] Quanto ao planejamento da morte, não é do acusado mais que do acusador. Pois se fosse o caso de que aquele que começou a agressão tinha intenção de espancar e não matar, enquanto que o que se defendeu tinha intenção de matar, este último teria de ser o responsável pelo planejamento da morte. Agora, o que se defendeu também errou (I̋ $\mu \propto \rho \tau \varepsilon v)^{361}$ ao revidar, ainda que não tivesse intenção de matar, porque acabou desferindo os golpes com um efeito que ele não pretendia. [5] Ele, portanto, planejou o golpe. Mas de que modo planejou a morte se ele desferiu os golpes não como

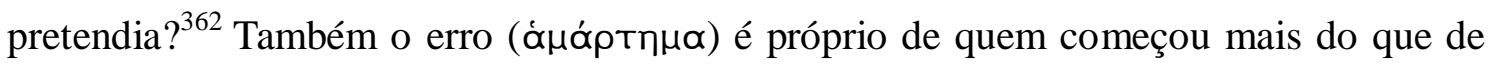
quem se defendeu. Pois, um, buscando devolver, por sua vez, o que tinha sofrido, errou ainda que forçado por aquele homem; o outro, fazendo e sofrendo tudo isso por causa de sua falta de auto-controle e sendo o responsável por seu próprio erro e pelo erro do acusado, é justo que seja o assassino. [6] Que o acusado não se defendeu mais fortemente dos golpes que sofreu, mas de modo muito mais fraco, é o que demonstrarei. Enquanto um, estando tomado pela desmedida e pela embriaguez, tudo fez e não se defendeu, o outro, procurando não sofrer os golpes, mas repeli-los, acabou sofrendo sem intenção o que sofreu; e com respeito à sua ação, ao querer evitar os sofrimentos,

\footnotetext{
${ }^{356}$ Gernet vê uma característica de um modo de ser tipicamente sofístico nessa discussão que visa

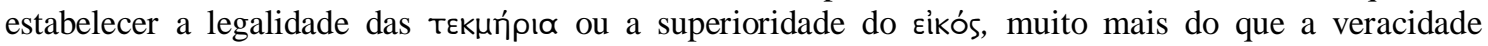
histórica dos fatos. (GERNET, 1954, p. 97)

357 ó ma Tákas: "o que deu os golpes", isto é, o acusado.

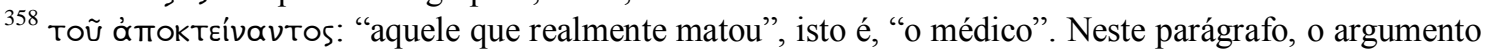
da defesa estabelece uma cadeia de causalidade ao mover a responsabilidade do autor imediato da morte (o médico, que com sua incompetência provocou a morte) para a vítima (a pessoa que iniciou a agressão), passando por aquele que se defendeu da agressão (o acusado).

${ }^{359}$ Isto é, o médico.

${ }^{360}$ Isto é, a vítima.

${ }^{361}$ Ainda que a defesa possa admitir que houve um erro por parte do acusado, ela, na sequência, procura transferir esse erro para a vítima.

${ }^{362}$ Uma pergunta retórica.
} 
defendeu-se daquele que iniciou os golpes de modo menos intenso do que este merecia e não cometeu efetivamente uma agressão. [7] E se ele, sendo mais forte de braço, se defendeu de maneira mais forte que a que sofreu, nem mesmo assim é justo que ele seja condenado pelos senhores, pois grandes penalidades são impostas, em todos os lugares $^{363}$, àquele que começou a agressão, e nenhuma penalidade, em lugar nenhum, é escrita para aquele que se defende. [8] Com relação à ação de matar - seja de modo justo seja de modo injusto -, ela já foi respondida: o homem morreu não por conta dos golpes, mas por culpa do médico, como os testemunhos confirmam. A desventura é do iniciador da agressão e não daquele que se defendeu. Pois um, fazendo e sofrendo tudo isso de forma não-intencional, se encontra envolto em uma desventura alheia, enquanto o autor intencional de tudo isso, a partir de sua própria ação, errou por seu próprio infortúnio ao trazer sobre si mesmo a desventura. [9] Portanto, que o acusado não é culpado de nenhuma das acusações já está demonstrado. Mas se alguém, ao julgar ser comum não só a ação da vítima, mas também seu infortúnio, percebe que, a partir dos argumentos apresentados, o acusado não é merecedor de absolvição mais do que de condenação, também assim é justo absolvê-lo mais do que condená-lo. Pois não é justo que seu acusador condene sem informar claramente que o jovem está sendo injustiçado; e não é piedoso que o acusado seja sentenciado sem terem sido provadas claramente as acusações as quais lhe imputam.

[10] Assim, absolvendo este homem de todas as formas de acusação, nós, em nome dele, pedimos a vocês, do modo mais piedoso possível, que, buscando castigar o assassino, não matem um inocente. Pois o espírito do morto não será menos vingativo para com os responsáveis; e este homem, se for eliminado impiamente, duplicará ${ }^{364}$ a ira dos espíritos infernais contra os seus assassinos. [11] Temendo, então, isso tudo, considerem seu dever livrar o inocente da responsabilidade pelo homicídio e, confiando ao tempo que revele o homem manchado de sangue, deixem aos parentes mais próximos a realização da vingança. Pois assim vocês agiriam da maneira mais justa e mais piedosa.

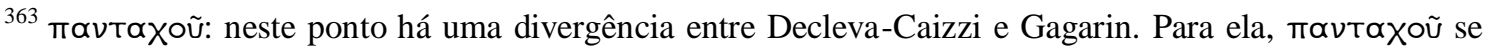
refere a uma lei não-escrita universal (ANTIPHONTIS, 1969, p. 259); para Gagarin, faz referência às leis escritas de todas as cidades gregas, e a indicação disso está na referência subsequente à "penalidade

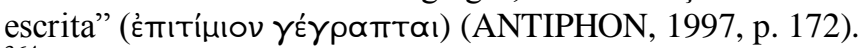

${ }^{364}$ Por não se ter vingado o homem assassinado e por se ter condenado à morte um inocente.
} 


\section{COMENTÁRIOS DAS TETRALOGIAS}

\subsection{Comentário da Tetralogia I}

O caso hipotético de homicídio apresentado por Antifonte na Tetralogia I diz respeito ao assassinato de um homem no meio da noite; seu empregado, um escravo, também foi morto no ataque, mas teria vivido o suficiente para incriminar o réu, inimigo de longa data da vítima. Em um tribunal hipotético, a acusação será feita por um parente da vítima, enquanto que a defesa, pelo próprio acusado.

Diferentemente das outras duas Tetralogias, nesta Antifonte elabora um caso em que os fatos estão em disputa, visto que não há evidência direta do assassinato. A evidência do escravo, morto, não pode ser verificada sob tortura, como era habitual na lei ateniense, e é, desde o princípio, questionada. Além do mais, não há outras testemunhas oculares e, inicialmente, nenhuma outra prova determinante é fornecida. Diante da falta de evidências fundamentais para o caso, alguns argumentos serão elaborados pelos litigantes, muitos dos quais sob a forma de argumentos do eíkós.

\subsubsection{Da Disposição dos discursos}

Em primeiro lugar, um problema a ser ressaltado diz respeito à natureza do caso das Tetralogias e à forma como o autor as compõe. Conforme referido em 1.2, esses discursos diferem, em alguns aspectos, dos discursos que seriam efetivamente apresentados em um tribunal. Na Tetralogia I, especificamente, o caso não pode, à primeira vista, ser definido como homicídio intencional como geralmente se define, pois os fatos estão em disputa; enquanto a acusação sustenta a premeditação do crime, o réu alega inocência. Além do mais, em todas as Tetralogias as testemunhas não são chamadas, embora se avente a possibilidade disso. Tudo indica que a ausência de testemunhas permitiria a Antifonte desenvolver, sobretudo, as argumentações em discursos hipotéticos que são exercícios argumentativos e não discursos compostos para serem apresentados a juízes em um tribunal ${ }^{365}$. Uma Tetralogia em que os fatos fossem decididos pela evidência da testemunha seria de pouco interesse pedagógico ou teórico. Quanto às narrativas, elas são pouco desenvolvidas, quando não omitidas, a exemplo

${ }^{365}$ As testemunhas serão utilizadas, por exemplo, em Antifonte 5 (29-42 e 46-52) e 6 (23-32). 
desta Tetralogia I. A diminuição da importância da narrativa pode ser compreensível, nesse caso, por se tratar não tão somente de um caso hipotético, mas, sobretudo, de uma circunstância em que os fatos não são claros.

Parece problemático analisar as estruturas dos discursos de cada uma das Tetralogias a partir do arranjo tradicional de um discurso em quatro partes (proêmio, narrativa, provas ou argumentos e epílogo), porque, por um lado, acredita-se que essa divisão canônica das partes de um discurso tenha sido elaborada apenas posteriormente pela preceptiva retórica, não podendo ser datada com segurança antes do século IV a.C. ${ }^{366}$; por outro lado, em alguns discursos gregos - não apenas áticos - do século $\mathrm{V}$ a.C., a seção identificada como uma narrativa algumas vezes está ausente ou é bastante curta e pouco desenvolvida, ou, ainda, surge de forma deslocada no texto ${ }^{367}$. É possível, como aventou Schiappa ${ }^{368}$, que no século V a.C. uma organização de um discurso em três partes (introdução, argumento e conclusão), sem uma narrativa explícita, poderia ser o resultado de uma transposição de uma composição em anel (os chamados "ring compositions") para discursos em prosa, mais do que uma teoria particular da disposição de um discurso. Essa organização com início e fim retomando a mesma ideia inicial seria comum no período arcaico, podendo ser encontrada na épica homérica ${ }^{369}$,

\footnotetext{
${ }^{366}$ Cf. E. Schiappa (SCHIAPPA, 1999, p. 44) e T. Cole (COLE, 1991, p. 82-3).
}

Não é possível averiguar quem, de fato, estabeleceu pela primeira vez o arranjo em quatro partes de um discurso. No Fedro (266d7-e6), ele é creditado a Teodoro de Bizâncio, com acréscimos de partes de Eveno de Paros. Credita-se também a Protágoras (DK 80A I). As evidências que atribuem a Córax um arranjo das partes são posteriores e estão em desacordo quanto ao número (três, quatro, cinco ou sete).

${ }^{367} \mathrm{~A}$ evidência para as teorias posteriores do século $\mathrm{V}$ do arranjo em quatro partes do discurso talvez esteja em alguns discursos do século V e no Fedro de Platão (266d5-267d4). Entre os discursos, seguindo a indicação de Michael de Brauw, Elogio de Helena de Górgias, um discurso de Medéia para Jasão (vv. 465-519) na tragédia Medéia de Eurípides e Antifonte 1, à primeira vista, é possível encontrar as quatro partes do discurso. (BRAUW, 2007, p. 189). No entanto, há dúvidas quanto à seção identificada como uma narrativa (ou é extremamente curta, ou pouco desenvolvida, ou deslocada). Seria o caso também dos outros dois discursos para Tribunal de Antifonte. Ainda que as quatro partes sejam mantidas, o autor ou não segue rigorosamente a ordem (Antifonte 6: proêmio, narrativa, argumentos, narrativa, testemunhos, argumentos e epílogo), ou a narrativa e as provas estão misturadas (Antifonte 5). No Fedro, por sua vez, ao fazer um breve resumo das contribuições dos livros da arte do discurso (266d-267d) creditado a Teodoro, Sócrates declara que eles indicariam as partes normalmente aceitas em todo discurso: o orador

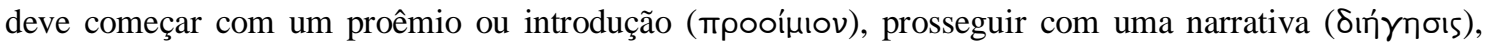

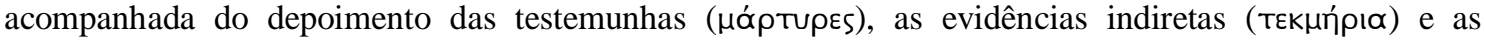

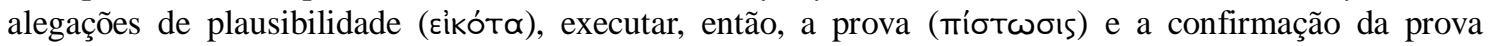
( vista, Sócrates esteja listando as quatro partes em sua ordem canônica, ele introduz mais elementos, como

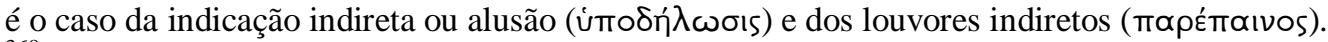

${ }^{368}$ SCHIAPPA, 1999, p. 44

${ }^{369}$ Ibid., p. 44 
sobretudo nos discursos das personagens em assembleias, como os de Nestor na Ilíada $(1.254-284 ; 7.124-160 ; 11.656-803 ; 23.626-650)^{370}$.

Um detalhe importante observado por Michael de Brauw ${ }^{371}$, é que um discurso do século $\mathrm{V}$ a.C. contendo quatro partes não necessariamente provaria a existência de uma teoria do arranjo já nesse período, pois o começo e o fim normalmente são considerados partes especiais de um discurso, e no caso de um discurso judicial - como os três discursos forenses de Antifonte -, é natural que aquele que apresente sua defesa ou sua acusação dê a sua versão dos eventos (uma narrativa) e prove (ou argumente) que os eventos ocorreram como ele afirma ${ }^{372}$. No mais, essa disposição poderia facilmente ter produzido uma teorização subsequente da divisão em quatro partes de um discurso.

Ainda que alguns textos não apresentem uma narrativa propriamente dita, caso da Tetralogia I, ou façam uma breve declaração dos fatos - Tetralogia II (3.1.1) e Tetralogia III (4.1.6) -, os eventos, em alguma medida, podem ser compreendidos através dos argumentos oferecidos pelos litigantes entre os proêmios e os epílogos, ou mesmo neles. Nessas duas partes, que em geral têm funções bem precisas ${ }^{373}$, Antifonte dedica-se, principalmente, a expôr uma crença religiosa do miasma bastante elaborada.

Com respeito à extensão dos discursos, ainda que, como lembra Kennedy ${ }^{374}$, não fossem incomuns discursos judiciais gregos bastante curtos ${ }^{375}$, é evidente o tamanho reduzido das Tetralogias, sobretudo das Tetralogias II e III.

Se pensássemos, então, em uma estrutura mais esquemática do texto da Tetralogia I, ela poderia ser apresentada da seguinte maneira: ${ }^{376}$

\section{Primeiro discurso da acusação (2.1)}

Proêmio (1-3): considerações gerais sobre a natureza do caso. A acusação, em primeiro lugar, alega que, por se tratar de um crime muito bem planejado e com pouca evidência direta, a argumentação usada no caso será calcada no eỉkós; em segundo lugar,

\footnotetext{
${ }^{370}$ Cf. TOOHEY, 1994, pp. 153-75.

${ }^{371}$ BRAUW, 2007, pp. 189-90.

${ }^{372}$ Ibid., p. 190

${ }^{373}$ Pensando já na divisão das partes, se a função tradicional de um proêmio é informar, atrair a atenção e conquistar a boa vontade dos ouvintes, a do epílogo é recapitular os principais pontos do discurso, despertar as emoções da audiência e dispor essa audiência favoravelmente ao orador e desfavoravelmente ao oponente (Cf. BRAUW, 2007, pp. 191e 196 ).

${ }^{374}$ KENNEDY, 1980, p. 27.

${ }^{375}$ Cf. Antifonte 1; Isócrates 20; Iseo 4; Lísias 10.

${ }^{376}$ O esquema que seguimos é o proposto por Gagarin em Antiphon, The Speeches (1997).
} 
que o miasma do homicídio recairá sobre a cidade caso o verdadeiro assassino não seja condenado.

Argumentação (4-9): pela argumentação apagógica ${ }^{377}$, a acusação elimina outros suspeitos e incrimina o principal inimigo da vítima, elencando os possíveis motivos para o crime. O testemunho reportado de um escravo é utilizado como principal evidência de que se trata de um homicídio premeditado.

Epílogo (9-11): a acusação retoma os pontos mencionados no proêmio e reforça a ideia do miasma decorrente do crime de sangue.

\section{Primeiro discurso da defesa (2.2)}

Proêmio (1-4): exposição sobre sua situação pessoal. A defesa utiliza o mesmo procedimento empregado pela acusação: os argumentos do દíkós.

Argumentação (5-10): a defesa elenca as muitas situações possíveis para o homicídio. O testemunho do escravo não pode ser utilizado como prova confiável. A defesa inverte os argumentos do eíkós empregados pela acusação.

Epílogo (11-13): réplica ao argumento do miasma: a contaminação do homicídio recairá sobre a cidade e sobre os juízes caso um inocente seja condenado. A defesa menciona os inúmeros serviços públicos desempenhados por ela na cidade.

\section{Segundo discurso da acusação (2.3)}

Proêmio (1): resposta ao início do discurso da defesa que enfatizou sua situação desafortunada. A acusação reforça se tratar de crime premeditado.

Argumentação (2-8): Contra-argumento do discurso anterior da defesa: a acusação rebate as situações possíveis para o homicídio sugeridas pela defesa. Além de defender a confiabilidade do testemunho do escravo, a acusação defende que o argumento do eikós é a melhor prova da culpabilidade do réu.

Epílogo (9-11): réplica do argumento do miasma: o espírito encolerizado do morto se voltará contra os juízes no caso de absolvição do culpado e a cidade permanecerá impura.

\section{Segundo discurso da defesa (2.4)}

Proêmio (1-4): exposição acerca de sua situação desafortunada. A defesa suplica aos juízes por sua absolvição.

Argumentação (4-10): a defesa rebate os muitos argumentos da acusação. Uma defesa será baseada no álibi.

${ }^{377} \mathrm{O}$ uso dessa forma de argumentação por Antifonte será discutido mais a frente. 
Epílogo (10-12): retomada do argumento do miasma. A defesa reafirma sua inocência e reforça a necessidade de expiação da morte.

\subsubsection{O Eikós}

Na Tetralogia I, Antifonte construirá o caso de modo a se concentrar naquelas suposições ou expectativas mais plausíveis ou razoáveis de como um homem comum teria agido: os Eikóta. Embora ele avente também a possibilidade da utilização da

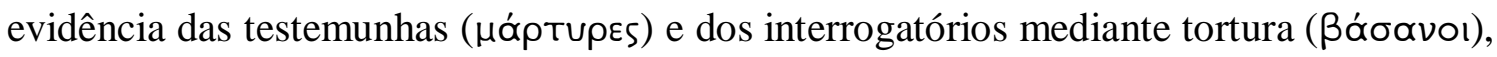

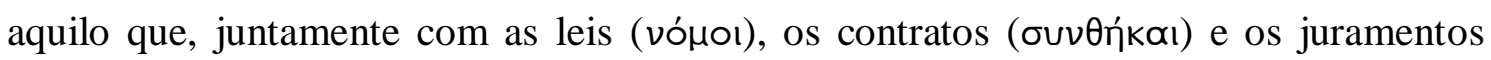

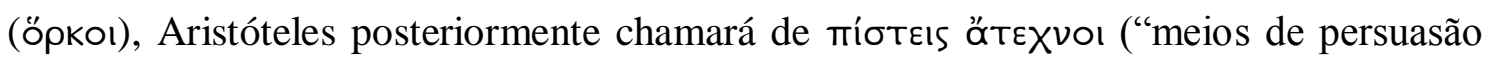
não artísticos”) e que são características principalmente da oratória judicial, Antifonte manipula essas míoteıs de modo que tenham pouca ou nenhuma relevância para o caso. Com efeito, o autor parece mais interessado nos argumentos do Eíkós, ou seja, nas evidências indiretas construídas com base nos argumentos desenvolvidos pelos litigantes, o que Aristóteles chamará de míotels évTEXvol ("meios de persuasão $\operatorname{artísticos")})^{378}$.

Os argumentos do eíkós geralmente são aplicados em circunstâncias nas quais os fatos estão em disputa e a evidência direta está ausente ou é questionável, como é o caso desta Tetralogia, em que se discute quem cometeu um homicídio. Em linhas gerais, eles se referem às expectativas razoáveis com relação à conduta humana: o que se supõe que um homem deve naturalmente fazer. Em outras palavras, esse argumento lida com situações envolvendo seres humanos que não necessariamente tenham ocorrido, mas que são aceitáveis porque, na maioria das vezes, são corroboradas pela experiência comum.

As análises contidas na Retórica a Alexandre e na Retórica de Aristóteles, e mesmo no Fedro de Platão, podem ser úteis para um melhor entendimento do uso

\footnotetext{
${ }^{378}$ No livro I (1355b36-1377b12), Aristóteles identifica as três míoteıs (ou meios de persuasão) fornecidas pelo discurso: umas são fornecidas pelo caráter moral ( $\left.\varepsilon^{\prime} \theta \circ \varsigma\right)$ do orador; outras pelo modo como o orador e o discurso afetam a emoção (mó́tos) da audiência; e outras, pelo próprio discurso ( $\lambda$ óyos). Quanto a esse último, Aristóteles lida com o que ele chama de técnicas artísticas - o uso de

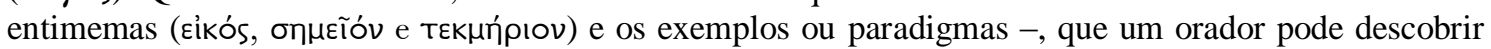
ou inventar, que se separam das técnicas não artísticas - uso das testemunhas, dos contratos, das leis, dos juramentos e das confissões obtidas mediante tortura -, que um orador pode usar, mas não pode inventar, pois são preexistentes. Estas últimas Tíoteıs, nas palavras de Aristóteles, são especialmente características da oratória forense.
} 
retórico do Eỉkós, ainda que sejam problemáticas, de algum modo, para o entendimento do sentido do termo no século $\mathrm{V}$ a.C. $\mathrm{O}$ tratamento dado ao Eikós na Retórica a Alexandre, por exemplo, divide-se em duas partes: na primeira, o autor apresenta a sua definição e subdivisão; na segunda, fornece exemplos do seu uso ${ }^{379}$. O importante, contudo, é a sua definição de eíkós em 1428 a27-32:

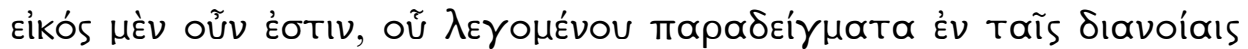

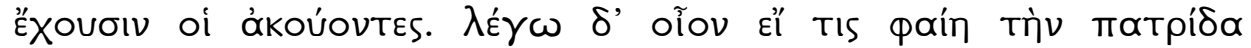

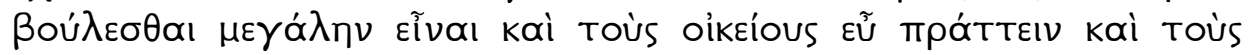

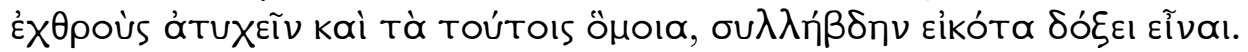

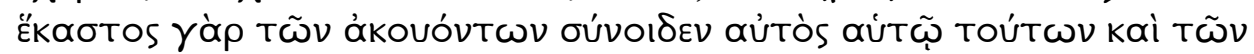

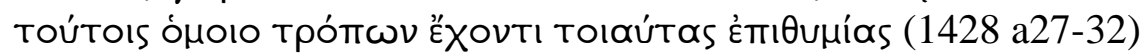

Um Eikós, então, ocorre quando membros de um auditório possuem exemplos em suas mentes do que está sendo dito. Digo, por exemplo, que se alguém declarasse desejar a glorificação de sua pátria, a prosperidade dos amigos e a desgraça dos inimigos - e coisas semelhantes a estas -, em geral suas declarações pareceriam plausíveis (Eíkóta), pois cada um dos ouvintes sabe que nutrem desejos semelhantes sobre esses assuntos e similares para si mesmos. $(1428 \mathrm{a} 27-32)^{380}$

Na Retórica, por sua vez, as referências ao kikós são breves. No livro I, em 1357

a35-b1, Aristóteles fornece sua concepção acerca dele:

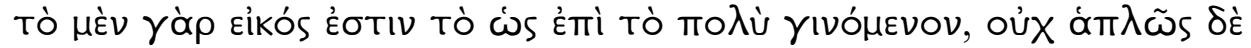

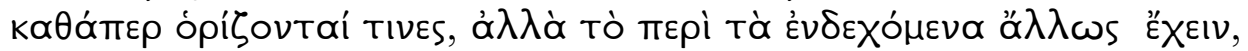

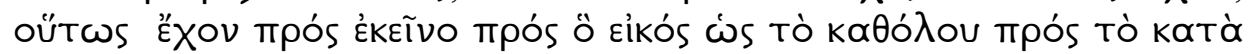
$\mu$ épos $^{\circ}$

\footnotetext{
${ }^{379}$ Atribuída a Anaxímenes de Lâmpsaco, a Retórica a Alexandre é um texto retórico provavelmente do século IV a.C. em que o autor, entre outras coisas, lida com o eỉós. Em seu sistema, o cíkós é o primeiro dos sete tipos de meios de persuasão (тíoteıร) que compõe um dos tópicos comuns a todas as espécies de oratória, não apenas a forense. As outras são "exemplos", "evidências", "entimemas", "máximas", "signos" e "refutações". Esses meios de persuasão têm sua fonte comum "nas palavras, ações e nas próprias pessoas" (1428 a17). O عíkós, particularmente, será dividido em três tipos. O primeiro consiste na inclusão em um discurso, quando se acusa ou se defende, do máđos (emoção), encontrado naturalmente nos seres humanos (1428 a36). Como explica Goebel, o autor desse tratado insiste na importância da experiência emocional comum em produzir credibilidade (GOEBEL, 1989, p.44), pois é bem conhecida do ouvinte. O exemplo referente ao máđos é citado em 1429 a15. Esse tipo de cíkós é menos um argumento do que uma afirmação que funcionará como um apelo emocional para os juízes, pois se trata de um conselho de Anaxímenes: uma vez considerado culpado pela acusação e sem haver a possibilidade de atenuar o fato pelo argumento segundo o qual muitos agem da mesma maneira, o acusado deverá se refugiar no "pretexto do infortúnio ou erro" (1429a15) tentando obter o perdão pelo apelo à emoção. Com

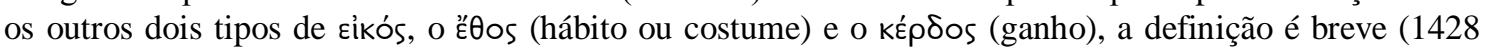
b8-11), mas os exemplos avançam pela seção seguinte. Um tipo diz respeito "àquilo que fazemos com base no costume"; o outro àquilo que fazemos pelo amor ao ganho, a ponto de "agir de uma maneira que violenta nossa natureza e nosso caráter".

${ }^{380}$ Tradução minha.
} 
"Com efeito, o Eíkós é o que geralmente acontece, mas não absolutamente, como alguns definem; antes versa sobre coisas que podem ser de outra maneira, e se relaciona no que concerne ao provável (Eikós) como o universal se relaciona com o particular". (1357 a35-b1) $)^{381}$

Pode-se observar que o Eikós mencionado na Retórica a Alexandre pressupõe, como afirma Goebel em Probability in the Earliest Rhetorical Theory (1989) ${ }^{382}$, um sentido mais social e pode ser definido em termos de seu efeito sobre a audiência e os exemplos oferecidos não são premissas gerais, mas afirmações particulares que têm o domínio sobre a crença porque correspondem à experiência emocional comum da audiência. Goebel sugere que, etimologicamente, o Eikós da Retórica a Alexandre comporta o sentido de "aquilo que parece (adequado)". Mas o termo poderia ser aplicado tanto para afirmações que possuem, segundo ele, a qualidade da verossimilitude psicológica, como para os argumentos que dependem de uma premissa geralmente aceita ${ }^{383}$. Na Retórica, por sua vez, Aristóteles restringe o termo sobretudo ao último caso, ou seja, à premissa geral, e pressupõe um sentido mais estático e quantificado; pressupõe certos padrões que regem o comportamento natural e humano (o que acontece conforme esses padrões é cíkós). Mas, inicialmente, o cíkós é definido em termos daquilo que ocorre na maior parte dos casos, podendo coincidir com uma opinião geralmente aceita. Na prática é o que pode ser baseado no que é meramente pensado ser verdade "para a maior parte". Na sequência, definido em termos aristotélicos, o eikós é uma afirmação geral que serve como premissa principal em um silogismo retórico. No livro II, em 1402 b14-16, no qual Aristóteles busca refutar esse argumento que ele julga falacioso, ele fornece a definição mais antiga. Segundo o filósofo, entimema (um silogismo em que se subentende uma premissa) baseado no Eíkós é aquele que, "as mais das vezes, é real ou parece sê-lo" (ARISTÓTELES, 1998, p. 172). Essa interpretação do eíkós de Aristóteles, contudo, é diferente do encontrado nos Primeiros Analíticos (70a3-10), definido como uma proposição que é, na maioria das vezes, aprovada ${ }^{384}$, e nesse sentido é aquilo que parece ser verdade para a maioria das

\footnotetext{
${ }^{381}$ Tradução de Manuel Alexandre Júnior, Paulo Farmhouse e Abel do Nascimento Pena (ARISTÓTELES, 1998, p. 53).

${ }^{382}$ GOEBEL, 1989, pp. 43-4.

${ }^{383}$ Ibid., p. 45.

${ }^{384}$ HOFFMAN, 2008, p. 7
} 
pessoas $^{385}$, aproximando-se das definições mais antigas e, sobretudo, da definição que Platão atribui a Tísias no Fedro 273b (“o Eikós é o que pensa a maioria”"386). Hoffman, no artigo Concerning Eikos: Social Expectation and Verisimilitude in Early Attic

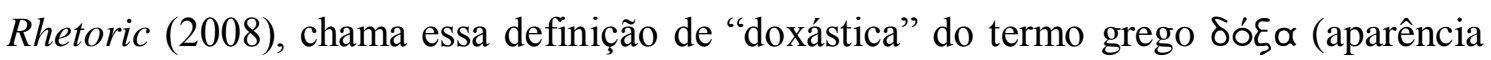
ou opinião): uma proposição é eikós quando parece ser adequada ou verdadeira para a maioria das pessoas ${ }^{387}$. Essa definição, contudo, é substituída por Platão por outra ainda no Fedro - e mantida no Timeu (29b-c) e no Sofista (235d-236c): cíkós é aquilo que é semelhante à verdade, ou seja, aquilo que é verossímil.

Em seu artigo, David C. Hoffman ressalta que a tradução do termo eikós por "provável" (bastante comum nas traduções para Aristóteles) seria, de certo modo, problemática, pois no século IV a.C. o Eikós diferiria da noção moderna de provável relacionada a um conceito matemático então desconhecido dos gregos antigos ${ }^{388}$. A partir de um sentido mais antigo de Ěoık $\alpha$ como "ser similar", e de palavras gregas com uma relação etimológica mais próxima, como o verbo eỉká $\zeta \omega$, cujo significado é

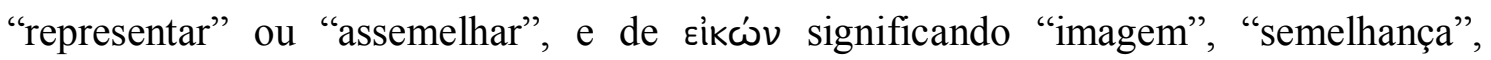
"similitude", Hoffman propõe um sentido duplo de eỉkós (particípio perfeito neutro de Éoık ), como aquilo que é socialmente adequado ou esperado (a expectativa social que é a definição "doxástica") e como aquilo que é semelhante ao verdadeiro ou que tem qualidade de verossimilhança. Segundo ele, esses dois significados teriam sido de grande importância para a oratória ática do século $\mathrm{V}$ a.C. e ambos operavam conjuntamente na estratégia de emoldurar alguns argumentos do zíkós ${ }^{389}$. Essa dupla definição pareceria bastante adequada para o sentido do termo na Tetralogia I.

Considerado um importante componente para a retórica grega, acredita-se que o argumento do eikós tenha sido, na primeira metade do século V a.C., um dos interesses

\footnotetext{
${ }^{385}$ Kennedy cita a frase "Crianças amam seus pais", retirada da obra Primeiros Analíticos (70a3-70a23), como um exemplo de Eikós que é uma observação geral (uma premissa principal) - universal na forma e provável, mas não necessariamente verdadeira em um sentido particular. (ARISTOTLE, 2007, p. 42).

${ }^{386}$ Tradução minha.

${ }^{387}$ HOFFMAN, 2008, p. 7

${ }^{388}$ Segundo Hoffman (pp. 05-6), a concepção moderna de probabilidade remete ao século XVII d.C. As probabilidades matemáticas teriam sido desenvolvidas pelos matemáticos indianos e árabes e transmitidos, juntamente com os em umerais arábicos, para o Ocidente. Desse modo, o conceito grego de Eikós diferiria de nosso entendimento de probabilidade baseado na frequência, pois faltaria aos gregos a noção dos em umerais para chegar a esse conceito moderno, algo como uma declaração de que alguma coisa é cikós quando ocorre mais do que cinco vezes entre dez. Aristóteles, no entanto, teria se aproximado dessa concepção baseada na frequência em sua definição fornecida na Retórica. Ainda assim, não se trata do conceito matemático moderno. E, ao que parece, outros pensadores do período não teriam compartilhado dessa concepção aristotélica.

${ }^{389}$ HOFFMAN, 2008, p. 3
} 
de Córax e/ou Tísias ${ }^{390}$, a quem a tradição atribui a invenção da retórica ${ }^{391}$. A narrativa da "invenção", que confere a ambos a primeira composição de um manual de retórica voltado a ensinar como produzir discursos persuasivos é motivo de controvérsias ${ }^{392}$. Quase nada sobreviveu desses ensinos. Alguns autores modernos, no entanto, sugerem que o que se considera um "manual" de retórica consistia, na realidade, de um conjunto de exemplos ou discursos-modelos transmitidos oralmente, e que tratados organizados sobre preceitos analíticos (tais como a Retórica de Aristóteles e a Retórica a Alexandre) seriam desenvolvidos apenas posteriormente ${ }^{393}$. O que Tísias e/ou Córax talvez tenham composto tenha sido uma coleção de modelos de discursos análoga às encontradas nas Tetralogias e que traria versões resumidas de alegações a favor e contra acerca de algum assunto, possivelmente para uso em processos judiciais e que, ao menos alguns desses assuntos, eram baseados no princípio do eíkós ${ }^{394}$. Não seria possível, contudo, creditar a Tísias e/ou Córax a invenção do argumento do Eíkós, visto que o emprego de tal argumento os precede.

É possível que o exemplo mais antigo conhecido do uso do عíkós esteja em uma passagem do Hino a Hermes ${ }^{395}$. É exatamente nesse texto que Hoffman ${ }^{396}$ sugere que está presente o seu sentido mais antigo ("̌oıka como "ser similar") e que outros sentidos são extensão desse sentido principal. A data desse hino, contudo, é incerta,

\footnotetext{
${ }^{390}$ Thomas Cole, em Who was Corax? (1991), em linhas gerais sugere que, a partir de fontes antigas, não haveria evidência para afirmar que Córax tenha, de fato, existido. Córax ("corvo", em grego) possivelmente teria sido um apelido pejorativo de Tísias.

${ }^{391}$ Segundo a tradição, dentre as principais contribuições de um suposto manual técnico criado por Córax e Tísias na Sicília em torno de 467 a.C. estariam incluídas discussões acerca da elocução, a indicação das partes do discurso forense e o argumento do eikós.

${ }^{392}$ Cf. COLE, T. The Origins of Rhetoric in Ancient Greece (1991) e SCHIAPPA, E. The beginnings of Rhetorical Theory in Classical Greece (1999).

${ }^{393}$ Schiappa, sobretudo, busca revisar os relatos tradicionais acerca dos antigos sofistas e da teorização grega antiga a respeito da teoria retórica a partir das afirmações de Kennedy em suas obras Classical Rhetoric an Its Christian and Secular Tradition from Ancient to Modern Times (1980) e The Art of Persuasion in Greece (1963). A obra de Shiappa, The beginnings of Rhetorical Theory in Classical Greece (1999), centra-se na tese de que, a partir da leitura cuidadosa de textos e fragmentos do século V a.C., não haveria evidência para sugerir que alguma coisa como uma análise sistemática do discursar em público tenha ocorrido no período; que seria equivocada a tendência de se interpretar tais textos e fragmentos através da utilização de uma palavra (’́クтopıкń) desenvolvida apenas posteriormente, e que se atribui a uma prática do século V a.C. um status de disciplina; que os chamados "manuais" antigos consistiam principalmente de exemplos e que tratados voltados para preceitos técnicos, como os encontrados na Retórica de Aristóteles e na Retórica a Alexandre, seriam desenvolvidos mais tarde; e que, diante de evidências pouco confiáveis, o relato padrão da "invenção" da retórica por Córax e Tísias é bastante questionável, tratando-se possivelmente de uma lenda.

${ }^{394}$ GAGARIN, 2007, p. 30-1

${ }^{395}$ Os hinos homéricos são compostos de trinta e quatro hinos, dentre os quais o Hino a Hermes. Na antiguidade foram atribuídos a Homero, mas provavelmente são composições de autores diferentes, de lugares diferentes e de épocas diferentes. (FAULKNER, 2011, p. 1)

${ }^{396}$ HOFFMAN, 2008, p. 10
} 
possivelmente entre 500 e 450 a.C., ou mesmo mais antiga ${ }^{397}$. A passagem em questão encontra-se logo após Apolo acusar Hermes de roubar seus bois (vv. 254-259). O filho de Leto, então, recebe de Hermes como resposta o argumento segundo o qual, por ele ser muito jovem - Hermes é apenas uma criança (maĩs) - não é razoável ou plausível

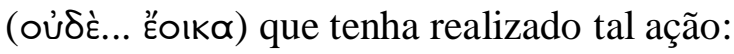

"Filho de Leto, que fala rude é essa que proferiste? E foi em busca de bois agrestes que até aqui vieste? Não vi, não sei de nada e não ouvi palavra de outrem; não poderia dar indicações nem mesmo aceitar recompensa; nem de tocador de bois, gente vigorosa, eu tenho o aspecto ('̌oık $\alpha)$ ! Meu afazer não é esse; antes, outras coisas me importam: importa-me o sono, o leite de minha mãe, ter fraldas ao redor dos ombros e banhos quentes. Que ninguém fique sabendo como surgiu essa desavença! Causaria mesmo um grande espanto entre os imortais um menino recém-nascido ( $\pi \propto \tilde{I} \delta \propto$ vÉov $\gamma \varepsilon \gamma \propto \tilde{\omega} \tau \alpha$ ) transpor o vestíbulo com bois agrestes! É descabido o que declaras!

Nasci ontem, tenho pés mimosos e sob eles o chão é áspero!

Se queres, pela cabeça do meu pai farei o grande juramento:

Dou minha palavra de que não sou eu o responsável, nem mesmo vi um outro ladrão de vossas vacas, quais sejam tais vacas. Apenas ouço tal rumor!'(vv. 261-277) ${ }^{398}$

Como explica Thomas Schmitz, no artigo Plausibility in the Greek Orators $(2000)^{399}$, um detalhe importante nessa passagem é que Hermes está mentindo. Sabemos que, de fato, a criança roubou os bois de Apolo, contrariando, segundo o autor, todas as

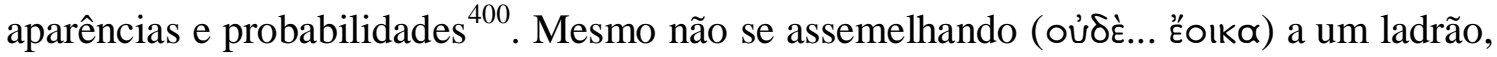
Hermes agiu como um.

É interessante notar que o cenário criado é, em algum sentido, o de um tribunal, com Apolo e Hermes levando sua disputa a Zeus, que atua como juiz, examinando o caso diante de uma assembleia de deuses, que, por sua vez, apenas assiste sem interferir no caso. Na opinião de Kennedy ${ }^{401}$, que leva em conta a antiguidade do poema (século VI a.C.), a cena narrada no hino seria a mais antiga na literatura grega a se aproximar de uma corte de tribunal. Gagarin também vê na cena um cenário praticamente legal, no

\footnotetext{
${ }^{397}$ Faulkner menciona a possibilidade de uma datação anterior ao século VI a.C., mas seria pouco provável, sendo talvez uma composição da metade do seculo V a.C. (FAULKNER, 2011, pp. 12-3)

${ }^{398}$ Tradução de Maria Celeste C. Dezotti (HINOS HOMÉRICOS, 2010, pp. 406-55).

${ }^{399}$ SCHMITZ, 2007, p. 49

400 Ibid., p. 49.

${ }^{401}$ KENNEDY, 1963, p. 40
} 
sentido de os litigantes submeterem a disputa a uma autoridade superior (Zeus) e em um ambiente público mais formal (a assembleia dos deuses) ${ }^{402}$.

Em sua análise sobre o hino, Schmitz ${ }^{403}$ acredita que o seu autor não somente estava familiarizado com o uso retórico do Eíkós, como estava ciente de que podia empregá-lo enganosamente; que fosse um procedimento útil para a trapaça. Essa forma particular de argumento, afirma Schmitz ${ }^{404}$, poderia bem ser uma paródia jocosa de estratagemas que o autor do hino talvez considerasse típicos de discursos de tribunal. Independentemente disso, essa passagem pressupõe que seu uso já era conhecido no período da composição do hino. Com efeito, ao ser empregado nos discursos de Antifonte (Tetralogias I e III; Antifonte 5.25-28), considerado o mais antigo dos oradores áticos, algumas décadas depois, o uso do عíkós - seu procedimento provavelmente já seria bastante praticado.

Convém lembrar que, além do Hino a Hermes, o discurso de Parsifal na obra perdida Cretense de Eurípides, datada de 430 a.C., é tido como o exemplo explícito mais antigo na tragédia do uso do Eikós. No Édipo Rei (v. 583), provavelmente composto em 429 a.C., Sófocles, apesar de não mencionar o termo, usa o argumento do Eíkós. Nota-se também a presença de tal argumento nas Histórias de Heródoto no livro 3 (3.38.2). Nesses textos, o sentido também parece ser daquilo que é "adequado", "plausível”, "razoável” ou "esperado".

Hoffman ${ }^{405}$, contudo, alerta para a dificuldade de se traçar as origens dos argumentos do eikós e para o fato de que fontes antigas não fornecem indícios claros sobre quem os utilizou inicialmente. Um dado importante é que, dos textos ou informações que chegaram até nós com referências ao uso retórico do eíkós, credita-se a Tísias e/ou Córax um avanço importante: o desenvolvimento de uma nova forma de argumentação que consiste exatamente em uma contra-argumentação do eíkós, o que Gagarin chama de "inversão do argumento da probabilidade" (reverse probability argument ${ }^{406}$. Ele é retratado no clássico exemplo da luta entre um homem fraco e um homem forte. De acordo com esse exemplo, um homem fraco sustenta que não é razoável (ou plausível) que ele, em razão de sua fraqueza, tenha agredido um homem

\footnotetext{
${ }^{402}$ GAGARIN, 1986, p. 41

${ }^{403}$ SCHMITZ, 2007, p. 49.

${ }^{404}$ Ibid., p. 49.

${ }^{405}$ HOFFMAN, 2008, p. 2

${ }^{406}$ GAGARIN, 1994. p. 51
} 
forte. Este, por sua vez, contesta essa alegação revertendo o argumento do Eikós: não é razoável (ou plausível) que ele, um homem forte, tenha agredido um homem fraco, uma vez que a suspeita do crime imediatamente recairia sobre ele. Esse exemplo é fornecido por Aristóteles no livro II da Retórica como ilustrando um dos tópicos tratados por Córax - nada é mencionado sobre Tísias. O filósofo o transmite da seguinte maneira:

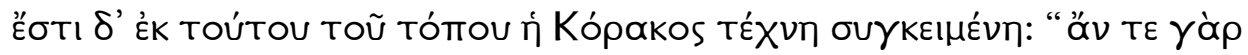

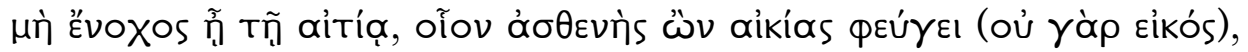

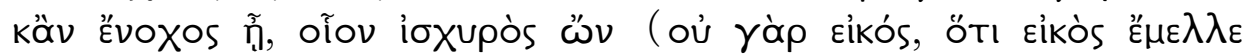

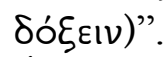

É deste tópico [do عíkós] que se compõe a "Arte" de Córax: se um homem não dá pretexto a uma acusação, por exemplo, se, sendo fraco, for acusado de violência (porque não é provável); mas se der azo a uma acusação, por exemplo, se for forte (dir-se-á que não é provável, justamente porque ia parecer provável). (Retórica, II, 1402 a18-21) 407 $^{40}$

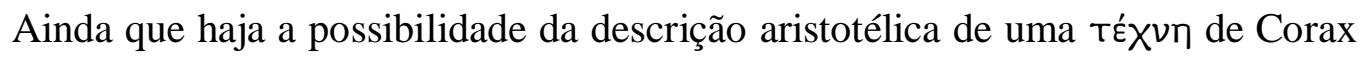
ser, como sugere Schiappa, anacrônica ${ }^{408}$, e que a referência a uma teoria antiga do દíkós seja antes baseada em uma anedota transmitida oralmente a respeito da defesa de um homem fraco e de um homem forte ${ }^{409}$, do que parte de um conjunto de exemplos e discursos-modelos, interessa-nos observar, contudo, o procedimento da argumentação e, aqui especificamente, da contra-argumentação do eíkós. No mais, o sentido do દíkós encontrado nesse exemplo parece remeter a um dos sentidos mencionados por Hoffman: daquilo que é socialmente adequado ou esperado.

A exposição do tratamento de uma argumentação baseada no eíkós também pode ser notada no Fedro de Platão, escrito por volta de 365 a.C. e a referência mais antiga, de que se tem notícia, a Tísias - nada é mencionado sobre Córax. É possível que Platão esteja se referindo ao mesmo exemplo citado por Aristóteles, mas adaptando os detalhes de acordo com seus propósitos. Na exposição platônica, novamente explicita-se o interesse do(s) autor(s) siciliano(s) pelo uso retórico do eíkós e seu desenvolvimento do ponto de vista argumentativo. Em um determinado momento do diálogo, tendo Sócrates

\footnotetext{
${ }^{407}$ Tradução de Manuel Alexandre Júnior, Paulo Farmhouse e Abel do Nascimento Pena (ARISTÓTELES, 1998, p. 171).

${ }^{408}$ Schiappa baseia-se no tratamento de Aristóteles dispensado aos filósofos pré-socráticos e às doutrinas dos sofistas que demonstraria uma inclinação em reescrever a história tendo em vista seu próprio sistema filosófico - em sua própria visão, superior ética, etimológica e ontologicamente -, para acreditar que é bastante plausível que a descrição da TÉxvn de Córax feita por Aristóteles seja anacrônica. (SCHIAPPA, 1999, p. 38)

${ }^{409}$ SCHIAPPA, 1999, p.39
} 
afirmado que Tísias e Górgias haviam compreendido que os Eikóta são mais dignos de

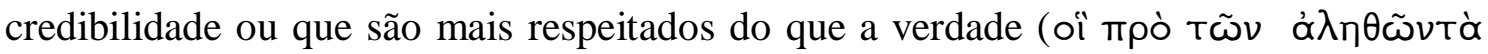

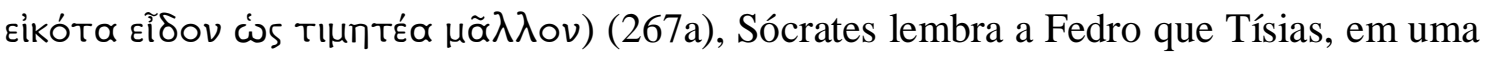

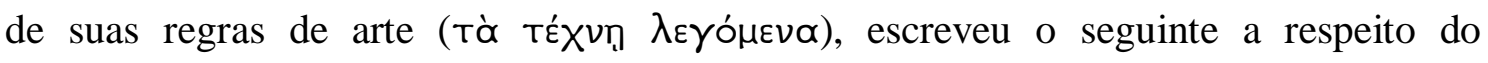
assunto $^{410}$ :

\section{$[273 \mathrm{~b}](\ldots)$}

\section{$\Sigma \omega$ Kpótins}

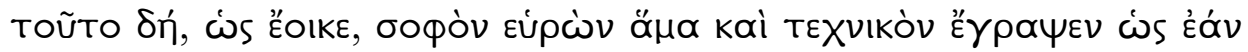

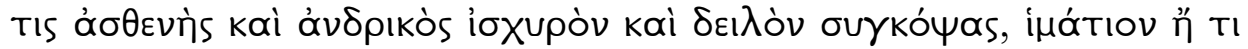

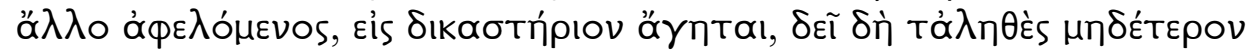

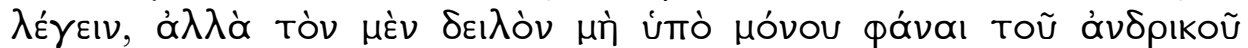

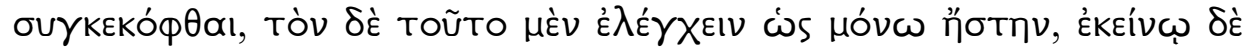

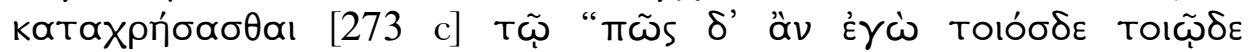

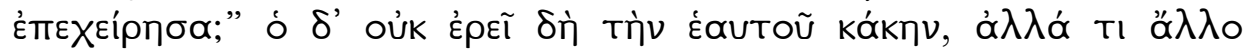

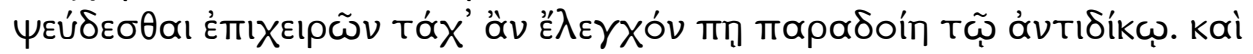

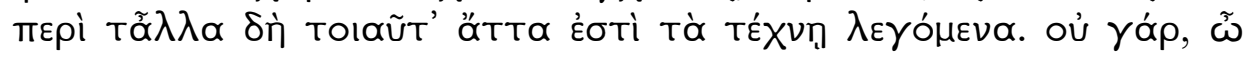
Фат̃ठрє;

\section{$[273 \mathrm{~b}](\ldots)$}

\section{Sócrates}

"Ao que parece, depois que ele (Tísias) concebeu esse argumento ${ }^{411}$, ao mesmo tempo sábio e técnico, ele escreveu que se um homem fraco fisicamente e corajoso, depois de atacar um outro, forte fisicamente e covarde, e, tendo lhe roubado a roupa ou alguma outra coisa, for levado ao tribunal, não convém a nenhuma das partes falar a verdade (Tả $\lambda \eta \theta \dot{s}$ $\lambda \varepsilon ́ \gamma \varepsilon ı \nu)$, mas ao covarde convém falar que não foi atacado por um único homem; enquanto ao outro convém provar que só os dois estariam presentes, e contra aquele bastaria o seguinte argumento: [273c] 'Como eu teria atacado um homem como esse?'. O covarde não falará de sua própria covardia, mas tentará contar alguma outra mentira, que poderia talvez entregar a seu adversário um argumento refutatório. Também a

\footnotetext{
${ }^{410}$ Ainda que a personagem Sócrates mencione que o argumento do eỉós é uma regra da arte de Tísias, ele mesmo, em seguida, coloca em dúvida se ela "foi descoberta por Tísias, ou por algum outro (...)" (273c). (Tradução minha)

${ }^{411}$ Que o cíkós é o que pensa a maioria das pessoas (273b). Essa afirmação remete ao que Sócrates havia reportado anteriormente (272d), que, segundo aqueles que se consideram autoridades em oratória, não parece ser condição necessária para ser um bom orador o conhecimento do que é bom e justo, pois nos tribunais ninguém está preocupado com a verdade sobre assuntos fundamentais, mas apenas com o que é plausível (тоũ mı® acusação, quer na defesa, deve se ater ao que é plausível (Eikós) e deixar de lado o que realmente aconteceu (272e). Essa, concluem Sócrates e Fedro, é a regra básica daqueles que se dedicam à arte de fazer discursos. Portanto, os fatos do caso não são algo mais a serem respeitados, na medida em que só se deve dizer o que parece ser verdadeiro (272e) e não a verdade em si. Vale lembrar que, nessa passagem, Sócrates está ironizando algumas técnicas retóricas de alguns oradores individuais, entre eles Tísias e Górgias que "descobriram que os Eikóta ("suposições razoáveis" ou "verossimilhanças") são mais respeitados que a verdade" (267 a).
} 
respeito de outros assuntos existem algumas outras regras de arte. Não é assim, Fedro?"412 (Platão, Fedro, 273 b-c)

Ainda que o assunto do uso retórico do Eikós seja abordado por Platão por um viés claramente negativo, e ainda que não seja possível afirmar que Tísias escreveu

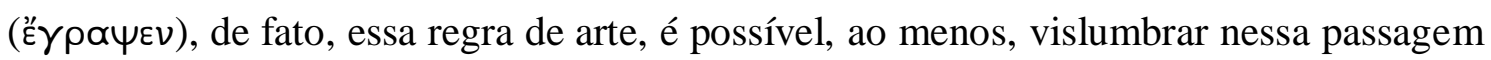
como se daria uma estratégia baseada nos argumentos do Eikós que, em uma situação específica de tribunal, cada um dos litigantes poderia utilizar. Um possível argumento fornecido pelo homem fraco e corajoso se basearia no fato de que não seria plausível ("razoável”, "verossímil”) que ele, por causa de seu aspecto físico, atacasse um homem forte. Embora o argumento pressuponha que a expectativa razoável, tendo em vista o comportamento humano comum, seria a de que ele não o fizesse, o termo é empregado por Platão - e nisso consiste a sua crítica - como um contraponto à verdade: é aquilo que parece ser verdadeiro ou semelhante à verdade, mas não é a verdade em si (272e). Desse modo, o sentido de Eíkós parece fazer referência àquilo que é semelhante ao verdadeiro ou que tem qualidade de verossimilhança. Ao contrário do exemplo aristotélico, no platônico o sentido de semelhante à verdade é explicitado, pois as partes ocultam a verdade sobre si mesmas.

Com relação à Tetralogia I, ainda que o uso do eíkós já fosse conhecido e talvez já estivesse completamente desenvolvido no período em que Antifonte a compôs (ca.430 a.C.), pode-se afirmar que, dos textos que chegaram até nós, ela é aquele que melhor ilustra não somente o uso argumentativo do eikós como também se articula com a anedota creditada aos autores sicilianos. A Tetralogia I reproduziria de modo exemplar o procedimento da argumentação e da contra-argumentação baseada no Eikós, e, acima de tudo, forneceria uma análise desse argumento em sua relação com os fatos ou com a verdade.

No texto, a questão é colocada logo após a acusação, no início de seu discurso, observar que é difícil desmascarar e incriminar uma pessoa quando ela é inteligente e tem tempo para planejar e executar um crime (2.1.1-2). Diante de um oponente inteligente e de uma situação em que os fatos são obscuros, ela pede para os juízes confiarem seu julgamento nos argumentos, mesmo que estes sejam baseados unicamente no eỉkós, ou seja, naquilo que é plausível ou razoável (2.1.2).

${ }^{412}$ Tradução minha. 
De imediato, como observa Gagarin ${ }^{413}$, fica evidente que o uso do argumento do Eikós é uma necessidade, não uma escolha, visto que um conhecimento claro não é possível em um caso como esse. Por essa perspectiva, e o restante da Tetralogia I indicará isso, pode-se dizer que Antifonte não apenas está interessado em explorar o argumento do eikós, mas, sobretudo, em considerar as circunstâncias em que ele pode ser utilizado e sua validade com relação a outros tipos de $\operatorname{argumentos}^{414}$, algo que a Tetralogia III, por exemplo, ilustrará bem, ao expor prontamente a fraqueza de tal argumento na presença da evidência direta.

Na sequência do discurso, os acusadores, possivelmente parentes ou amigos da

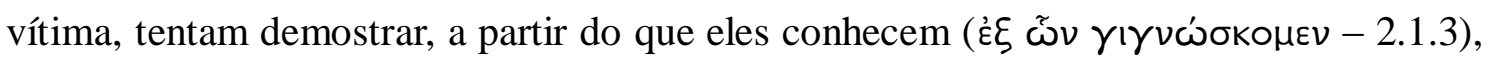
que o réu é o assassino. Para isso, servem-se do eikós para eliminar outros possíveis suspeitos ou explicações razoáveis para o homicídio (2.1.4). Empregando uma argumentação chamada "apagógica”, usada por Górgias em Elogio de Helena (6) e em Defesa de Palamedes (6-12), pelo qual um orador eem umera uma série de possibilidades para depois rejeitá-las ${ }^{415}$, a acusação deduz que não foram assaltantes, pois nada foi roubado das vítimas; não foi um homem embriagado, pois seria reconhecido por seus companheiros de bebida; não foi alguém durante uma briga, pois uma briga não aconteceria no meio da noite e em lugar deserto; e não foi alguém que, acidentalmente, confundiu a vítima com outra pessoa, pois não teria matado também o escravo. Diante da eliminação de outras alternativas plausíveis ou razoáveis para o crime, a acusação reforça a premeditação da morte e, com base no Eikós, define que o réu é o responsável, pois se trata do principal inimigo da vítima e que teria inúmeras razões para matá-la (2.1.5-8). Mesmo que Antifonte não desenvolva uma narrativa, uma mínima noção dos fatos pode ser deduzida dessa argumentação central da acusação: o homem e o escravo foram mortos "em uma hora avançada da noite e em lugar deserto" (2.1.4) e, tudo indica, após saírem de algum lugar de onde bebiam.

\footnotetext{
${ }^{413}$ GAGARIN, 2002, p. 113

${ }^{414}$ Ibid., p. 113.

${ }^{415}$ Em Elogio de Helena (6), por exemplo, Górgias propõe as possíveis causas para a ida de Helena para Troia e sugere que ela deve ter cedido a Páris por uma destas quatro causas: pela vontade dos deuses; ou pela força; ou persuadida por palavras; ou capturada pelo amor. Cada uma dessas possíveis causas é examinada uma após a outra e, ao final, demonstra-se que, em cada caso, Helena não pode ser responsável por sua ação. Em Defesa de Palamedes, o método é empregado por Górgias durante a exposição do herói acerca de seus motivos para não ter traído a Grécia (13-21): uma pessoa comete um crime ou para obter um ganho ou para evitar a perda. Antes disso, algumas ações empreendidas para a realização da traição são consideradas pelo herói para, na sequência, serem reveladas como impossíveis de terem sido realizadas (6-12). Em sua totalidade, a argumentação de Palamedes se baseará no raciocínio de que se ele tivesse cometido traição teria sofrido os resultados opostos.
} 
A acusação, então, adiciona uma suposta evidência do testemunho do escravo. De acordo com ela, "se estivessem presentes muitas testemunhas, muitas nós teríamos apresentado; visto que apenas uma estava presente, o escravo, aqueles que o ouviram testemunharão" (2.1.9). A questão é que o escravo não pode ser trazido ao tribunal para testemunhar, pois está morto. Aqueles que encontraram o escravo aparentemente ainda vivo reportarão o que supostamente o escravo testemunhou. Fica evidente, já nesse primeiro momento, que o testemunho reportado do escravo é uma míotis questionável. E, como Gagarin ${ }^{416}$ sugere, a acusação está ciente disso, pois dedica um espaço muito maior aos motivos que levaram o acusado a cometer o crime e apenas uma rápida menção ao testemunho. Isso pressupõe que essa evidência possui um peso na argumentação menor do que os argumentos baseados no Eikós. Mesmo assim, os acusadores agregam uma evidência problemática do escravo a uma evidência indireta (o Eíkós) - vistos, pelos acusadores, como os únicos meios diante da ausência de uma evidência mais clara - para declararem o réu culpado pelo crime (2.1.9).

A defesa, por sua vez, começa seu discurso lamentando não apenas o fato de ter que provar sua inocência, como também de ter que encontrar o assassino, algo de que os acusadores são incapazes de fazer (2.2.2). A partir disso, busca reverter os argumentos do Eikós da acusação alegando que, visto que as circunstâncias (sua grande inimizade com o morto) tornam a suspeita contra si tão evidente, não praticou o homicídio, pois o mais razoável (عíkótepov) nessa situação é que, antes de praticá-lo, teria previsto que essa suspeita tão evidente recairia imediatamente sobre si (2.2.3). E mais, dadas as circunstâncias que não lhe são favoráveis, alega, sobretudo, que teria impedido o crime se soubesse que algum outro tramava contra a vítima (2.2.3). A defesa, contudo, diante de uma acusação que ela considera equivocada, pois é inocente e não praticou o crime, ressalta que não há outra forma de provar sua inocência senão pelos mesmos meios empregados pelos acusadores, ou seja, pelo eikós. Seu raciocínio é o de que, se ela é considerada culpada pelos acusadores apenas porque ela é a principal inimiga da vítima e porque não é razoável que outros tenham praticado o homicídio, se for razoável que algum outro o tenha praticado, sua inocência poderia ser provada (2.2.4). Desse modo, rebatendo os argumentos baseados no eikós do discurso anterior, elenca algumas alternativas possíveis para o relato da acusação (2.2.5-6): porque alguém se aproximou, os assaltantes não puderam roubar as vítimas; estas foram mortas porque 
testemunharam outro crime. Mas, acima de tudo, a defesa contra-argumenta a alternativa principal da acusação (2.1.5-8), ressaltando que poderia haver muitos outros inimigos, não apenas um, e estes poderiam ter motivos para matar o homem, ainda que suas motivações fossem mais fracas; além do mais, a execução do homicídio seria facilitada pois as maiores suspeitas não recairiam sobre eles. A isso adiciona, baseandose também no Eíkós, que o testemunho do escravo não pode ser confiável, primeiro, porque, "aterrorizado pelo perigo", possivelmente o escravo não teria reconhecido os assassinos; segundo, porque teria sido "induzido pelos seus senhores", no caso, os amigos e/ou parentes do morto, a dizer o que eles o forçassem a dizer (2.2.7). Logo, o escravo não poderia saber nem falar a verdade.

Ao lidar com a evidência questionável do testemunho do escravo, a defesa atenta para o fato de que os juízes não agiriam com justiça se o condenassem à morte acreditando em tal testemunho, pois se fossem confiáveis, diz ela, os escravos não

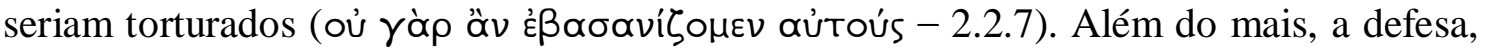
nessa passagem, é bem clara ao questionar o uso do testemunho dos escravos em geral,

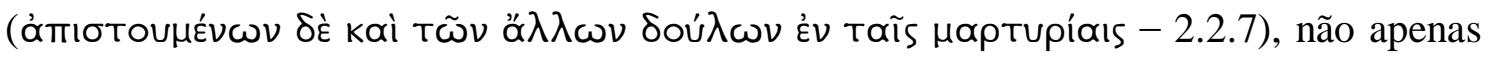
neste caso específico.

Uma discussão interessante sobre a confissão mediante tortura (ßর́ơ vos), ou seja, a evidência do escravo, é apresentada por Aristóteles na Retórica ${ }^{417}$. Após indicá-la

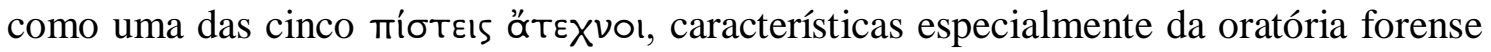
(1375a23-1377b13), Aristóteles comenta em 1376b32-1377a7 que se trata de um tipo de testemunho e parece ter credibilidade pois as confissões resultam de uma coação. No que concerne ao seu emprego, Aristóteles diz que se ele for vantajoso para um litigante, convém a ele aumentar seu valor declarando que são os únicos testemunhos verídicos de que se dispõe; mas se lhe for desvantajoso e vantajoso para seu oponente, ele pode refutá-lo condenando a ideia geral da confissão sob tortura, declarando que qualquer um (escravo) que seja submetido à tortura expressa tanto o falso quanto o verdadeiro, pois enquanto uns esforçam-se em não dizer a verdade, outros mentem facilmente na esperança de encerrar a punição mais rapidamente. Essas duas perspectivas apontadas pelo filósofo parecem se adequar às da acusação e da defesa nessa Tetralogia I, pois, para a primeira, é uma vantagem o seu emprego e, ainda que seja questionável o testemunho de um escravo morto, seu valor é aumentado e tratado como um testemunho

${ }^{417}$ Cf. também Retórica a Alexandre (1432a13-a32). 
verídico; enquanto para a segunda, é uma desvantagem e seu valor é diminuído, pois, para ela, o escravo, não sendo imparcial, diria o que seus senhores desejassem e não a verdade.

A defesa, por fim, prossegue rebatendo o discurso da acusação ao fornecer uma situação plausível, segundo ela, caso premeditasse o homicídio (2.2.8), mas refuta-a em seguida, ao apontar as implicações para ele e para seus filhos de uma condenação à morte (2.2.9). Chama a atenção, no entanto, uma declaração do réu: se a acusação considera os Eíkóta (o que parece como verdade ou o que é verossímil) semelhantes à

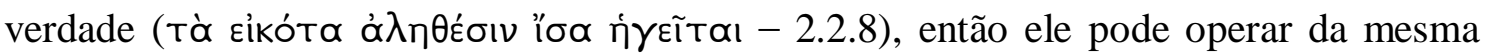
maneira e considerar que eles lhes são favoráveis ${ }^{418}$. A afirmação do réu, como nota Gagarin $^{419}$, não parece insinuar uma superioridade do eíkós, mas exatamente o contrário: implica que a verdade factual é normalmente primordial, mas que, para o réu, o acusador incorretamente insinua que o Eikós poderia ser igualado à verdade. $\mathrm{Na}$ sequência dessa declaração, outra, igualmente importante, distingue aquilo que é

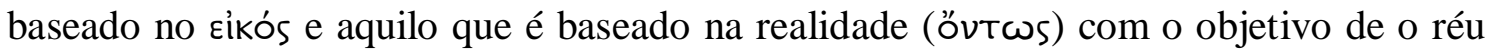
obter a absolvição: "É muito mais justo que eu seja absolvido por vocês, ainda que, de

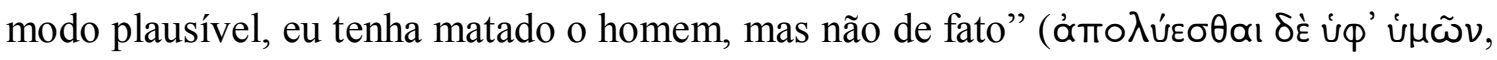

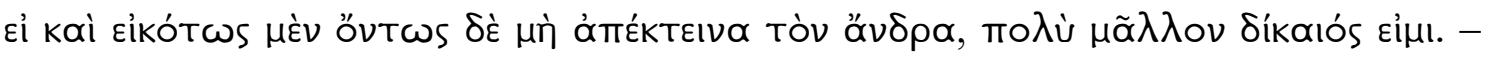
2.2.10). Novamente o argumento do Eíkós é tratado como uma necessidade, não como uma escolha, pois seria desnecessário se fosse possível conhecer o que aconteceu. Em nenhum momento declara-se que a verdade factual é inferior ao Eíkós. A essas declarações, o réu adiciona um argumento final que consiste em elencar seus serviços prestados anteriormente à cidade e aspectos positivos de sua conduta como um bom motivo para ser absolvido (2.2.12).

Em seu último discurso, a acusação dedica-se, sobretudo, a reverter os argumentos do zíkós do discurso da defesa, que, por sua vez, tinha rebatido os da acusação. Para isso, começa contra-argumentando as alternativas plausíveis para o

\footnotetext{
${ }^{418}$ A maneira válida encontrada por Aristóteles, por exemplo, de refutar um argumento do eíkós é mostrar que, de fato, não se trata de uma suposição razoável. "Uma vez que o provável [Eikós] não é o que sempre se produz, mas sim a maioria das vezes" (ARISTÓTELES, 1998, p. 172), este entimema pode ser refutado ao se fornecer uma objeção ou contra proposição. Para Aristóteles, trata-se de uma refutação aparente, "nem sempre verdadeira, uma vez que para o proponente não se trata de refutar que tal coisa é razoável que aconteça, mas de provar que não é necessária" (Ibid., p. 173). A vantagem, diz Aristóteles, é daquele que defende, não daquele que acusa, por causa justamente dessa falácia. Assim, qualquer argumento fundado no que ocorre usualmente ou costumeiramente mostra-se vulnerável à objeção.

${ }^{419}$ GAGARIN, 1994, p. 53.
} 
homicídio sugeridas pelo réu (2.3.2-3) e suas motivações (2.3.5-6): o escravo moribundo nada mencionou sobre assaltantes; nenhum outro crime foi anunciado a não ser o contra as vítimas; os riscos corridos pelos outros inimigos seriam maiores do que os sofridos pelo réu; ter estado presente ou ausente no momento do crime não prova nada dadas as suas motivações para praticá-lo; a acusação de roubo não seria descartada e não haveria um acordo com a vítima fora do tribunal. $\mathrm{A}$ isso, é adicionado que o testemunho do escravo é confiável, "pois em situações de tais testemunhos, eles não são submetidos a tortura, mas são deixados livres" (2.3.4). Alguns comentadores explicam que havia a possibilidade, em alguns casos, de que os escravos fossem interrogados sem serem submetidos à tortura, mas com um procedimento e um interrogatório oficial ${ }^{420}$, e que poderiam obter a liberdade caso dessem informações sobre um crime sério ${ }^{421}$. Talvez não houvesse uma lei para isso, como nota Gagarin, mas fosse uma prática comum $^{422}$. Além do mais, a crença da acusação no testemunho do escravo se justifica porque lhe é vantajoso. Por isso, é natural que declare que os escravos "dizem a verdade quando torturados" (2.3.4), ao contrário do declarado pela defesa, para quem, se os escravos fossem confiáveis, não seriam torturados (2.2.7), prova da falta de confiança com relação aos testemunhos deles.

A acusação, então, contesta a inversão do argumento do Eiḱós da defesa quanto à observação de que, como as circunstâncias (a grande inimizade do réu com o morto) tornam a suspeita contra o réu tão evidente, não deveria ser considerado culpado, pois o mais razoável (દikótepov) nessa situação é que, antes de praticar o homicídio, teria previsto que essa suspeita tão evidente recairia imediatamente sobre ele (2.2.3). A acusação alega que esse raciocínio, além de incorreto, conduziria a uma lógica absurda de que ninguém teria matado a vítima, pois, como explica Gagarin ${ }^{423}$, um motivo forte ou fraco para matar faria de uma pessoa um suspeito plausível ou implausível na mesma medida, e essa plausibilidade ou implausibilidade seria, então, um motivo igualmente forte ou fraco para demovê-lo da ação de matar (2.3.7). Essa lógica é rebatida pelo acusador com a declaração simples de que, por ser o principal suspeito, o réu deve ser o culpado: na ausência de assassinos, pois não foram revelados até o momento (2.3.8), e de outra evidência mais contundente, o réu, "considerado culpado pelas plausibilidades

\footnotetext{
${ }^{420}$ ANTIPHONTIS, 1969, pp. 196-97.

${ }^{421}$ Cf. Antifonte 5.34

422 ANTIPHON, 1997, p. 137

${ }^{423}$ GAGARIN, 2002, p. 114
} 


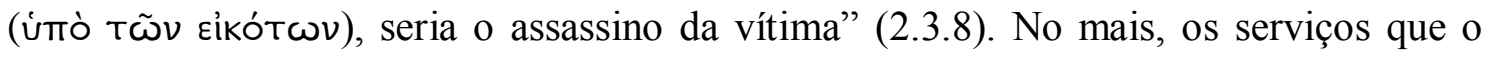
acusado prestou à cidade são indicativos apenas de sua riqueza, não de sua inocência (2.3.8).

Por fim, a réplica do acusado começa com a ressalva de que ele não partiu para o exílio, aquilo que, de fato, é um procedimento consentido por lei. Declarado isso,

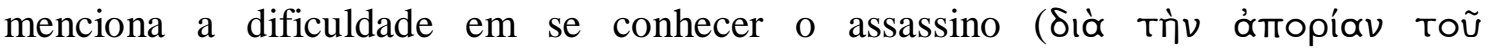
ómoктвívavtos - 2.4.2) e que os acusadores tramam contra ele (2.4.3). A partir dessa constatação, prossegue, mediante a argumentação "apagógica", revertendo os argumentos do eíkós do discurso anterior da acusação sobre os outros possíveis assassinos (2.4.4-6) e sua motivação para não ter praticado o homicídio (2.4.9): alguém que se deparou com as vítimas moribundas antes fugiu e não as interrogou, porque buscar informações sobre os assassinos seria arriscado; outros crimes podem não ter sido anunciados juntos com este, porque a ninguém interessava investigá-los; o testemunho do escravo não é confiável, porque ele não foi submetido à tortura pelos seus senhores, que são inimigos do réu; porque se desconhece o anúncio de outros crimes, é possível que o assassinato tenha sido cometido por esses possíveis malfeitores; o temor de perder a riqueza não é um motivo para assassinar, porque a situação desfavorável pode mudar. Quanto ao fato de ter ou não ter estado presente no momento do homicídio, o réu adiciona um argumento novo e inesperado:

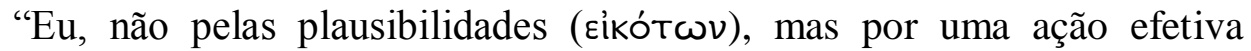

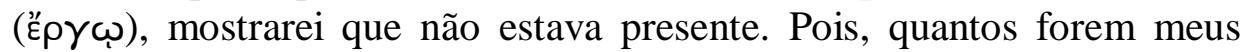
escravos e escravas, todos ofereço para serem postos à prova sob tortura

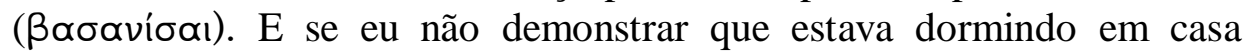
naquela noite ou que não havia saído para algum lugar, estou de acordo, então, que sou o criminoso. Mas não se trata de uma noite desconhecida: o homem morreu nas Dipólias." (2.4.8)

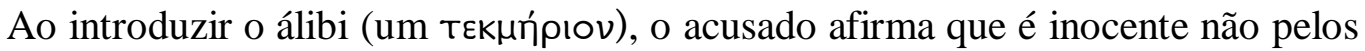

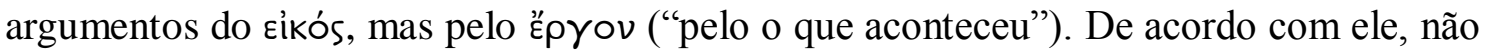
estava presente no momento do homicídio, mas estava em sua casa naquela noite e todos os seus escravos, que estão vivos e são disponibilizados para serem postos à prova sob tortura, podem testemunhar. Além do mais, com a inclusão de um detalhe importante para a confirmação de um álibi, especifica que não teria sido uma noite 
qualquer, pois ocorria em Atenas um festival anual em honra a Zeus Polieus, protetor da cidade: as Dipólias (dia 14 do mês Skirophorion - aproximadamente Junho).

Se confirmado o álibi, isso forneceria uma evidência a favor do réu, forte o bastante para decidir o caso. $\mathrm{O}$ curioso é que o réu o menciona apenas no final de seu último discurso, quando seria de se esperar que o introduzisse logo no início pelo peso dessa evidência. A menção tardia, sugerem Decleva-Caizzi ${ }^{424}$ e Gagarin $^{425}$, poderia ser um estratagema para prevenir justamente que os acusadores apresentassem uma réplica. Algo como contra-argumentar que o réu não estaria presente no momento do crime, mas que poderia ainda assim ter premeditado a morte. Por outro lado, não se pode descartar que a demora em fornecer a evidência do álibi talvez se deva à resistência do réu em considerar o testemunho de qualquer escravo confiável, como foi dito por ele mesmo anteriormente. Logo, se emprega esse recurso é para se equiparar, ao menos nesse ponto, à acusação. Vale lembrar, contudo, que esse procedimento não seria possível em um tribunal de homicídio em que os argumentos seriam conhecidos já nas audiências preliminares e seria pouco comum a introdução do ßóo ơvos no decorrer de um julgamento $^{426}$. O fato é que Antifonte não desenvolve o assunto, visto que logo na sequência faz com que a defesa rebata um argumento distinto (2.4.9), e não retorna ao álibi de maneira explícita.

Por fim, antes do encerramento de seu discurso, a defesa faz uma declaração importante: "a maioria das suposições plausíveis (Eỉkóta) é mais favorável a mim” (2.4.10): o testemunho do escravo é pouco confiável e não pode ser colocado à prova; e

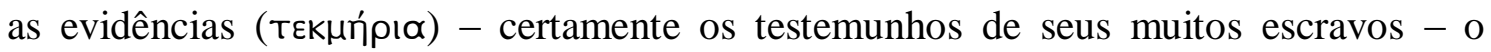
beneficiam (2.4.10). Assim, considera ter provado que a responsabilidade pelo homicídio conduz àqueles que são absolvidos pelos acusadores (2.4.10).

Se Antifonte, encerrado os dois primeiros discursos, operou por meio da contraposição eíkós/દikótepov, ao final da Tetralogia I posiciona em lados opostos o

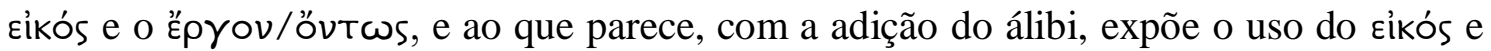
suas dificuldades quando contraposto às evidências. O álibi, como construído por Antifonte, poderia ser, de fato, refutado, mas essa declaração final sugere que, no fim,

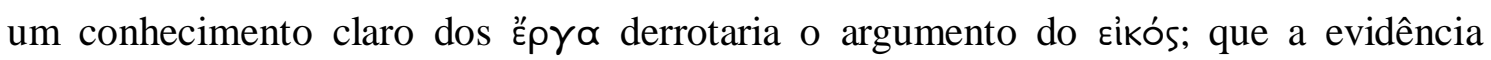
direta, quando existe, é melhor. Parece bastante claro que Antifonte constrói toda a

\footnotetext{
${ }^{424}$ ANTIPHONTIS, 1969, pp. 206-07

${ }^{425}$ ANTIPHON, 1997, p. 142

${ }^{426}$ Ibid., p. 142
} 
Tetralogia I mantendo separadas a evidência direta (ausente) e as evidências indiretas e que em nenhum momento faz com que os litigantes reconheçam, explícita ou implicitamente, que a segunda é mais eficaz que a primeira $(2.1 .2,2.2 .10,2.3 .8,2.4 .10)$, mas dá a entender que se houvesse uma verdade factual conhecida por todos, ela decidiria a questão. Na sua ausência, a evidência indireta (o cíkós) é introduzida naturalmente. Desse modo, para Gagarin ${ }^{427}$, ao mesmo tempo em que Antifonte parece privilegiar o uso do Eíkós como exercício argumentativo, ele demonstra também, segundo ele, o seu papel limitado.

É interessante observar que essa perspectiva pode ser encontrada em Górgias, do mesmo período. Em Elogio de Helena, trata-se de um discurso em que o autor aceita a versão tradicional dos fatos, mas, por Eikós, sugere um conhecimento diferente da partida de Helena para Troia ou de sua responsabilidade na ação. Em Defesa de Palamedes, em que, a exemplo da Tetralogia I, os fatos estão em disputa, são empregados vários argumentos baseados no eíkós, ainda que apenas um seja explícito (9). Em linhas gerais, Palamedes é falsamente acusado e condenado por uma traição contra os gregos que não cometeu. Todo o discurso é uma tentativa de refutar uma falsa acusação apresentada por Odisseu. O uso do argumento do Eikós, no entanto, é feito em prol da verdade (24; 33-35). A exemplo de Antifonte na Tetralogia I, em Defesa de Palamedes, Górgias em nenhum momento parece sugerir que os Eikóta são mais respeitados ou mais dignos de credibilidade do que a verdade, como alegado pelo Sócrates platônico no Fedro, ou que são um melhor guia para a verdade do que a evidência direta. O que esses dois textos parecem insinuar é que tais argumentos, embora nem sempre efetivos, são algumas vezes o único meio disponível para suportar um caso verdadeiro ${ }^{428}$, não sendo, portanto, uma questão apenas de escolha, mas, sobretudo, de necessidade.

\subsubsection{O miasma}

Somado aos argumentos do Eikós, outro aspecto importante em Antifonte na Tetralogia I, e que parece constituir um argumento à parte, é o efeito contaminador de um crime de sangue por meio da exploração de uma espécie de crença religiosa do

\footnotetext{
${ }^{427}$ ANTIPHON, 1997, p. 124

${ }^{428}$ GAGARIN, 1994, p. 55
} 
miasma. O assunto é tratado nos proêmios e epílogos dessa Tetralogia e não interfere diretamente nos argumentos centrais dos litigantes. Sua configuração se dá da seguinte maneira:

No proêmio de seu primeiro discurso (2.1.3) a acusação lembra que o assassino

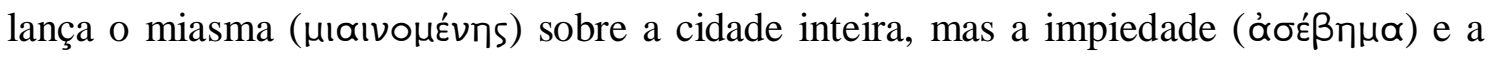

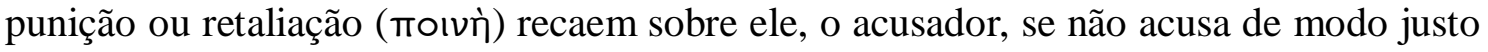
- seja por deixar em liberdade o culpado, seja por condenar um inocente, seja por contribuir para o erro dos juízes. Acreditando ter provado o verdadeiro responsável pela morte, a partir de seus argumentos, a acusação conclui no epílogo de seu discurso

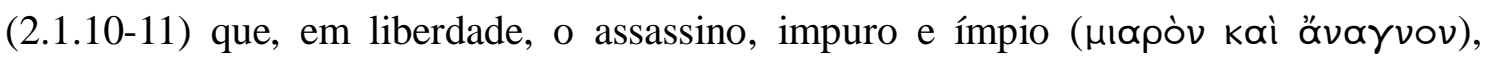
profana os lugares sagrados, contamina os inocentes, torna a terra estéril e prejudica os negócios da cidade. Por isso, convém aos juízes punir o criminoso, devolvendo a ele a

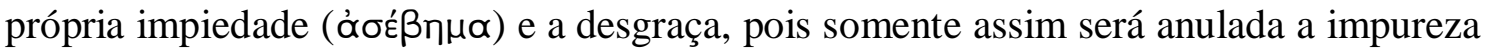
que emana do assassino e que contamina toda a cidade.

No epílogo de seu primeiro discurso (2.2.11), a defesa, depois de argumentar que os acusadores, incapazes de encontrar o verdadeiro assassino, acusam um inocente de modo injusto (2.2.2), responde que os que acusam um inocente e deixam em liberdade o culpado são responsáveis pela esterilidade da colheita; e os juízes, por serem

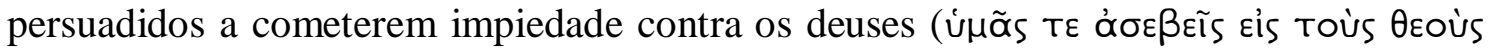

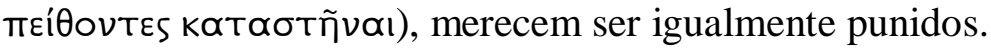

A acusação, no epílogo de seu segundo discurso (2.3.9-11), acreditando ter provado que o réu é culpado mediante os argumentos por ela apresentados, alerta os juízes (2.3.9) para o fato de que o acusado tenta transferir para eles próprios a sua impureza ( $\mu$ ıрíav) e enfatiza que, caso o réu seja absolvido, depois de tudo o que foi dito em seu discurso de acusação, o espírito do homem morto que busca vingança

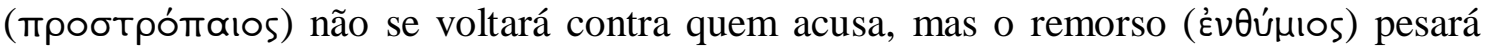
sobre os juízes, pois foram incapazes de punir o assassino (2.3.10). Insistindo na responsabilidade dos juízes, a acusação os intima a auxiliar o morto, punir o assassino e purificar a cidade, para que também eles possam ficar livres da impureza ( $\mu \iota$ pías) que emana do acusado (2.3.11).

A defesa, por sua vez, no epílogo de seu segundo discurso (2.4.11-12), pede aos juízes que não deixem o culpado em liberdade e condenem um homem inocente e puro. Falando em nome do morto, lembra da necessidade de se punir ou retaliar (moıvì) o 
responsável pelo crime (2.4.11). Após insistir na sua inocência, pede aos juízes que

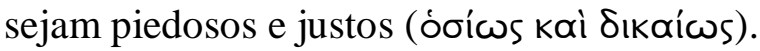

\subsubsection{O $\mathrm{O} \theta 0$ os}

Um último aspecto importante na Tetralogia $I$ é a construção por parte de Antifonte de um ह̌ $\theta$ os do orador frequentemente utilizado em defesas no tribunal ${ }^{429}$. Não se configura, contudo, em uma tíotıs (ou meio de persuasão) ${ }^{430}$, mas em um elemento subsidiário e de menor importância no discurso. Trata-se da citação de serviços prévios à cidade e de traços positivos na conduta do orador, com o intuito de persuadir os juízes de sua inocência mediante exposição de seu caráter moral (suas virtudes cívicas). Ele é inserido por Antifonte no final do primeiro discurso da defesa, em 2.2.12. Nele, o réu fornece aos presentes uma lista dos mais diversos serviços realizados, tais como "fazer contribuições financeiras", "exercer a função de trierarca inúmeras vezes", "desempenhar a função de corego com maestria", "ajudar muitos com empréstimos" e "garantir grandes cauções em favor de muitos". Como lembram Gagarin ${ }^{431}$ e Maidment ${ }^{432}$, os três primeiros serviços - realizar os Eiơфopaí, ser um tpıńpapxos e

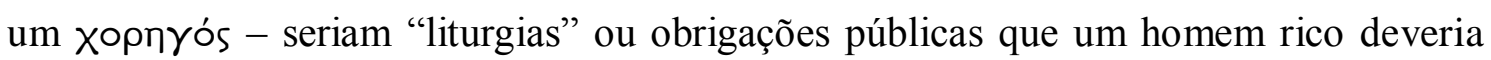

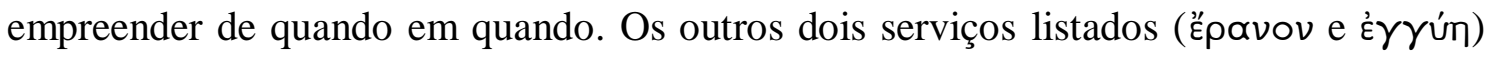
seriam maneiras privadas bastante comuns de ajudar amigos. Gagarin ${ }^{433}$ acredita que, em um caso real, o defensor certamente mencionaria apenas serviços específicos, não listando algo tão amplo como faz o réu nesse discurso. O réu ainda declara que seus

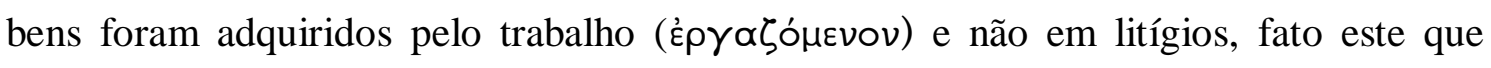
poderia lhe render a alcunha de sicofanta. Ademais, acrescenta outras duas informações

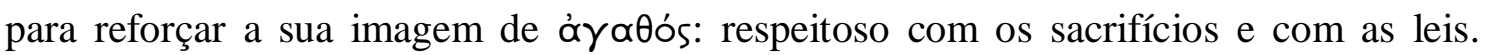
Com efeito, esse argumento será rebatido pela acusação em 2.3.8 com o raciocínio segundo o qual fazer empréstimos em dinheiro e desempenhar a função de corego são indícios de riqueza, não de isenção de responsabilidade no crime.

\footnotetext{
${ }^{429}$ Cf. Andócides 4.41-42; Lísias 13.77; 21.1-5; 24.25; Iseo 7.38-42; Demóstenes 54.44.

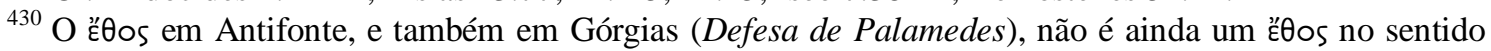
forte de Aristóteles.

${ }^{431}$ ANTIPHON, 1997, p. 134

${ }^{432}$ ANTIPHON,1953, pp. 66-7

${ }^{433}$ ANTIPHON, 1997, p. 134.
} 


\subsection{Comentário da Tetralogia II}

O caso hipotético em questão diz respeito à morte de um garoto durante exercício de lançamento de lanças. Em linhas gerais, um jovem estava praticando lançamento aparentemente na presença de treinadores quando um garoto, que corria na área reservada aos exercícios para apanhar os objetos para os lançadores, foi atingido e morto. Em um tribunal hipotético, enquanto a acusação será feita pelo pai da vítima, a defesa será feita pelo pai do acusado.

Se na Tetralogia I Antifonte compõe um caso em que os fatos estão em disputa, na Tetralogia II os fatos são aceitos pelos litigantes: trata-se de um homicídio nãointencional. Entretanto, isso não significa que a disputa será facilmente resolvida, pois, por um lado, a defesa não aceita a responsabilidade de seu filho pela morte do garoto e, por outro, a acusação defende a corresponsabilidade do jovem na morte de seu filho. A complexa questão da causa e da responsabilidade será, então, o foco principal dos discursos dos litigantes. Na medida em que a circunstância da morte envolve um erro

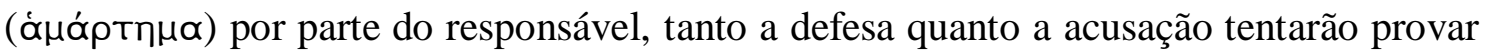
em seus discursos que ele pertence ao outro lado. E uma vez que a interpretação do evento está em disputa - a defesa concorda com a acusação que qualifica a ação como

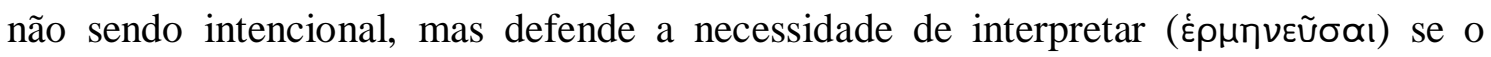
acusado é culpado ou inocente - será fundamental a busca pelo seu "sentido preciso"

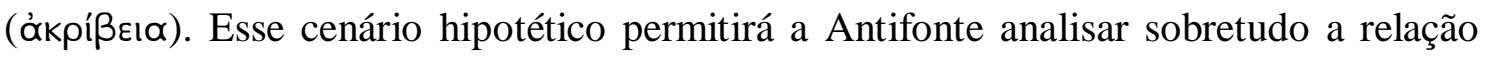

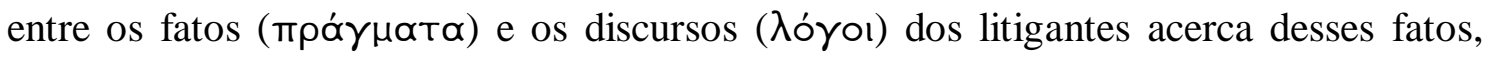
um dos aspectos importantes dessa Tetralogia II.

\subsubsection{Da disposição dos discursos}

Nela, como nos demais discursos, referências a uma crença religiosa do miasma estão ausentes dos argumentos centrais para se concentrarem no proêmio e no epílogo. Omitida na Tetralogia I, uma narrativa é apresentada pela acusação em seu primeiro discurso. Nela, são aduzidos, resumidamente, os fatos essenciais: “(...) estando no ginásio, meu filho, ao ser atingido no meio de suas costas pela lança atirada por esse jovem, morreu de imediato" (3.1.1). Entretanto, nenhum argumento é desenvolvido nesse breve discurso. Eles serão oferecidos primeiro pela defesa, para somente então 
serem debatidos pelos litigantes nos dois discursos finais. Como observou Gagarin ${ }^{434}$, a brevidade do primeiro discurso da acusação reforça a impressão de que, na opinião da mesma, um veredito favorável seria tão óbvio que uma resposta da defesa não seria esperada, como é dito pela própria acusação no início do seu segundo discurso: "Eu, dando prova de grande estupidez, não imaginei que ele replicaria; caso contrário não teria me privado da metade da minha acusação pronunciando um só discurso ao invés de dois." (3.3.2). Uma tese defendida por Gagarin é a de que Antifonte parece estar indicando no discurso da acusação uma visão mais tradicional para esse tipo de caso, enquanto que um raciocínio mais sofisticado é empregado pelo autor para construir a argumentação da defesa ${ }^{435}$.

A Tetralogia II, quanto a sua estrutura, poderia, de modo ilustrativo, ser apresentada da seguinte maneira:

\section{Primeiro discurso da acusação (3.1)}

Proêmio, narrativa e epílogo (3.1-2): breve declaração dos fatos e apelo por justiça.

\section{Primeiro discurso da defesa (3.2)}

Proêmio (1-2): exposição de sua situação pessoal. A defesa faz uso da captatio benevolentiae e de alguns topoi tais como o de ser ele um homem tranquilo e não atuante em debates, mas forçado a fazer um discurso em um tribunal e a falar de modo que não lhe é natural.

Argumentação (3-9): a defesa sustenta um argumento principal: seu filho atirou a lança que matou o garoto, mas este é responsável pela própria morte, pois cometeu um erro. Um novo argumento é acrescentado: visto que a responsabilidade é do garoto, o jovem sequer cometeu homicídio não-intencional.

Epílogo (10-12): a defesa reforça a inocência do filho e suplica aos juízes pela absolvição do mesmo.

\section{Segundo discurso da acusação (3.3)}

Proêmio (1-4): a acusação critica a postura da defesa, lamenta não ter desenvolvido mais seu primeiro discurso e apela aos juízes pela condenação do jovem.

Argumentação (5-10): a acusação sustenta um argumento principal: o jovem também tem responsabilidade na morte, pois atirou a lança que matou o garoto, ainda

\footnotetext{
${ }^{434}$ ANTIPHON, 1997, p.146.

${ }^{435}$ GAGARIN, 1998, p. 30
} 
que este tenha cometido um erro; sendo o homicídio obra de ambos, o jovem também deve ser punido por sua participação na ação.

Epílogo (11-12): a acusação reforça a necessidade de punição e expulsão do jovem da cidade e alerta para os riscos dos próprios juízes contraírem o miasma do assassino.

\section{Segundo discurso da defesa (3.4)}

Proêmio (1-2): declaração sincera das intenções de cada litigante: cada um considera seu discurso como sendo o mais justo. A defesa intima os juízes a julgar os fatos de modo equânime, examinando-os a partir dos discursos dos litigantes.

Argumentação (3-8): a defesa reforça os argumentos de seu primeiro discurso: o garoto errou e por seu próprio erro foi punido.

Epílogo (9-10): Menção ao espírito vingador do morto: a defesa aconselha os juízes a absolver seu filho, para que o espírito do morto não busque vingança contra eles.

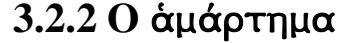

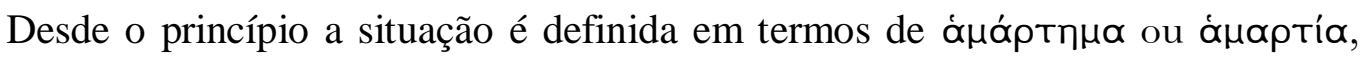
Após o breve discurso inicial da acusação, em que nenhum argumento é desenvolvido, a defesa elabora seu discurso com um argumento principal: o garoto cometeu um erro

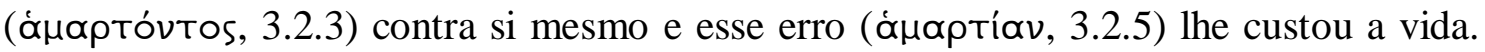
Para a defesa, seu filho apenas seria responsável se tivesse atingido o garoto fora da área estipulada para o lançamento, o que, segundo ela, não aconteceu: o garoto foi atingido ao correr sobre a trajetória da lança em um momento inadequado. A fim de provar que o morto é o único responsável pela desgraça, a defesa compara as ações das duas partes com as daqueles presentes no ginásio durante o exercício de lançamento, empregando, para isso, várias antíteses hipotéticas contrapostas ao que supostamente seria o fato:

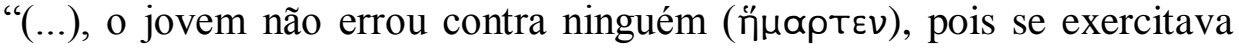
fazendo não o que era proibido, mas o ordenado; lançava não entre os que faziam ginástica, mas no lugar demarcado para os lançadores; atingiu o garoto não ao errar ( $\dot{\alpha} \mu \alpha \rho \tau \omega ́ v)$ a área de lançamento, atirando a lança contra os que estavam afastados, mas fez exatamente tudo o que havia concebido, tudo intencionalmente". (3.2.7)

Gagarin entende que, nesse argumento, Antifonte forneceria uma complexa declaração acerca do comportamento de cada pessoa por comparação com o de outras 
na mesma situação ${ }^{436}$. Com essa declaração a defesa pretende provar que seu filho estaria seguindo um padrão razoável de comportamento, que seria o padrão seguido por um homem normal. Mais, ela ressalta também que seu filho não teria agido sob a

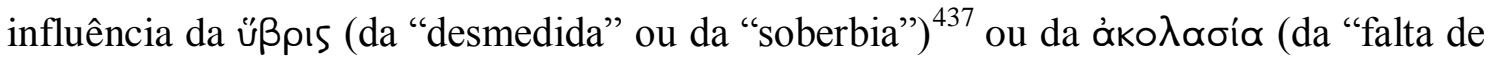
auto-controle" ou "desordenadamente") (3.2.3), comportamentos, estes, que provavelmente fariam de seu filho o responsável pela morte. Em tal situação, como é notado por Gagarin $^{438}$, agir com ǔßpıs favoreceria a acusação de assassinato intencional,

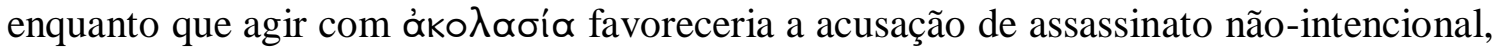
que decorre de um erro ou de uma falha.

Para a defesa, portanto, seu filho lançou seguindo as ordens dos instrutores que, tudo indica, estariam presentes; e lançou no lugar de lançamento adequado, no momento adequado e na direção adequada. Do ponto de vista da defesa, não há nenhum erro na conduta do jovem; em contrapartida, todo o erro "pertence à vítima" (3.2.8). A defesa, então, chega ao ponto de argumentar que a justiça já foi feita, pois aquele que errou foi punido simultaneamente ao erro cometido (3.2.8). Curiosamente, não parece interessar ao defensor que o homicídio se configure sequer em homicídio não-intencional, como quer a acusação ("Pois por causa do erro do próprio morto, o jovem é absolvido da acusação de tê-lo matado sequer de modo não-intencional; (...)”, 3.2.9). Em primeiro

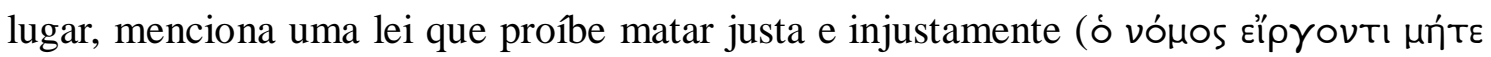

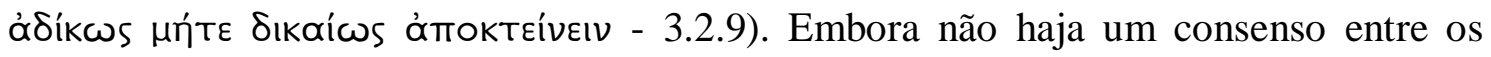
comentadores de Antifonte acerca dessa lei ${ }^{439}$, o fato é que ela é usada, sobretudo pela

\footnotetext{
${ }^{436}$ ANTIPHON, 1997, p. 146.

${ }^{437}$ Aqui, o termo úßpıs comportaria o sentido de uma agressividade relacionada com a maldade, manifestada sob a forma de uma violência física ou de um comportamento insultuoso.

${ }^{438}$ ANTIPHON, 1997, p. 149

${ }^{439}$ Alguns comentadores da obra de Antifonte reconhecem a complexidade da declaração de uma lei que

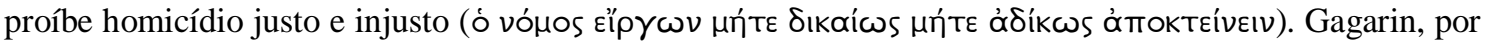
exemplo, na introdução de sua edição dos discursos de Antifonte, explica que uma lei que proíbe homicídio justo é, por si só, um paradoxo e não poderia ter sido uma lei efetiva em Atenas ou em qualquer outro lugar; antes teria sido "um produto do espírito sofístico da experimentação provocativa" que constitui as Tetralogias. (GAGARIN, 1997, p. 24). Em outra obra, Gagarin sugere que o "justa e injustamente" pode ser entendido como equivalendo a "intencional e não-intencional", e que, nesse sentido, tal lei não seria estranha à lei ateniense de homicídio. (GAGARIN, 1998, p. 33). Essa equivalência, contudo, valeria apenas para a Tetralogia II, não para a III. Sealey, por sua vez, observa que essa lei apresentada nas duas Tetralogias não parece ser um mero comentário de uma lei mais complexa, visto que a acusação e a defesa a conhecem. Antifonte, contudo, introduyyhyz essa proibição nas duas Tetralogias como uma declaração da lei. A exemplo de Gagarin, Sealey entende que se "justo" e "injusto" significam, respectivamente, "permitido por lei" e "proibido por lei", então uma das duas proibições combinadas é auto-contraditória. Por isso, Sealey pensa que parece fazer mais sentido a conclusão de Gagarin de que antes de declarar ou resumir uma lei ateniense, Antifonte está elaborando um comentário
} 
defesa, com o objetivo de convencer os juízes da completa inocência do jovem. Em segundo lugar, a defesa, curiosamente, trata a consequência de uma possível responsabilidade do jovem como mais grave do que realmente pareceria. Conforme suas palavras, ela própria será levada a desgraças extremas, pois seu filho sofrerá ações ímpias ao carregar o erro que não lhe pertence (3.2.10), e sua vida será insuportável por

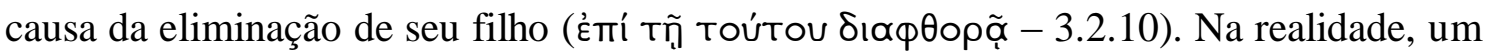
homicídio não-intencional, do ponto de vista do direito ateniense, implicaria em exílio e

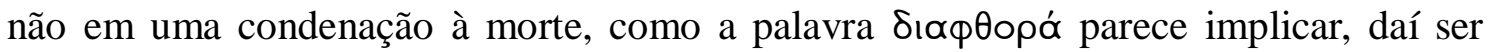
entendido como uma ênfase dramática por alguns comentadores ${ }^{440}$.

O acusador, por sua vez, considerando ter desperdiçado seu primeiro discurso, vê-se agora obrigado a apresentar em um só toda a sua acusação, deixando sem resposta o primeiro discurso da defesa. No entanto, seu segundo discurso também será a réplica ao primeiro da defesa. Seu argumento inicial implica em sustentar, primeiro, que o jovem atirou a lança e, por isso, é o assassino, ainda que não pretendesse matar (3.3.5); segundo, que seu filho não é o responsável pelo erro: por um lado, seu filho não errou

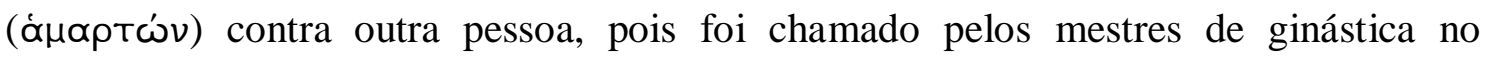

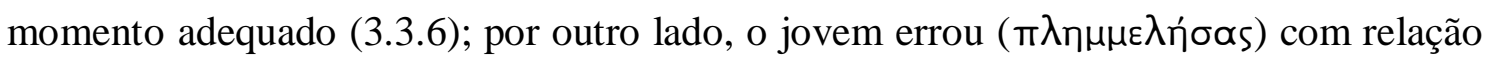

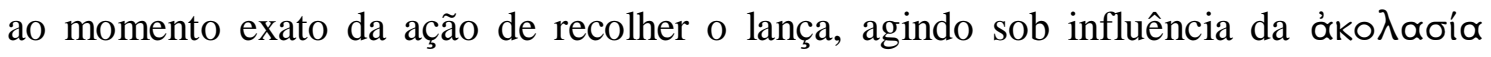
(3.3.6). Acrescenta também que a tal lei que proíbe matar justa e injustamente, mencionada pela defesa, declara que todos os assassinos devem ser castigados, mesmo se não pretenderam matar ("é justo que o que matou sem intenção sucumba pelos males

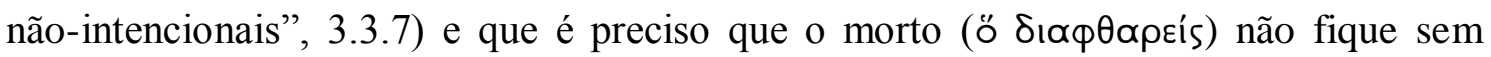
vingança, pois foi lesado, ainda que sem intenção (3.3.7). E mesmo se o infortúnio (átuXía) ou os deuses desempenharam algum papel no erro, ainda assim o assassino merece ser punido por esse erro (3.3.8). Em vista de tudo o que foi dito, a acusação

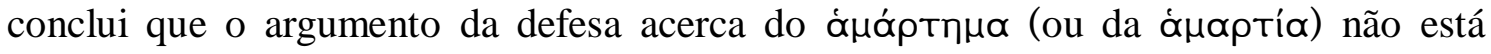
correto, pois enquanto o jovem atirou a lança, seu filho não errou contra ninguém (3.3.9). Se o interesse da defesa, em seu primeiro discurso, foi mostrar aos juízes que o jovem não havia cometido sequer homicídio não-intencional, a acusação, no final de seu

moral sofisticado e provavelmente incomum ao século V a.C.: alguns tipos de homicídio, embora ainda penalizados na lei, são convalidados como justos por uma perspectiva moral mais desenvolvida. (SEALEY, 1984, pp. 75-6). Curiosamente, essa lei é mencionada na Tetralogia II por ambos os litigantes (3.2.9 e 3.3.7), mas inicialmente pela defesa, e na Tetralogia III, apenas pela defesa (4.2.3 e 4.4.8), quando o mais natural é que fosse inserida pela acusação e evitada pela defesa.

${ }^{440}$ ANTIPHON, 1997, p. 152; ANTIPHONTIS, 1969, p. 221 
discurso, está preocupada agora em mostrar que tanto o erro quanto o homicídio são obra do acusado e da vítima (3.3.10), ainda que tenha insistido em boa parte de seu discurso que seu filho não cometeu nenhum erro. Utilizando antíteses hipotéticas, a acusação afirma que, se é justo, como argumenta seu oponente, "que o próprio garoto seja o assassino de si mesmo por ter avançado na trajetória da lança ao invés de ter ficado parado sem se mover, tampouco o jovem está livre de culpa, a menos que ele não tenha atirado a lança, mas tenha ficado imóvel" (3.3.10), quando seu filho morreu. Ao final, o principal argumento da acusação consiste em sustentar que o jovem não pode ficar totalmente livre da culpa ( $\alpha i$ Tía), pois desempenhou algum papel na morte do garoto; porque participou da ação, o jovem se transforma em corresponsável pela morte e, portanto, deve ser punido (3.3.11).

Em resposta, a defesa retoma o argumento segundo o qual o garoto foi morto não pelo jovem, mas por si mesmo, visto que morreu ao avançar sobre a área de lançamento e não estando imóvel (3.4.4). Nesse ponto, ela insinua a possibilidade de o mestre de ginástica, ou o instrutor, ser o responsável pela morte, caso o garoto tenha avançado ao ser chamado por ele (3.4.4). Mas Antifonte não desenvolve a tese e o mestre de ginástica não terá relevância nas argumentações dos litigantes. A defesa, então, retorna às antíteses hipotéticas do seu primeiro discurso: o jovem agiu exatamente como os outros lançadores agiram e "não errou a área de lançamento mais do que seus companheiros de exercícios" (3.4.5); o garoto, por sua vez, agiu diferentemente do outros espectadores, que estavam parados; se ele tivesse ficado com os outros espectadores, não teria sido atingido. De acordo com o raciocínio da defesa, se seu filho é corresponsável pelo homicídio, todos aqueles que lançavam também o são. Eles apenas não atingiram alguém, pois ninguém avançou sob o alcance de seus lanças (3.4.6). Além do mais, menciona que o erro do garoto era evitável, pois poderia ter visto os lançadores e ficado imóvel, precavendo-se de alguma desgraça. Quanto ao jovem, ele não poderia ter visto o garoto correndo de um lado para o outro nem ter se precavido

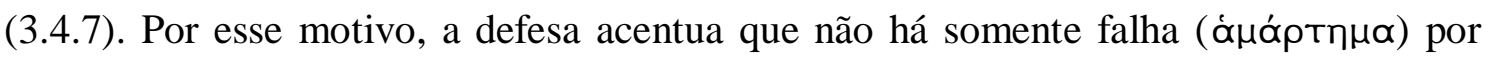

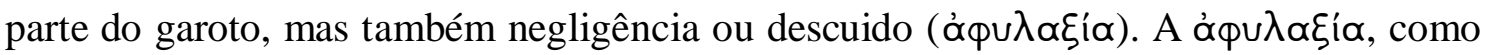

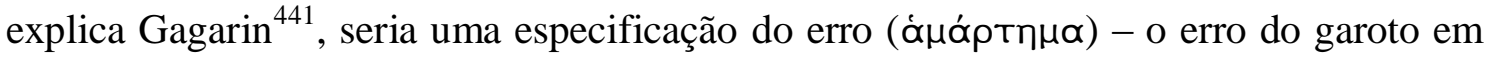
ser negligente ao recolher a lança em um momento inadequado - e diferiria da

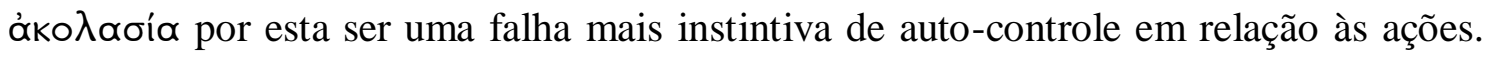

${ }^{441}$ ANTIPHON, 1997, p. 159 
Como no primeiro discurso, a defesa se preocupa com a possibilidade de responsabilidade conjunta e, por isso, continua a insistir que seu filho não cometeu nenhum erro e que, portanto, não deve dividir a culpa com o morto. E como havia dito em seu primeiro discurso, que pareceu absurdo para a acusação, "o garoto, tendo sido morto por seus próprios erros, ao mesmo tempo errou e por si próprio foi punido" (3.4.8); uma vez que o assassino foi punido, "o homicídio não fíca sem vingança" (3.4.8). Ao final, a lei que proíbe matar justa e injustamente é novamente mencionada: deve ser exaltada "pois de maneira correta e justa pune com sofrimentos nãointencionais os que matam sem intenção" (3.4.8).

A fim de compreender o sentido de $\alpha \dot{\mu} \alpha \dot{\rho} т \eta \mu \alpha$ na Tetralogia II, comentadores, como Decleva-Caizzi 442, consideram pertinentes atentar para a definição que Aristóteles fornece dela na Retórica (I, 1374 b5). Em uma passagem em que o filósofo reflete sobre a justiça e a equidade, ele diz que as ótuxń $\alpha_{\alpha} \alpha$ ("desgraças” ou “infortúnios") ocorrem quando não há cálculo nem maldade; as á $\mu \alpha \rho t \eta ́ \mu \alpha t \alpha$ ("erros"

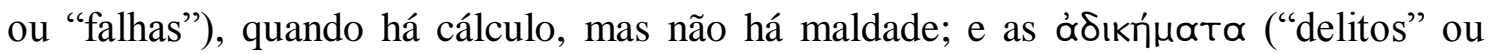

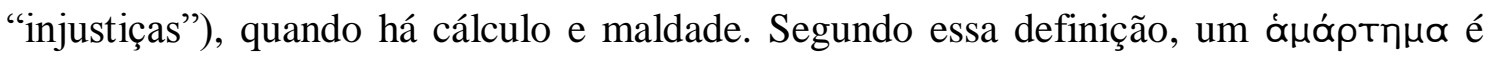
um "erro" ou uma "falha" pelo qual o agente da ação tem alguma responsabilidade, mas

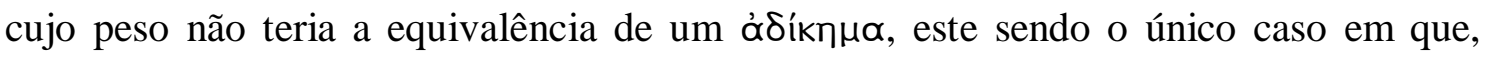
segundo Aristóteles, as ações seriam moralmente reprováveis e passíveis de punição. Os dois primeiros casos, embora apresentem uma diferença com relação à responsabilidade,

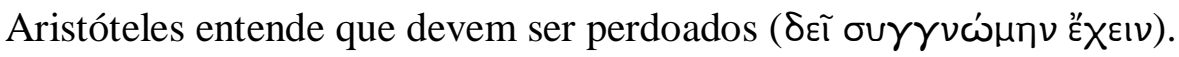

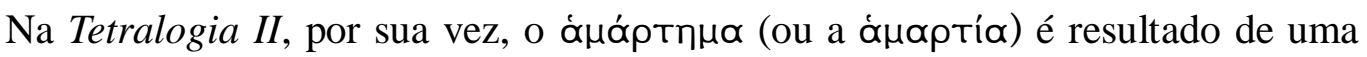
ação vista pelos litigantes como não-intencional, mas, conforme ressalta DeclevaCaizzi $^{443}$, isso não constitui um atenuante como apresentado por Aristóteles, para quem

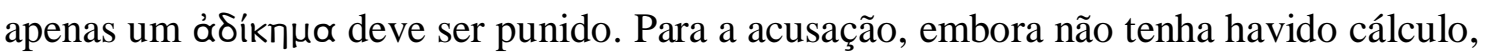
o jovem não deve ser perdoado, mas punido. O fato de não constituir um atenuante também parece ser entendido pela defesa, que busca mostrar o tempo todo que a vítima, e não o acusado, é a única responsável pelo erro. Por isso, o centro do debate é a busca, por parte dos litigantes, em provar que a responsabilidade pelo erro pertence ao outro

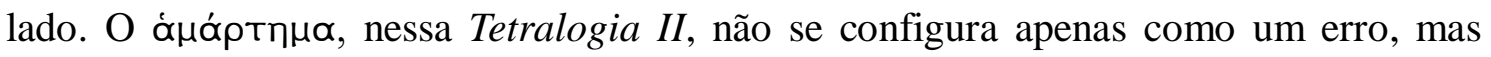

\footnotetext{
${ }^{442}$ ANTIPHONTIS, 1969, p. 56

${ }^{443}$ Ibid., p. 56.
} 
também como culpa e implica, inevitavelmente, uma expiação ${ }^{444}$, como é explicitado, por exemplo, no discurso da defesa quando ela diz que o garoto foi morto pelos próprios erros e, portanto, foi por si próprio punido; e, uma vez punido o assassino, o homicídio não fica sem vingança (3.4.8). Na medida em que não há atenuante para tal erro e há a necessidade de uma expiação, entra-se naquela esfera religiosa segundo segundo a qual

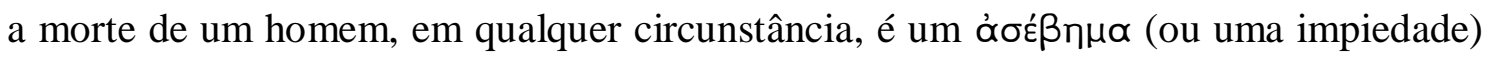
e, portanto, deve ser expiada ${ }^{445}$. É conforme esse raciocínio que talvez a lei que proíba matar justa e injustamente seja melhor explicada, ou seja, se levada em consideração a tese, melhor desenvolvida na Tetralogia III, de que qualquer homicídio é, acima de tudo, um ato de impiedade e deve ser proibido.

\subsubsection{A intenção, a causa e a responsabilidade}

Uma observação importante, referida por Decleva-Caizzi" ${ }^{446}$, é que a "intenção" não é usada modernamente por Antifonte nas Tetralogias como critério de distinção da pena. Na base do direito ático, como já foi visto, há a especificação entre um homicídio intencional e um não-intencional, e a aplicação de penas distintas para cada caso. Na Tetralogia II, contudo, ainda que Antifonte não ignore tal distinção, não utiliza seus pressupostos. Mesmo que ambas as partes concordem desde o princípio que a morte não foi intencional, isso não parece ser levado tanto em consideração. Parece haver no caso tratado uma gravidade muito maior do que um homicídio não-intencional na realidade representaria - ao menos do ponto de vista do sistema legal ateniense. A partir de uma análise geral do texto, observa-se que o autor ressalta, sobretudo, a esfera religiosa e menos a esfera jurídica, tanto que as premissas da defesa, por exemplo, são baseadas na tese de que seu filho não tinha intenção de matar, mas, sobretudo, que não matou, provavelmente interessada em evitar que seu filho incorra em um ato de impiedade e seja, do ponto de vista religioso, punido por isso. Do ponto de vista legal, a punição, no caso do jovem ser considerado o responsável por um erro não-intencional que causou uma morte, será o exílio por tempo limitado. Diante desse quadro, talvez a análise do caso, sobretudo a partir do ponto de vista religioso, explique o uso de uma palavra como

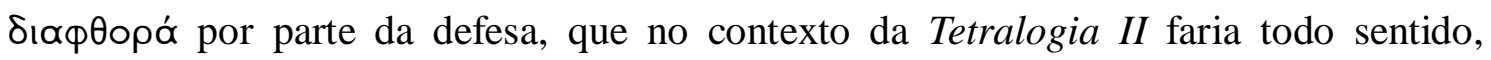

\footnotetext{
${ }^{444}$ ANTIPHONTIS, 1969, p. 56.

${ }^{445}$ Ibid., p. 57

${ }^{446}$ Ibid., p. 58
} 
deixando de ser uma ênfase dramática ou um exagero por parte do autor, mas uma preocupação mais concreta.

A exemplo dos outros discursos hipotéticos, a Tetralogia II não fornecerá uma resposta final para a questão da causa e da responsabilidade, na medida em que Antifonte não determinará o veredito ao final da disputa. Entretanto, diante do que foi visto, defesa e acusação são construídas de modo a apresentarem argumentos fortes acerca desse assunto. Gagarin, por exemplo, sugere que a discussão apresentada na Tetralogia II forneceria uma análise diferente da de Aristóteles (Ethica Nicomachea, 3.1-5) e daquela encontrada, por exemplo, em Elogio de Helena de Górgias ${ }^{447}$, do século V a.C., e na Retórica a Alexandre (1427a31-37), do século IV a.C ${ }^{448}$. É possível que essa abordagem de Antifonte refletisse as discussões contemporâneas sobre o assunto, talvez resultantes de especulações acerca de eventos acidentais ${ }^{449}$ ou, então, de casos tratados nos tribunais.

Um indício importante para essa afirmação seria, principalmente, a história mencionada por Plutarco, em Péricles 36. Nesse texto, Plutarco apresenta um caso similar ao trabalhado nessa Tetralogia. Em uma breve passagem do texto dedicada à figura de Péricles, Plutarco reporta uma discussão, que teria consumido um dia inteiro, entre o governante de Atenas e Protágoras sobre o problema da responsabilidade jurídica após um competidor ser morto em uma situação semelhante à retratada por Antifonte neste discurso.

\footnotetext{
${ }^{447}$ A tese central apresentada por Górgias nesse discurso é a de que uma pessoa (no caso, Helena) não pode ser responsabilizada se um deus é a causa principal de uma ação (a sua ida a Troia com Páris), ou, então, se outras forças (ou causas) afetam a decisão humana. Entretanto, a questão da causa e da responsabilidade parece ser mais tradicional (Cf. Odisseia, 23.222) e menos sofisticada do que a trabalhada na Tetralogia II.

${ }^{448}$ GAGARIN, 2002, p. 121

${ }^{449}$ Heródoto, por exemplo, nos proporciona uma interessante passagem no livro I da sua História (XXXIV-XLV) em que narra um homicídio decorrente de um evento acidental. Trata-se da ocasião em que Adrasto, assassino não-intencional do próprio irmão (logo, um homem "com mãos impuras" XXXV), chega a Sardes governada por Creso. Lá, é acolhido como hóspede e purificado do homicídio. Porém, durante uma caçada a um javali, Adrasto convence Creso a deixá-lo acompanhar Átis, seu filho. Creso tinha sido alertado em sonho que seu filho pereceria em uma ponta de ferro. Tendo eles achado e cercado o javali, Adrasto, atirando uma lança no animal, erra o alvo e atinge mortalmente Átis. Na volta ao palácio, Creso não culpa Adrasto pela morte de seu filho, pois ela não teria sido intencional. $\mathrm{O}$ duplamente homicida, contudo, retira a própria vida. $\mathrm{O}$ dado interessante nessa narrativa é que se trata de em um evento não-intencional resultante de um erro (embora exista o componente da vingança divina contra Creso em sua pretensão de se considerar o homem mais feliz de todos) e que há a presença do miasma (um homem contaminado pelo homicídio que propaga seu contágio), o que remete, em algum sentido, a alguns aspectos encontrados nessa Tetralogia (a não-intencionalidade da ação, o erro e o miasma).
} 
[2] (...) o jovem Xântipo, tendo se irritado com isso, insultava seu pai, expondo, acima de tudo, com o intuito de riso, os seus afazeres domésticos e os discursos que ele compunha em companhia dos sofistas. [3] Por exemplo, depois que um certo atleta de pentatlo atingiu Epitimos, o Farsálio, e o matou de maneira não-intencional (ákovoíws), desperdiçou um dia inteiro examinando, em companhia de Protágoras, qual dos dois, a lança ou o lançador, mais do que os juízes da competição, era necessário julgar como responsável pela desgraça segundo o

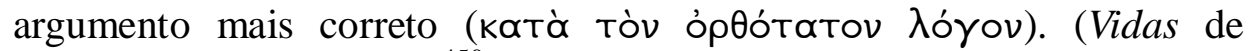
Plutarco, Péricles 36.2-3) ${ }^{450}$

Independentemente da veracidade do incidente que originou essa discussão, bem como da especulação se Antifonte teria influenciado Protágoras ou vice-versa ${ }^{451}$, ao menos as discussões de Péricles e Protágoras e a de Antifonte lidariam com a questão da causa e da responsabilidade em uma ocasião envolvendo a morte de uma pessoa em um evento acidental, mais especificamente durante uma competição atlética. Se não se pode afirmar que o tema forma a base para uma ampla discussão sobre o assunto, ao menos indicaria o interesse por isso por figuras importantes do pensamento grego, em Atenas, durante a segunda metade do século V a.C. ${ }^{452}$.

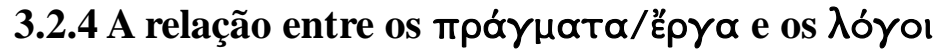

Além da argumentação central acerca da discussão envolvendo causa e responsabilidade, Antifonte também fornece, na Tetralogia II, uma importante discussão

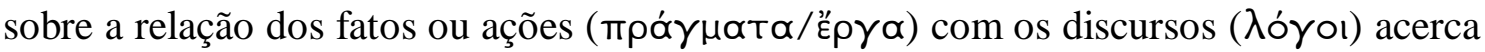
desses fatos ou ações. Trata-se de um tópico importante do pensamento e da argumentação do período, presente, por exemplo, em dois discursos de Górgias, Sobre o Não-Ser e Defesa de Palamedes, e no discurso Ájax de Antístenes. Mas é, sobretudo, nas Tetralogias de Antifonte e na História da Guerra do Peloponeso de Tucídides que ele será mais bem desenvolvido.

Em Sobre o Não-Ser, Górgias apresenta uma posição extrema através do argumento aparentemente absurdo segundo o qual a) nada existe (66-76); b) se algo

\footnotetext{
450 Tradução minha.

${ }^{451}$ Acredita-se que Protágoras tenha realmente visitado Atenas por volta de 430 a.C. Essa visita teria sido retratada no diálogo Protágoras de Platão. Entretanto, sua relação com Péricles dataria de pelo menos 440 a.C., quando foi escolhido, por este, para elaborar uma constituição para a nova colônia ateniense em Túrio. (KERFERD, 2003, pp. 76-7 ; O' SULLIVAN, 1995, pp. 18-20).

${ }^{452}$ ANTIPHON, 1997, pp. 144-45; O'SULLIVAN, 1995, p. 19.
} 
existe, não pode ser conhecido (77-82); e c) se existe e pode ser conhecido, não pode ser comunicado para outros (83-87). Um dado interessante nesse argumento é que a palavra ( $\lambda$ óyos) não representa a realidade, pois não pode comunicá-la, embora Górgias mencione que é com ela que indicamos algo (84). Já em Defesa de Palamedes, há uma passagem no final do discurso em que o herói apela aos juízes para que, na busca pela verdade do que aconteceu, entre outras coisas, não depositem mais atenção às palavras

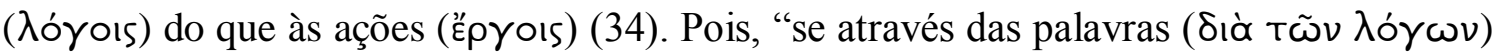

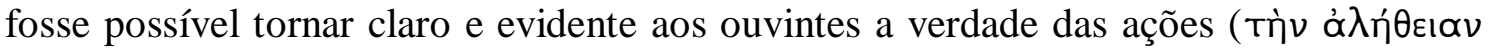

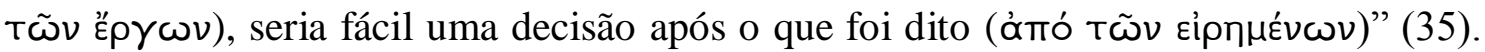
No entanto, como destaca Palamedes na sequência, "isso não é assim" $(35)^{453}$.

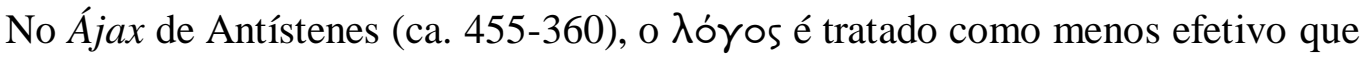
o Épyov. Isso é explicitado, primeiro, quando Ájax pergunta a quem compete julgar o caso envolvendo as armas de Aquiles: "que tipo de justiça poderia haver se os juízes

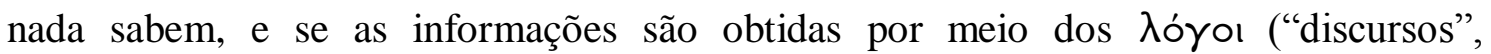
“argumentos”, “palavras”)?” (1.5). O evento (то пра́ $\gamma \mu \alpha)$, que será narrado por Ájax

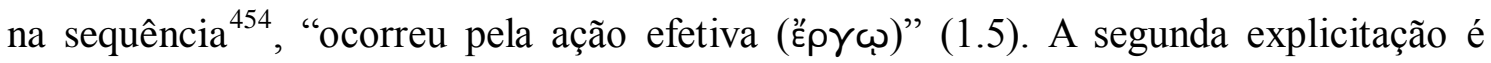

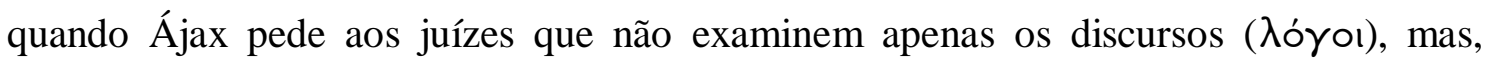

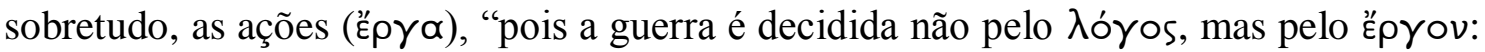
não é possível responder aos inimigos com $\lambda$ óyoı" (7.5), mas com ações, "em silêncio - lutando e triunfando ou sendo escravizado". E finaliza com uma importante passagem afirmando que:

“(...) em nada o discurso ( $\lambda$ óyos) tem mais poder em comparação com a ação (ह́pyov); (8.1) nem um homem prestará auxílio a vocês apenas

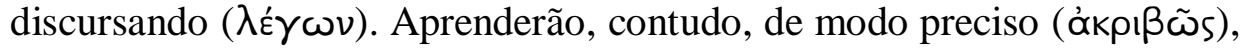
que, por causa da ausência dos fatos, muitos e longos discursos são pronunciados. Mas, ou vocês digam que não entendem as coisas ditas e

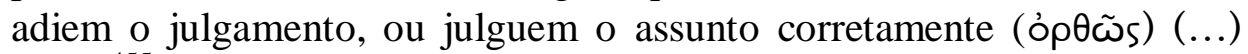
$(8.5)^{, 455}$.

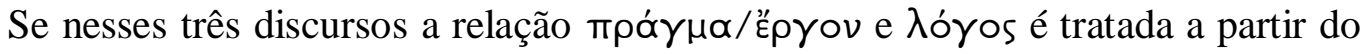
contraste entre eles ("fato" ou "ação" vs. "palavra" ou discurso", "realidade" vs. "aparência" ou "simulação"), em Antifonte, especificamente nesta Tetralogia II, e em

\footnotetext{
${ }^{453}$ Tradução minha.

${ }^{454} \mathrm{Em}$ linhas gerais, Ájax defende que seria mais digno ele receber as armas de Aquiles, pois é mais virtuoso que Odisseu. Segundo Ájax, enquanto ele as quer para devolvê-las aos amigos do herói morto, Odisseu as quer para vendê-las.

${ }^{455}$ Tradução minha.
} 
Tucídides, na História da Guerra do Peloponeso, ela se desenvolve de maneira mais sutil.

Com relação à Tetralogia II, já na abertura de seu breve discurso inicial, a

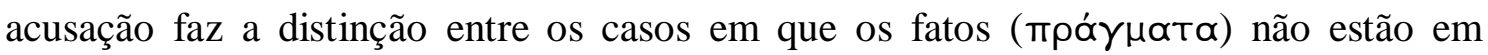
disputa, pois são evidentes, e os casos em que não há acordo acerca do que aconteceu (3.1.1). Essa distinção é importante, pois, como explica Gagarin ${ }^{456}$, se em um caso

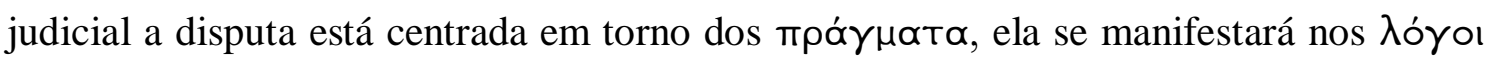
dos litigantes a serem apresentados aos juízes. Desse modo, acaba havendo uma relação

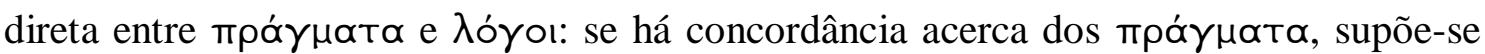

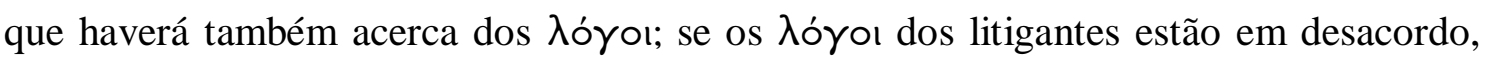
isso significa que não há concordância com relação aos прáł $\mu \alpha$ та. Para a acusação da Tetralogia II, os mpáyuata são claros: seu filho foi morto em uma circunstância específica por um jovem que não teve intenção de matá-lo. Para a defesa, ainda que não discorde, em essência, do acusador acerca do que aconteceu, seu $\lambda$ óyos ("discurso", "raciocínio", “argumento"), contudo, está em desacordo com o dela, quando o esperado seria que concordasse, visto que, segundo Gagarin, um cenário específico de

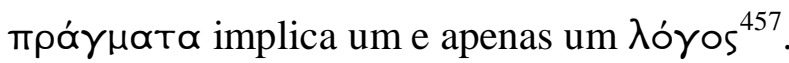

O primeiro discurso da defesa tem início com ela declarando-se forçada a

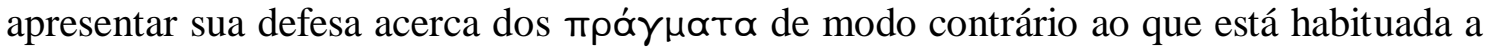

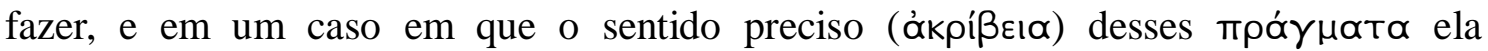
dificilmente compreende (

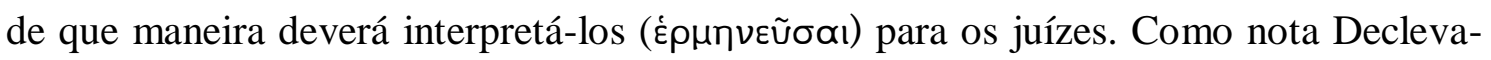

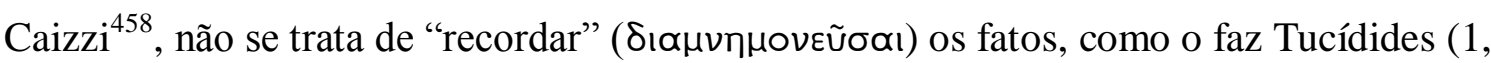

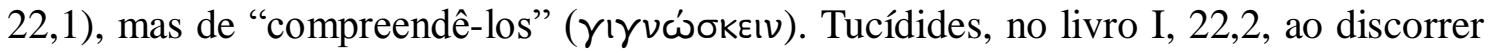
sobre a sua metodologia, menciona que "foi difícil para mim recordar a precisão das

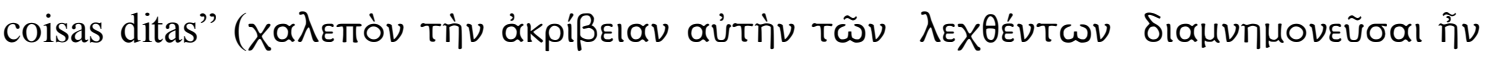
દ̇uoí), referindo-se aos discursos pronunciados por diversas personalidades antes e durante a Guerra do Peloponeso, tanto os que ele ouviu pessoalmente quanto os que lhe foram transmitidos por outras fontes. Como os litigantes da Tetralogia II, a ớkpißßı̊ (a

\footnotetext{
${ }^{456}$ GAGARIN, 2002, p. 122

${ }^{457}$ Ibid., p. 122

${ }^{458}$ ANTIPHONTIS, 1969, p. 52
} 
precisão) é justamente o que Tucídides também busca ${ }^{459}$, tanto ao recordar os termos precisos dos discursos, reproduzindo as palavras que os diferentes oradores deveriam ter usado, como ao reportar os eventos ( है$\left._{\gamma} \propto\right)$ de que ele participou ou as informações que ele obteve de terceiros "após investigar cada detalhe com a maior precisão possível"

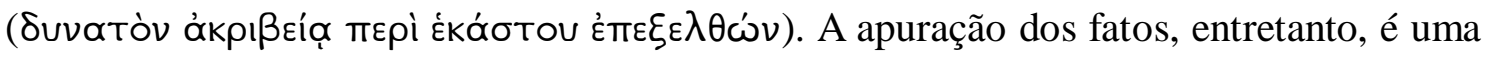
tarefa difícil, ressalta Tucídides, pois os relatos acerca das mesmas coisas apresentados pelas testemunhas oculares variam de acordo com os interesses envolvidos ou de acordo com a memória.

Na Tetralogia II, como fica claro nos discursos dos próprios litigantes, tudo indica que muitos testemunharam o evento. Mesmo assim, a defesa alerta, semelhante ao que é dito por Tucídides, que a reprodução precisa do que aconteceu não é fácil; que a sucessão dos fatos não parece simples de reconstruir pela apreensão cognitiva do que aconteceu ${ }^{460}$. Por isso a necessidade de interpretá-los: "traduzir" ou "tornar compreensível" uma realidade complexa. A questão levantada pela defesa é justamente saber qual interpretação deve-se dar ao fato para reproduzi-lo com precisão, para que se possa passar da $\delta o ́ \xi \alpha$ ("aparência" ou "opinião") para a ó $\lambda \hat{n} \theta \varepsilon ı$ ( ("verdade"). A antítese $\delta o ́ \xi \alpha / \alpha ̉ \lambda \eta ́ \theta \varepsilon ı \alpha$, que parece ter sido outro tópico característico do período ${ }^{461}$, surge nesse início da Tetralogia II, e apenas nesse início, justamente porque a defesa destaca que o que está em disputa é a verdade ou a correta interpretação dos fatos, que para o acusador são claros. A defesa, com efeito, alerta aos juízes a não darem o veredito com base na $\delta o ́ \xi \alpha$, mas com base na å $\lambda \hat{n} \theta \varepsilon ı \alpha$, pois "enquanto a aparência dos fatos (í $\delta o ́ \xi \alpha \tau \tilde{\omega} \nu$

\footnotetext{
${ }^{459} \mathrm{O}$ interesse de alguns pensadores do século $\mathrm{V}$ a.C. pelo $\lambda$ óyos resultou também no interesse pelo

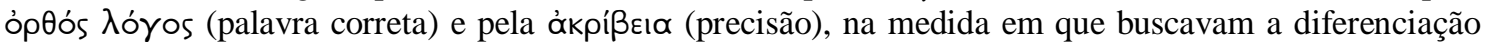
correta e precisa entre termos ou conceitos. Pródico, por exemplo, é retratado nos discursos platônicos Crátilo (384b) e Eutidemo (277e) como interessado pela correção ou exatidão dos nomes (óvouátwv

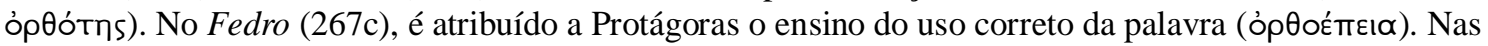
Nuvens (vv.140-42), Sócrates é apresentado por Aristófanes como aconselhando seu discípulo a

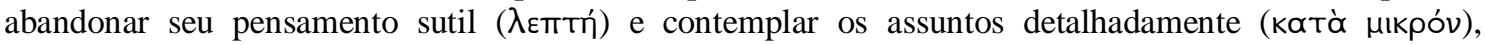

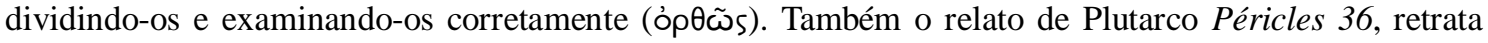
Protágoras, juntamente com Péricles, buscando determinar o argumento mais correto (ópӨótatos $\lambda$ óyos) dentre vários diferentes acerca de um evento. Na Tetralogia II, a ákpíßєıа parece corresponder ao

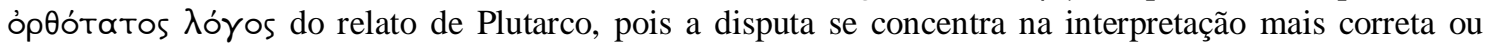
mais precisa da culpa ou responsabilidade.

${ }^{460}$ A forma como essa questão é apresentada permitirá a Antifonte exatamente centralizar suas atenções

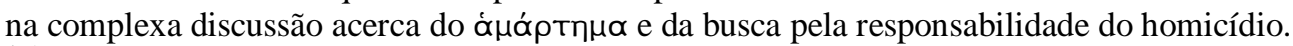

${ }^{461}$ Górgias, por exemplo, trata dessa oposição em Defesa de Palamedes (24) quando o herói questiona Odisseu se ele ousa condenar à morte um homem desconhecendo a à $\lambda \hat{n} \theta \varepsilon ı \alpha$ e baseando-se na $\delta o ́ \xi \alpha$, "a

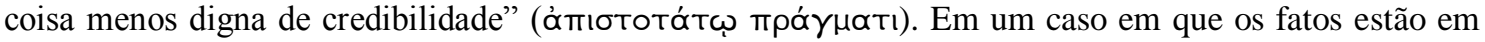
disputa, Palamedes defende que convém confiar nos que sabem, não nos que aparentemente sabem, e considerar a á̀nj́ $\theta \varepsilon ı \alpha$ mais digna de credibilidade do que a $\delta o ́ \xi \alpha$.
} 


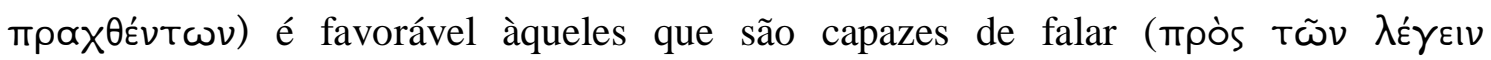

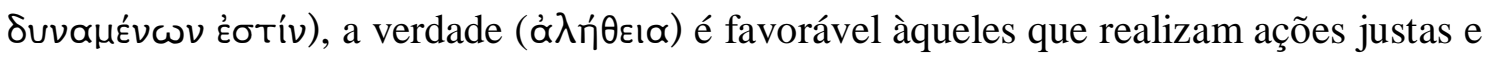

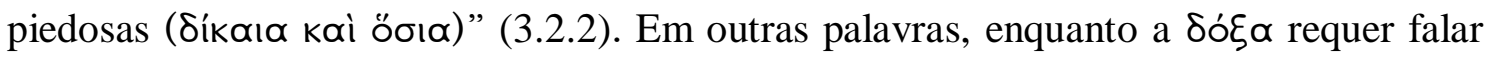

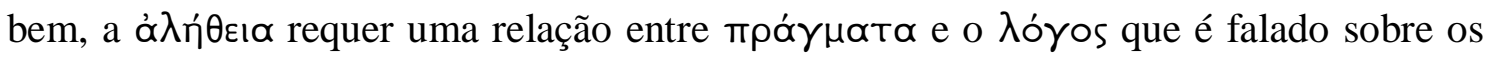
пра́) $\mu \alpha \tau \alpha^{462}$. Um dado importante é que a defesa menciona a possibilidade do uso da

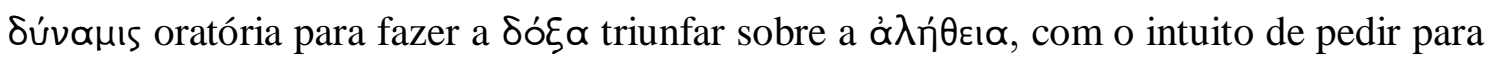
os juízes não tomarem a decisão sobre seu discurso segundo a aparência, ainda que os

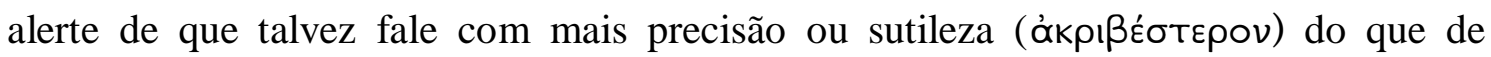
costume (3.2.2). Para Gagarin ${ }^{463}$, o retrato inicial da defesa como alguém tranquilo (ñouxíos) e alheio aos negócios públicos (ámpáy $\mu \omega \nu$ ), de alguém que não sabe como proceder e de não ser bom orador, não pode ser levado a sério ${ }^{464}$. Pois ao mesmo tempo em que tenta fornecer aos juízes a imagem de um orador inexperiente, a defesa desenvolve um argumento habilidoso, à primeira vista mais sofisticado do que o da acusação. Nesse sentido, Antifonte elabora um عُقos (caráter) do orador que será importante para a sua construção argumentativa subsequente. No proêmio do discurso da defesa, o caráter do orador é apresentado a partir de um foco favorável a ele; atribui a si mesmo um caráter moralmente positivo: o de não ser um orador habilidoso (em um sentido negativo de especializado ou experimentado, capaz de manipular a audiência) e o de ser um cidadão simples, honesto, exemplar, em dia com os seus deveres cívicos ${ }^{465}$.

Em suma, como observa Gagarin ${ }^{466}$, o ponto crucial introduzido pela defesa acerca da relação dos fatos com as palavras/discursos consiste em dizer que os

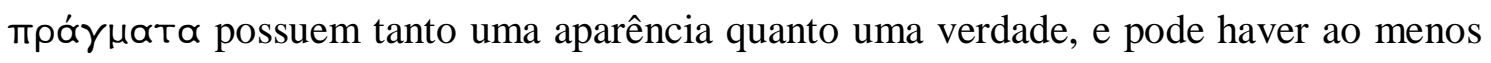

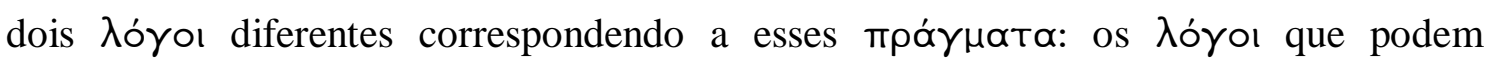
comunicar a sua aparência ou a sua verdade. No decorrer de seu discurso, a defesa argumenta que seu filho, "ao atirar lanças em companhia de outros jovens de mesma idade, de fato lançou, mas não matou ninguém, conforme a verdade do que ele fez

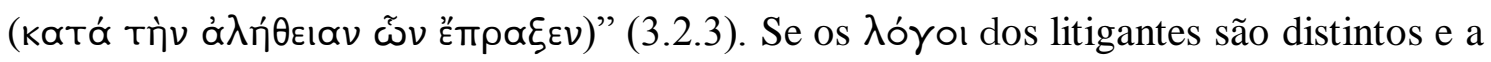
defesa considera que o seu comunica a verdade do que aconteceu ("de fato lançou, mas

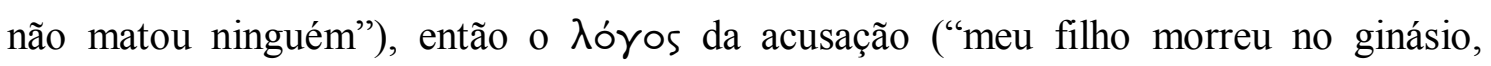

\footnotetext{
${ }^{462}$ GAGARIN, 2002, pp. 122-23.

${ }^{463}$ Ibid., p. 123

${ }^{464}$ Cf. nota 233

${ }^{465}$ Cf. 2.4 .12

${ }^{466}$ GAGARIN, 2002, p 123
} 
imediatamente ao ser atingido no meio de suas costas pelo dardo lançado pelo jovem" e foi morto "sem intenção") comunica a sua aparência. Ao final desses dois primeiros discursos pode-se afirmar que Antifonte apresenta dois $\lambda$ ó $\gamma o$ em disputa, com ambos

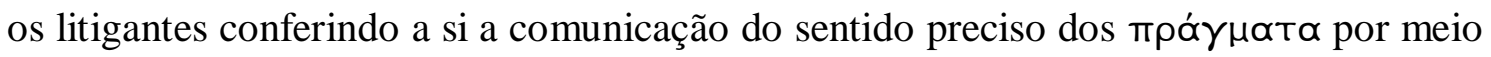
de seus $\lambda$ óyol.

O segundo discurso da acusação começa com a declaração de que a defesa tem dupla vantagem sobre ela: "ao ter oferecido um discurso de defesa contra um discurso meu e ao fazer sem risco de réplica as acusações que ela pronunciou" (3.3.2). É importante lembrar que a acusação fez apenas um breve discurso, sem desenvolver uma argumentação contra o réu, certamente acreditando que, como os fatos lhe eram claros, não haveria a réplica. Como houve um discurso de defesa, a acusação afirma, então, haver já uma vantagem para a defesa em relação ao argumento do discurso. No entanto, ela afirma haver outra vantagem, maior do que esta: em relação às ações que realizou

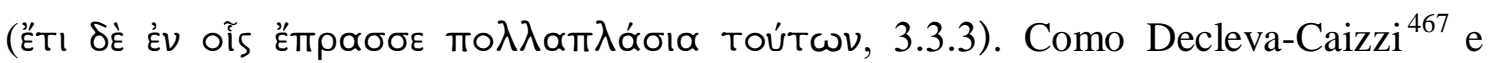
Gagarin $^{468}$ sugerem, mesmo que a única ação realizada pela defesa seja a de discursar, a inclusão de uma ação como a outra vantagem parece se referir à superioridade, em um sentido material, de um discurso longo e do desenvolvimento de uma argumentação, que poderão influenciar os resultados ao final do litígio. Como apresentado pela acusação, parece ficar subentendido que as palavras da defesa são em algum sentido também uma ação. Em sua interpretação dessa passagem, Gagarin ${ }^{469}$ acredita que essa é a primeira alusão de que $\lambda o ́ \gamma o$ e épya são não apenas correspondentes como, em algum sentido, idênticos, noção esta que também será aludida por Tucídides. Se não são idênticos, como sugere Gagarin, pode-se dizer, ao menos, que o $\lambda$ óyos pode "construir",

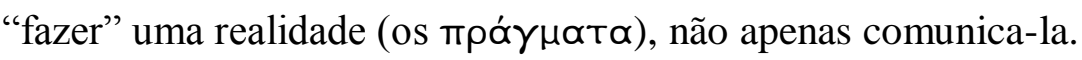

Buscando rebater a afirmação da defesa para quem os fatos não estão em disputa, mas é preciso interpretá-los, servindo-se, para isso, da ákpíßeı ("precisão" ou “sutileza”) para apresentar sua verdade (3.2.1-2), a acusação apela aos juízes que, "quando os fatos são claros, não sejam persuadidos pela perversa sutileza dos discursos

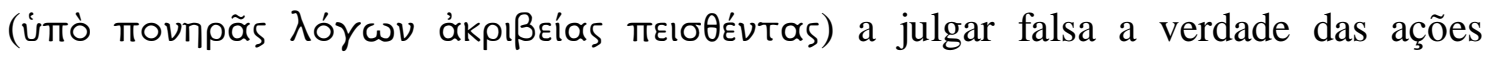

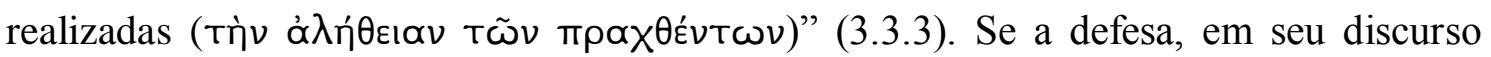

\footnotetext{
${ }^{467}$ ANTIPHONTIS, 1969, p. 223

${ }^{468}$ GAGARIN, 2002, p 124

${ }^{469}$ Ibid., p. 124
} 


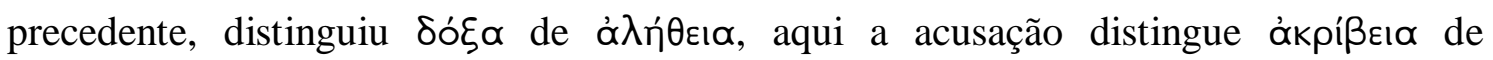
á $\lambda \hat{n} \theta \varepsilon ı \alpha$, sendo a primeira, como notou Decleva-Caizzi ${ }^{470}$, criadora do falso: "pois a

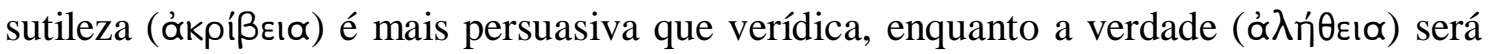
pronunciada com menos engano, mas também com menor eficácia persuasiva" (3.3.4). Nas palavras da acusação, a ớkpíßzı é, na maioria das vezes (se não sempre), apenas uma ferramenta para a falsa persuasão ${ }^{471}$; é criadora de míoteı (crenças) não verdadeiras $^{472}$; por outro lado, a á $\lambda \hat{\theta} \theta \varepsilon ı$ ๔ envolve menos engano, mas também menos poder para persuadir uma audiência. É interessante observar, como indica Gagarin ${ }^{473}$, que tanto a defesa quanto a acusação apresentam a ó $\lambda \hat{n} \theta \varepsilon \varepsilon$, ao menos no âmbito do tribunal, como desvantajosa em relação à ókpíßєıа: a defesa afirma ser obrigada a comunicar a verdade por meios extraordinários; a acusação afirma que a verdade é menos poderosa.

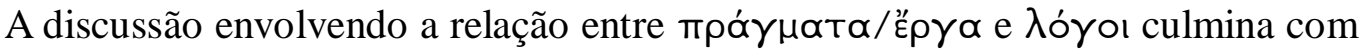
a declaração do defensor em seu último discurso. Em seu proêmio, ele ressalta inicialmente que cada um julga o assunto (Tò $\pi \rho \alpha ́ \gamma \mu \alpha)$ de modo favorável a si mesmo

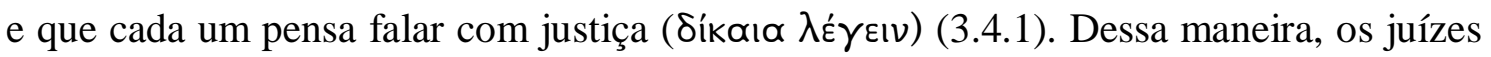
"têm o dever de observar de modo equânime (íows) as ações realizadas (Tờ

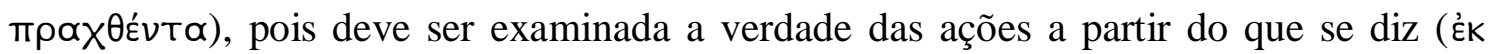

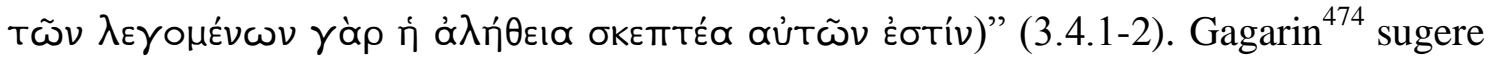
que essa admissão da predisposição natural de um litigante provavelmente não seria externada em um tribunal por litigantes e que, antes de servir como um meio de persuadir os juízes, hipotéticos nas Tetralogias, poderia expressar, segundo Gagarin, o ponto de vista de Antifonte sobre a linguagem, a verdade e a realidade. Se o autor expressa ou não sua visão sobre o assunto pela boca dos litigantes, a realidade é que a fala da defesa sobre o fato de que cada litigante julga o assunto de modo favorável a si

\footnotetext{
${ }^{470}$ ANTIPHONTIS, 1969, p. 224

${ }^{471}$ GAGARIN, 2002, p. 124

${ }^{472}$ ANTIPHONTIS, 1969 , p. 224
}

Decleva-Caizzi lembra que há uma discussão no diálogo Górgias de Platão (454 d-455a) em que a crença ou tíotıs é tratada como uma obra do orador. De fato, ela é apresentada como uma das duas espécies de persuasão (a outra é a persuasão que é fonte do conhecimento). A retórica nos tribunais e nas assembleias, de acordo com a discussão entre Sócrates e Górgias, vale-se da persuasão que é fonte de crença sem conhecimento. Sócrates conduz a conversa a ponto de, no final, a retórica ser tratada como obreira da persuasão que promove a crença - não o conhecimento - relativa ao justo e ao injusto, e o orador, ao contrário de instruir o tribunal e as assembleias acerca desses dois valores, apenas desperta a crença neles.

${ }^{473}$ GAGARIN, 2002, p. 124

${ }^{474}$ Ibid., p. 125 
mesmo e pensa dizer coisas justas implica dizer que cada litigante entenderá um

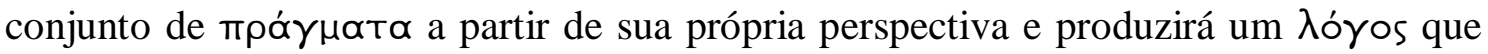

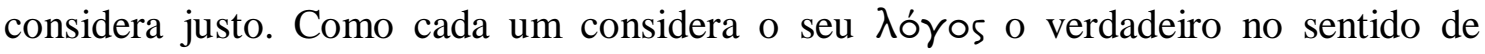
corresponder aos пра́) $\mu \alpha \tau \alpha$ em questão, caberá aos juízes determinar a verdade de

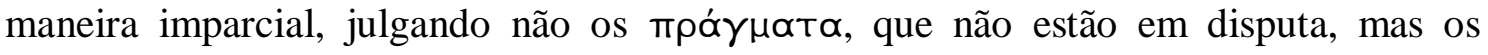
$\lambda$ óyol dos litigantes, que se opõem ao fornecer um relato distinto e uma interpretação diversa dos próprios пра́) $\mu \alpha$ та. Como a verdade dos fatos só pode ser determinada a

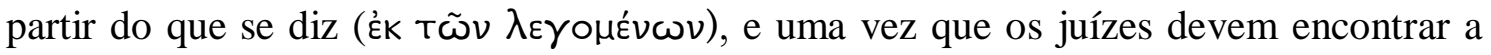
verdade nos $\lambda$ óyoı, eles, do ponto de vista da acusação, não devem ser prejudicados pela sutileza e precisão dos argumentos, que algumas vezes se mostram úteis e não necessariamente enganosos, como lembrará a defesa. Em outras palavras, a ớkpíßeı não necessariamente será uma ferramenta para a falsa persuasão, nem será criadora de Tíotєıs (crenças) não verdadeiras, como parece sugerir a defesa ao dizer que

"Eu, de minha parte, se tenho dito alguma mentira, concordo que também

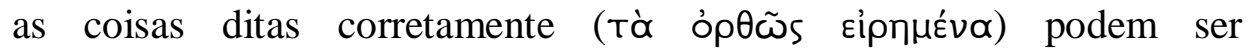
desacreditadas como sendo injustas; mas se tenho dito a verdade ( $\dot{\alpha} \lambda \eta \theta \tilde{\eta})$, mesmo com sutileza ( $\lambda \varepsilon \pi т \grave{\alpha})$ e precisão (ákpıßñ), não é justo que eu, que falo, mas sim o autor das ações, carregue o ódio dos argumentos da acusação" (3.4.2).

Além de reforçar que o seu $\lambda$ óyos é o verdadeiro e que, consequentemente, é o

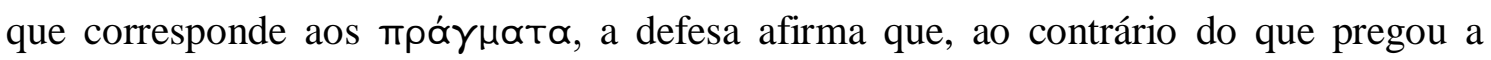

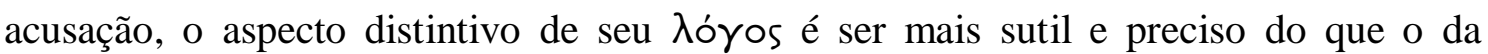
acusação, e que essas qualidades, ainda que potencialmente empregadas para a falsa persuasão, são usadas, por ela, defesa, em prol da verdade. Após dizer que o assassino é indicado não se alguém declarar ( фáokṇ) que ele matou, mas se alguém encontrar uma

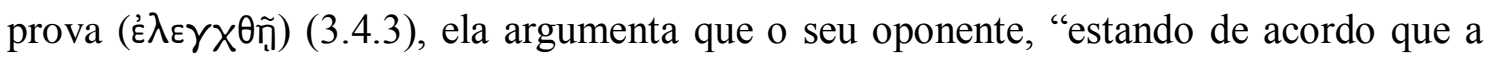

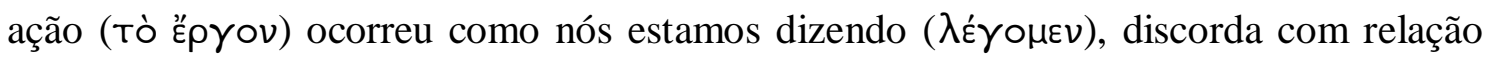
ao assassino, que é impossível de ser indicado de outro modo senão pelo que foi feito

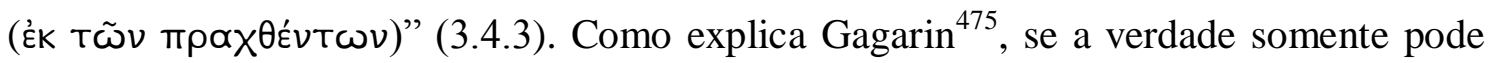
ser discernida a partir do que foi dito, e o assassino somente pode se indicado a partir do

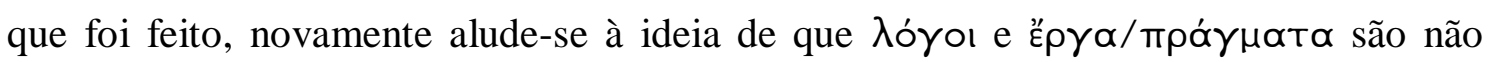

${ }^{475}$ GAGARIN, 2002, p. 126 
apenas correspondentes como, em algum sentido, idênticos. Ou seja, a complexa relação

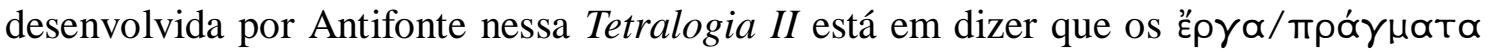
controlam os $\lambda$ ó $\gamma$ ol, mas estes também controlam aqueles, uma vez que a verdade dos fatos ou das ações dependem das palavras ou dos discursos que os representam. Desse modo, Gagarin acredita que, ao contrário de uma antítese ou de uma relação contrastante, na Tetralogia II a linguagem, em algum sentido, corresponde aos $\pi \rho \alpha ́ \gamma \mu \alpha \alpha^{476}$. Porém, tendo-se em vista que é difícil um conhecimento preciso dos

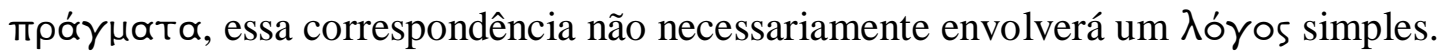

Essa análise entre linguagem e realidade e da complexa associação entre elas, encontra paralelos na obra de Tucídides. Como observa Parry ${ }^{477}$, toda a obra é dividida

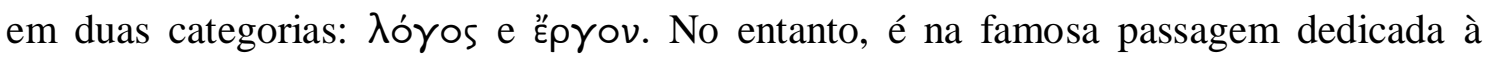
apresentação de seu método e de seu propósito ao escrever a obra (1.22) que se encontra um dado importante. Conforme tratado anteriormente, nessa passagem Tucídides reconhece a dificuldade de se adquirir informações precisas (ákpíßઘı $v$ ) sobre os eventos, pois muitas delas foram obtidas por meio de $\lambda$ ó $\gamma$ o pronunciados por outras pessoas. Ele afirma que os fatos que são relatados por ele são resultado de uma investigação minuciosa, feita com a maior precisão possível, e insiste que a apuração desses fatos foi tarefa difícil pela variação dos relatos acerca de um mesmo assunto, ou seja, houve uma grande dificuldade em alcançar a realidade das coisas. No entanto, diz que sua obra é útil para aqueles que buscam conhecer de modo claro os eventos ocorridos. De modo geral, pode-se deduzir do que é dito nessa apresentação

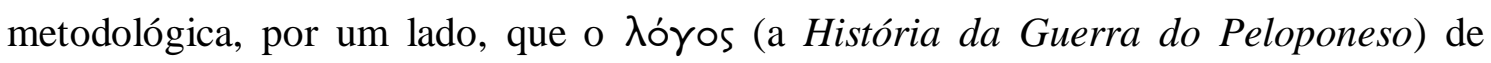

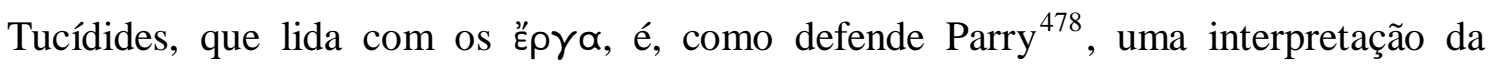
realidade que interpreta também as possibilidades de interpretação; por outro, que tudo

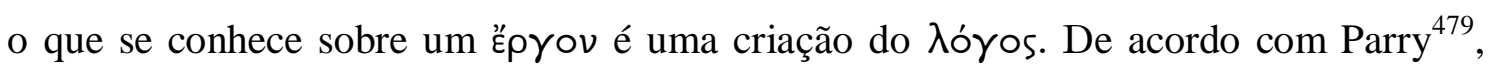
Tucídides não está falando de relatos de terceiros que concordam com a realidade, mas sim dos relatos que concordam um com os outros. Em outras palavras, Tucídides recolhe os relatos e através de uma investigação rigorosa chega à interpretação que lhe parece mais clara de como os eventos devem ter ocorrido. A implicação dessa afirmação,

\footnotetext{
${ }^{476}$ GAGARIN, 2002, p. 126

${ }^{477}$ PARRY, 1988, p. 7

${ }^{478}$ Ibid., p. 103

${ }^{479}$ Ibid., p. 103
} 
segundo Parry ${ }^{480}$, é que o que quer que seja conhecido acerca de um evento é amplamente uma criação da linguagem. Portanto, ainda que o $\lambda o ́ \gamma o s$ não seja o meio mais adequado para representar eventos da forma como aconteceram (Tucídides parece alertar para isso no início da oração fúnebre de Péricles - II. 35), ele é o único meio para

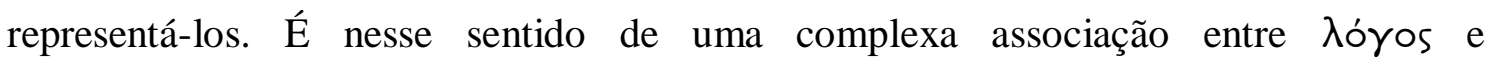

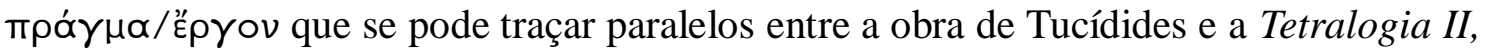
e também com Sobre o Não-Ser, de Górgias.

Em última análise, o que Antifonte desenvolve nessa Tetralogia II são dois

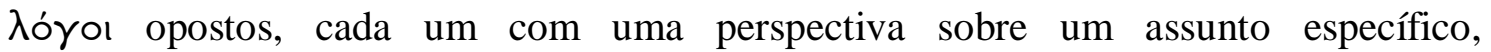
precisamente o princípio da antilogia. Ao final dessa discussão, uma conclusão não é explicitamente apresentada. O mesmo para a complexa questão da causa e da responsabilidade. Gagarin, contudo, está predisposto não apenas a ver a declaração da

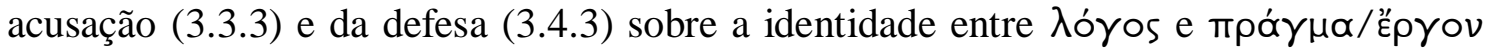
como a posição efetiva de Antifonte ${ }^{481} \mathrm{e}$, sobretudo, de como deveria ser a base para decisões judiciais ${ }^{482}$, como acredita que, implicitamente, uma conclusão pretendida por Antifonte acerca da ókpíßєı̊ poderia ser a de que o relato mais preciso é melhor (ou mais forte) do que um menos preciso ${ }^{483}$. Mas, explicitamente, Antifonte não apresenta uma conclusão com relação a isso. Na ausência de um veredito, a decisão entre os dois relatos permanece sem resposta.

\subsubsection{O miasma}

Por fim, outro aspecto importante na Tetralogia II é a questão do miasma decorrente do derramamento de sangue. Embora menos desenvolvida em comparação com as outras Tetralogias, ela é utilizada por Antifonte para a construção dos discursos dos dois litigantes. Aqui, como nas demais Tetralogias, houve uma morte por assassinato. Por se tratar de um homicídio não-intencional, a pena será reduzida em comparação a um caso de homicídio intencional, mas não se elimina a necessidade de reparação ao morto. Um argumento comum aos dois litigantes é que o morto se tornará um espírito vingativo (тробтрóт๙ıь) caso nada seja feito. Como foi visto no primeiro

\footnotetext{
${ }^{480}$ PARRY, 1988, p. 103

${ }^{481}$ GAGARIN, 2002, p. 126

${ }^{482}$ Ibid., p. 126

${ }^{483}$ Ibid., p. 126
} 
capítulo, é uma visão típica das Tetralogias que o morto se torne um пробтрóтঞ๙ıs, caso não receba a expiação adequada, como também é uma visão comum que os litigantes lancem sobre os juízes a cólera do morto, responsabilizando-os caso o culpado seja absolvido. Em um caso de tribunal, a reparação seria realizada com o exílio do assassino. Mas, como se sabe, Antifonte não fornece um veredito para o caso. Gernet sugere que, se um veredito fosse dado, o jovem acusado seria absolvido ao final da disputa e uma purificação seria suficiente ${ }^{484}$.

Na Tetralogia II a questão do miasma é construída da seguinte maneira:

No proêmio do primeiro discurso da acusação (3.1.2), em uma sentença omitida

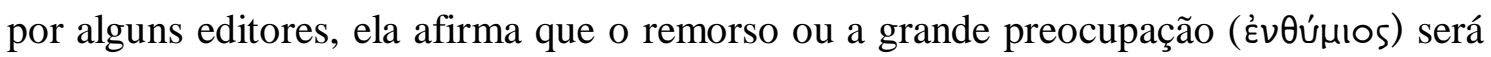
dos vivos, e pede aos juízes que, tendo piedade dos pais, expulsem o assassino dos

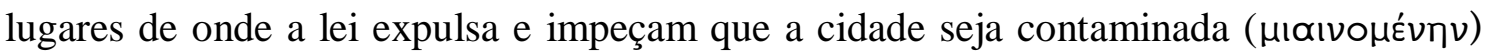
pelo assassino. A lei em questão diz respeito à exclusão do assassino dos lugares públicos e religiosos, a fim de evitar a contaminação da cidade com sua presença.

A defesa, no epílogo de seu discurso (3.2.11-12), não menciona nada sobre o espírito sem vingança do morto nem sobre a contaminação da cidade; apenas se dirige aos juízes clamando piedade para o filho, que não agiu nem injusta nem impiamente. A piedade e a justiça (őఠıov kaì Síkaııv), como já mencionado, serão um par comum nas Tetralogias, o que indicaria uma estreita conexão entre as esferas divina e humana, outro tema central desses discursos de Antifonte.

A acusação em seu último discurso argumenta no epílogo (3.3.11-12) que o jovem, sendo partícipe do homicídio, pois atirou a lança, não deve ser absolvido pelos juízes, pois nem o morto nem o pai, que é quem faz a acusação, serão tratados de forma piedosa pelos que julgam o caso se o garoto for considerado o autor da própria morte, nem o assassino absolvido, se não for expulso dos lugares de onde a lei expulsa. A acusação alerta os juízes para o risco da mancha de sangue ou impureza decorrente do homicídio ( $k \eta \lambda i s)$ recair sobre eles e afirma a eles que, por um lado, ficarão livres da mancha caso condenem o jovem e o expulsem dos lugares de onde a lei expulsa, mas, por outro lado, serão responsabilizados, ou seja, terão a mancha de sangue caso o absolvam. De acordo com a piedade e a justiça, os juízes devem, portanto, punir o jovem.

${ }^{484}$ ANTIPHON, 1954, p. 69. 
No epílogo do último discurso da defesa (3.4.9), ela lembra que a vítima assassinou a si mesma. Logo, o assassino foi punido e não se pode dizer que não houve vingança. Para a defesa, enquanto o garoto não deixará para ninguém o seu espírito vingativo (тробтро́таıо), pois foi ele quem errou contra si mesmo, o jovem deixará para seus condenadores algo maior que um peso sobre suas consciências ou uma

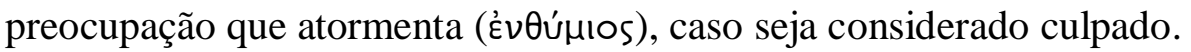

\subsection{Comentário da Tetralogia III}

O caso hipotético tratado nesta ultima Tetralogia diz respeito à morte resultante de uma briga envolvendo um jovem e um velho. Os dois, supostamente bêbados, lutaram entre si e o velho morreu em decorrência dos ferimentos da agressão "alguns dias mais tarde" após ser atendido por um médico. Em um tribunal hipotético, enquanto a acusação será feita pelos parentes da vítima, a defesa será feita, inicialmente, pelo próprio acusado e, em um segundo momento, por um amigo do réu.

Como na Tetralogia II, os fatos não estão em disputa, mas são aceitos por ambos os litigantes: trata-se de uma morte resultante de uma briga. Entretanto, a Tetralogia III fornece um cenário mais complexo em comparação não apenas com a $I I$, mas também com a $I$, fazendo alusão a alguns pontos tratados nesses dois discursos. Entre outros assuntos, o que se discute aqui são as intenções dos dois homens e a responsabilidade, sobretudo, do velho por sua própria morte. O foco principal da Tetralogia III será direcionado, em grande parte, à investigação da causa do homicídio. Os argumentos apresentados, contudo, são diferentes dos encontrados, por exemplo, na Tetralogia II, que também lida com a questão da causa e da responsabilidade. Ademais, ao contrário dos outros discursos, Antifonte introduz um terceiro agente como possível responsável: o médico que atendeu a vítima antes de ela morrer. Em um cenário hipotético bastante complexo criado para essa Tetralogia, Antifonte apresenta também uma interessante discussão acerca da relação envolvendo vómos e qúoıs, e alude brevemente ao

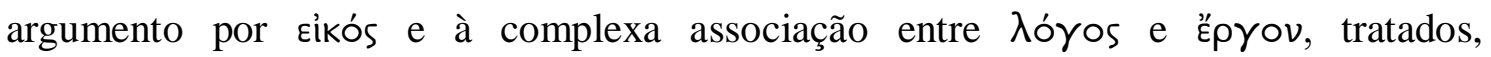
respectivamente, nas Tetralogias I e II.

Em primeiro lugar, um problema a ser ressaltado é a natureza do caso. Com frequência, estabelece-se que o caso da Tetralogia III é o de um homicídio em legítima 
defesa ou justificável (фóvos kató toùs vómous ou Síkaıı) e que, portanto, seria julgado no Delfínio. Tendo em vista que a Tetralogia I levanta a possibilidade de ser um caso de homicídio intencional (фóvos Ékoúoıos) ${ }^{485}$, de competência do Areópago, e que a Tetralogia II lidaria com um caso de homicídio não-intencional (фóvos ớkoúoı๐s) ${ }^{486}$, de competência do Paládio, acreditou-se que, sendo o caso da Tetralogia III o de homicídio justificável ou em legítima defesa, haveria uma correspondência entre os três discursos que constituem as Tetralogias e os três principais tipos de casos de homicídio do sistema legal ateniense. No entanto, como visto em 1.2, essa visão não parece tão simples, dentre outras razões, porque apenas em circunstâncias específicas a pessoa que cometeu um assassinato justificável ou em legítima defesa era absolvida imediatamente. O que se discute na Tetralogia III é se houve ou não intenção de matar: a acusação baseia seus argumentos, em um primeiro momento, na intencionalidade ou premeditação do crime e, em um segundo momento, na possibilidade de ter sido uma morte não-intencional, mas jamais trata o caso como um homicídio justificável. Quanto ao réu (e em certo momento, um amigo), ainda que avente a possibilidade de ter agido em legítima defesa - repelindo um golpe com outro golpe - ele busca, acima de tudo, se eximir de qualquer responsabilidade pela morte. Gagarin sugere que o caso desenvolvido aqui, se fosse apresentado em um tribunal, muito provavelmente seria julgado como homicídio intencional no Areópago, pois ainda que a vítima tivesse começado a briga, isso favoreceria uma defesa contra homicídio intencional, mas não se converteria automaticamente em homicídio justificável ${ }^{487}$. Vale lembrar, ainda, que o homicídio intencional incluía assassinato com intenção de fazer algum mal ou de lesar alguém, não apenas com intenção de matar.

\subsubsection{Da disposição dos discursos}

De todas as Tetralogias, a III é visivelmente a mais curta. De modo similar aos outros discursos, os proêmios e os epílogos, em sua maioria, são dedicados à exposição de uma crença religiosa do miasma. Assim como na Tetralogia II, um breve resumo do caso é dado no primeiro discurso da acusação: “(...) estando o jovem embriagado, por

\footnotetext{
${ }^{485} \mathrm{Na}$ realidade, a acusação defende a premeditação do crime, mas os fatos não são claros. Não seria correto, portanto, definir o caso como sendo de homicídio intencional.

${ }^{486}$ De fato, ambos os litigantes concordam se tratar de um caso de homicídio não intencional.

${ }^{487}$ GAGARIN, 1998, p. 40
} 
desmedida e por falta de auto-controle, espancou e estrangulou o velho até que lhe privasse da vida; (...)" (4.1.6). Entretanto, o que chama bastante a atenção na construção dessa Tetralogia é o uso, por parte de Antifonte, de um procedimento permitido pela lei ateniense: o exílio voluntário. De acordo com a lei ateniense, o defensor realmente poderia se retirar para o exílio antes de seu segundo discurso, que ficaria a cargo de algum parente ou amigo. No caso da Tetralogia III, o abandono do tribunal e a opção pelo exílio pode sugerir, à primeira vista, que o discurso da defesa seja mais fraco que o da acusação ou, então, expressar a falta de confiança do réu em persuadir os juízes, em contraste com a confiança dos acusadores ("O acusado, não porque se considerou culpado, mas porque ficou aterrorizado com a veemência dos acusadores, retirou-se para o exílio" - 4.4.1). O fato é que, certamente, tal escolha influenciaria os juízes a dar um veredito favorável à acusação. Como nos demais discursos, um veredito não é fornecido, mas talvez não fosse favorável à defesa. Pode-se supor, contudo, que a construção do caso com a partida para o exílio do acusado poderia permitir a Antifonte explorar alguns argumentos que essa situação possibilitaria desenvolver.

Quanto à estrutura, a Tetralogia III poderia, de maneira ilustrativa, ser apresentada do seguinte modo:

\section{Primeiro discurso da acusação (4.1)}

Proêmio (1-5): desenvolvimento de um mito da criação do homem e ênfase na tese de que um homicídio é uma ofensa contra os deuses e uma violação das normas estabelecidas pelos homens. A acusação reconhece que está sujeita às penas do homicídio se um inocente for equivocadamente acusado e condenado, e aconselha os juízes a condenarem o culpado para que a cidade não seja contaminada.

Argumentação e narrativa (6): breve declaração dos fatos. A acusação sustenta que o réu matou, estando embriagado e agindo desmedidamente e sem auto-controle.

Epílogo (7): A acusação resume o caso e declara que o crime foi deliberado.

\section{Primeiro discurso da defesa (4.2)}

Proêmio (1): a defesa resume o caso: a vítima, embriagada, é a responsável pela própria morte, pois começou a briga.

Argumentação (2-6): a defesa apresenta os eventos como uma sequência causal: seu golpe foi a causa imediata da morte, o golpe inicial da vítima a causa principal e o 
atendimento médico a causa determinante. A defesa acrescenta que apenas se defendeu daquele que começou a agressão e que não planejou a morte.

Epílogo (7-9): o réu alega que seus acusadores buscam matá-lo e retoma a mesma conexão entre os aspectos divino e humano do proêmio do primeiro discurso da acusação. Ele pede aos juízes que julguem com justiça.

\section{Segundo discurso da acusação (4.3)}

Proêmio (1): considerações sobre o discurso anterior do réu.

Argumentação (2-5): a acusação busca refutar os vários argumentos da defesa: reforça a tese de premeditação do crime; emprega um argumento baseado no Eikós; contra-argumenta acerca da responsabilidade do médico e dos próprios acusadores na morte.

Epílogo (6-7): a acusação reforça que a agressão do réu causou a morte e implora aos juízes que livrem a cidade da impureza.

\section{Segundo discurso da defesa (4.4)}

Proêmio (1): declaração de um amigo do réu da retirada do mesmo para o exílio.

Argumentação (2-9): A defesa retoma os argumentos elaborados no primeiro discurso pelo réu e rebate o argumento baseado no Eíkós. Um novo argumento é acrescentado: na ausência de provas claras, é mais justo que o réu seja absolvido que condenado.

Epílogo (10-11): A defesa pede aos juízes que não condenem um inocente e reforça a ameaça do miasma

\subsubsection{A intenção, a causa e a responsabilidade}

De modo similar à Tetralogia II, o primeiro discurso da acusação é mais curto e, nele, o argumento é minimamente desenvolvido. Uma breve narrativa é mesclada ao argumento. Após um proêmio mais longo do que o normal (4.1.1-5), em que se elabora uma interessante conexão entre as esferas humana e divina a partir de um mito da criação do homem, a acusação sustenta que o homicídio foi intencional (4.1.6). Ecoando 
a fala da acusação na Tetralogia II (3.2.3), afirma que o réu, embriagado, agiu sob

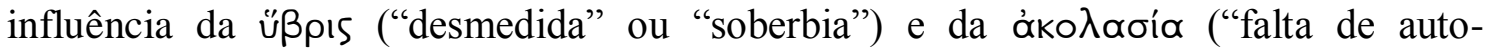
controle"). Mas diferentemente da Tetralogia II, aqui são atribuídos ao jovem os dois comportamentos, não um ou o outro. Além do mais, a eles acrescenta-se o estado de embriaguez. É interessante notar que a embriaguez também foi mencionada pela acusação na Tetralogia I (2.1.4) como sendo uma dentre várias situações que podem levar alguém a praticar um crime e é de se imaginar que, ao contrário de uma morte durante uma competição atlética, uma briga entre duas pessoas embriagadas não deveria ser incomum aos gregos do período ${ }^{488}$, como não o é ainda hoje para nós. Com relação à sua importância na argumentação, Gagarin menciona uma passagem da Ética a Nicômaco $(3.5,1113 b 30-3)$ de Aristóteles, em que o filósofo examina a noção de ato intencional e ato não-intencional, para sugerir que a embriaguez não daria ao caso um caráter de ação não-intencional $^{489}$. A análise de Aristóteles é interessante pois, em um determinado momento, ele menciona que estão em nosso poder e são intencionais “aquelas coisas cujos princípios estão em nós" (ZINGANO, 2008, p. 71). Dão testemunhos em favor disso, segundo o filósofo, os atos privados dos homens comuns e dos próprios legisladores. Assim, castigos e punições são aplicados "aos que cometem vilanias que não tenham agido forçados ou por ignorância da qual eles próprios não foram responsáveis" (Ibid., p. 71). Penalidades, prossegue Aristóteles, também são aplicadas "pelo fato mesmo de ignorar, quando parece que se é responsável pela ignorância; por exemplo, as penas são dobradas para os embriagados" (Ibid., p. 71), pois o princípio da embriaguez está no embriagado, que é “senhor do não se embriagar, o que foi a causa da ignorância" (Ibid., p. 71). Sendo a embriaguez um ato intencional, pois está em poder do embriagado não se embriagar, e a ação de se embriagar foi a causa de sua ignorância, não se elimina ou diminui a responsabilidade daquele que se embriagou caso venha a cometer um homicídio nessas condições.

O primeiro discurso da acusação é encerrado com duas informações importantes: a menção da existência de testemunhas ( $\tau \tilde{\omega} \nu$ $\mu \alpha \rho \tau u ́ p \omega \nu)$, que estavam com o réu quando ele estava bêbado, e que foram ouvidas pelos juízes (4.1.7); e o pedido de

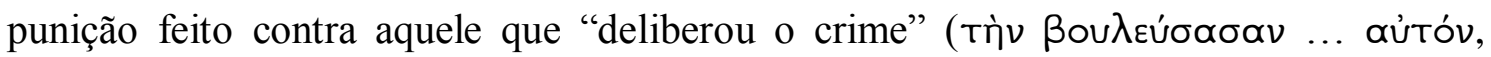

\footnotetext{
${ }^{488}$ Um caso análogo é mencionado por Demóstenes no discurso Contra Mídias (21.73-5). Nele, é mencionado que um homem embriagado assassinou outro que o golpeara primeiro. $\mathrm{O}$ assassino foi absolvido por um voto.

${ }^{489}$ ANTIPHON, 1997, p. 164
} 
4.1.7). Esta última afirmação reforça o interesse da acusação em sustentar a premeditação do assassinato. Com relação às testemunhas, tudo indica que não são escravos, como na Tetralogia I, mas homens livres. A interferência delas não é sentida no texto senão nas referências da acusação e da defesa àqueles que testemunharam a briga. Porém, como ficará claro ao final da disputa, ambos os litigantes afirmam que as testemunhas lhes são favoráveis $(4.1 .3,4.4 .3,4.4 .8)$, não contribuindo de modo decisivo para fortalecer os argumentos de nenhum dos lados.

A defesa, por sua vez, começa seu primeiro discurso à maneira da defesa na Tetralogia II, ou seja, transferindo a responsabilidade para o próprio morto: “o morto, mais do que eu, foi o próprio responsável" (4.2.1). Mas, ao contrário do que ocorre naquela, o réu não se exime totalmente da culpa, apenas argumenta que a vítima,

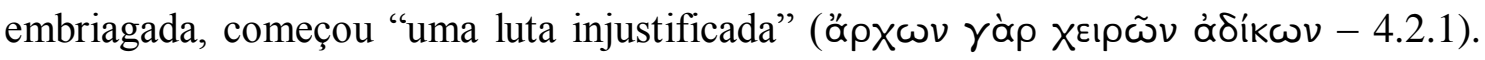
Se a acusação mencionou em seu discurso que o réu estava embriagado, agora é a vez da defesa destacar que o morto também estava. Como nenhum dos lados da disputa nega este fato, tudo indica que ambos realmente estavam embriagados. Nesse discurso da defesa, a argumentação central consiste em sustentar que aquele que começou uma luta deve ser o responsável pelas consequências: ainda que o acusado tivesse se defendido dos golpes sofridos de modo mais severo do que os golpes iniciais do agressor, ele não teria agido ilegalmente, pois "os que começam a agressão são merecedores de sofrer em troca não só esse castigo, mas maiores e mais em umerosos" (4.2.2); e não teria se defendido se não tivesse sido atacado pelo velho (4.2.6). Antecipando um possível argumento de seu oponente, o réu menciona que a acusação

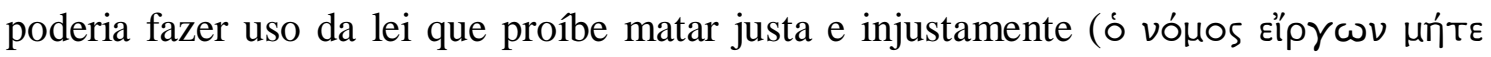

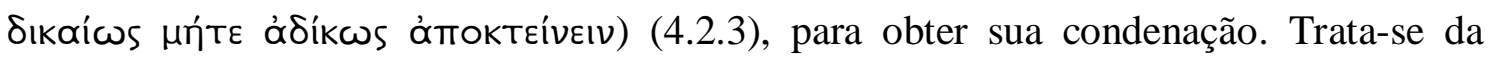
mesma lei mencionada na Tetralogia II, e, de modo similar ao procedimento da defesa naquele discurso, ela é inserida, aqui, para insistir com os juízes que o acusado não assassinou o velho, caso contrário, ele entende que estaria sujeito às penas do homicídio $^{490}$.

\footnotetext{
${ }^{490}$ Como observado na nota 245, essa lei é mencionada na Tetralogia II por ambos os litigantes (3.2.9 e 3.3.7), inicialmente pela defesa, e, nesta Tetralogia, apenas pela defesa (4.2.3 e 4.4.8). É curioso que justamente a defesa introduza uma lei que, aparentemente, lhe será desfavorável, enquanto é omitida pela acusação, que mais teria motivo para mencioná-la. É interessante notar, contudo, que, sobretudo na Tetralogia III, essa lei parece ser declarada pela defesa pelo ponto de vista de uma crença religiosa: o assassinato, de qualquer tipo, é um ato de impiedade contra os deuses. Tal declaração serviria de contraponto à declaração da acusação no proêmio do primeiro discurso que, baseada em uma crença
} 
A defesa, como observa Gagarin ${ }^{491}$, constrói seu discurso apresentando os eventos como uma sequência causal em que seu golpe foi a causa imediata da morte, mas o golpe inicial da vítima foi a causa principal. Primeiro, ela argumenta que, "se o velho tivesse morrido imediatamente pelos golpes, ele teria morrido por minhas mãos, sim, mas de modo justo", visto que o velho começou a luta (4.2.3). Nessa passagem, ela não diz, contudo, que foi um assassinato justificável, mas que sequer matou. Dito isso, acrescenta um dado novo: um médico incompetente é o responsável pela morte do velho. De fato, o réu não se exime completamente da responsabilidade, mas a causa determinante, segundo ele, foi a péssima qualidade do atendimento médico recebido pelo velho após a briga. O que parece interessar à defesa é, sobretudo, remover de si a responsabilidade pela morte, transferindo-a para um terceiro agente. Ela procede, primeiro, afirmando que "se o morto foi entregue alguns dias mais tarde aos cuidados de um médico incompetente, ele morreu por causa da incompetência do médico e não por causa dos golpes" (4.2.4), que, conforme dito por ela mesma na sequência, não causaram ferimentos graves ("sendo curável sua ferida" - 4.2.4). Desse modo, o médico é apresentado por ela como o verdadeiro culpado pela morte. No entanto, não seria o único: também aqueles que aconselharam a vítima a buscar os cuidados de um médico incompetente poderiam ser considerados a causa da morte, pois teriam sido alertados por outros médicos que, se assim o fizessem, o velho morreria (4.2.4). Em última análise, seu golpe apenas obrigou a vítima a procurar um médico. Desse modo, para utilizar os termos empregados por Gagarin em sua análise, seu golpe foi a causa imediata da morte; a causa primeira é a própria vítima; a causa subsequente são os companheiros da vítima; e a causa determinante é o médico que a atendeu. Entretanto, como será mencionado no segundo discurso da acusação (4.3.5), há uma lei ${ }^{492}$ que estabelece que o médico não pode ser incriminado pela morte de um paciente. Apesar dessa impossibilidade de o médico sofrer punições pela morte do velho, está em questão

religiosa, menciona que aquele que mata alguém transgride as ordens divinas, visto que o ser humano é criação da divindade. Talvez essa lei possa ser melhor compreendida tendo-se em vista precisamente esse aspecto religioso, evidente também na elaboração de uma crença do miasma mais elaborada do que em outros textos. Não significa afirmar, contudo, que o autor das Tetralogias é influenciado por uma mentalidade religiosa arcaica, mas que, como observou Gagarin, desenvolve uma declaração moral provocativa fruto das experimentações intelectuais da segunda metade do século V a.C. (ANTPHON, 1997, p. 24).

${ }^{491}$ GAGARIN, 2002, p.128

492 Cf. Platão, Leis IX, 865 B 
para o réu precisamente a remoção de sua responsabilidade pela morte, lançando-a para outra pessoa.

Por fim, o réu apresenta três outras considerações com o objetivo de transferir a responsabilidade para a vítima e persuadir os juízes a absolvê-lo: ele não tramou o assassinato (4.2.5) como afirma a acusação em 4.1.7; o morto foi vitimado ou por seu próprio infortúnio (átuXía), pois calhou de começar a agressão (4.2.6), ou por sua própria imprudência (åßou入ía), pois não raciocinou bem ao atacá-lo (4.2.6). Mas essas considerações são apenas brevemente discutidas.

É possível também fazer um paralelo entre a questão da causa e da responsabilidade analisada na Tetralogia II e neste discurso. Enquanto naquela dois eventos simultâneos, mas independentes (o lançamento do jovem e o avanço do garoto), se unem para produzir um resultado (a morte), na Tetralogia III, de acordo com a alegação da defesa, um evento (o golpe inicial da vítima) causou um evento subsequente (o golpe da defesa como resposta), que produziu um resultado (a morte). A base da argumentação da defesa, no primeiro caso, é que aquele que errou é o culpado; no segundo, a culpa é daquele que iniciou a sequência de eventos ${ }^{493}$.

A réplica da acusação, por sua vez, tem início com ela expressando incredulidade com relação ao que foi argumentado pelo réu no discurso precedente, em que admitiu ter dado ao velho "os golpes pelos quais ele morreu" (4.3.1), mas, ao mesmo tempo, afirmou "que não é o assassino da vítima" (4.3.1); em contrapartida, atribuiu aos acusadores a responsabilidade pela morte (4.3.1). Essa incredulidade posteriormente será reforçada no epílogo (4.3.6-7). A acusação, portanto, se concentrará em rebater os outros pontos argumentados pela defesa. Em primeiro lugar, contra a afirmação de que o morto começou a agressão e que, por esse motivo, seria o próprio responsável, a acusação não acena para os testemunhos, mas procede utilizando o argumento do عíkós:

“(...) é mais plausível (عíkótepóv) que os mais jovens e não os mais velhos comecem uma agressão e fiquem embriagados, pois enquanto, aos primeiros, a arrogância natural, a plenitude da força física e a falta de perícia com os excessos de bebida os incitam a ceder à cólera, aos últimos a experiência com os excessos de bebida, a debilidade da velhice e o temor pela força dos jovens os fazem moderados." (4.3.2)

${ }^{493}$ GAGARIN, 2002, p. 128 
Entretanto, ao contrário do que ocorre na Tetralogia I, o Eíkós não terá um papel determinante nesse caso, pois é dito, por ambos os lados, que testemunhas presenciaram o fato e que confirmaram - informação apenas mencionada pelo defensor e omitida pelo acusador - que o velho começou a agressão (4.4.3). A fraqueza do Eiḱsós poderá ser notada na réplica da defesa no discurso seguinte:

"Ora, o acusador, ao não fazer uso de evidências plausíveis (Eikóoı

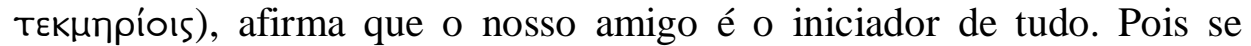
fosse a lei da natureza (кaтò qúoıv) que, assim como os olhos veem e os ouvidos ouvem, os jovens não tenham controle e os velhos sejam moderados, não seria necessário o julgamento dos senhores, pois a própria idade dos jovens os condenaria. Agora, sendo muitos os jovens moderados e muitos os velhos que se entregam aos excessos quando se embriagam, a evidência não vem a ser mais favorável ao acusador que ao acusado. [3] E sendo essa evidência comum tanto para nós como para o

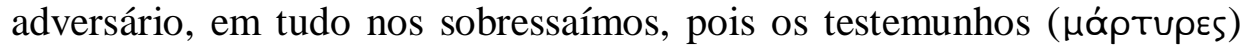
afirmam que a vítima começou a agressão.” (4.4.2-3)

Na Tetralogia III, o argumento do Eíkós é contrastado não apenas com a evidência direta do testemunho, mas também com aquelas coisas que por natureza são necessárias a todos os homens. Nessa passagem fica claro que uma regra que é baseada no que é razoável ou plausível não é a mesma coisa que uma regra da natureza: é plausível que um jovem comece uma briga com um velho, mas essa afirmação tem um status diferente do que a regra segundo a qual nós vemos com nossos olhos; pode haver casos em que um velho comece a briga, mas não que nós vejamos com nossos ouvidos. Aqui, ficariam evidentes as dificuldades do uso do Eikós quando contraposto às evidências. E a própria acusação parece perceber isso, visto que abandona esse tipo de argumento logo em seguida. Gagarin ${ }^{494}$ sugere que o objetivo de Antifonte em novamente trazer à discussão o argumento do eíkós talvez seja reforçar o que foi explicitado na Tetralogia I, de que esse argumento somente tem força na ausência da evidência direta ${ }^{495}$. E, de fato, a acusação repentinamente passa a se dedicar a outros argumentos: o da intensidade do golpe (4.3.3) e o da premeditação da morte (4.3.4). No primeiro, procura distinguir o golpe inicial da vítima e o golpe em retaliação do réu com base no resultado final: apenas o segundo golpe causou a morte, havendo, portanto, uma desproporcionalidade entre eles. No segundo, procura distinguir a intenção da vítima e a

${ }^{494}$ GAGARIN, 2002, p. 129

${ }^{495}$ Ibid., p. 130 
do réu: "aquele que desferiu os golpes e não matou apenas planejou a agressão" (4.3.4); "aquele que espancou mortalmente planejou a morte" (4.3.4). Como destaca Gagarin ${ }^{496}$, esses argumentos não transformam o caso da acusação em um caso mais forte ao diferenciar as ações das duas partes, mas o interesse dos acusadores não parece ser o de provar a completa inocência da vítima, apenas o de provar que o réu tem responsabilidade na morte, ainda que parcialmente, e ainda que, conforme as palavras da própria acusação, tenha matado "quem não desejava matar" (4.3.4). Modificando o que havia declarado antes (4.1.7), a acusação,curiosamente, admite agora que pode não ter sido intenção do réu assassinar a vítima. Mas isso não significa que não tenha agido com violência e não mereça ser punido pela morte.

Por fim, a acusação rebate o argumento segundo o qual o velho foi morto pelas mãos do médico e também pelas mãos dos acusadores que o aconselharam a buscar tratamento com o médico, duas das causas da morte referidas pela defesa. No primeiro caso, a lei que absolve os médicos da responsabilidade pela morte de um paciente é mencionada (4.3.5); no segundo, não houve negligência por parte dos que aconselharam o homem ferido a buscar tratamento; logo, não devem ser considerados responsáveis (4.3.5). Em contrapartida, a responsabilidade deve recair sobre aquele que os forçou a buscar a ajuda de um médico. Atentando, sobretudo, para a causa primeira, a acusação argumenta que, uma vez que o golpe do réu forçou a vítima a precisar de cuidados médicos, aquele que desferiu o golpe deve ser o assassino.

Tendo o réu partido para o exílio antes do seu segundo discurso, a réplica, aparentemente, fica a cargo de um amigo. Seu discurso, inicialmente, procura rebater as evidências com base no Eíkós apresentadas pelo acusador (4.4.2), enfatizando que os testemunhos podem confirmar que a vítima começou a agressão (4.4.3). Essa declaração é interessante, pois, como foi dito acima, confirma as dificuldades do uso dos argumentos baseados no Eíkós quando contrapostos às evidências diretas. Em seguida, retoma a sequência de causalidade que o réu havia estabelecido em seu primeiro discurso:

“(...) se o agressor (ou seja, o acusado), por causa do golpe que os obrigou a recorrer a um médico, é o assassino mais do que o autor da morte (ou seja, o médico), então aquele que começou a agressão (no caso, o morto) vem a ser o assassino. Pois forçou um que estava em posição de

${ }^{496}$ GAGARIN, 2002, p. 130 
defesa a dar o contragolpe e ao golpeado, no caso o morto, a recorrer à ajuda de um médico. $\mathrm{O}$ acusado sofreria ações ímpias se, sem ter matado, fosse declarado assassino no lugar de quem realmente matou (o médico), e, sem ter começado, no lugar daquele que começou a agressão ( $o$ morto)." (4.4.3)

A defesa move a responsabilidade daquele que se defendeu da agressão (o acusado), para aquele que iniciou a agressão (a vítima), passando pelo autor efetivo da morte (o médico). Em outras palavras, a defesa transfere a responsabilidade primeiro para o médico, e, em seguida, para o morto. Em última análise, reforça-se o interesse dela de que o acusado não seja a causa principal do homicídio.

Outros argumentos, então, são retomados na sequência: o acusado não planejou matar, apenas desferir os golpes (4.4.4); de certo modo, errou ao revidar, ainda que sem intenção de matar (4.4.4); no entanto, o erro maior pertence a quem começou a agressão mais do que àquele que se defendeu (4.4.5), pois o velho agiu embriagado e sob influência da ǔßpıs, enquanto o jovem agiu apenas visando repelir os golpes (4.4.6); e o acusado não cometeu efetivamente uma agressão, pois se defendeu dos golpes de modo menos intenso do que merecia o agressor, que tudo fez e não se defendeu (4.4.6);

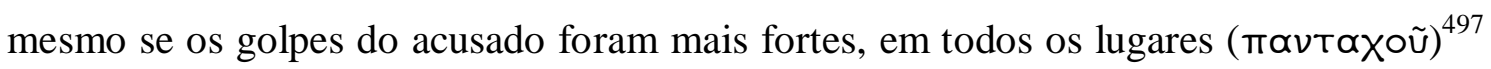
estabelece-se que aquele que inicia uma agressão deve ser punido (4.4.7); como o velho morreu por culpa do médico e não dos golpes - os testemunhos podem confirmar (c่s oí

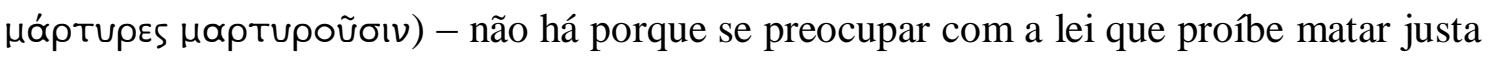
e injustamente (4.4.8). Ao final do discurso, a defesa fornece um argumento novo: se, diante do que foi apresentado, “o acusado não é merecedor de absolvição mais do que de condenação, também assim é justo absolvê-lo mais do que condená-lo" (4.4.9). Ou seja, se, ao final do litígio, ambas as partes são consideradas, em maior ou menor medida, responsáveis pela morte e se o réu é considerado tanto culpado quanto inocente, convém aos juízes absolvê-lo mais do que condená-lo. Como nota Gagarin ${ }^{498}$, o defensor na Tetralogia I havia argumentado que apenas deveria ser considerado culpado se ficasse provado que ele assassinou de fato, não de acordo com os argumentos do Eíkós: “Assim, nenhuma das coisas de que ele me acusa é convincente. Ser, então,

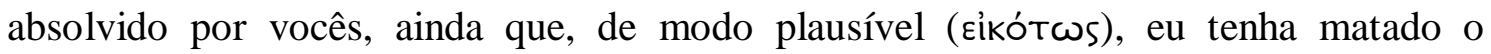

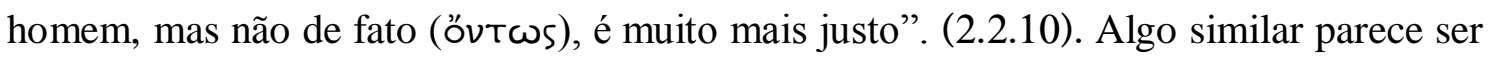

\footnotetext{
${ }^{497}$ Provavelmente referindo-se às cidades gregas.

${ }^{498}$ GAGARIN, 2002, p. 131
} 
feito aqui, quando a defesa afirma que, como não se provou claramente a culpabilidade do réu, ele deveria ser absolvido.

O caso, como nas outras Tetralogias, não nos fornece uma conclusão, ainda que se avente a possibilidade de o discurso da acusação ser mais forte que o da defesa, pela forma como o caso se desenrola. Porém, talvez seja mais interessante pensar que Antifonte elabora para esse discurso um cenário mais complexo do que o encontrado nas Tetralogias I ou II, recuperando sobretudo assuntos tratados anteriormente nesses dois discursos, sem focar em apenas um especificamente.

Com efeito, embora a Tetralogia III se concentre em grande medida na discussão acerca da intencionalidade, da causa e da responsabilidade, ela retoma, ainda que brevemente, a questão amplamente tratada, por exemplo, na Tetralogia II sobre relação

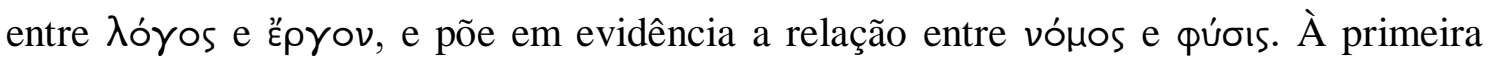
vista desempenharão um papel relativamente menor nessa Tetralogia, mas nos parece interessante notar o modo como Antifonte aborda esses assuntos que, ao que parece, foram bastante discutidos no período.

\subsubsection{A relação entre $\lambda o ́ \gamma o s$ e épyov}

Em primeiro lugar, em uma breve passagem do segundo discurso da acusação, Antifonte, de modo similar ao ocorrido na Tetralogia II, parece insinuar, em algum

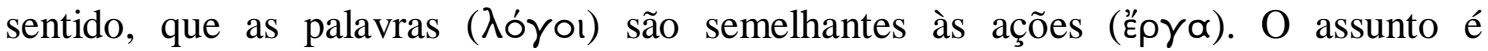
recuperado da seguinte maneira:

"Não me surpreende que o acusado, após ter praticado atos ímpios, faça

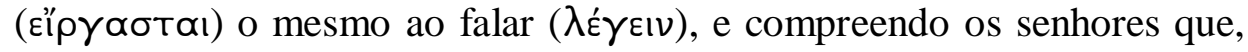

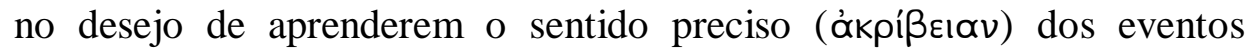
realizados, tolerem ouvir dele tais palavras, que são dignas de repúdio." (4.3.1)

Como ocorre com os litigantes na Tetralogia precedente, a acusação parece

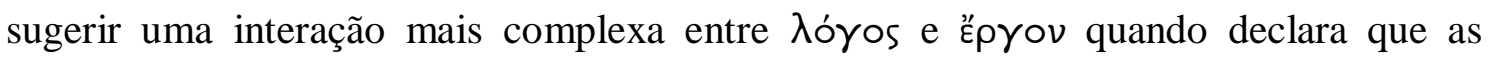
palavras do réu, dignas de repúdio, coincidem com suas ações ímpias, ou seja, que sua conduta e sua palavra não são contrastantes. Ela observa ainda a necessidade dos juízes

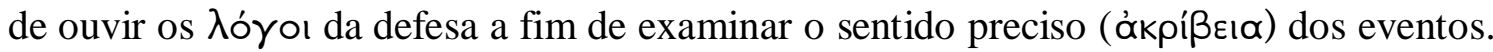

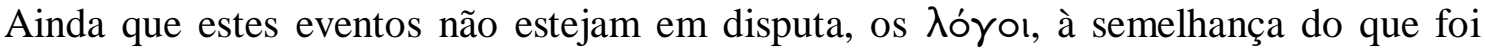


declarado pela defesa na Tetralogia II (3.4.1-2), são necessários para se chegar à verdade dos fatos.

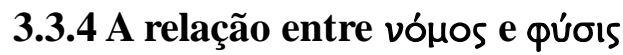

Já sobre a relação entre vónos e qúoıs, ela parece ter sido outro tópico importante do pensamento e dos argumentos da segunda metade do século $\mathrm{V}$ a.C. Em linhas gerais, o termo vónos é tradicionalmente traduzido por "lei" ou "costume" ou “convenção", embora seja mais sutil do que isso; já o termo qúoıs é traduzido de modo geral por "natureza", sentido este que remete aos filósofos geralmente designados por Pré-Socráticos, que o usavam para descrever a natureza das coisas ou a totalidade da realidade, e que em um determinado momento passou a ser usado para se referir, entre outras coisas, à "natureza humana". É difícil, contudo, saber quando e como surgiu a antítese entre vómos e qúoıs. Ainda que pareça ter sido de grande interesse para vários pensadores que foram denominados sofistas, não haveria evidências de que teria surgido com eles. Martin Ostwald ${ }^{499}$, por exemplo, em From Popular Sovereignty to the Sovereignty of Law (1987), diz que o tratado hipocrático Ar, água, lugares, composto por volta de 430 a.C., contém a mais antiga justaposição entre vómos e qúoıs que chegou até nós. Nesse tratado, segundo Ostwald, não haveria uma antítese entre os termos, mas uma complementação. Ele sugere que a primeira ocorrência, dos textos que chegaram até nós, da relação antitética vómos/ púoıs seria encontrada nas Nuvens de Aristófanes (vv. 1075-1078), de 423 a.C. ${ }^{500}$, em uma peça de um comediógrafo que, de algum modo, trata de questões contemporâneas ${ }^{501}$. Nesse texto, o vómos já é encontrado representando um contra-valor à qúoıs enquanto norma social e política. E será do ponto de vista moral e político que essa antítese será comumente invocada na segunda metade do século $\mathrm{V}$ e no século IV a.C.

Os retratos platônicos de Protágoras e Hípias, no Protágoras (320c-323c) e (337c6-e2), de Trasímaco, na República (338c1-2) e de Cálicles, no Górgias (482c4-486

\footnotetext{
${ }^{499}$ OSTWALD, 1987, p. 261

${ }^{500}$ Ibid., p. 261

501 Guthrie, por sua vez, apoiando-se no artigo de Pohlenz (Nomos und Physis, Hermes, 1953, pp. 418-38) sugere que a afirmação segundo a qual "o justo e o injusto não o são por фúఠєl, mas por vó $\mu \omega$ " (A 1 e 2 DK) atribuída a Arquelau (século V a.C.), contemporâneo de Demócrito, "é provavelmente anterior, e em todo caso é a única menção conhecida dela [da contraposição vómos/申úøıs] em contexto ético" (GUTHRIE, 1991, p. 60).
} 
d1), como pensadores para quem a relação entre vómos e qúoıs foi a principal preocupação, pode não dizer muita coisa sobre o que significou realmente esse assunto para esses autores. É difícil saber até que ponto o retrato platônico representou o pensamento concreto dessas personagens históricas, mas as teses atribuídas a elas são, de uma forma ou de outra, críticas dos vóno tradicionais e valorizadoras da qúoıs. No mais, o assunto também teria sido desenvolvido por outros autores do período como é o caso de Tucídides na História da guerra do Peloponeso (livros 3 e 4), ou poderia ser encontrado em textos como o tratado chamado Anonymus Iamblichi (DK 89), talvez do século V ou IV a.C., em que se faz uma defesa mais explícita das reivindicações do vónos, "ou lei convencional, e moralidade, contra os que pretendiam depor vónos em

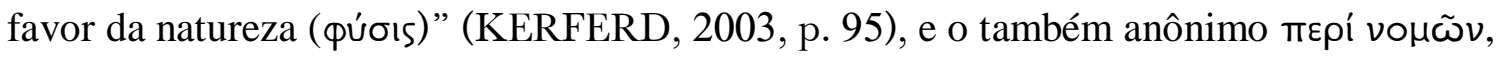
em que os vónoı "são o produto de um tipo de acordo contratual".

Entretanto, a abordagem de Antifonte em Sobre a Verdade, composto por volta de 420 a.C., é considerada a investigação mais elaborada que sobreviveu do século V a.C. sobre vónos e qúors. Nesse texto, o autor, talvez o mesmo das Tetralogias, aparentemente advoga obediência às necessidades da natureza humana (фúoı) em contraposição às leis (vómoı). Mas, como nota Kerferd, e como já mencionado em 1.1, é difícil saber se Antifonte está declarando a sua própria opinião ou apresentando um problema que ele se propõe examinar, como o próprio autor diz em uma passagem: "é por causa de todas essas coisas que fazemos o exame dessas coisas" (44a, coluna 2, linha 24) ${ }^{502}$. Apesar de o caráter fragmentário do Sobre a Verdade dificultar maiores conclusões, a sutil discussão sobre a oposição entre vómos e 申úoıs, nas palavas de Kerferd, é "extremamente valiosa por nos dar um vislumbre da maneira como esses temas podiam ser discutidos no período sofista" (Ibid., p. 197).

Nesse contexto, a relevância da Tetralogia III, se os discursos foram realmente compostos por volta de 430 a.C., está no fato de seu autor trabalhar um tema em discussão na época, sendo este texto mais um dos que chegaram até nós a documentar esse assunto, visto que nele parece haver, em uma passagem, uma complementação entre vómos e qúoıs, e, em outra passagem, uma antítese.

A primeira se encontra logo no início da Tetralogia III e é introduzida da seguinte forma:

${ }^{502}$ Tradução minha. 


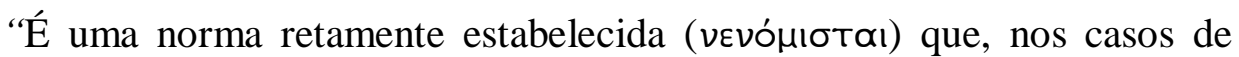
homicídio, os acusadores se esforcem bastante para fazer a acusação e testemunhar conforme a justiça, não deixando escapar os responsáveis, nem levando ao tribunal os inocentes". (4.1.1)

Embora não utilize o termo vómos, Antifonte começa o discurso com um termo

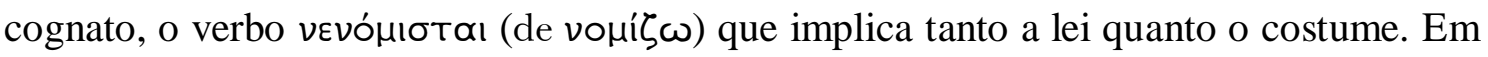
outras palavras, é estabelecido pelo vómos que, nos casos de homicídio, o assassino seja punido. A punição é necessária pois:

“(...), o deus (ö Өદós), desejando criar a raça ( $(\bar{u} \lambda \circ v)$ humana, gerou (ह้фvoєv) os primeiros de nós e, como alimento nos deu a terra e o mar, para que não morrêssemos antes pela falta das coisas necessárias do que pelo fim oriundo da velhice" $(4.1 .2)^{503}$.

Após mencionar que o vópos estabelece que nos casos de assassinato o responsável deve ser punido, Antifonte introduz na fala da acusação um breve mito sobre a origem da humanidade (e, como se verá, da legalidade, mais precisamente da origem das leis de homicídio). Embora o termo qúoıs não apareça nessa passagem, duas palavras cognatas são usadas para descrever a criação da raça humana - фũ $\lambda \circ \nu$ e É - e essa descrição indica que a criação divina é parte de nossa natureza.

A acusação, então, reforça a conexão entre os aspectos humanos e divinos, bem como a fundamentação religiosa das leis de homicídio quando declara que um assassinato é uma ofensa contra os deuses:

"Pois, uma vez que a nossa vida foi tão estimada pelo deus, aquele que mata alguém ilegalmente (óvó $\mu \omega s$ ), comete impiedade contra os deuses

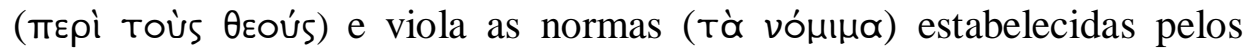
homens". (4.1.2)

De acordo com essa passagem, que aparentemente reflete uma crença religiosa, os seres humanos são criações divinas; se o deus criou os homens, assassinar alguém

\footnotetext{
${ }^{503}$ Essa passagem nos remete ao mito da criação humana contado pelo personagem Protágoras no diálogo homônimo de Platão (Protágoras, 320c-323c), apesar de não haver pontos em comum. No mito colocado na boca da acusação na Tetralogia III, não é explicado, por exemplo, onde a divindade fez nascer os homens; e é mencionado que para se alimentarem foi dado a eles a terra e o mar. No mito colocado na boca do Protágoras platônico, os humanos foram levados da terra para a luz (321c) - as criaturas mortais foram plasmadas pelos deuses nas entranhas da terra, da mistura do ferro e do fogo; e descobrem os alimentos por eles mesmos ("Não demorou, e começaram (...) a procurar na terra os alimentos", 322c).
} 


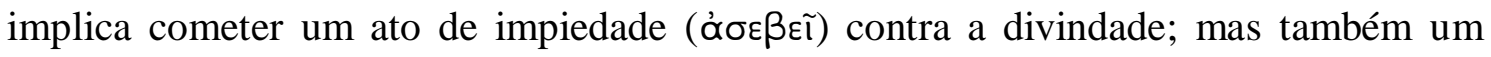
assassinato implica violar ( boca do acusador sugere que as leis de homicídio têm o respaldo dos deuses, pois o homicídio - de qualquer tipo - é uma violação da nossa natureza ( criação divina. Naturalmente, desobedecer essas leis é desobedecer aos deuses. Mas, por outro lado, significa também desobedecer às normas ( $\nu$ ó $\mu \mu \alpha)$ estabelecidas pelos homens. Com efeito, assassinar alguém ớvó $\mu \omega s$ significa transgredir duas esferas: a divina e a humana. É interessante notar que as leis de homicídio, não apenas nesses discursos hipotéticos, mas também nos discursos de tribunal de Antifonte, não são tratadas como leis quaisquer. $\mathrm{O}$ autor acena, mais de uma vez, para o caráter distintivo e sagrado - dessas leis. Em Sobre o Coreuta (6.2), por exemplo, são tratadas como "as mais belas de todas as leis e as mais sagradas", "as mais antigas nesta terra" e caracterizadas pela inalterabilidade que, para o orador, seria um indício de que foram bem feitas. Em Sobre o Assassinato de Herodes (5.14-15), repete-se que "são as mais belas de todas as leis e as mais sagradas"; que são "as mais antigas nesta terra"; que não são alteradas, indício, segundo o orador, de que são leis bem instituídas e "que ninguém jamais ousou alterar" ${ }^{204}$.

Após afirmar, então, que o assassinato, do ponto de vista religioso, é um ato de impiedade, e, do ponto de vista jurídico, é uma violação da norma estabelecida pelos homens, o acusador introduz a tese, baseada nessa crença religiosa, de que aquele que acusa a pessoa errada traz para si um miasma:

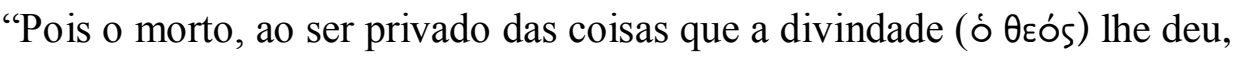
naturalmente deixa para trás, como instrumento da punição divina, os espíritos infernais hostis, que os que julgam e os que testemunham injustamente, sendo cúmplices da impiedade do assassino

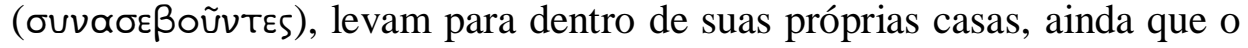

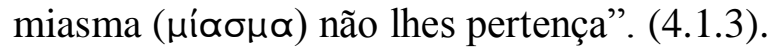

Ou seja, em casos envolvendo crime de sangue, a vingança divina se manifesta através dos espíritos infernais, originados do morto. Aqueles que julgam ou testemunham injustamente se tornam partícipes da impiedade do assassino e espalham a contaminação sobre a cidade.

${ }^{504}$ Traduções minhas. 
Uma explicação plausível para esse proêmio parece ser a de que, na visão do acusador, aquele que comete um assassinato viola, por um lado, a natureza humana, ofendendo a divindade por esse ato de impiedade, pois o ser humano é sua criação; e, por outro lado, as leis de homicídio conservadas pelos homens. A associação entre vónos e qúois ou a imagem do vónos e da qúors se complementando, operando conjuntamente, pode ser observada precisamente na tese segundo a qual o homicídio

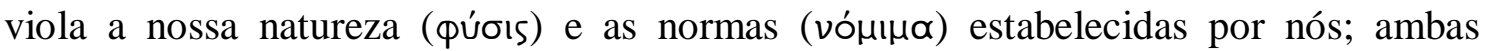
contam com um componente divino; e, o principal, tanto os vómo dos homens (no caso,

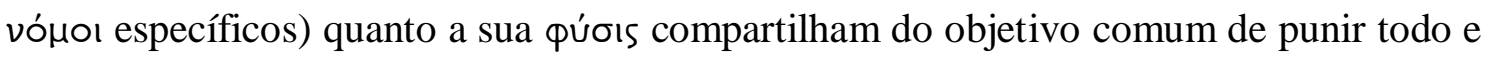
qualquer assassino ${ }^{505}$.

A Tetralogia III não fornece explicitamente nenhuma informação nesse mito, a exemplo daquele apresentado pelo Protágoras platônico, de que os deuses deram aos

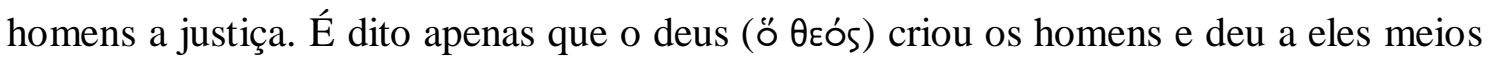
para sobreviverem. Entretanto, uma lei que proíbe absolutamente qualquer um assassinar outro homem parece estar implícita no mito apresentado pela acusação. Nesse proêmio, Antifonte claramente constrói a fala da acusação a partir de um raciocínio baseado em uma crença religiosa, que pretende ter valor absoluto, em que o assassinato deve ser proibido por se tratar de um ato de impiedade e, portanto, uma ofensa contra os deuses. A elaboração desse cenário talvez possa ter interessado a Antifonte pelo fato de permitir a ele ilustrar um confronto entre essa lei respaldada pelos deuses que proíbe qualquer assassinato e o sistema legal ateniense do período, que estipulava situações específicas em que uma pessoa podia assassinar outra. Independentemente disso, é interessante notar que, diante desse quadro fornecido pela acusação, o argumento da defesa consistirá em reforçar a sua completa inocência, tentando rebater a acusação mencionando exatamente uma lei (vómos) que proíbe assassinar justa ou injustamente (4.2.3 e 4.4.8). Ela faz isso recorrendo a uma figura de linguagem chamada проката́ $\lambda \eta \psi i s$, uma estratégia que consiste em antecipar uns dos argumentos do oponente:

"Bem, responderá ele: 'Mas a lei (vómos) que proíbe matar justa e injustamente, mostra que você está sujeito às penas do homicídio, pois o homem está morto'. Mas eu afirmo pela segunda e pela terceira vez que não matei, (...)". (4.2.3)

${ }^{505}$ GAGARIN, 2002, pp. 127-8. 
Ainda que possa estar implícito, o acusador em momento algum declara essa lei nesses termos. Isso é referido apenas pela defesa, que insiste na tese de ter desferido os golpes na vítima, mas não ter matado. Parece curioso que a defesa mencione por duas vezes essa lei que proíbe qualquer um de assassinar, a fim de rebater com argumentos o discurso da acusação. A defesa parece estar ciente do peso desse argumento apoiado em uma lei fundamentada em uma crença religiosa tratada como uma lei universal da natureza, de tal modo a não se ater tanto aos pressupostos jurídicos, mas a empregar, ainda em seu primeiro discurso (4.2.7), os termos comuns à acusação, dizendo que é inocente e alertando que se o acusado for privado da vida dada pela divindade, será

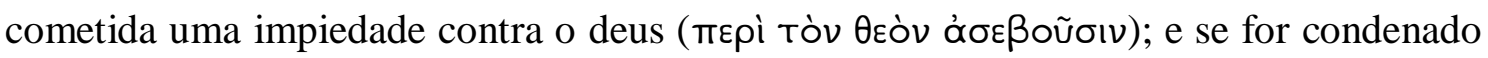

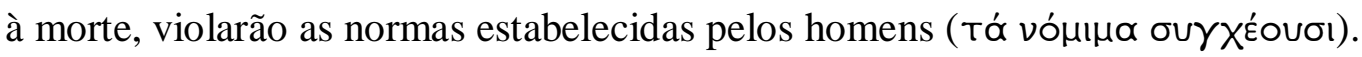

Além dessa passagem, alguns comentadores entendem que uma outra também possa sugerir uma complementação entre vónos e qúoıs e não uma antítese. Ela estaria presente no segundo discurso da defesa, quando ela declara que "as maiores penalidades

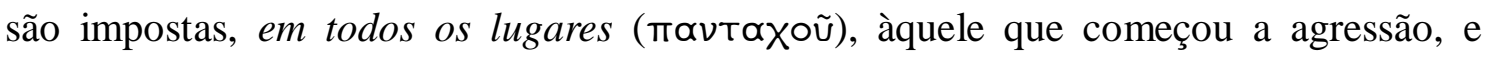
nenhuma penalidade, em lugar nenhum, é escrita para aquele que se defende" (4.4.7). A observação feita, por exemplo, por Gagarin ${ }^{506}$ para essa passagem é a de que se as

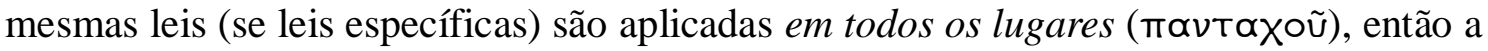

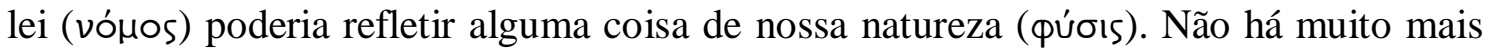
informação além dessa passagem, mas, ao se referir à penalidade escrita (ĖTıtíuıa

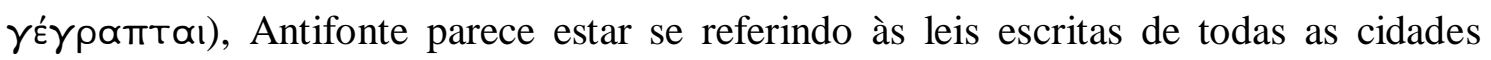
gregas e não a uma lei não-escrita universal, comum a todos os povos, comuns aos gregos e também aos bárbaros. Vale lembrar que a defesa, aqui, não está se referindo a um homicídio, mas a uma situação específica em que um inicia a agressão e o outro se defende, e o argumento dela em todo o discurso é o de que ela se defendeu de uma agressão. Afirmação semelhante é feita pela defesa em Sobre o assassinato de Herodes quando diz que a norma que permite ao acusado partir para o exílio antes de seu segundo discurso, como ocorre na Tetralogia III, "é um direito comum a todos" (ärmaoı

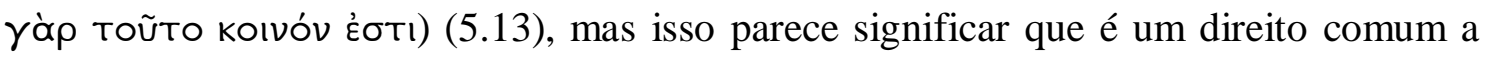

506 GAGARIN, 2002, p. 132. 
todos os gregos e não a todos os povos; logo, não estaria se referindo a uma lei universal.

A leitura feita por Decleva-Caizi ${ }^{507}$ dessa passagem, por sua vez, é a de que o uso do advérbio па que lhe beneficiaria (uma que pune o que começa uma agressão, não havendo nenhuma que pune aquele que se defende) a uma lei aplicada universalmente, como a insinuada (mas não proferida) pela acusação em seus discursos: aquela que veta qualquer um de cometer um assassinato de qualquer tipo. Ainda que essa passagem não possa ser citada como um caso em que vónos e qúoıs são complementares, sabemos que pensadores do período se interessaram pelas diferenças entre os vómo de diferentes povos, caso de Heródoto (História, 3.38), que apontou as diferenças entre os costumes dos gregos e os dos indianos. Kerferd, por exemplo, lembra o segundo capítulo do Dissoi Logoi, em que são usadas oposições entre os costumes dos diferentes povos (KERFERD, 2003, p. 192). E mesmo Antifonte, no Sobre a Verdade (44b), teria tratado dessa questão descrevendo uma visão das leis como a retratada por Heródoto: um contraste entre os Estados que vivem próximos e aqueles que vivem distantes e que se comprometem com seus próprios vóno e sublinham a oposição com os dos povos distantes. Pela qúoıs, contudo, haveria, apesar das diferenças entre as leis e os costumes, uma similaridade entre as pessoas: o vómos, de acordo com Antifonte, no Sobre a Verdade, impôs uma oposição onde, pela థúoıs, não havia.

Já a passagem em que parece haver uma antítese e não uma complementação entre vónos e qúoıs ocorre no último discurso da defesa quando ela rebate os argumentos do eikós do discurso anterior da acusação. Se para a acusação (4.3.2) é mais plausível que os mais jovens, e não os mais velhos, comecem uma agressão, pois pertencem aos primeiros a arrogância ( $\mu \varepsilon \gamma \alpha \lambda \circ \varphi \rho \circ \sigma u ́ v \eta)$, a plenitude da força física

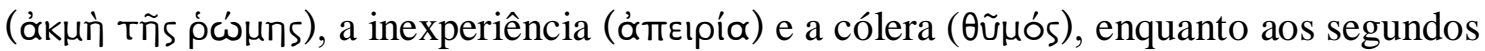

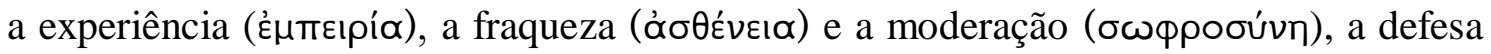
faz a distinção entre o que é plausível e o que é necessário segundo a natureza ( фúoı):

“(...) se fosse a lei da natureza (katò qúoıv) que, assim como os olhos

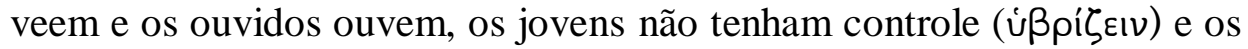
velhos sejam moderados ( $\sigma \omega \phi \rho о \nu \varepsilon i ̃ v)$, não seria necessário o julgamento

507 ANTIPHONTIS, 1969, p. 259 
dos senhores, pois a própria idade dos jovens os condenaria. Agora, sendo muitos os jovens moderados e muitos os velhos que se entregam

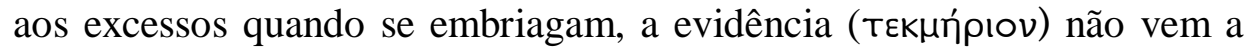
ser mais favorável ao acusador que ao acusado." (4.4.2)

A defesa parece insinuar que uma regra baseada no que é plausível não é a mesma coisa que uma regra da natureza: se fosse a lei da natureza que o jovem agisse com violência ou desmedida (üßpıs) e o velho com moderação ( $\sigma \omega \phi \rho \circ \sigma u ́ v \eta)$, como é a lei da natureza que os olhos veem e os ouvidos ouvem, então o argumento da acusação alegando que o velho não começou a briga seria válido; mas esse argumento não é válido, visto que há muitos casos em que um velho começa uma briga. Coloca-se, então, de um lado, o zíkós e, contraposto a ele, as coisas que por natureza (фúoıs) são necessárias a todos os homens. Em vista disso, essa passagem, na opinião de Gagarin ${ }^{508}$, insinua que o argumento do Eíkós pertenceria ao vónos, (ou ao costume) na medida em que um jovem costumeiramente começaria uma briga, mas não necessariamente, tal qual uma função natural do homem.

O interessante nessa discussão é observar, sobretudo, como Antifonte aborda esse assunto insinuando, em uma passagem inserida na fala da acusação, uma relação em que a púoıs fornece uma base para o vónos, e em outra, inserida na fala da defesa, uma relação antitética. Como no caso do Sobre a Verdade, em que dificilmente pode-se afirmar que o autor esteja declarando sua própria opinião, nessa Tetralogia III talvez mais importante seja perceber que a exposição desse assunto é feita em um texto provavelmente composto em um momento em que esse tópico estava sendo desenvolvido.

\subsubsection{O miasma}

Por fim, a exemplo das outras Tetralogias, outro aspecto presente nesse discurso é a questão da mancha decorrente do crime de sangue que contamina não apenas o assassino, mas pode, sobretudo, infectar os acusadores e os juízes, caso não ajam de acordo com a justiça. Ela se manifesta, pelo lado dos acusadores, quando aventado por eles que, se acusam o homem errado, terão o miasma da vítima e da defesa, no caso desta ser injustamente acusada e condenada; e, pelo lado do defensor, para alertar os

${ }^{508}$ GAGARIN, 2002, p. 132 
juízes a absolver o réu, caso contrário receberão eles mesmos o miasma. Na Tetralogia III esse assunto é trabalhado do seguinte modo:

No proêmio de seu primeiro discurso (4.1.3-5), a acusação argumenta que o

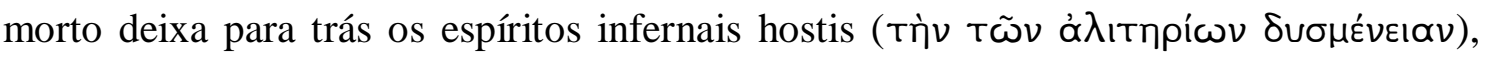
que agem como instrumentos da vingança divina uma vez que a divindade deu ao homem a vida. Aqueles que julgam e testemunham injustamente tornam-se cúmplices do assassino e levam a hostilidade dos espíritos infernais para dentro de suas casas, ainda que o miasma não lhes pertença (4.1.3). Em outras palavras, o morto suscita a ira dos espíritos infernais que se propaga sob a forma de miasma e atinge também os juízes caso cometam injustiça em seus julgamentos. Por outro lado, a acusação lembra que, se condenarem um inocente, estarão sujeitos às penas do homicídio e, se deixarem sem

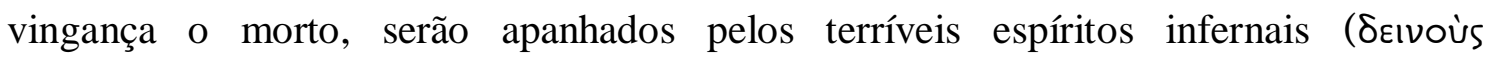
à $\lambda$ ıтnpíous) (4.1.4). Afirma, por fim, que os juízes devem punir o jovem, o verdadeiro

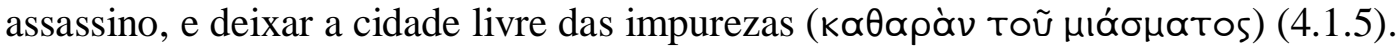

No epílogo de seu primeiro discurso (4.2.8-9), a defesa pede aos juízes que o absolvam, pois se for posto em liberdade, sendo ele culpado, o espírito vingador do

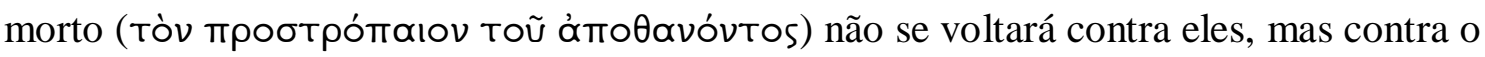
acusador que não os instruiu corretamente. Agora, se, por outro lado, ele for condenado

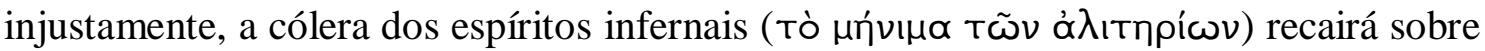
os juízes, não contra o acusador (4.2.8). Absolvendo, então, o jovem conforme a piedade e a justiça, todos os cidadãos estarão purificados (4.2.9).

No epílogo de seu último discurso (4.3.7), a acusação apela aos juízes para livrar

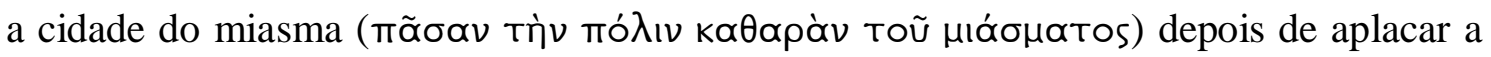

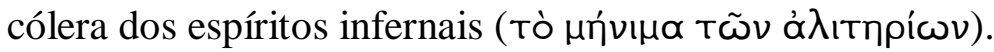

E, finalmente, no epílogo do último discurso da defesa (4.4.10), agora a cargo de um amigo do réu, que partiu para o exílio, pede-se aos juízes que não matem um inocente, caso contrário será dupla a cólera dos espíritos infernais contra seus assassinos: por não ter vingado o velho assassinado e por terem condenado à morte um inocente. Ameaça que não parece se justificar visto que, tendo o réu partido para o exílio, não seria morto; logo, não lançaria espíritos vingativos contra ninguém. 


\section{REFERÊNCIAS BIBLIOGRÁFICAS}

\section{Edições e traduções das Tetralogias:}

ANTIFONTE. Discursos y Fragmentos, Antifonte/Andócides (Introducción, traducción y notas de Jordi Redondo Sánchez), Madrid: Editorial Gredos, S. A., 1991. . Testemunhos, Fragmentos e Discursos. (Tradução de Luís Felipe Bellintani Ribeiro), São Paulo: Edições Loyola, 2008.

ANTIPHON. Minor Attic Orators I. Antiphon/Andocides. (with an English translation by K. J. Maidment, M.A), Cambridge/Massachusetts/London: Harvard University Press, 1953.

Discours. (Texte établi et traduit par Louis Gernet), Paris: Les

Belles Lettre, 1954.

. Orationes et Fragmenta, (Edidit Th. Talheim et Fr. Blass).

Stuttgart: B. G. Teubner, 1966.

. The Speeches. (Edited by Michael Gagarin), Cambridge:

Cambridge University Press, 1997.

Antiphon In. Antiphon and Andocides. (Translated by Michael Gagarin). Austin: University of Texas Press, 1998.

Antiphon In: The Older Sophists (translated by J. S. Morrison), Indianapólis/Cambridge: Hackett Publishing Company, Inc. 2001.

ANTIPHONTIS. Tetralogiae. (Edidit, transtulit, commentario, instruxit Fernanda Decleva-Caizzi), Varese/Milano: Istituto Editoriale Cisalpino, 1969.

\section{Edições e traduções de obras de outros autores antigos:}

ANTISTHENIS. Fragmenta. (Collegit Fernanda Decleva-Caizzi). Varese/ Milano: Istituto Editoriale Cisalpino, 1966.

ARISTÓTELES. Ethica Nicomachea I 13-III 8, Tratado da Virtude Moral. (Tradução, nota e comentário de Marco Zingano), São Paulo: Odysseus, 2008. . Retórica. (Introdução de Manuel Alexandre Júnior; tradução e

notas de Manuel Alexandre Júnior, Paulo Farmhouse e Abel do Nascimento Pena), Lisboa: Imprensa Nacional-Casa da Moeda, 1998.

[ARISTÓTELES] Retórica a Alexandre. (Tradução, textos adicionais e notas de Edson Bini), São Paulo: Edipro, 2012. 
ARISTOTLE. On Rhetoric - A Theory of Civic Discourse. (Translated with introducion, Notes and Appendices by George A. Kennedy), New York/Oxford: Oxford University Press, 2007.

The Athenian Constitution. (with an English translation by $\mathrm{H}$. Hackham, M. A.), London/Cambridge/Massachusetts: Harvard University Press, s. d.

[ARISTOTLE] Rhetorica ad Alexandrun. (with an English translation by $\mathrm{H}$. Hackham, M. A.), London/Cambridge/Massachusetts: Harvard University Press, 1957.

GORGIAS. Die Fragmente der Vorsokratiker Griechisch und Deutsch, (von Hermann Diels, Aufklage herausgegeben von Walther Kranz). Berlin: Weidmannsche Verlagsbuchhandlung, 1956, Vol. II, pp. 271-307.

HINOS HOMÉRICOS. Hino a Hermes (Tradução, Notas e Estudo de Maria Celeste C. Dezotti), São Paulo: Editora Unesp, 2010.

HERODOTUS. Histories, Vol 1. Book 1 and 2. (with an English translation by A.D. Godley) London/Cambridge/Massachusetts: Harvard University Press, 1975.

PLATÃO. As Leis. (Tradução, Notas e Introdução de Edson Bini), São Paulo: Edipro, 1999.

THUCYDIDES. History of the Peloponnesian War - Book I. (with an English translation by Charles Foster Smith), London/Cambridge/Massachussets: Harvard University Press, 1956.

TUCÍDIDES. História da Guerra do Peloponeso. (Tradução de Mario da Gama Kury). Brasília: Universidade de Brasília, 1987.

XENOPHON. Memorabilia. (with an English translation by E. C. Marchant), London/ Cambridge/ Massachusetts: Harvard University Press, 1997.

\section{Estudos críticos:}

ALLEN, D. Antiphon. The Classical Review., New Series, Vol. 54, No. 2, 2004, pp. 310-312.

BENDLIN, A Purity and Pollution. In. The Blacwell Companion to Greek Religion. (Edited by Daniel Ogden), London: Blacwell Publishing Ltd, 2007, pp. 178189

BOEGEHOLD, A. The Lawcourts of Athens - Sites, Buildings, Equipament, Procedure and Testimonia. New Jersey: The American School of Classical Studies at Athens, 1997. 
BRAUW, M. de. The parts of the speech. In: A Companion to greek rhetoric. (Edited by Ian Worthington). London: Blackwell Publishing Ltd, 2007, pp. 187-202.

CARAWAN, E. The Tetralogies and the Athenian homicide trials. The American Journal of Philology, vol. 114, no. 2, 1993, pp. 235-270. . Rhetoric and the Law of Draco. Oxford: Clarendon Press, 1998.

CAREY, C. A Note on Torture in Athenian Homicide Cases. Historia: Zeitschrift für Alte Geschichte Bd. 37, H.2, 1988. pp. 241-245. Trials From Classical Athens. London/New York: Routledge, 2001.

CARTER, M. Stasis and Kairos: Principles of Social Construction in Classical Rhetoric. Rhetoric Review, Vol. 7, No. 1, 1988, pp. 97-112. . Trials from Classical Athens. New York: Taylor \& Francis e-library, 2001.

CASSIN, B. L'Effet Sophistique. Paris: Gallimard, 1995.

COLE, T. The origins of rhetoric in ancient Greece. Baltimore: The Johns Hopkins University Pres, 1991.

. Who is Corax? In: The Attic Orators. (Edited by Edwin Carawan), New York: Oxford University Press, 2007, pp. 37-59.

CUCUEL, C. Essai sur la Langue et le Style de l'Orateur Antiphon. Paris: Ernest Leroux, 1886.

DENNISTON, J. D. Greek Prose Style. Oxford: Oxford University Press, 1952.

DOBBSON, J. F. The Greek Orators. Anne Mahoney. (Edited for Perseus). Methen and Co. London, 1919.

DOVER, K. J. The Chronology of Antiphon's Speeches. The Classical Quaterly, vol. 44 , no. $1 / 2$, 1950 , pp. 44-60.

EDWARDS, M. J. Antiphon and the Beginning of Athenian Literary Oratory. Rhetorica: A Journal of the History of Rhetoric, Vol. 18, No. 3, 2000, pp. 227-242.

FAULKNER, A. Modern Scholarship on the Homeric Hymns: Foundational Issues, In. The Homeric Hymns. Interpretative Essays. (Edited by Andrew Faulkner) Oxford/New York: Oxford University Press, 2011, pp. 1-25

FINLEY, J. H. Jr. Three Essays on Thucydides. Cambridge: Cambridge University Press, 1967.

GAGARIN, M.; COHEN, D. The Cambridge companion to ancient greek law. New York: Cambridge University Press, 2005. 
GAGARIN, M., WOODRUFF, P. Early Greek Political Thought from Homer to the sophists. Cambridge: Cambridge University Press, 1995.

GAGARIN, M. Drakon and early Athenian homicide law. London: Yale University Press, 1981. . Early Greek Law. Berkeley: University of California Press, 1986. . The Nature of proofs in Antiphon. Classical Philology, vol. 85, no. 1,1990 , pp. 22-32. Probability and Persuasion: Plato and early Greek rhetoric. In: Persuasion: Greek Rhetoric in Action (Edited by Ian Worthington), London/New York: Routledge, 1994. . The Torture of slaves in Athenian law. Classical Philology, vol. 91, no. 1, 1996, pp. 1-18. . Antiphon, The Athenian. Oratory, Law, and Justice in the Age of the Sophists. Austin: University of Texas Press, 2002. Did the sophists aim to persuade? Rhetorica: A Journal of the History of Rhetoric, vol. 19, no. 3, 2001, pp. 275-291.

. Background and Origins: Oratory and Rhetoric before the Sophists In: A Companion to greek rhetoric. (Edited by Ian Worthington). London: Blackwell Publishing Ltd, 2007, pp. 28-36 . Speeches from Athenian Law. Austin: University of Texas Press, 2011.

GOEBEL, G. H. Probability in the Earliest Rhetorical Theory. Mnemosyne, Fourth series, vol. 42, Fasc. 1/2, 1989, pp. 41-53.

GUTHRIE, W. K. C. Os Sofistas. (Tradução de João Rezende Costa). São Paulo: Paulus, 1995.

HARRISON, A. R. W. The Law of Athens Vol. 2 - Procedure. London: Oxford at the Clarence Press, 1971.

HOFFMAN, D. C. Concerning eikos: social expectation and verisimilitude in early attic rhetoric. Rhetorica: A Journal of the History of Rhetoric, vol. 26, no. 1, 2008, pp. 1-29.

JEBB, R. C. The Attic Orators from Antiphon to Isaeos. Vol.1 London/New York: Macmillan and CO., 1893. 
KELLS, J. H. Homicide law. The Classical Review, New series, vol. 15, no. 2, 1965, pp. 205-207.

KENNEDY, G. A. The Art of Persuasion in Greece. New Jersey: Princeton University Press, 1963.

Classical Rhetoric an Its Christian and Secular Tradition from Ancient to Modern Times. North Carolina: The University of North Carolina Press, 1980.

KERFERD, G. B. O movimento Sofista. (Tradução de Margarida Oliva). São Paulo: Edições Loyola, 2003.

KIRK, G.S., RAVEN, J.E., SCHOFIELD, M. Os Filósofos Pré-Socráticos. (Tradução de Carlos Alberto Louro Fonseca). Lisboa: Fundação Calouste Gulbenkian, 1994.

LOOMIS, W.T. The Nature of Premeditation in Athenian Homicide Law. The Journal of Hellenic Studies, Vol. 92, 1972, pp. 86-95.

LLOYD, G.E.R. Magic, Reason and Experience. Studies in the origins and development of Greek Science. London/Indianapólis/Cambridge: Hackett Publishing Company, Inc., 1999.

MACDOWELL, D. M. The Law in Classical Athens. New York: Cornell University Press, 1991.

OSTWALD, M. From Popular Sovereignty to the Sovereignty of Law. Law, Society, and Politcs in Fifthy-century Athens. Los Angeles: University of California Press, 1987

O' SUllivan, N. Pericles and Protagoras. Greece \& Rome, Second Series, Vol. 42, No. 1, 1995, pp. 15-23.

PARKER, R. Miasma: pollution and purification in early Greek religion. New York: Clarendon Press, 1996.

PARRY, A. M. Logos and Ergon in Thucydides. New Hampshire: Ayer Company, Publisher, INC. 1988.

RAGON, E. Grammaire Grecque. Entièrement refondue par A. Dain, J.-A. de Foucault et P. Poulain. Paris: J. De Gigord, 1961.

ROBINSON, T.M. Contrasting Arguments. An Edition of Dissoi Logoi. Salem. New Hampshire: Ayer Company, Publishers, INC. 1984. 
. The Dissoi Logoi and Early Greek Skepticism. In. Essays in Ancient Greek Philosophy VI: Before Plato. (Edited by Anthony Preus). New York: State University of New York Press, 2001.

ROMEYER-DERBEY, G. Os Sofistas. (Tradução de João Amado). Lisboa: edições 70, 1986.

ROMILLY, J. História e Razão em Tucídides. (Tradução de Tomás Rosa Bueno). Brasília: Editora Universidade de Brasília, 1998.

SCHIAPPA, E. The Beginnings of Rhetorical Theory in Classical Greece. New Haven\&London: Yale University Press, 1999.

. Protagoras and Logos. A study in Greek Philosophy and Rhetoric. Columbia: University of South Carolina Press, 2003.

SEALEY, R. The Athenian courts for homicide. Classical Philology, vol. 78, no. 4, 1983, pp. 275-296.

The Tetralogies adscribed to Antiphon. Transaction of the American Philological Association (1974-), vol. 114, 1984, pp. 71-85.

SCHMITZ, T. A. Plausibility in the Greek Orators. In The American Journal of Philology, Vol.121, No.1. 2007, pp. 47-77.

SPATHARAS, D. G. Patterns of Argumentation in Gorgias. Mnemosyne, Fourth series, vol. 54, Fasc. 4, 2001, pp. 393-408.

TOOHEY, P. Epic and Rhetoric. In. Persuasion: Greek Rhetoric in Action (Edited by Ian Worthington), London/New York: Routledge, 1994

WORTHINGTON, I. Rhetoric and Politics in Classical Greece: Rise of the Rhêtores. In. A Companion to Greek Rhetoric (Edited by Ian Worthington) London: Blacwell Publishing Ltd, 2007, pp.255-271. 